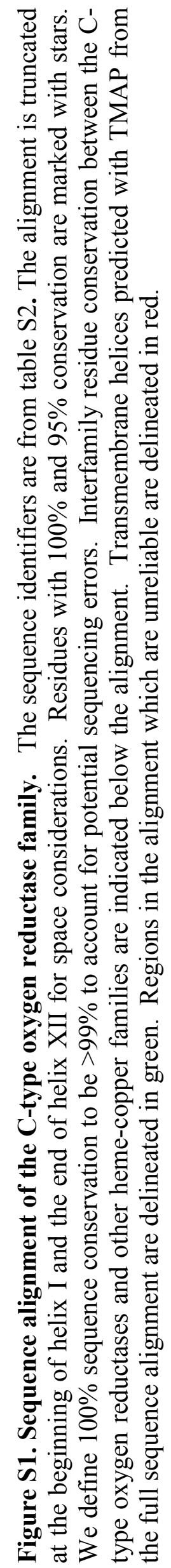

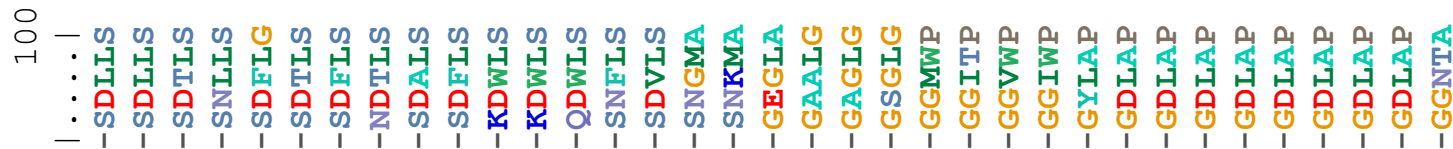

‥

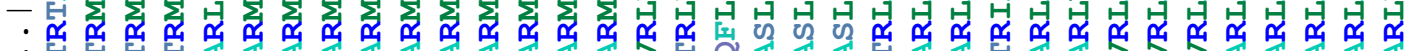

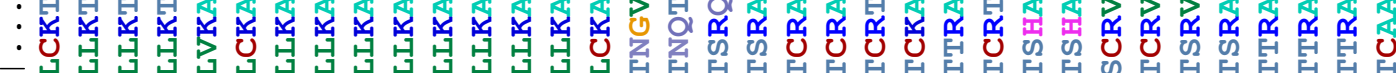

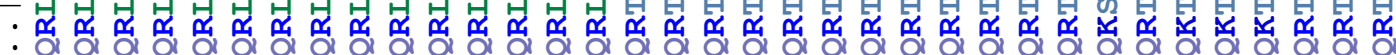
.

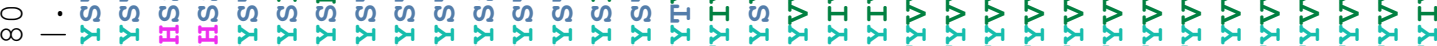
. .

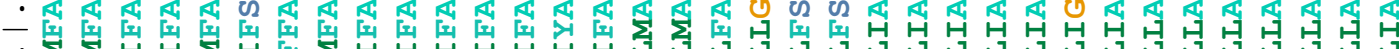

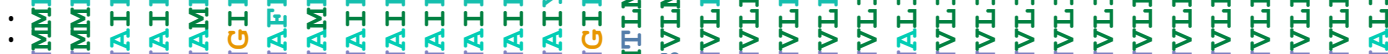

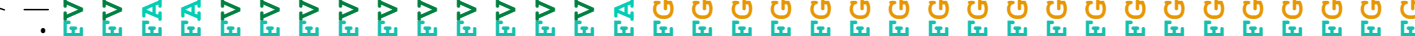
:

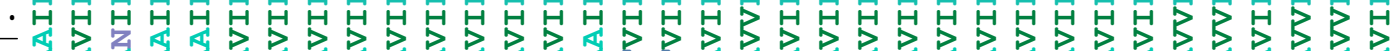

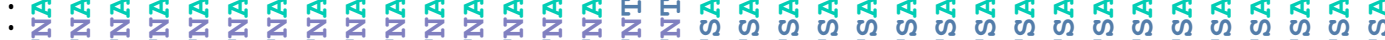

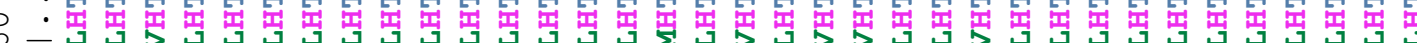

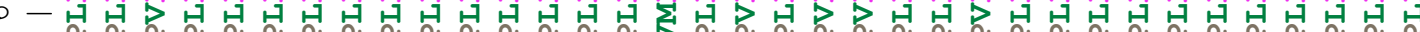

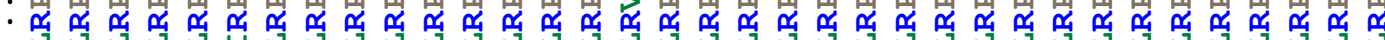

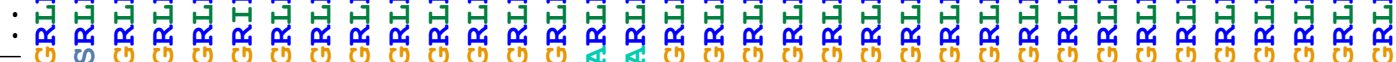

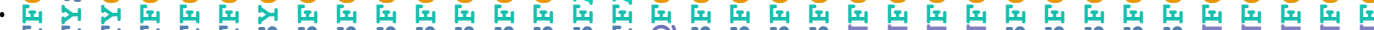

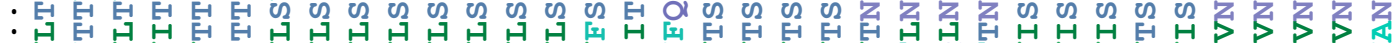

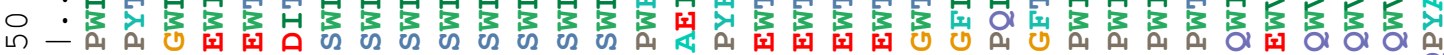

. 유:

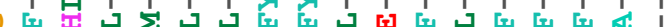

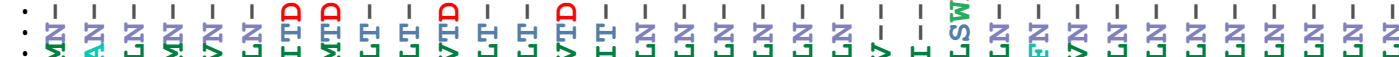

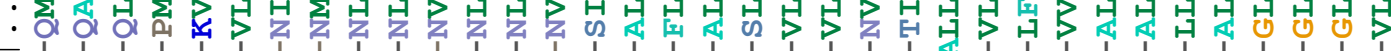
?

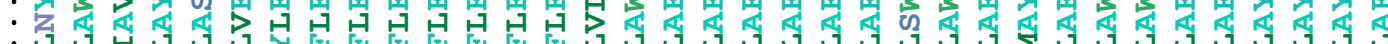

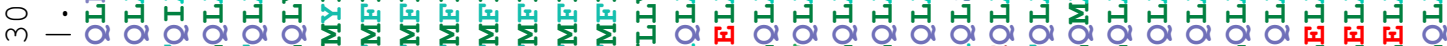
- prict

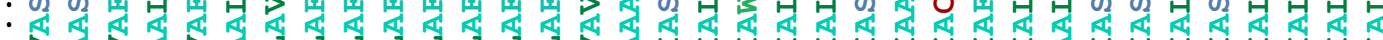

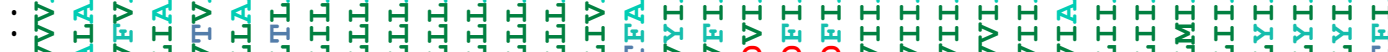
.

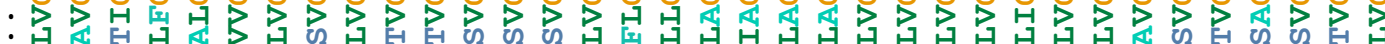

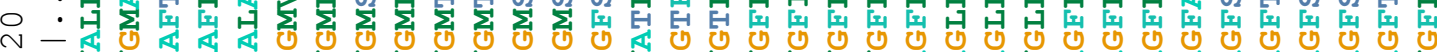

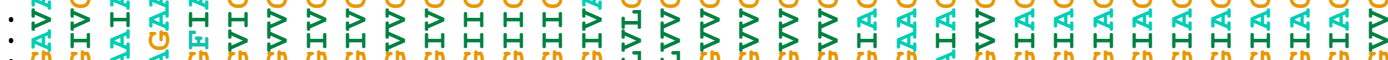
:

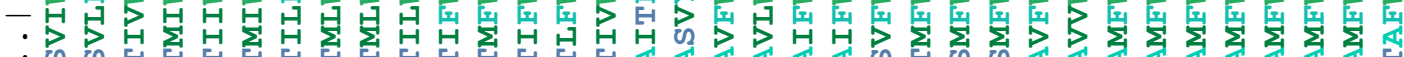
.

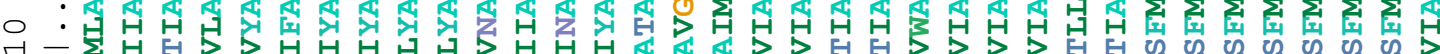
: 国

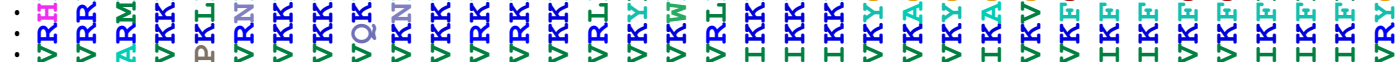

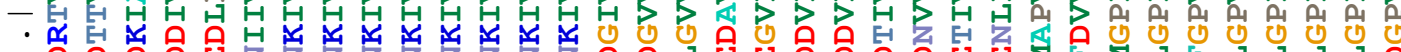

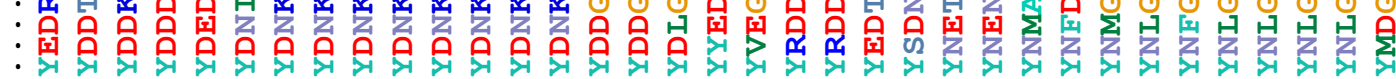

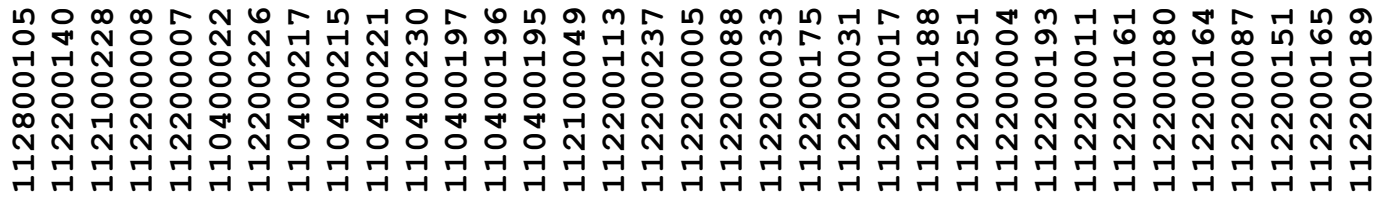




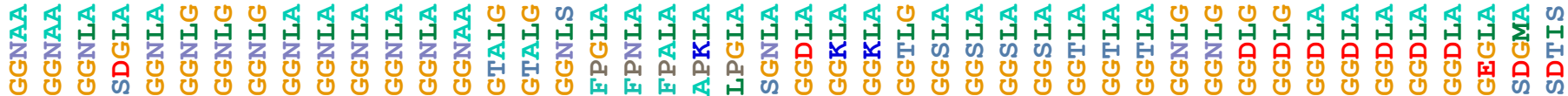

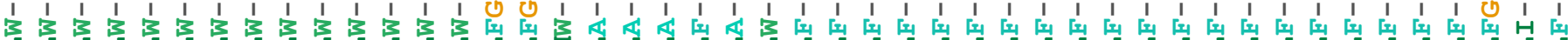

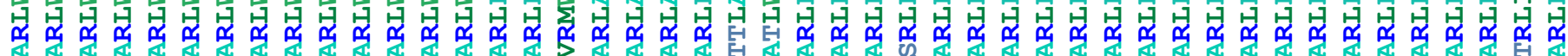

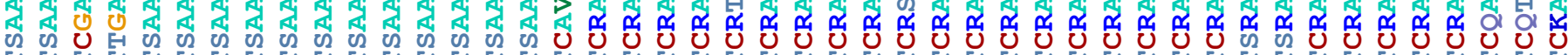

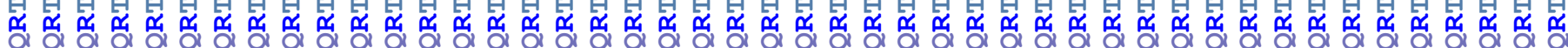

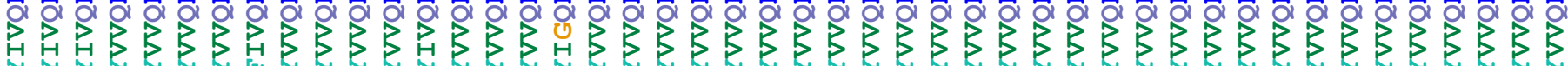

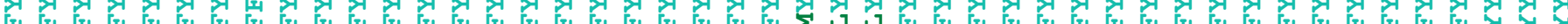

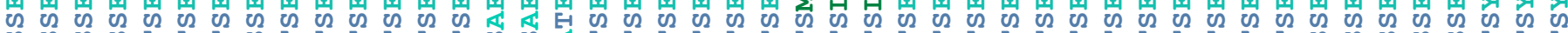

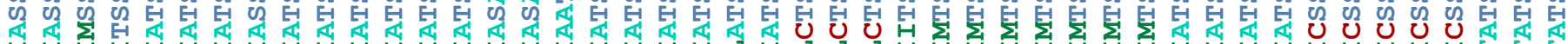

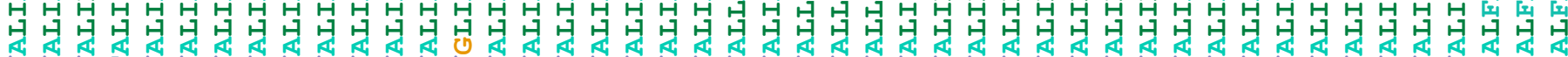

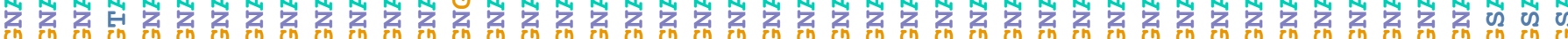

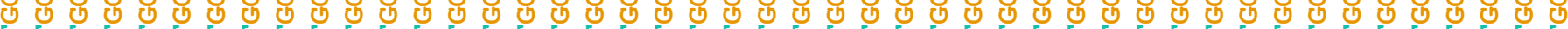

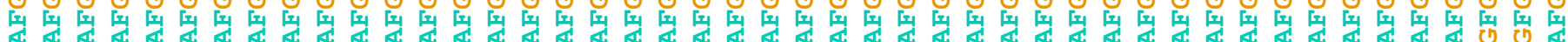

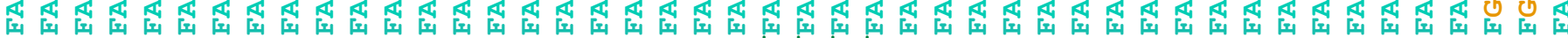

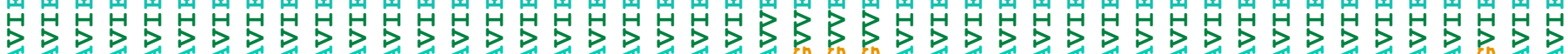
ఋ心

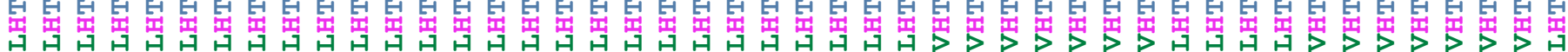

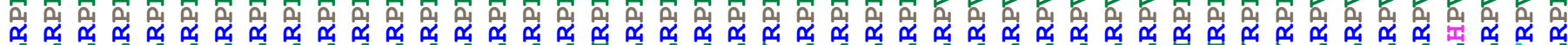

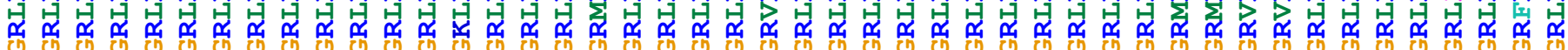

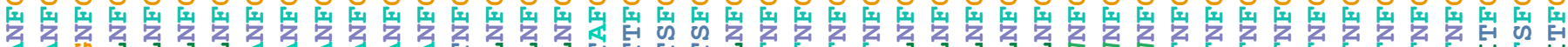

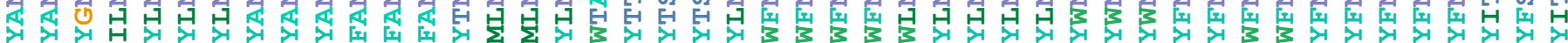

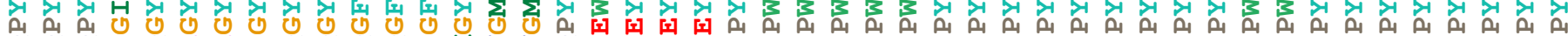

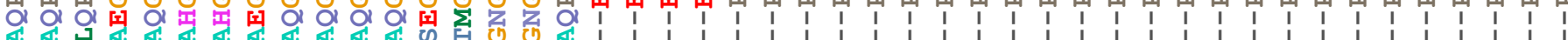

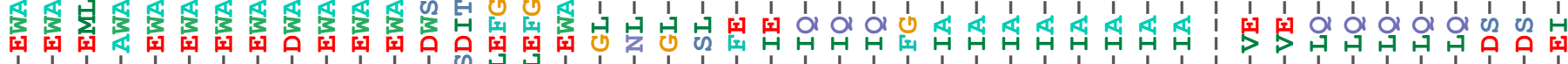

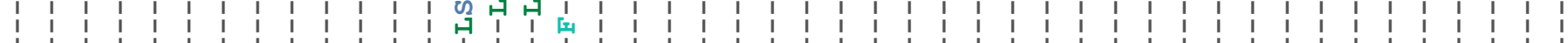

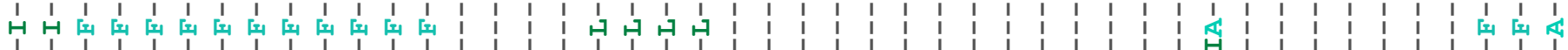

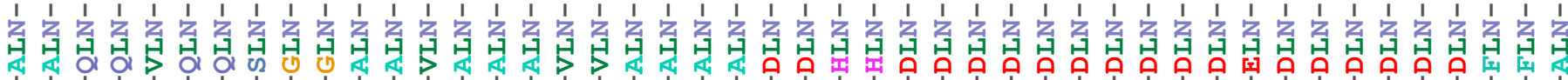

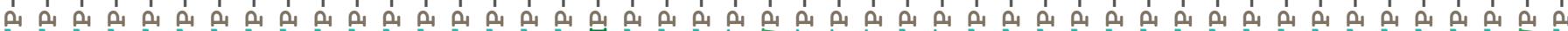

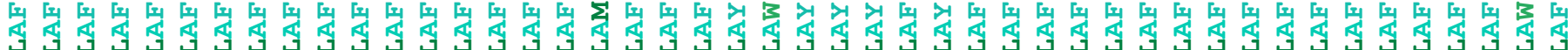

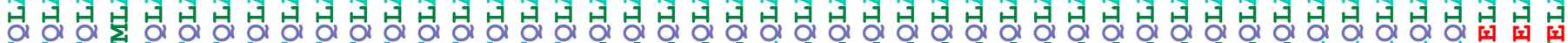

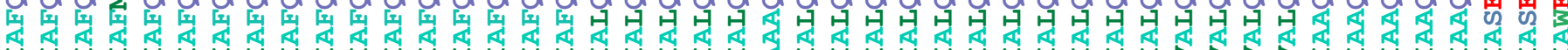
HAHAHAHAHAHAHHAHAHA

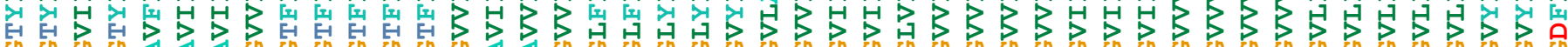

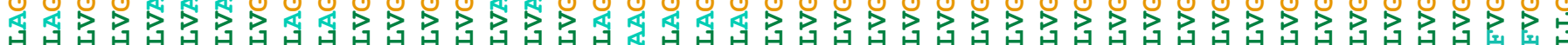

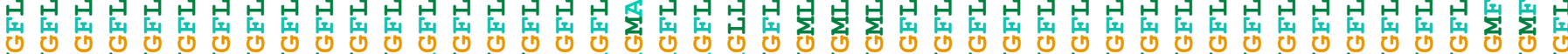

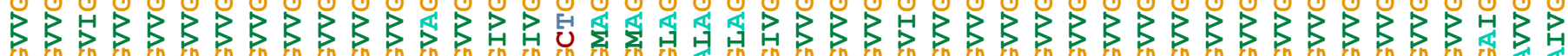

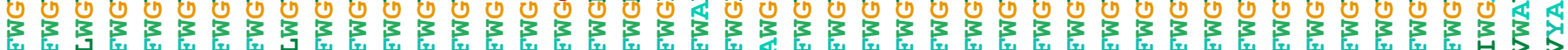

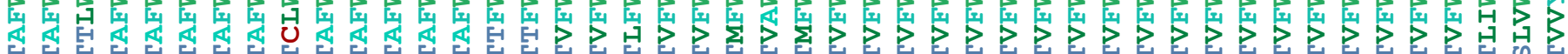

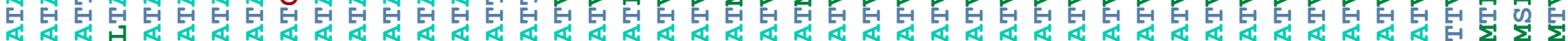

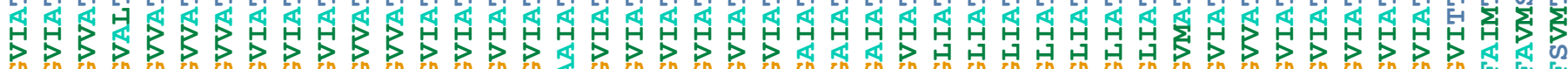

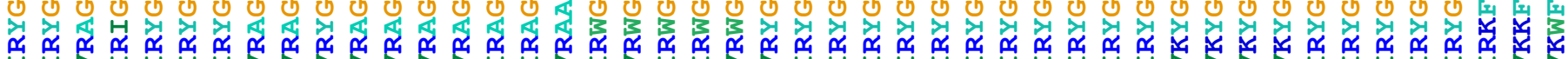

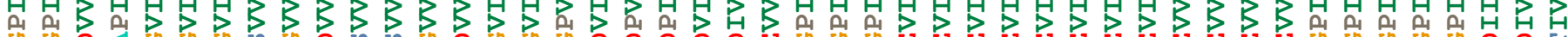

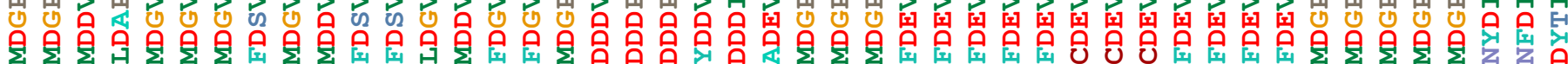

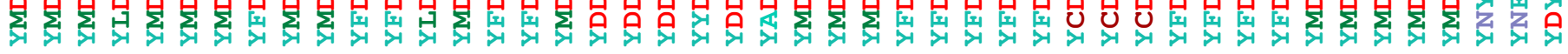

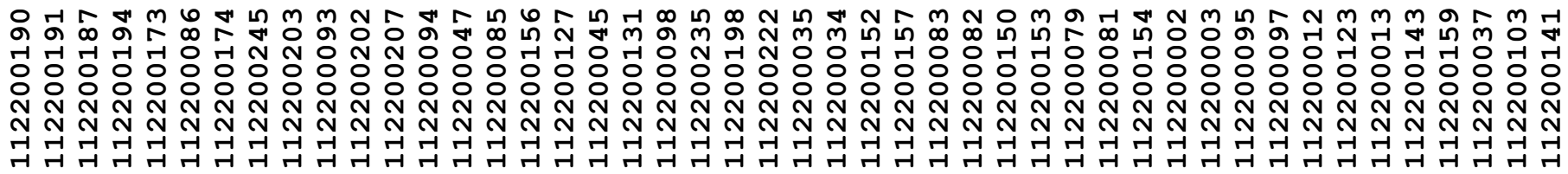




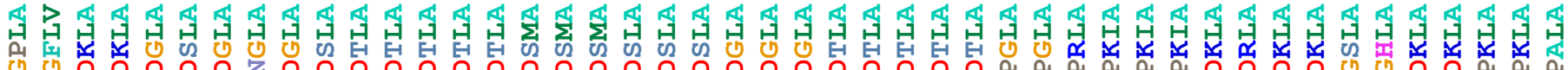

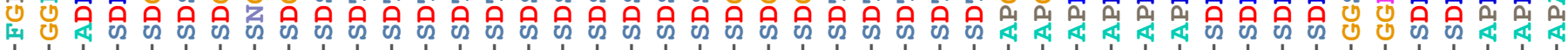

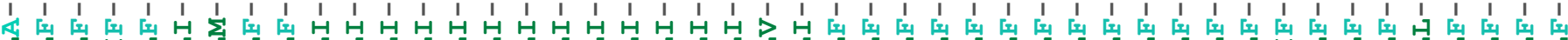

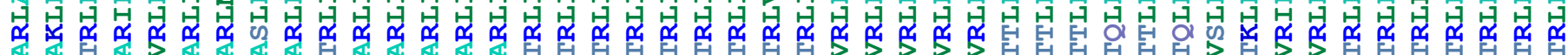

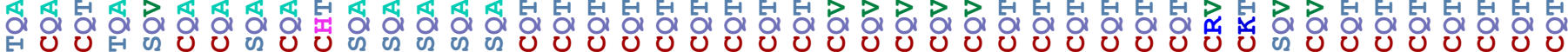

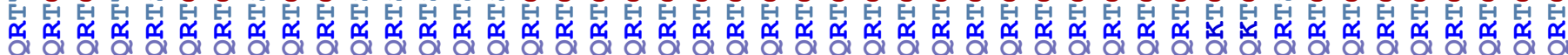

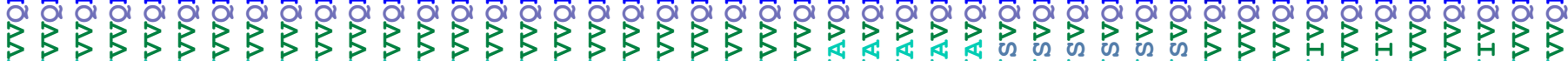

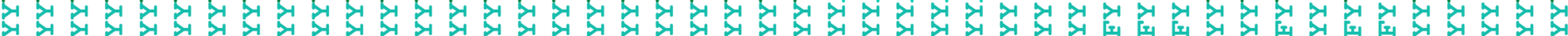

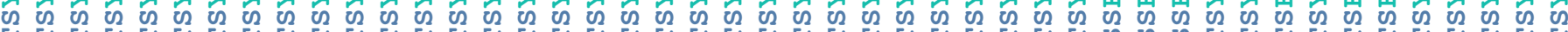

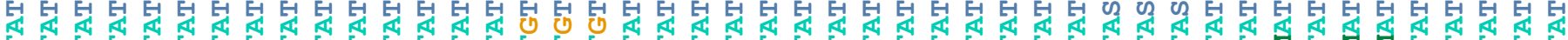

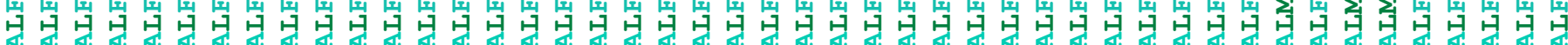
ผ

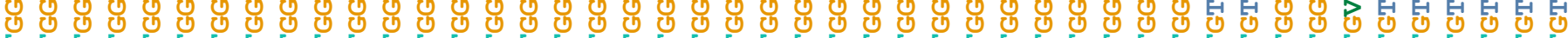

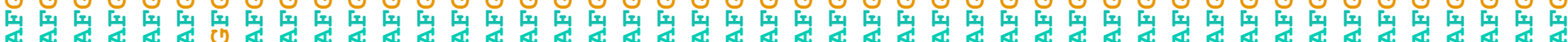
垔

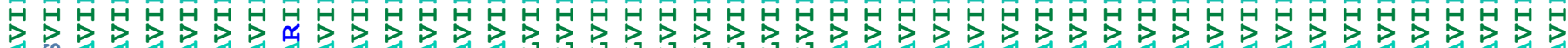

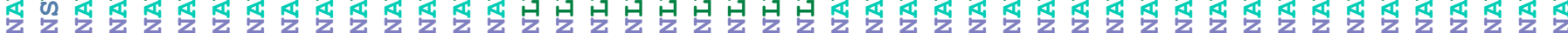

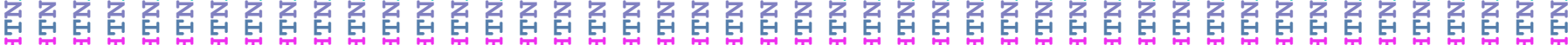

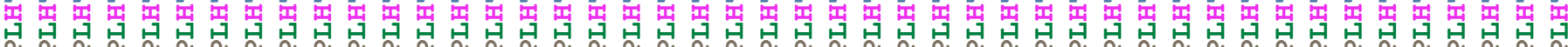

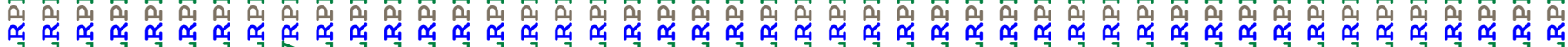

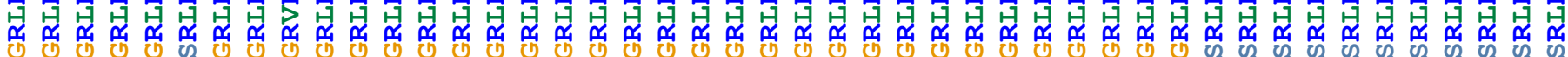

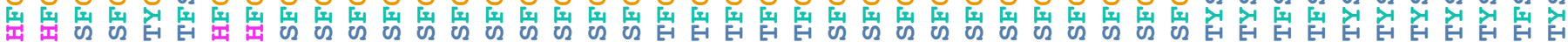

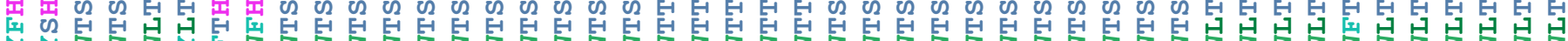

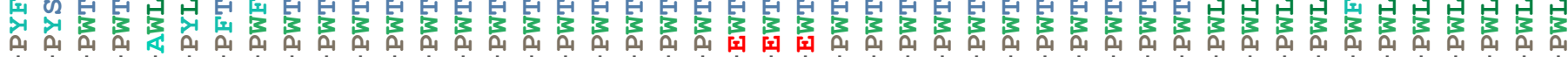

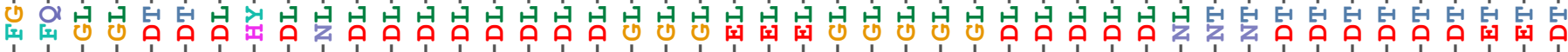

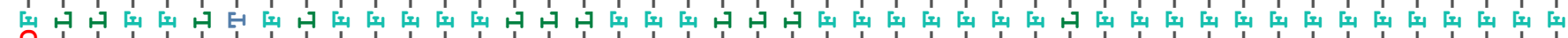
1

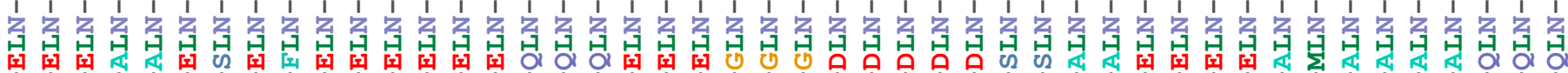

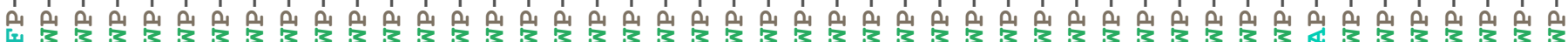

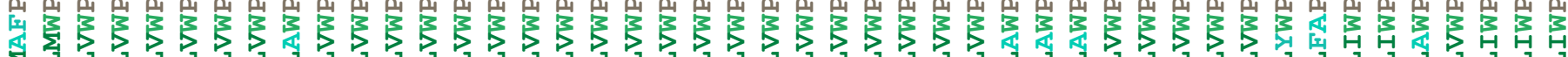

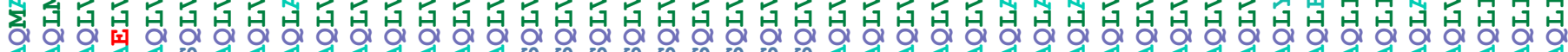

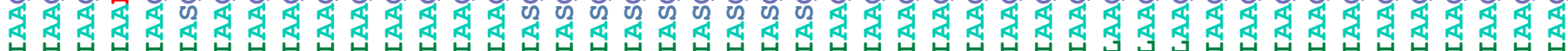

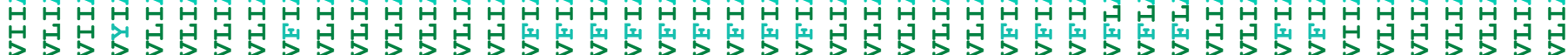

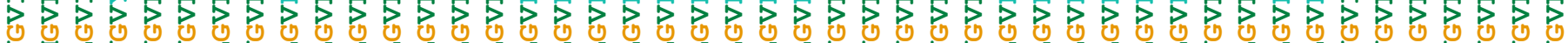

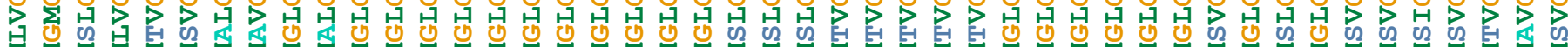

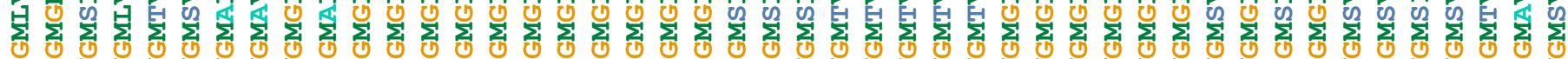

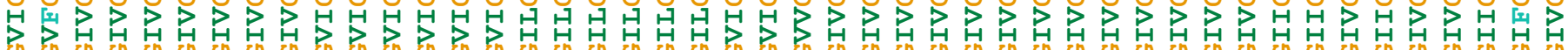

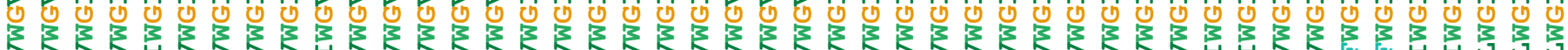

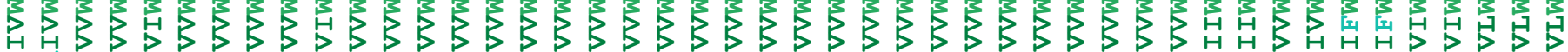

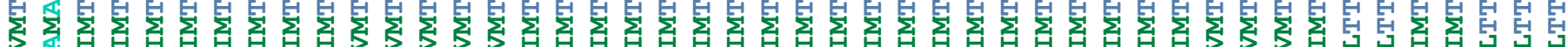

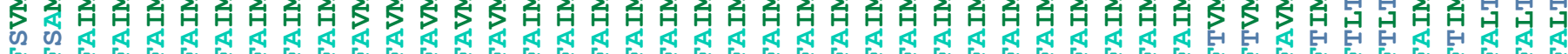

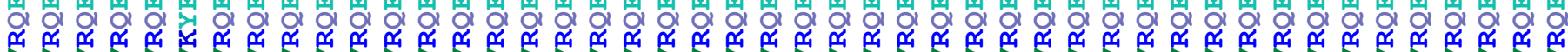
3535353535353535353535353535353535353535

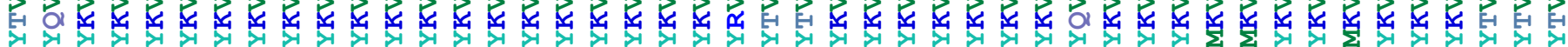

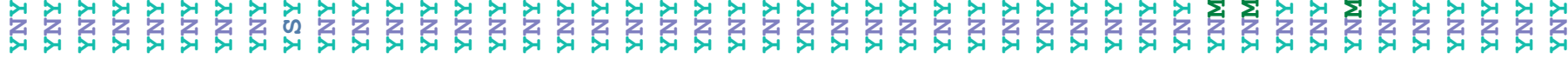

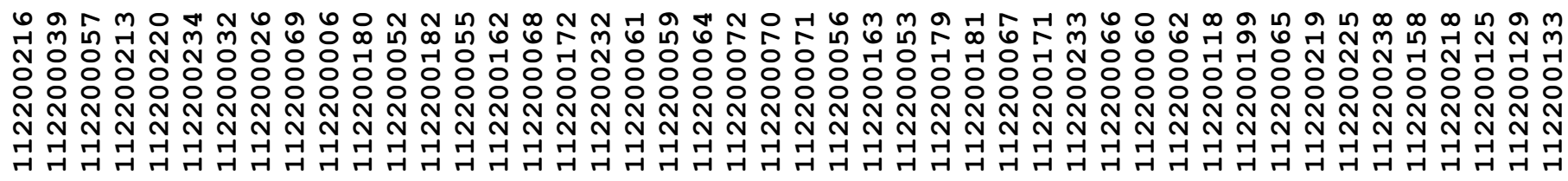




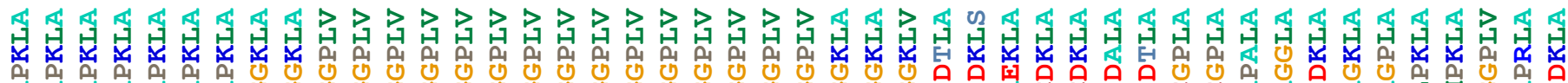
死

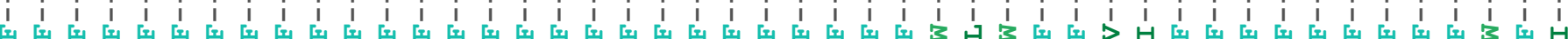

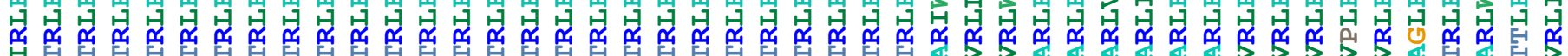
O인

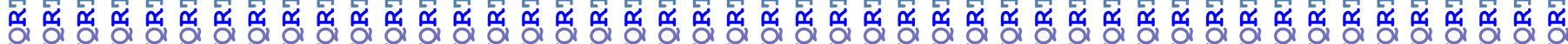

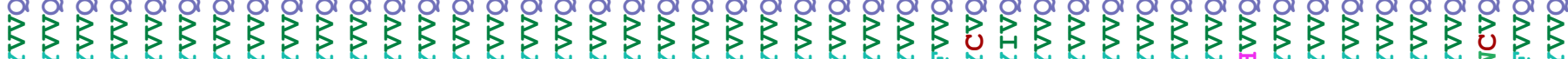
서

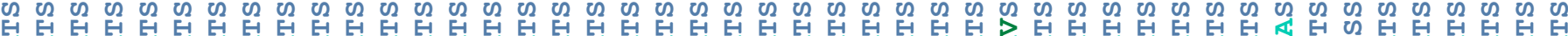

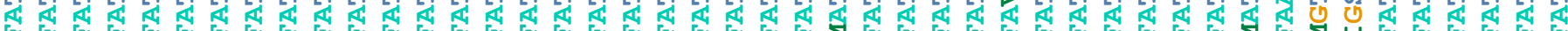

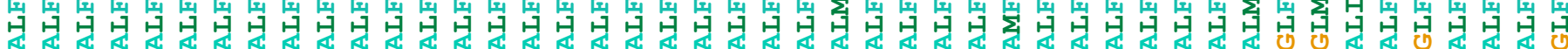
๗

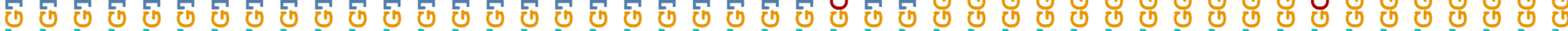

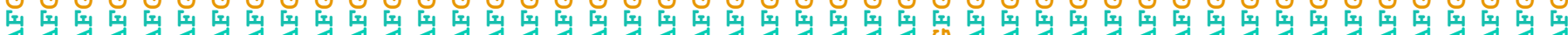

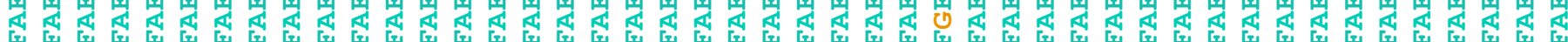

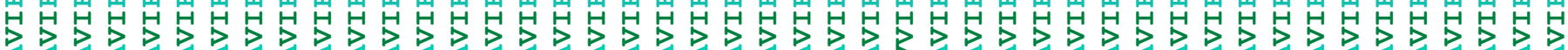

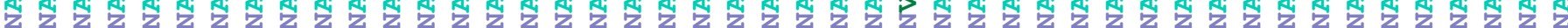

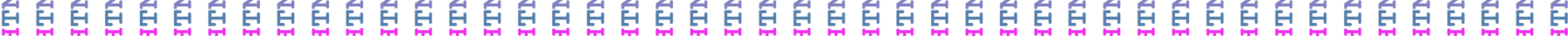

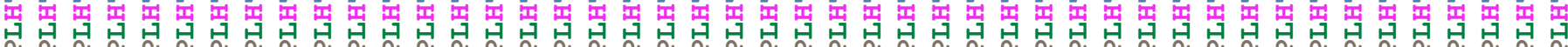

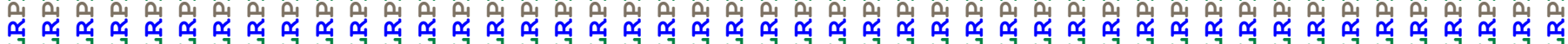

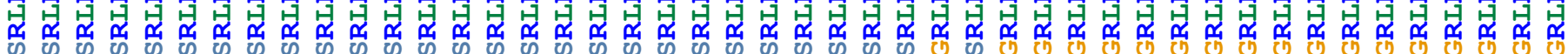

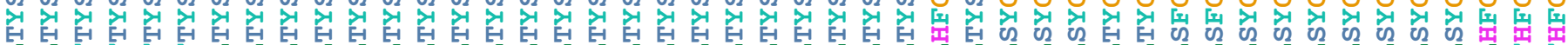

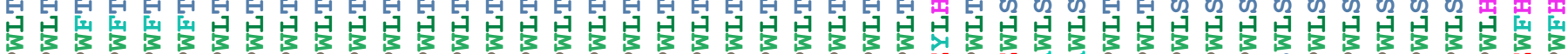

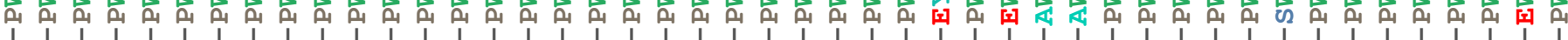

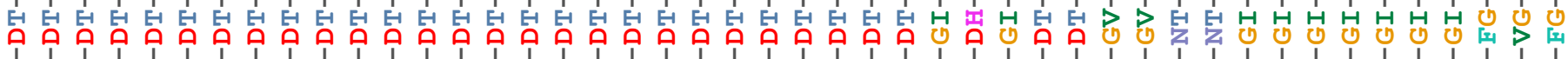

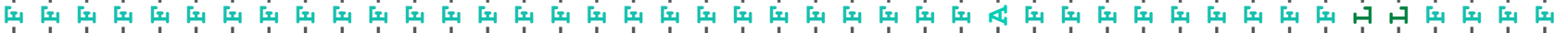

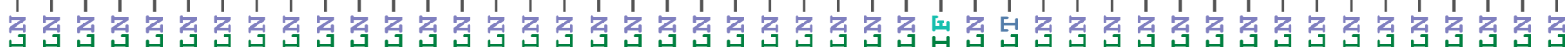

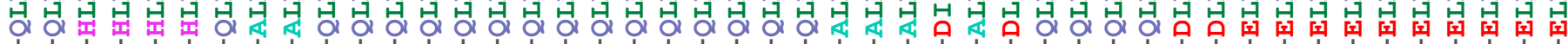

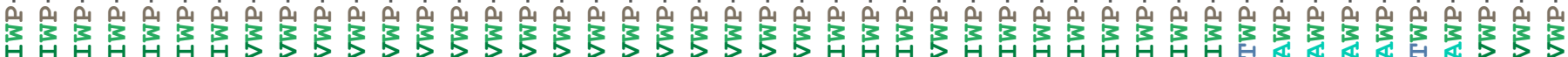

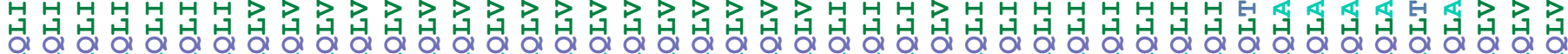

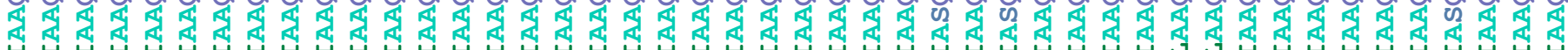

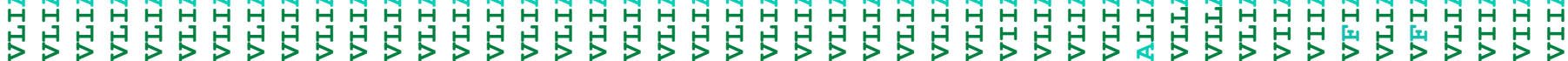

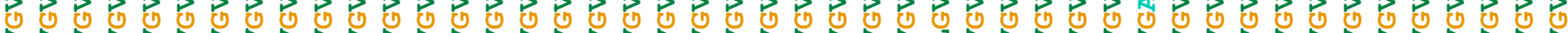

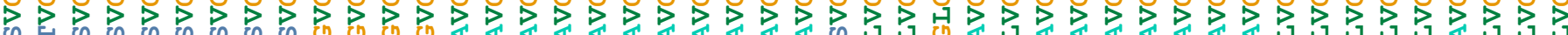

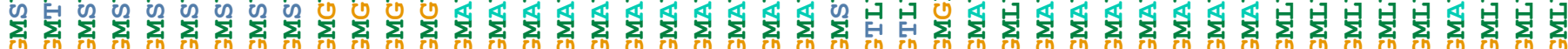

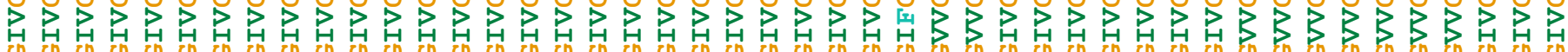

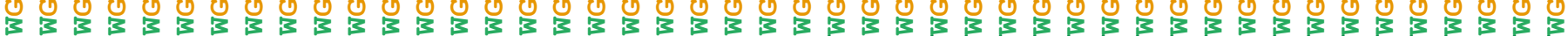

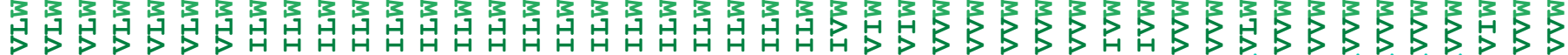

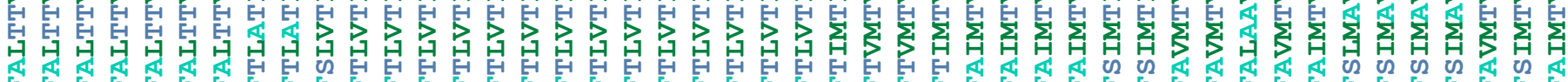
O 0 , O

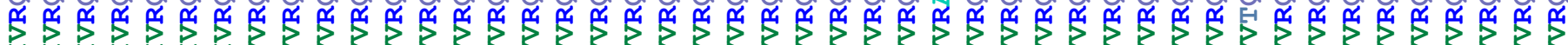

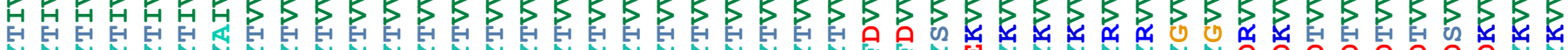

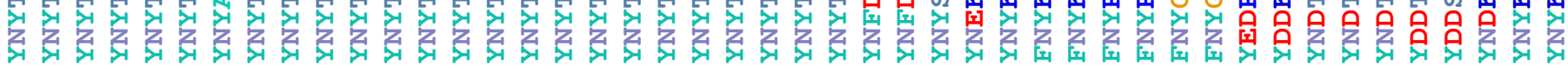

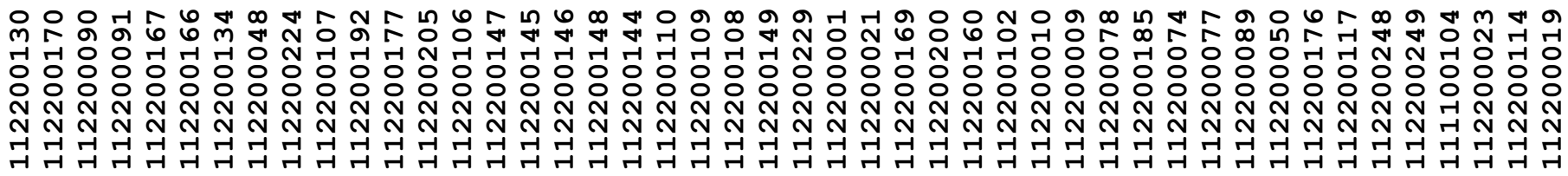




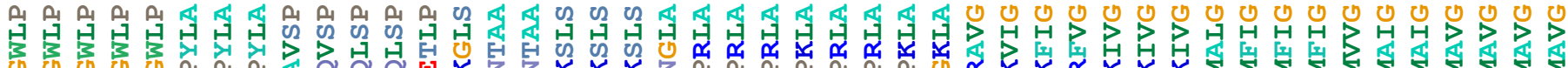

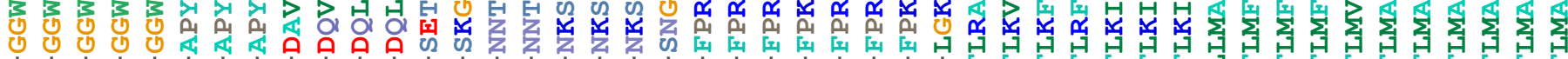

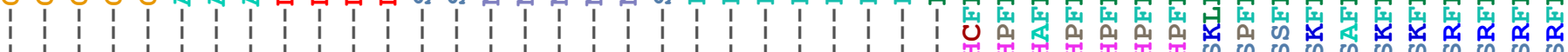

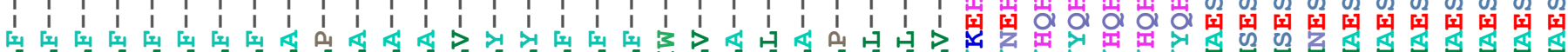

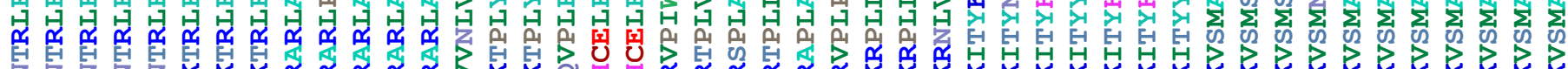

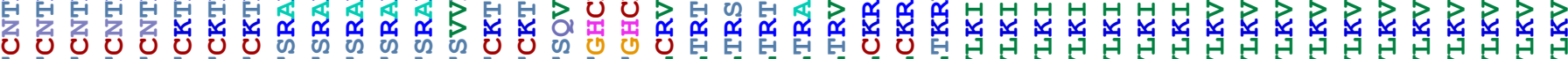

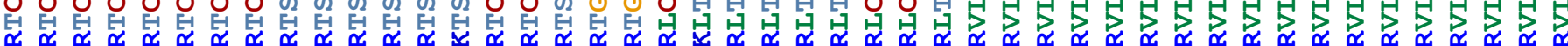

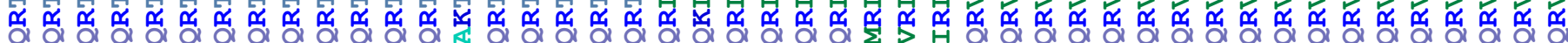

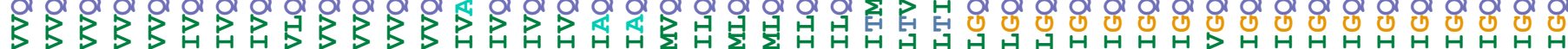
ટ્ર,

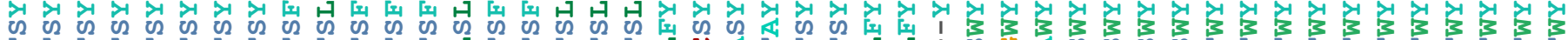

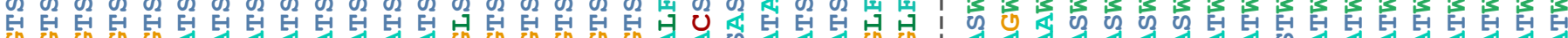

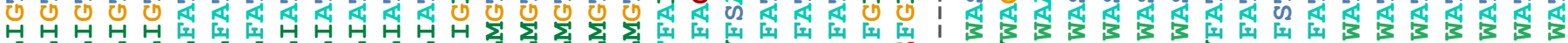

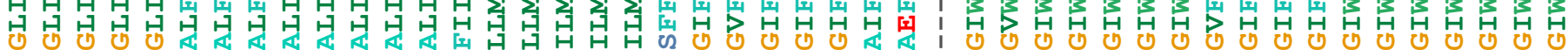

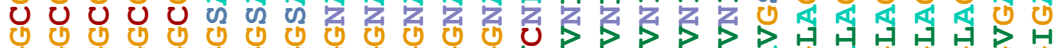
才ण

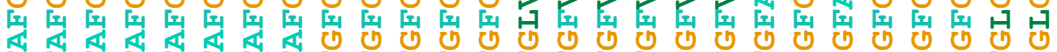

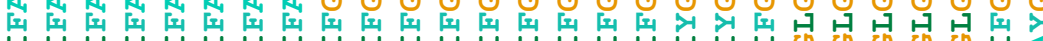

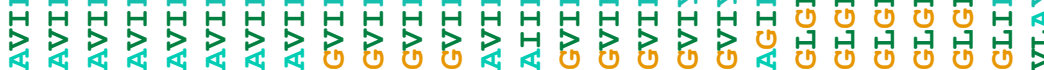

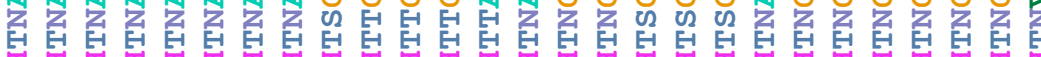

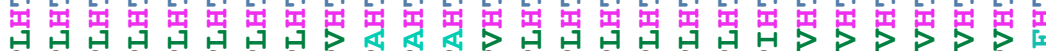

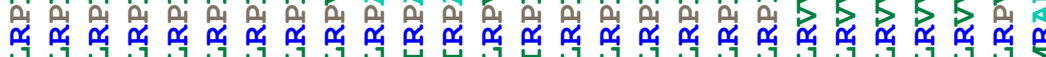

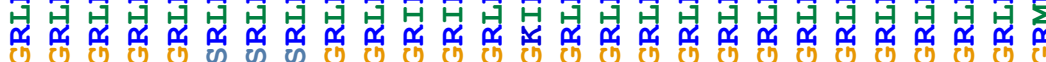

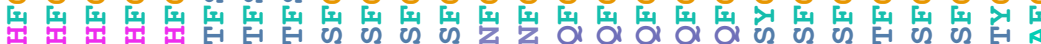

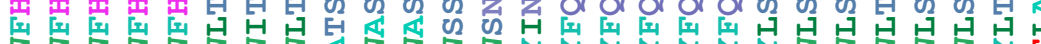

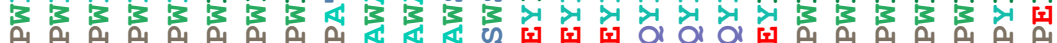
C

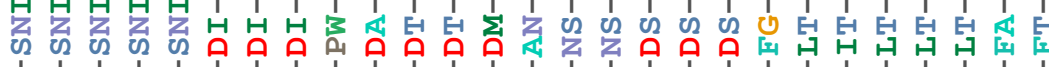

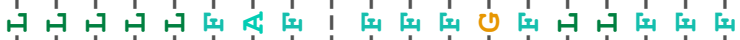

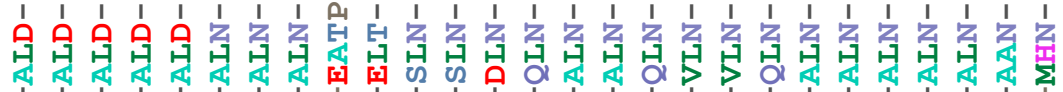

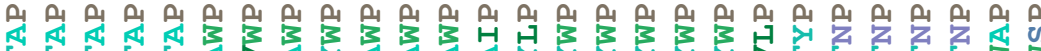

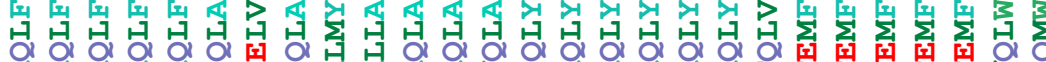

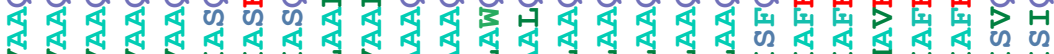

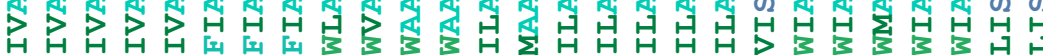

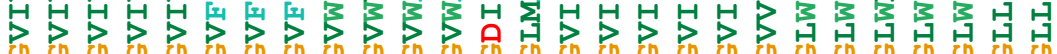

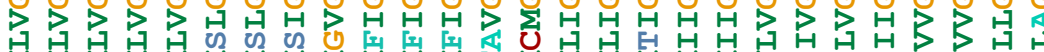

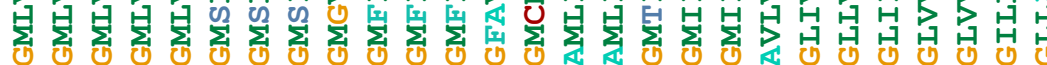

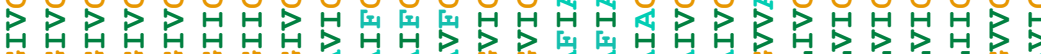

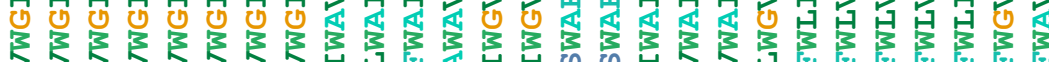

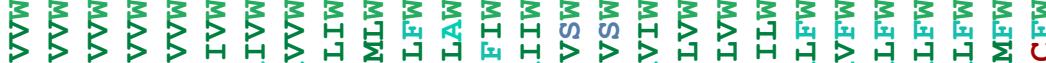

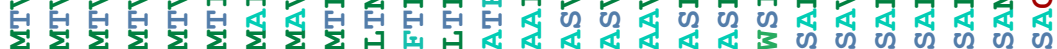

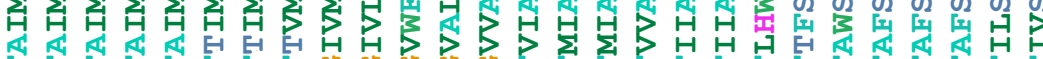

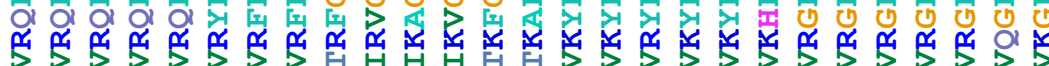

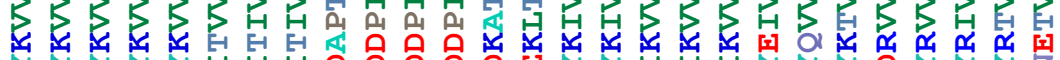

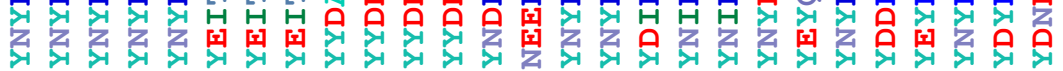
记

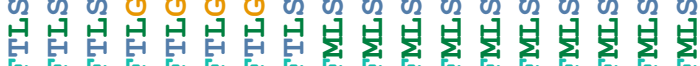

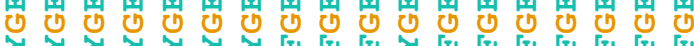

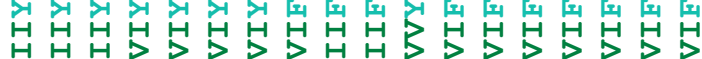

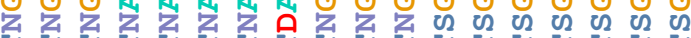

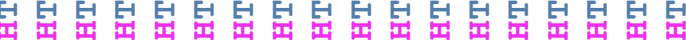

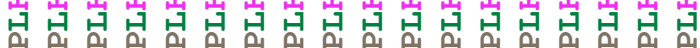

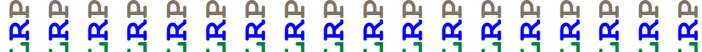

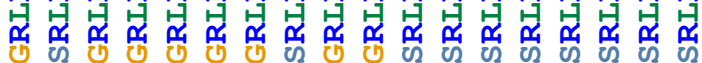

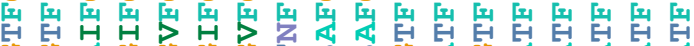

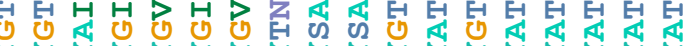

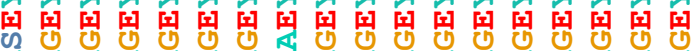

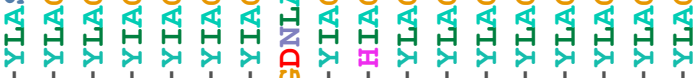

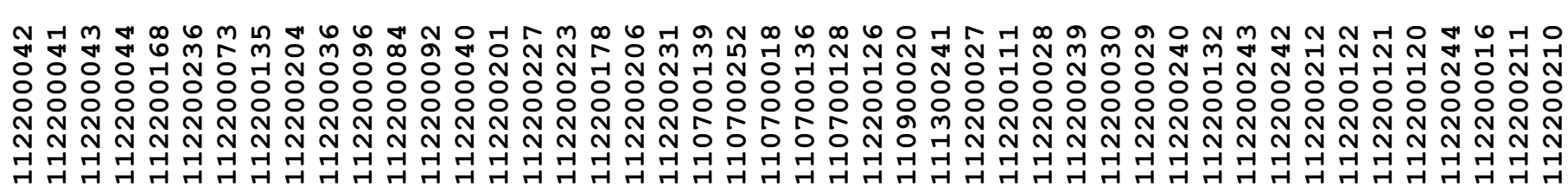




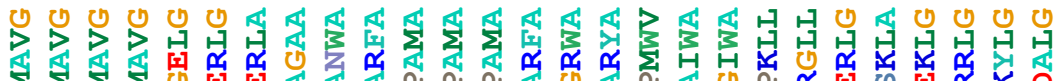

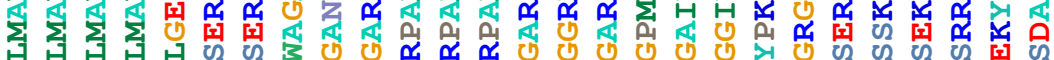

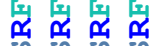

\section{थ थ}

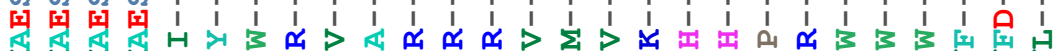

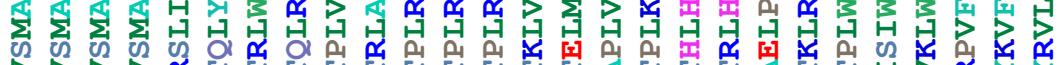

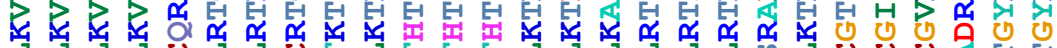

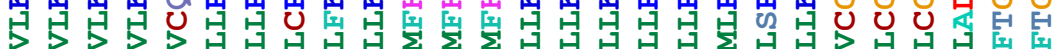

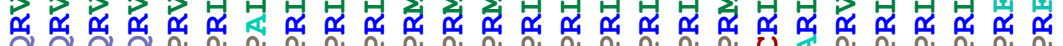

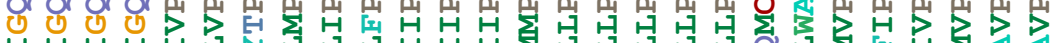

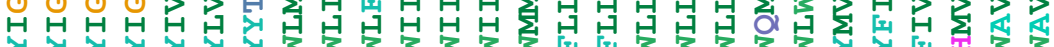

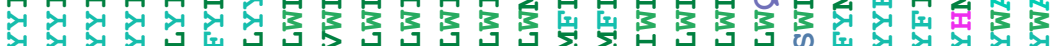

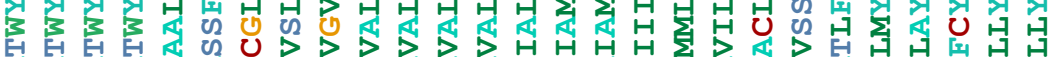

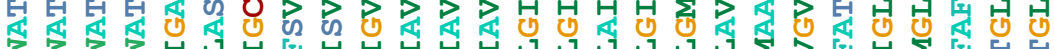

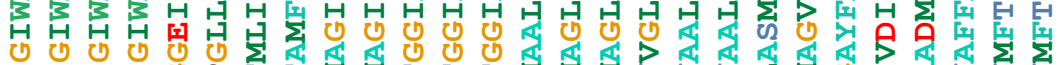
ળળ

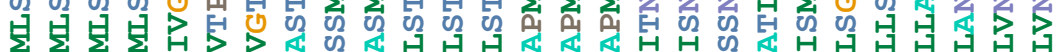

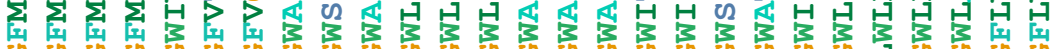

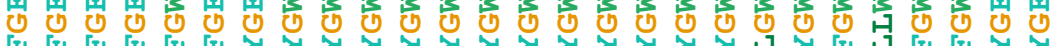

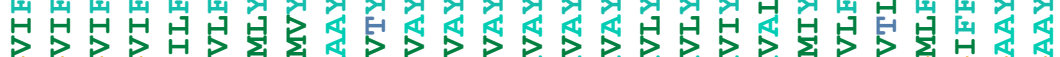

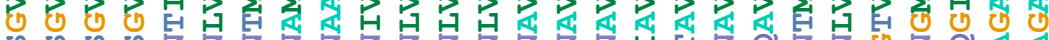

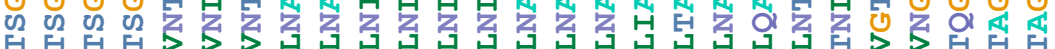

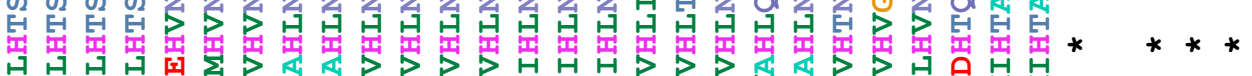

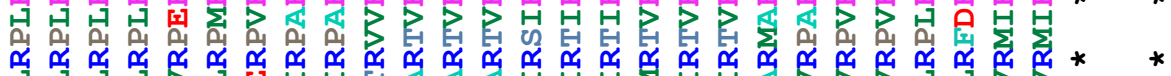

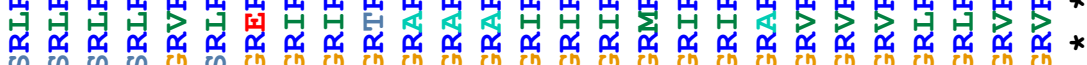

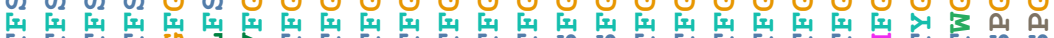

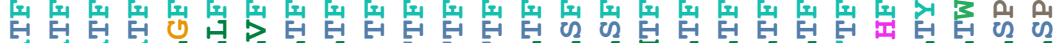

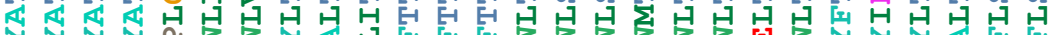

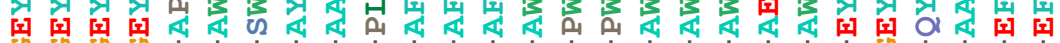

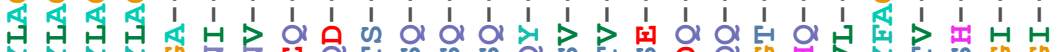

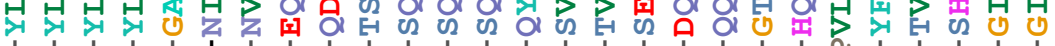

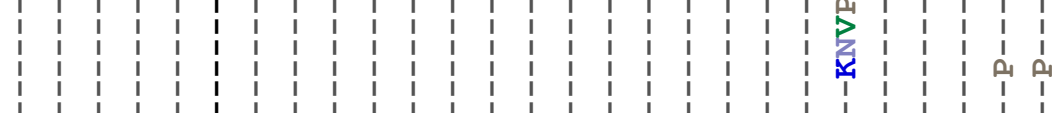

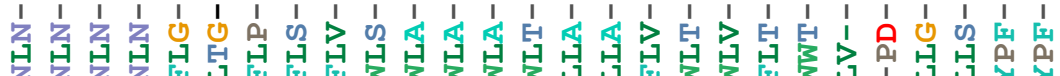

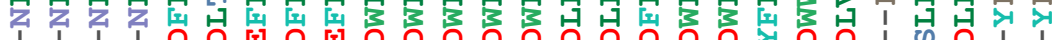

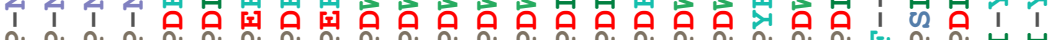

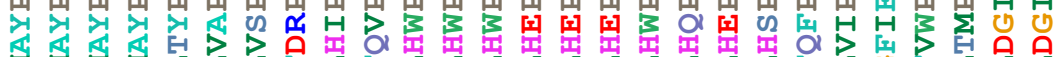

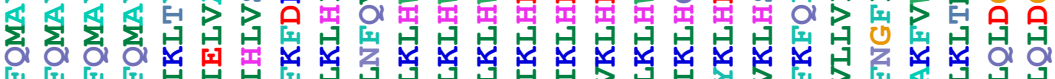

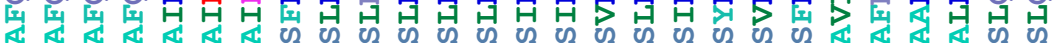

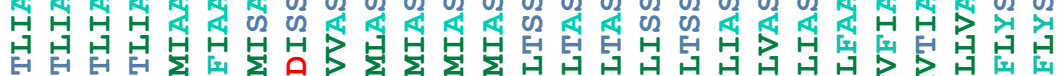

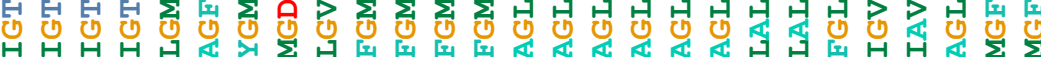

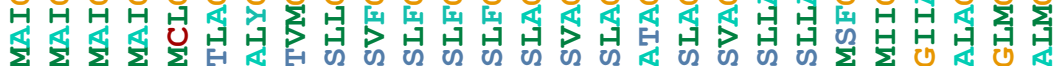

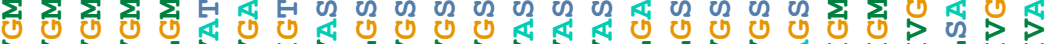

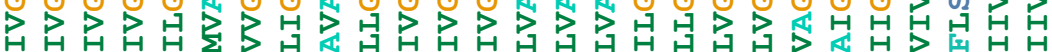

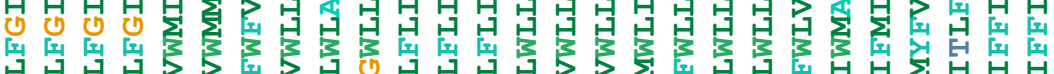

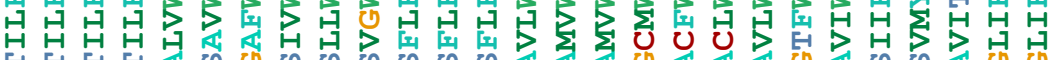

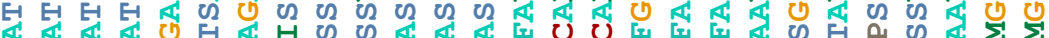

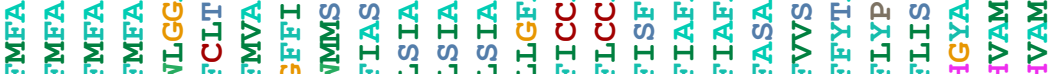

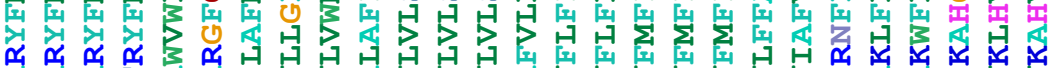

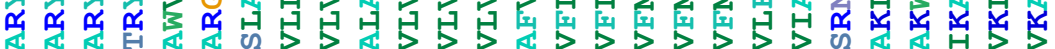

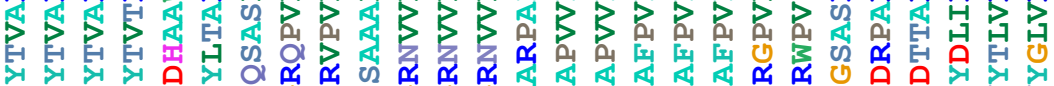

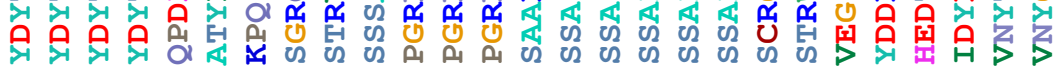

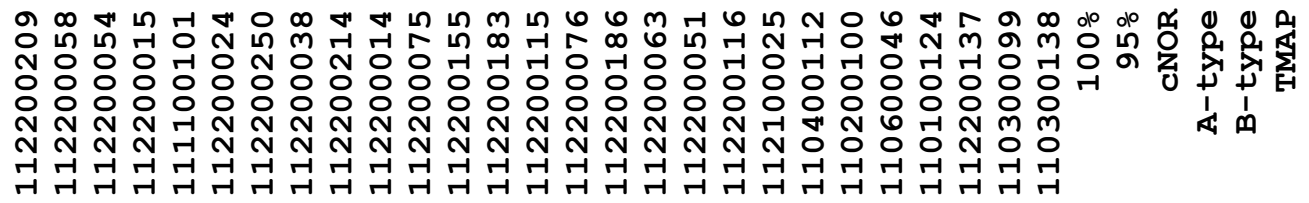

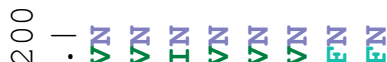

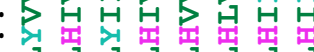

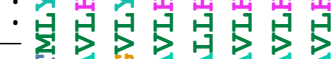

: 留出出芯近

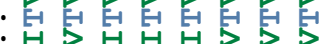

ด.

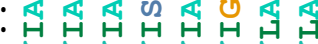

年

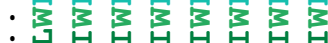

-

$\infty-2<?<2<?$

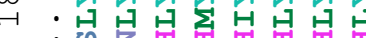

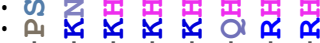

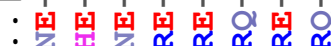

- I I I I I I

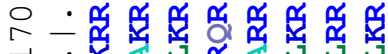

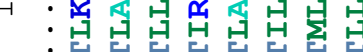

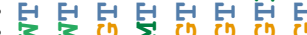

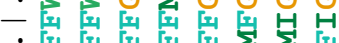

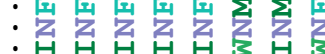

: H草是皆运

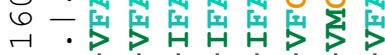

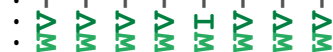

- $H S P H$

: 最是最最昆 作

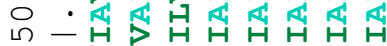

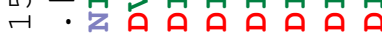

- ar ar ar ar ar ar ar or

- 1 l 1 l

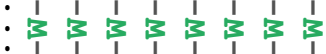

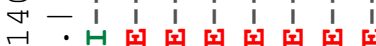

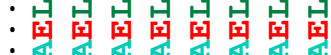

-

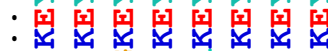

$\therefore$ ह 2 है

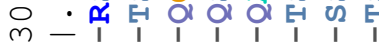

m-

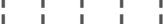

- D F

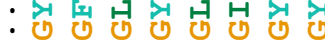

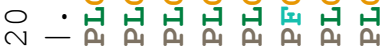

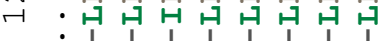

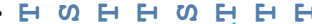

. $H H H H \leftrightarrow H H$

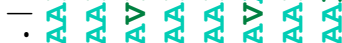

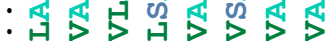

○ $-H A H H H A$

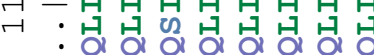

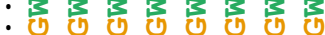

- 1325

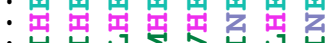

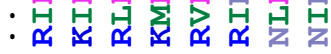

L 0 m $\infty N \in$

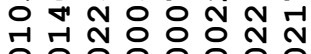
응응ㅇㅇㅇㅇㅇㅇㅇㅇㅇㅇㅇㅇㅇ N N

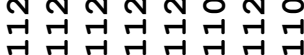




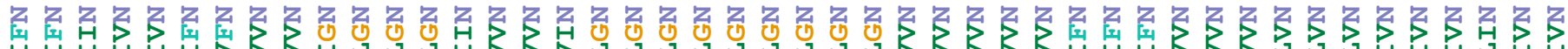

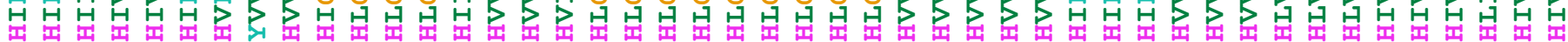

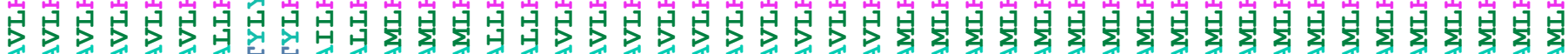

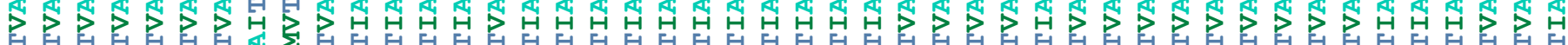

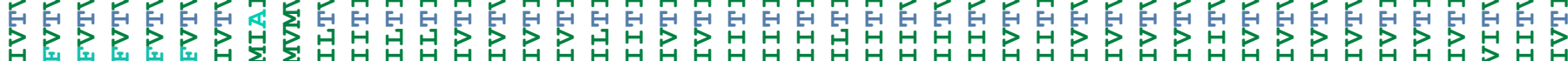

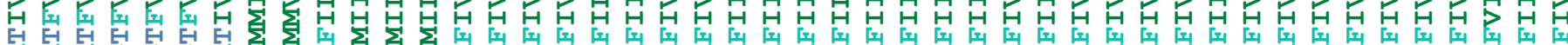

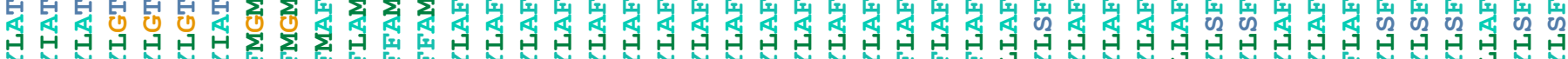

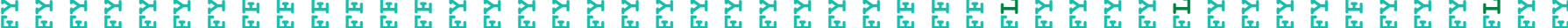

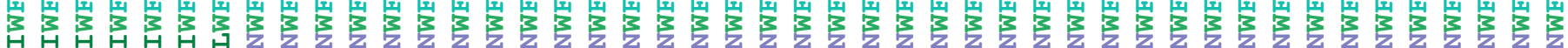

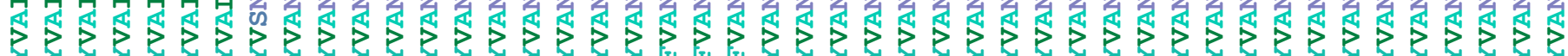

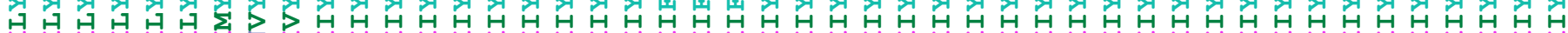

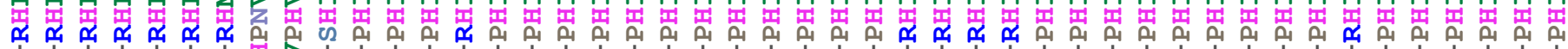

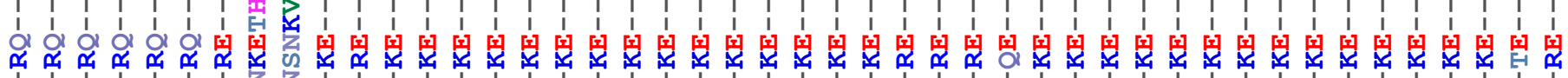

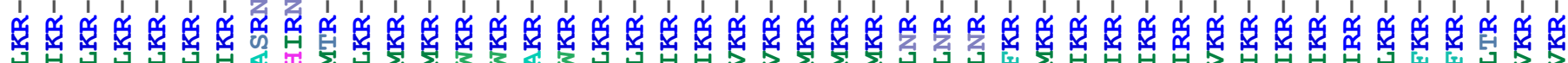

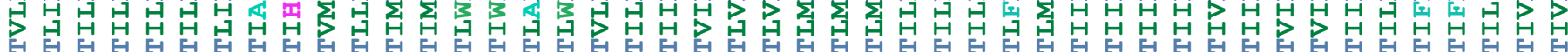

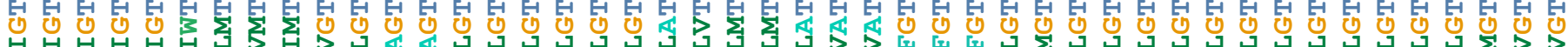
年

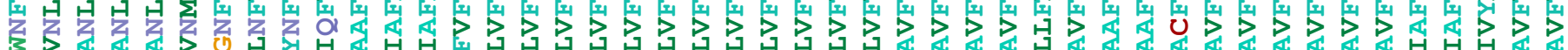

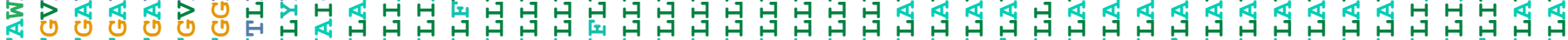

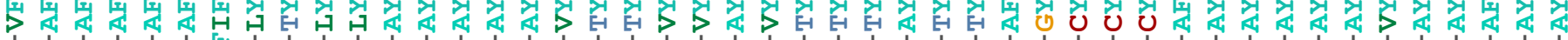

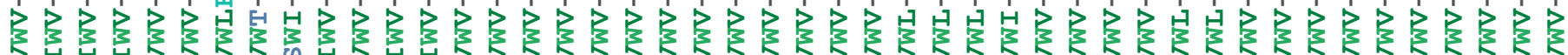

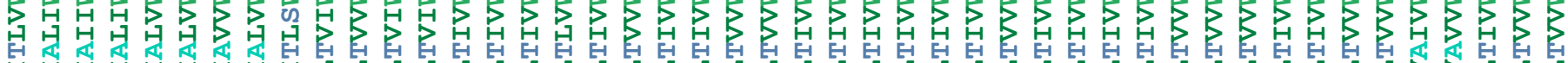

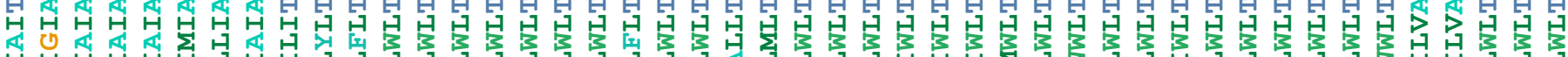

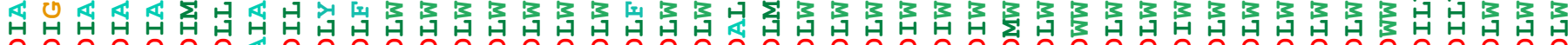

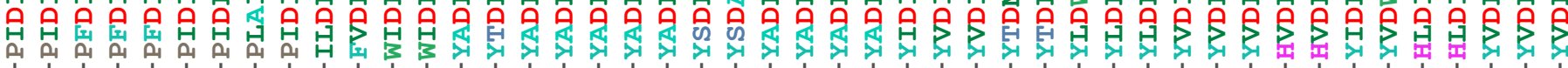

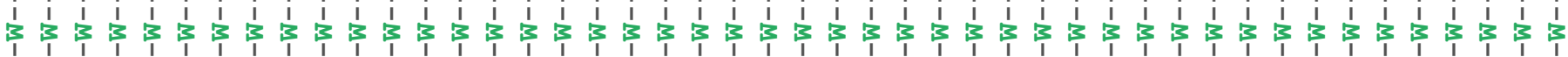

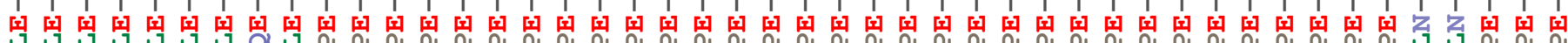

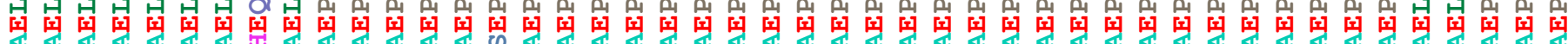

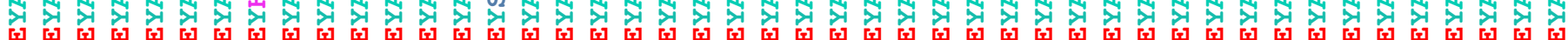

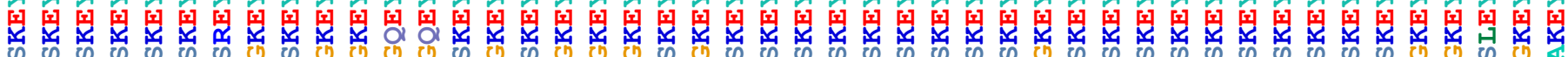
E en

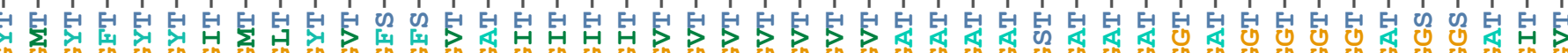

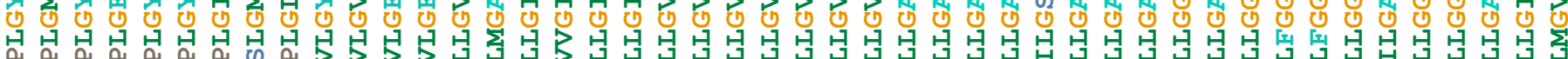

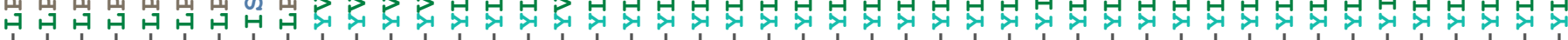

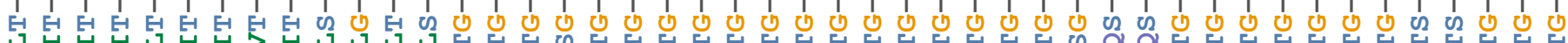

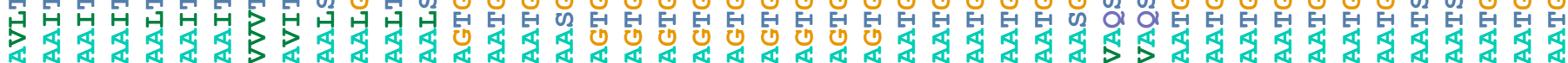

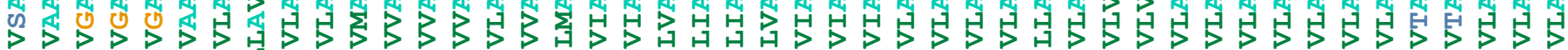
H

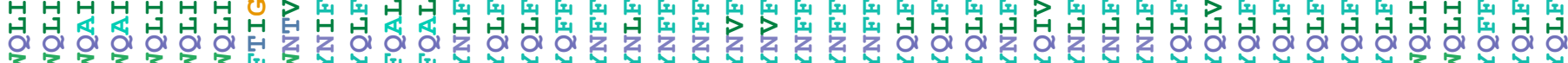

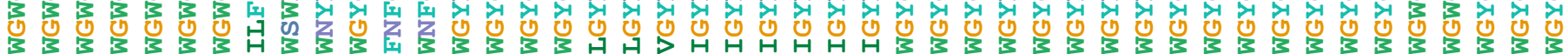

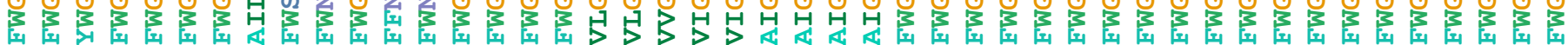

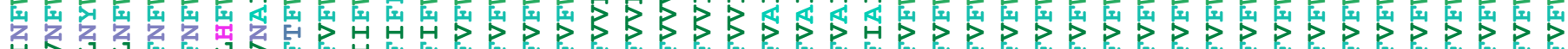

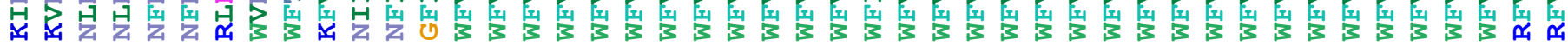

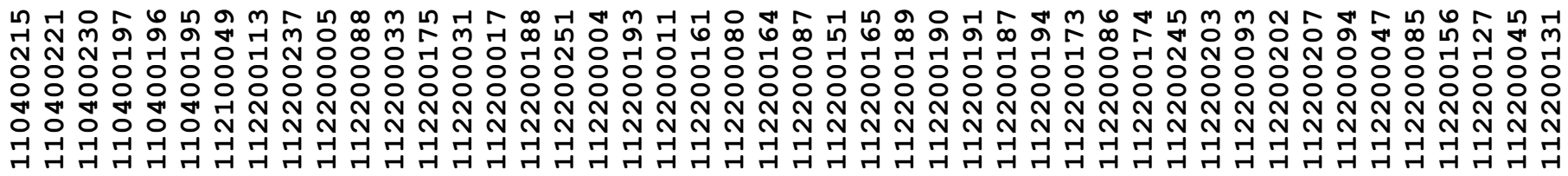




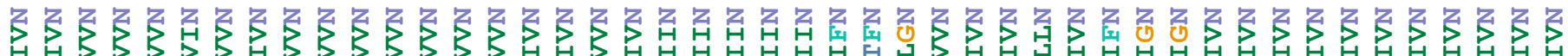

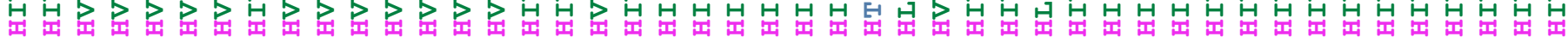

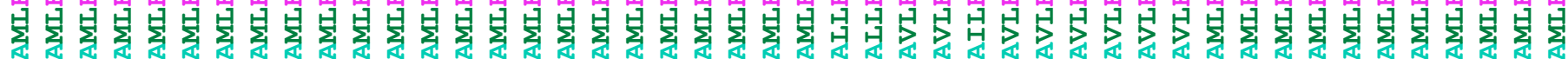

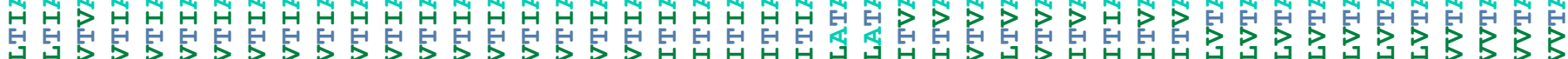

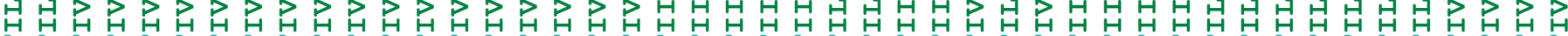

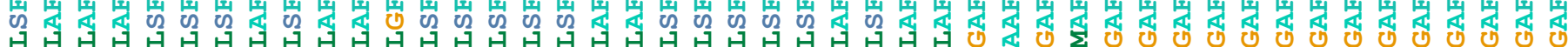

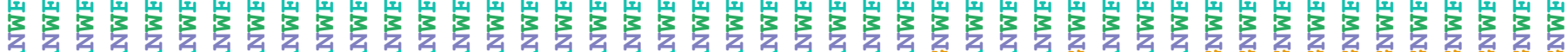

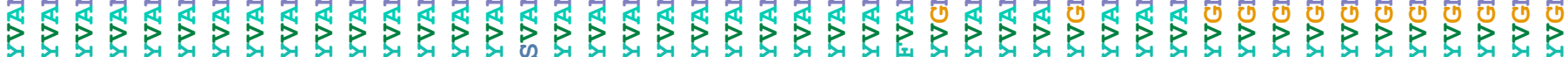

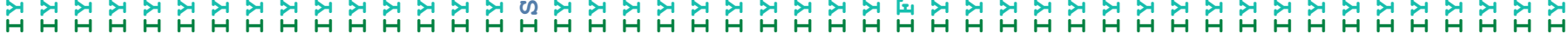

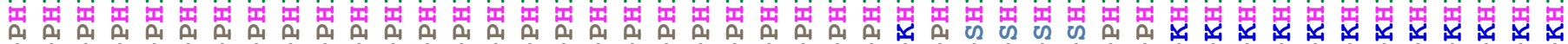

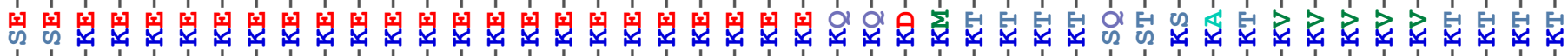

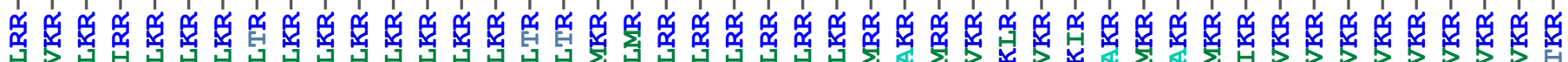

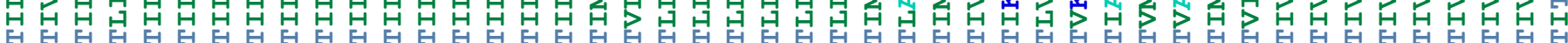

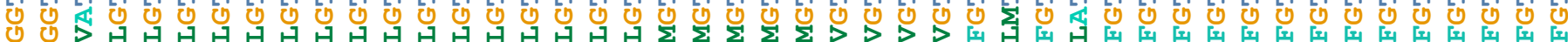

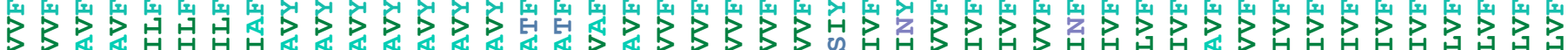

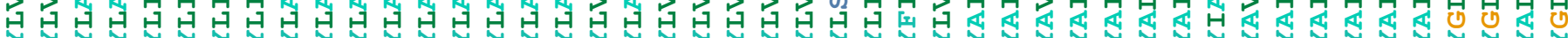

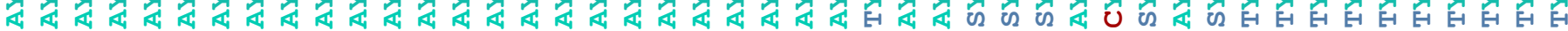

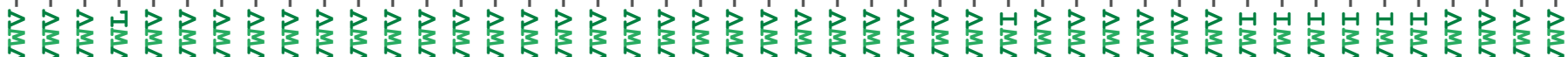

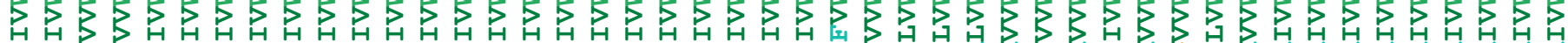

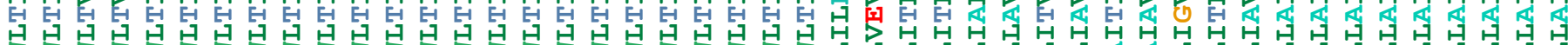

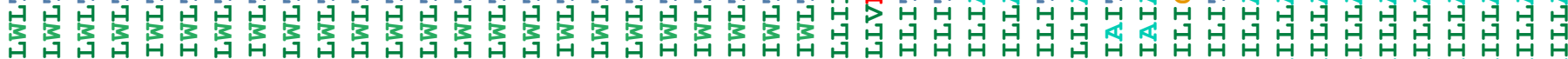

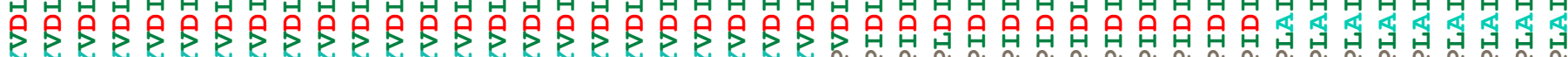

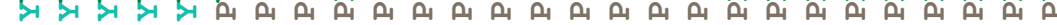

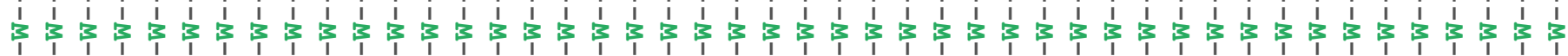

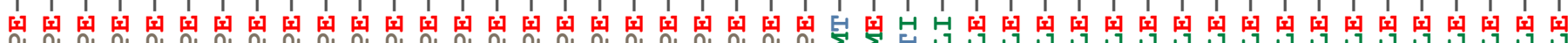

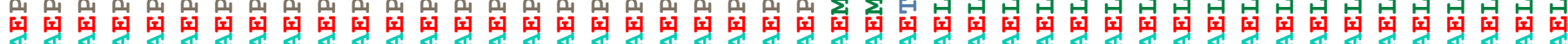

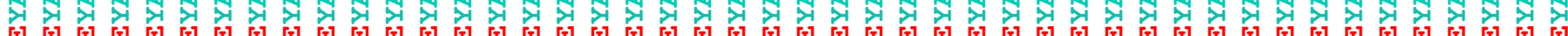

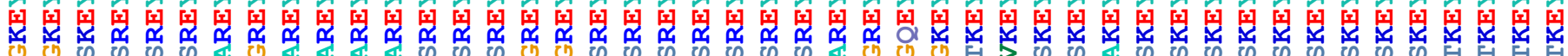

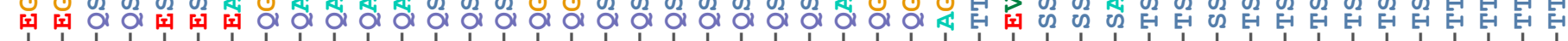

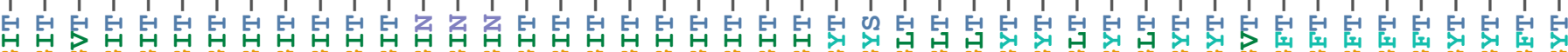

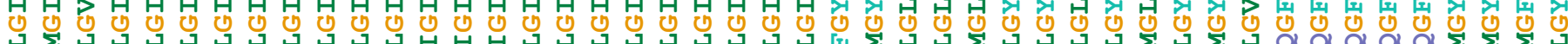

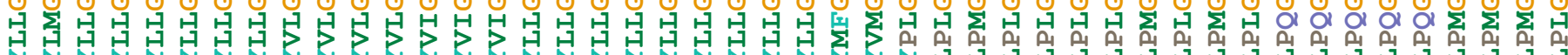

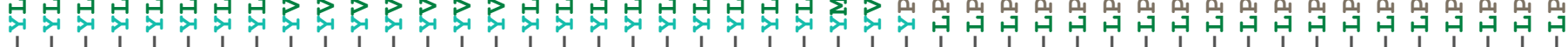

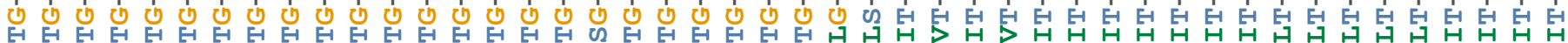

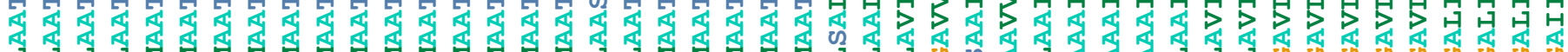

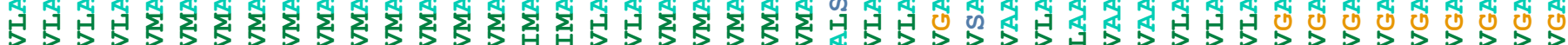

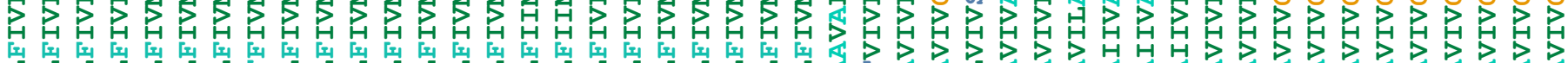

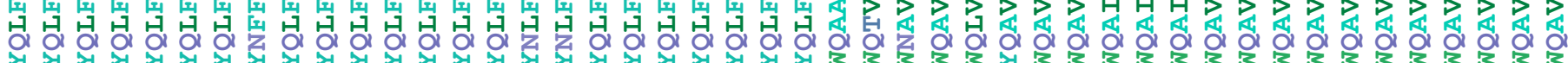

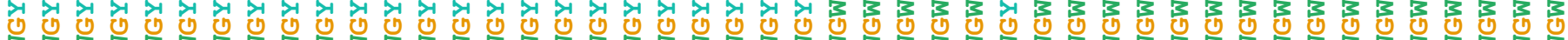

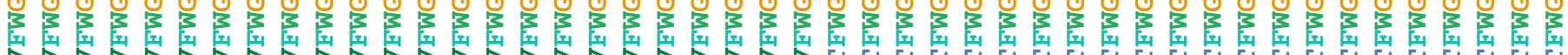

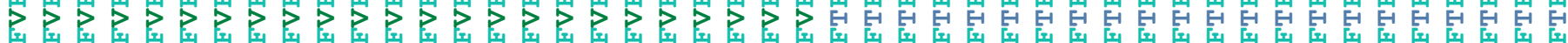

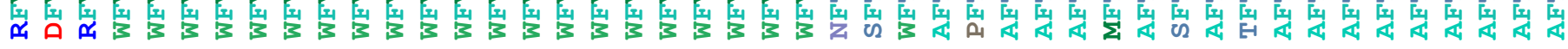

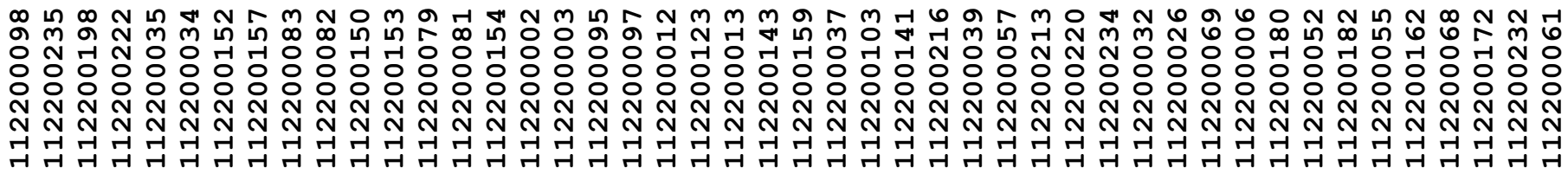




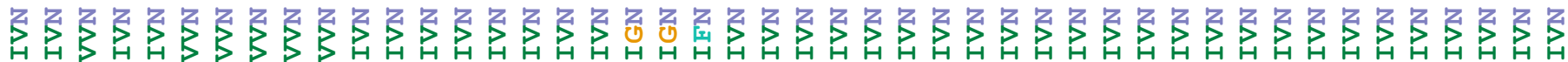

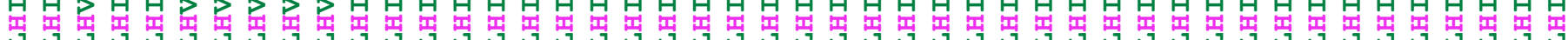

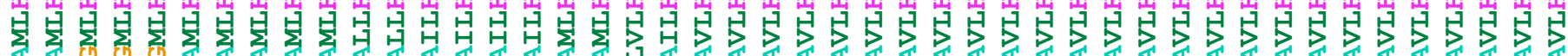

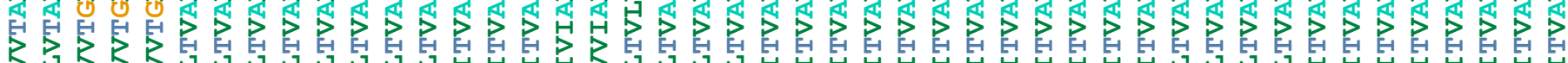

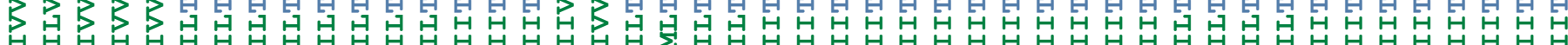

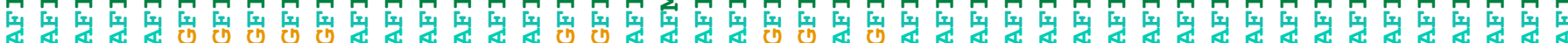

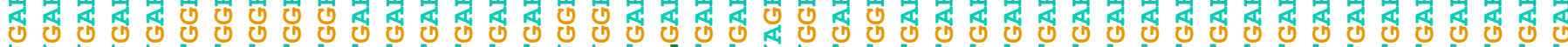

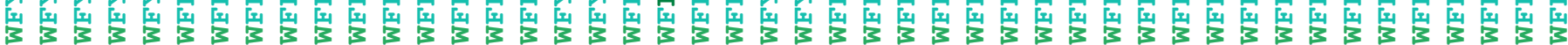

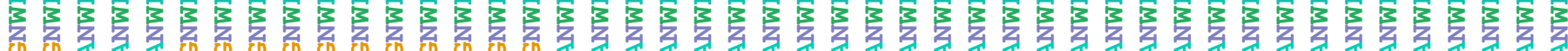

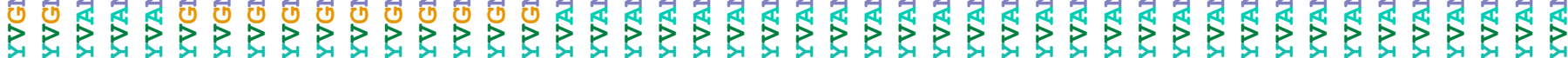

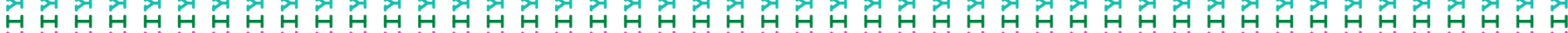

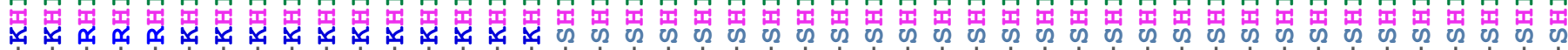

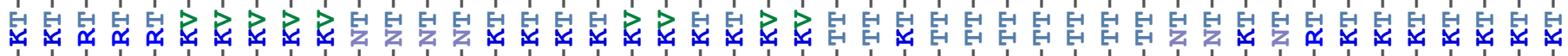

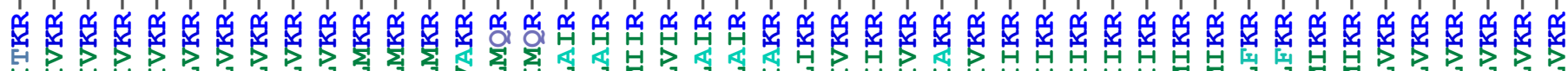

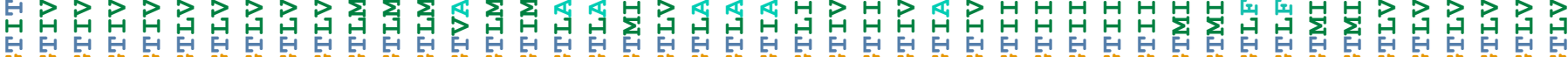

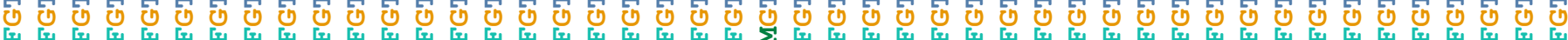

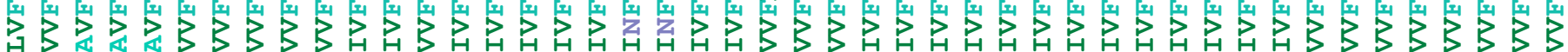

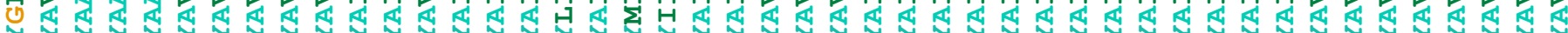

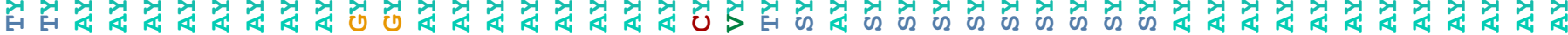

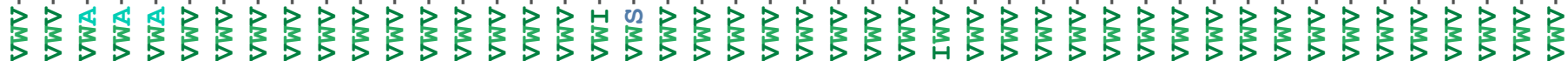

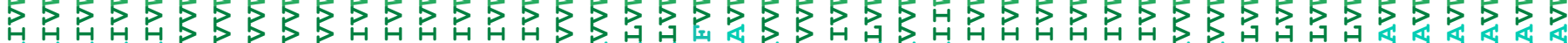

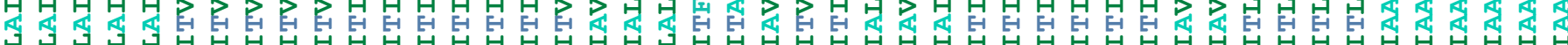

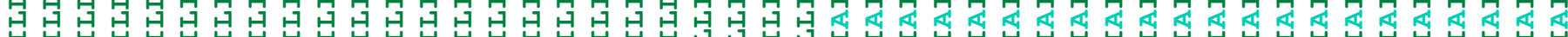

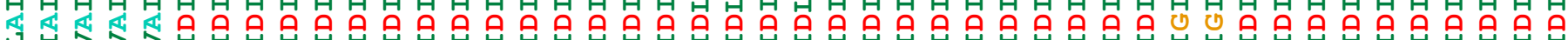

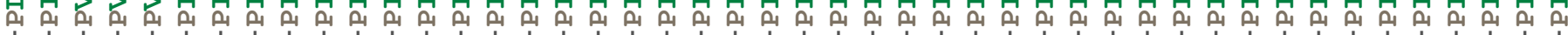

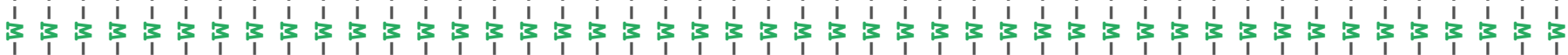

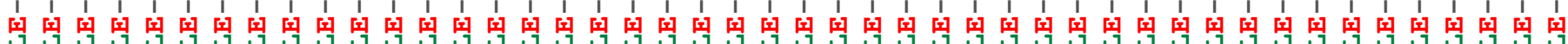

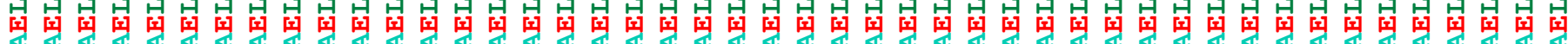

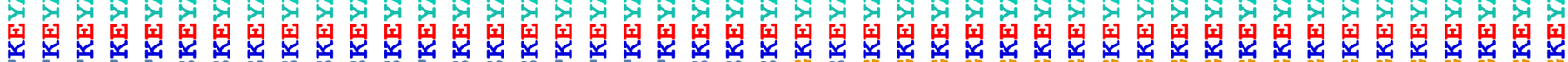

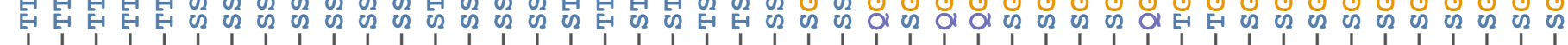
1

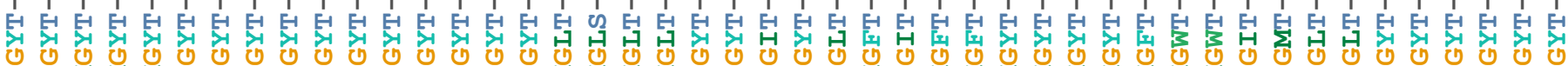

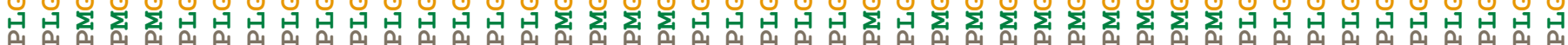

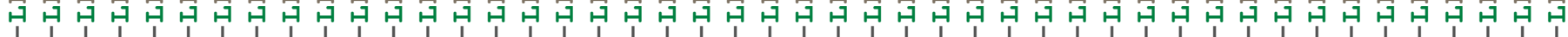
F5

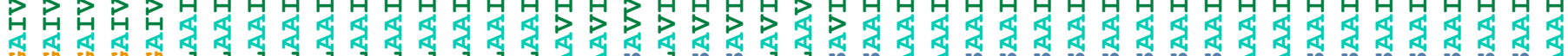

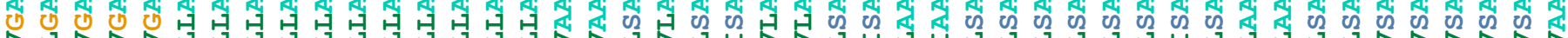

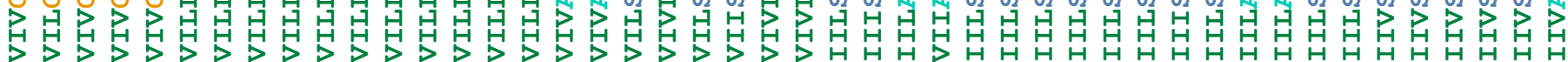
至

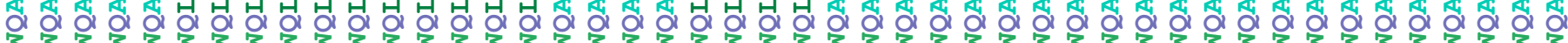

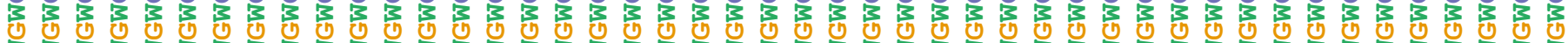

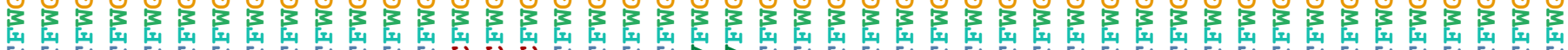

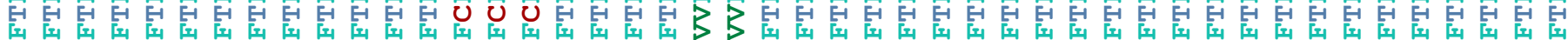

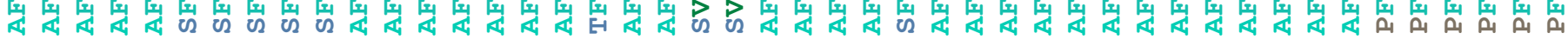

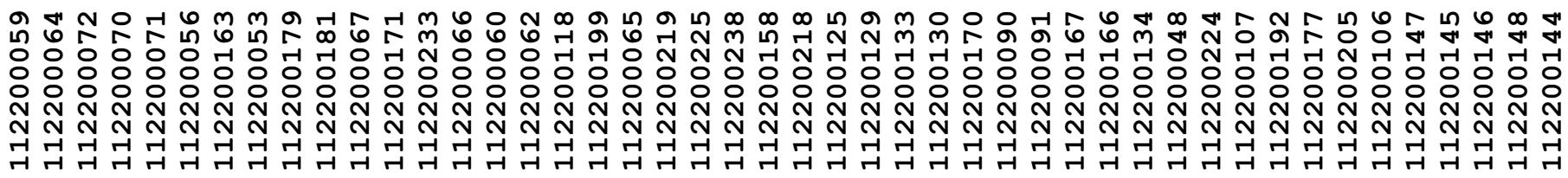




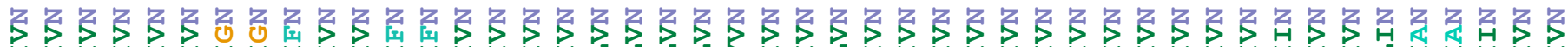

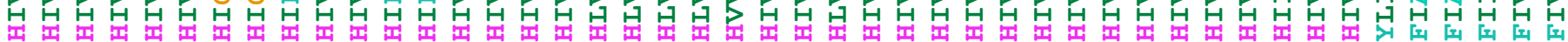

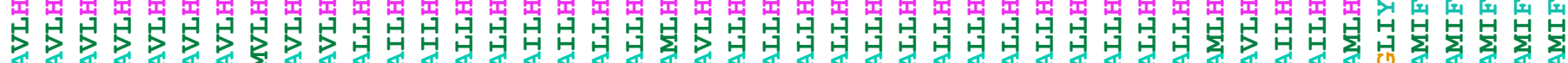

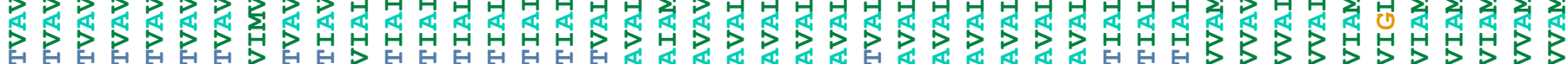

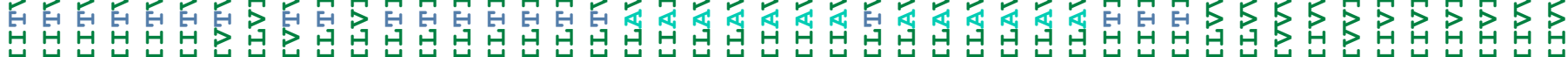

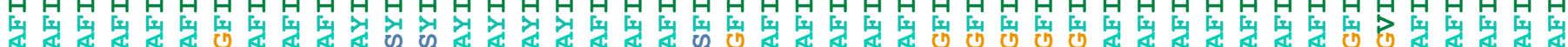

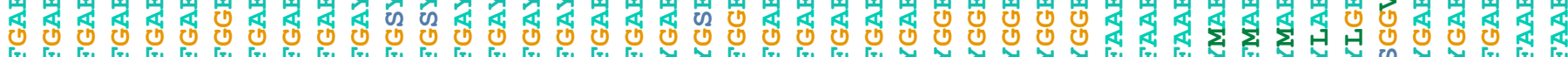

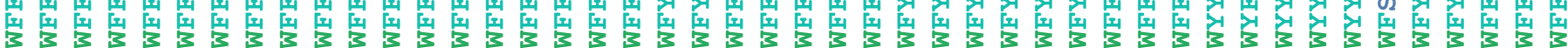

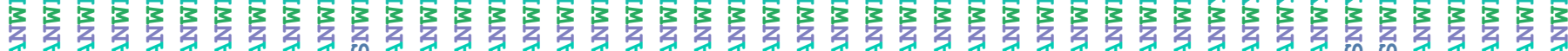

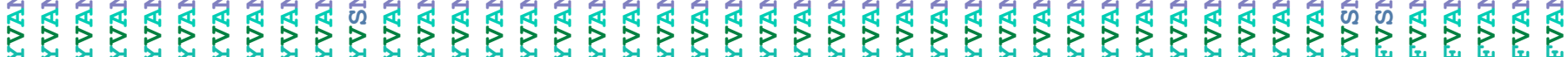

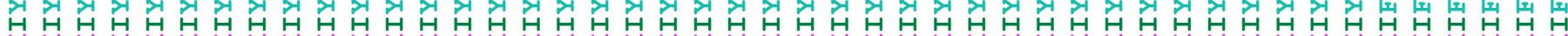

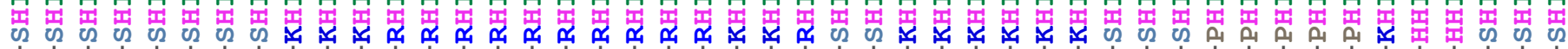

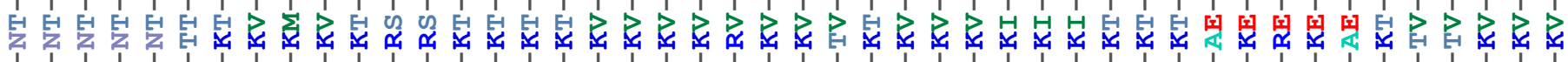

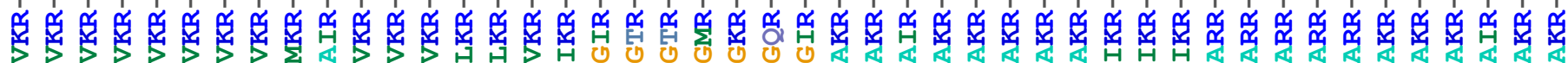

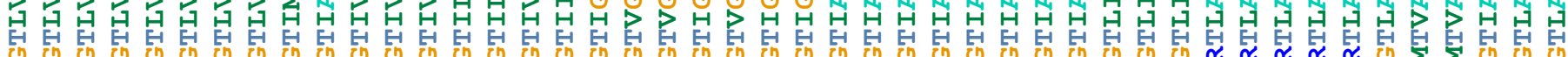

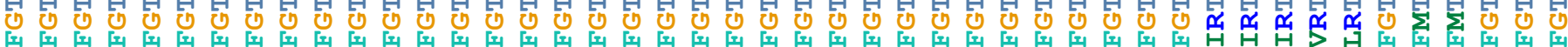

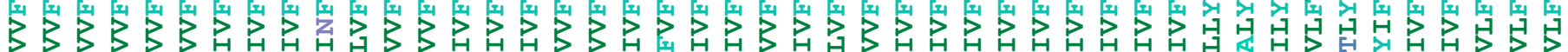

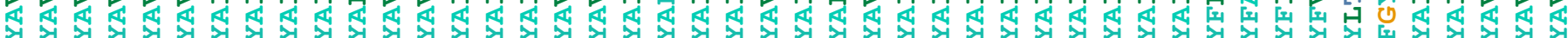

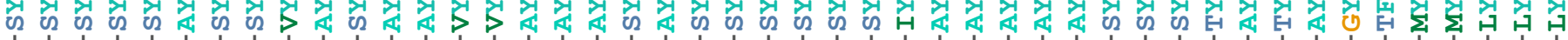

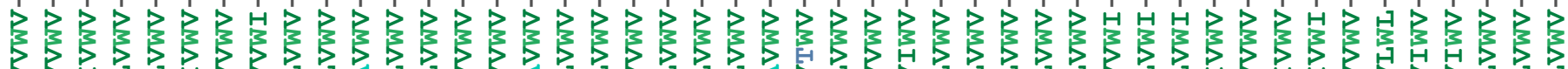

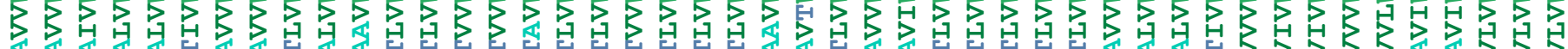

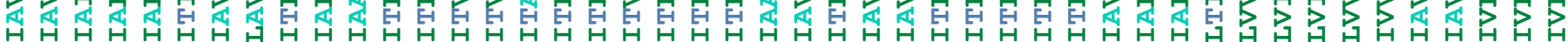

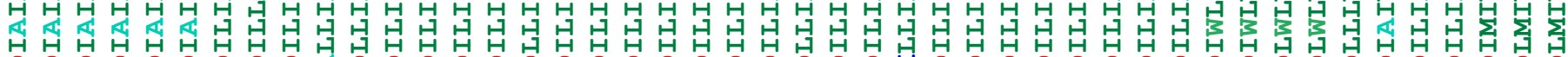

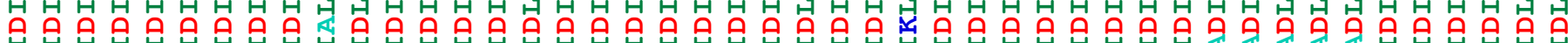
$\alpha_{1} \alpha_{1} \alpha_{1} \alpha_{1} \alpha_{1} \alpha_{1} \alpha_{1} \alpha_{1} \alpha_{1} \alpha_{1} \alpha_{1} \alpha_{1} \alpha_{1} \alpha_{1} \alpha_{1} \alpha_{1} \alpha_{1} \alpha_{1} \alpha_{1} \alpha_{1} \alpha_{1} \alpha_{1} \alpha_{1} \alpha_{1} \alpha_{1} \alpha_{1}$

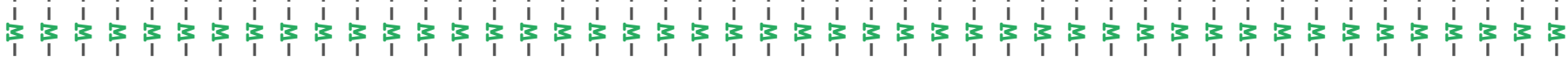

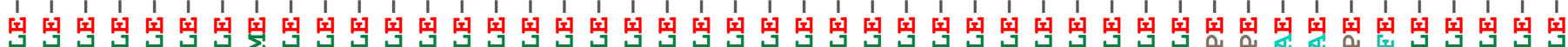

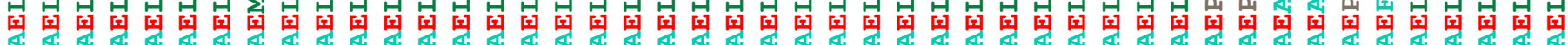

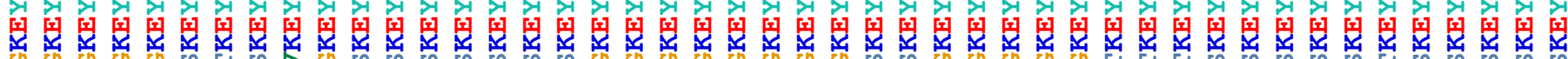

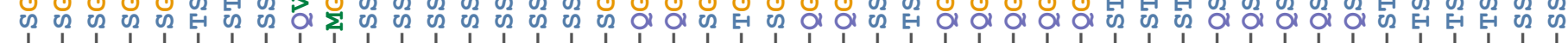

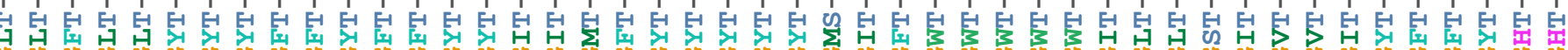

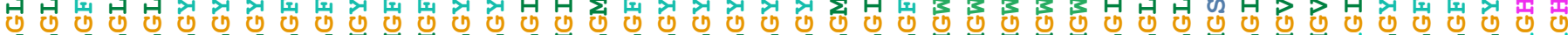

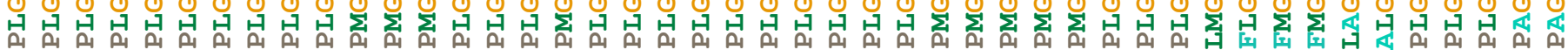

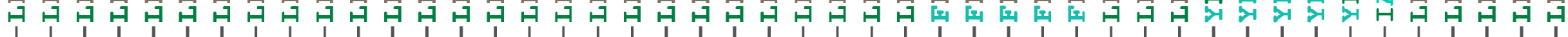

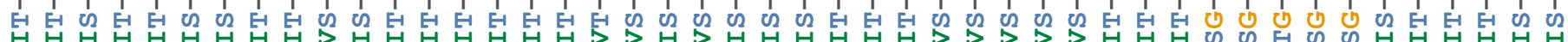

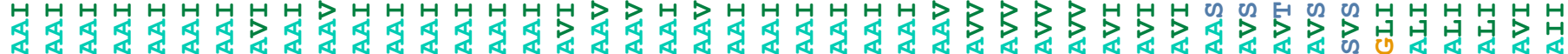
A

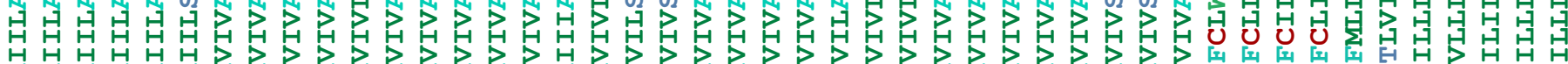

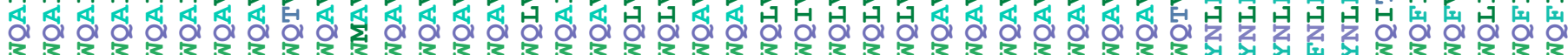

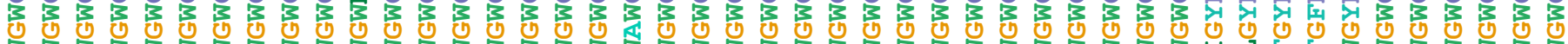

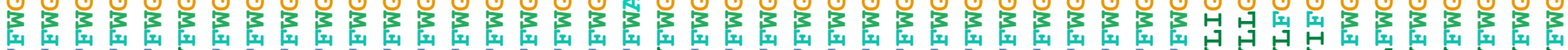

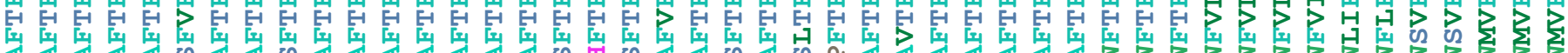

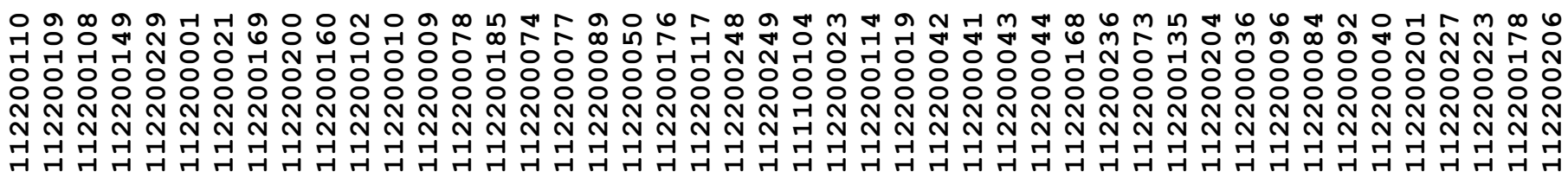




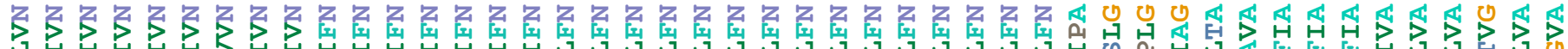

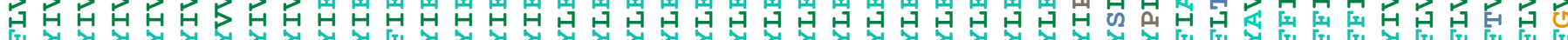

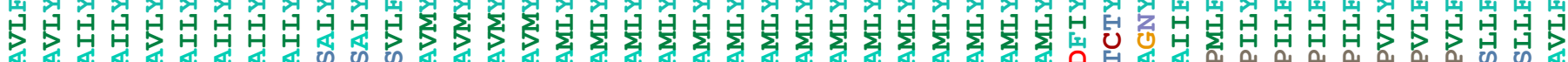

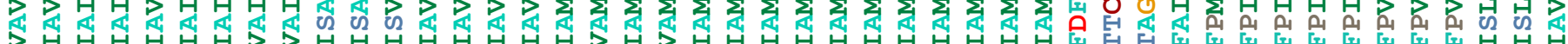

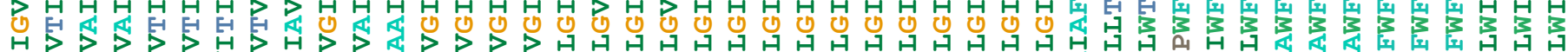

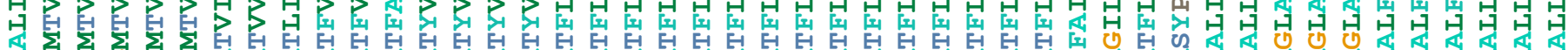

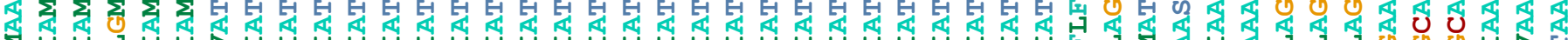

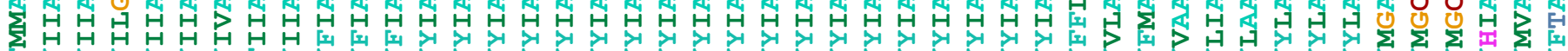

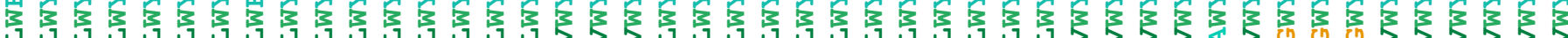

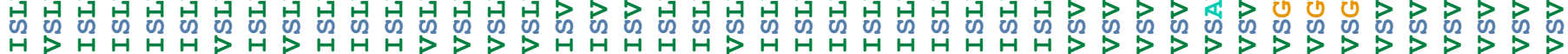

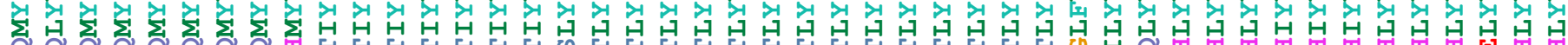

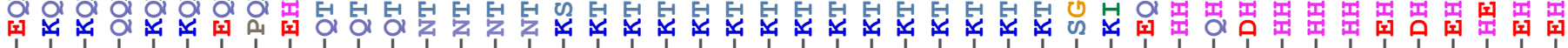

国舆

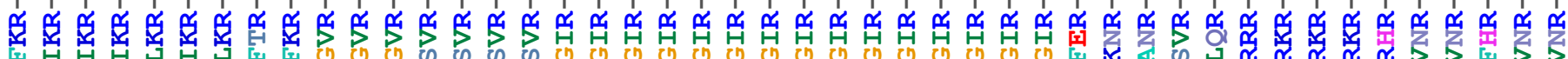

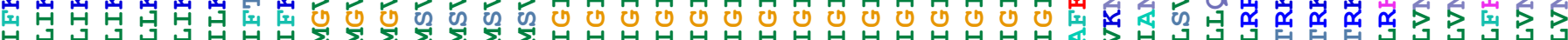

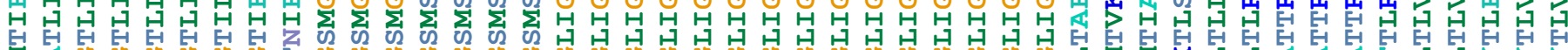

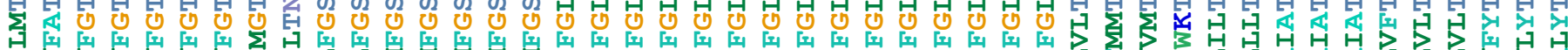

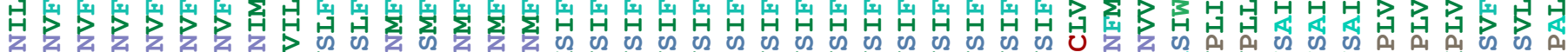

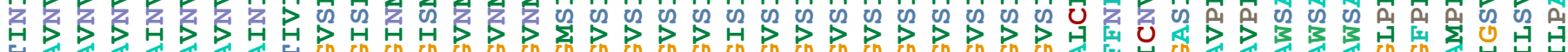

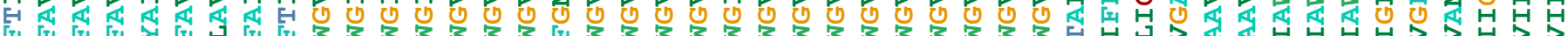

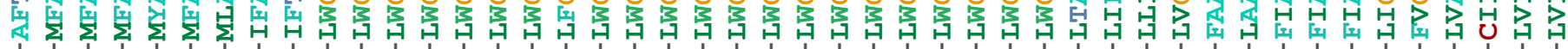

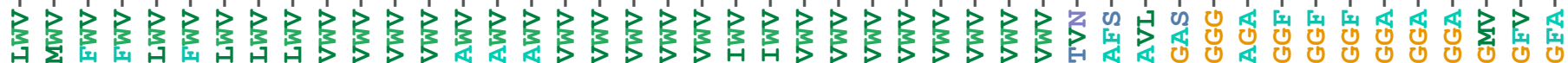

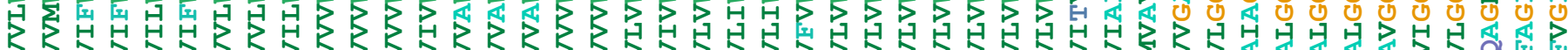

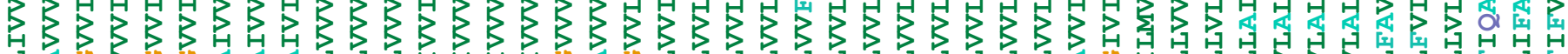

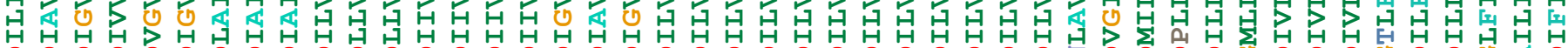

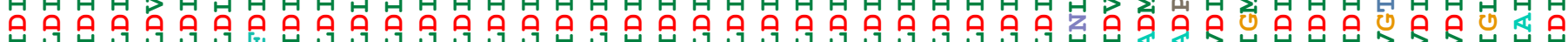

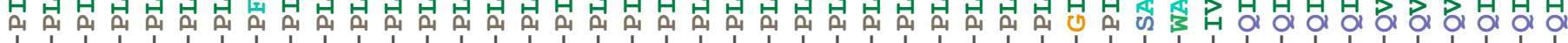

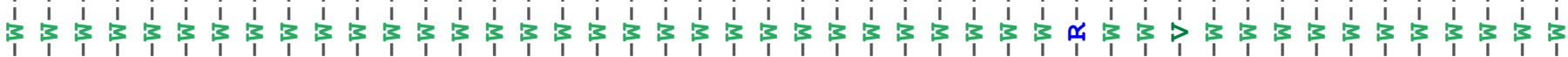

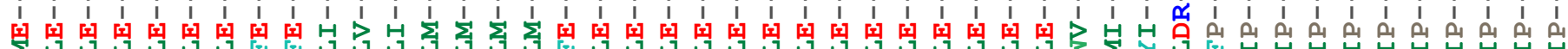

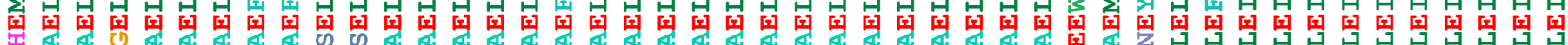

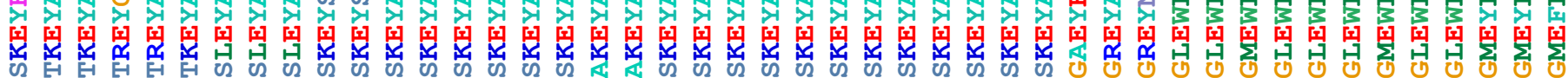

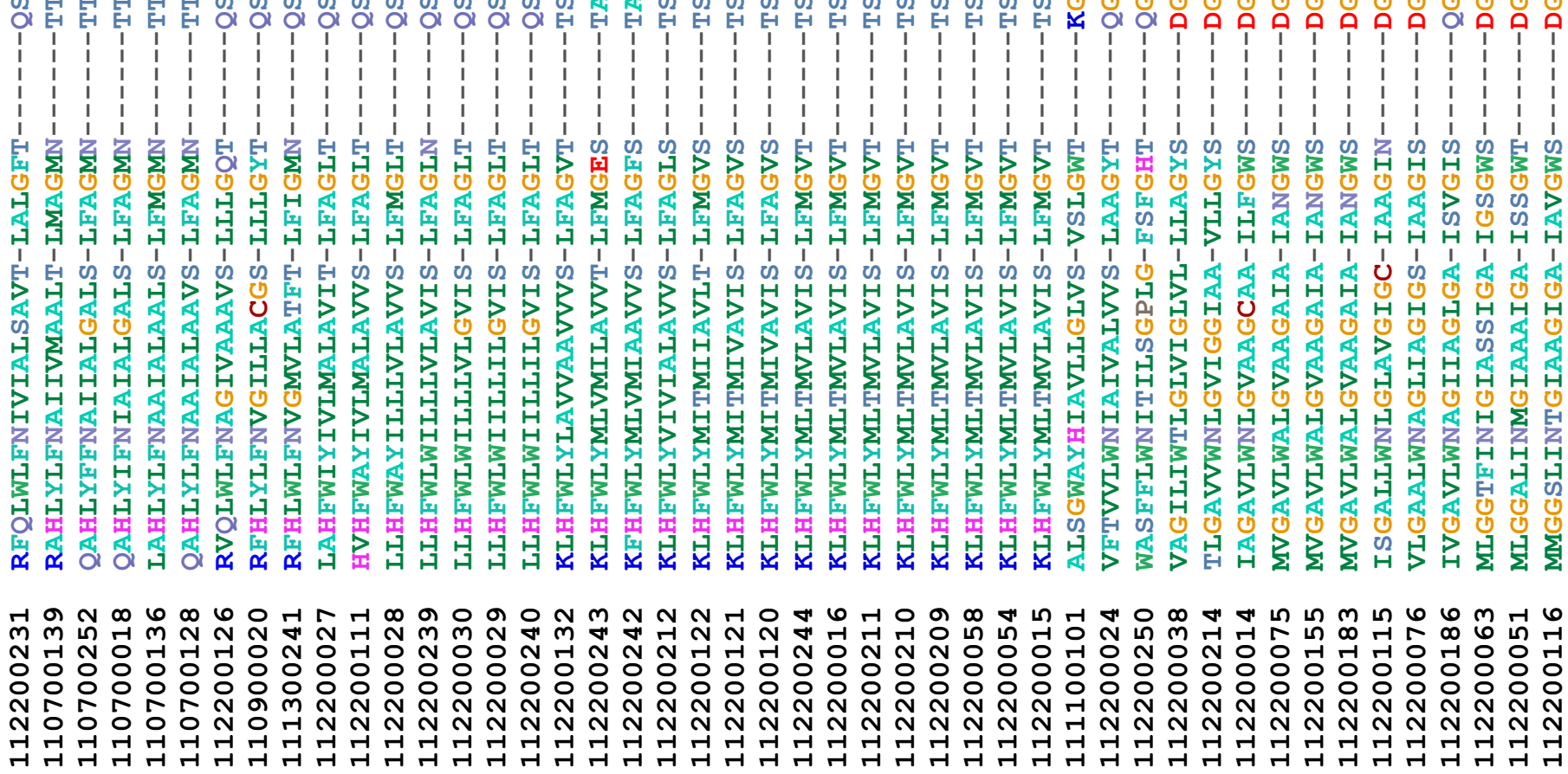




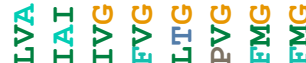

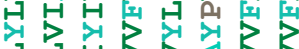

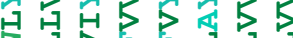

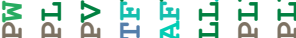

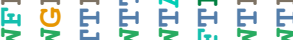

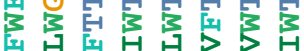

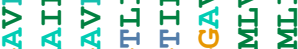

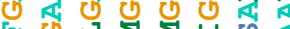

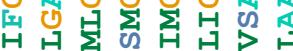

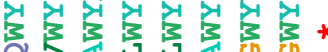

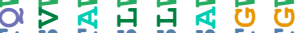

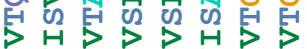

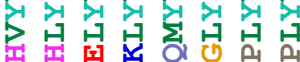

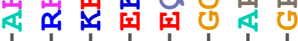

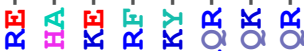
1111100

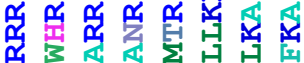
추의

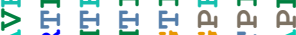

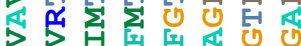

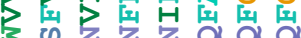

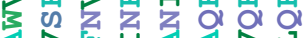

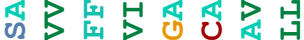

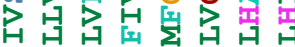
可 $\mathrm{HH}$

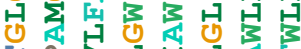

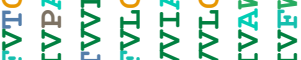

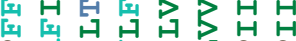

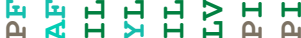

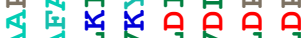

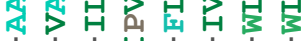
1 1 |

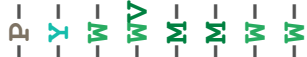

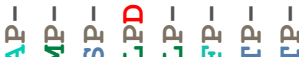

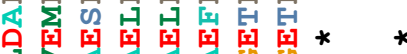

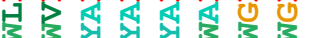

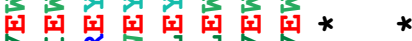

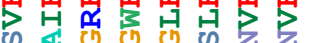

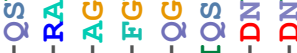


○一 -

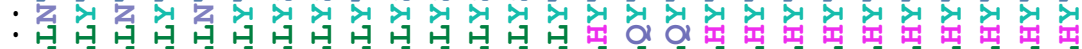

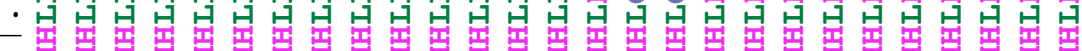

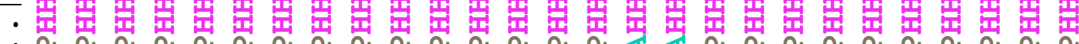

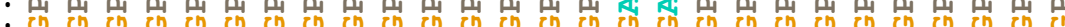
○ : . ๙

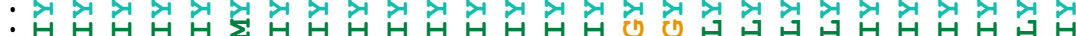

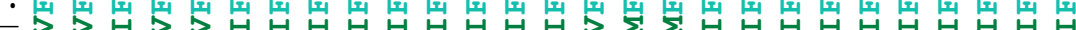

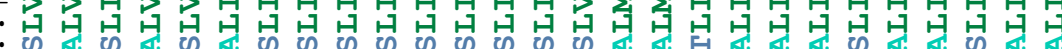

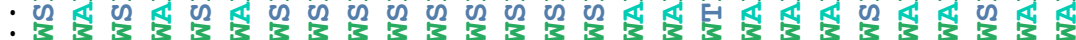

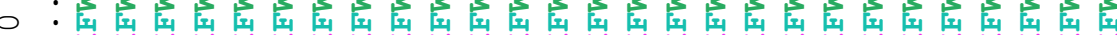

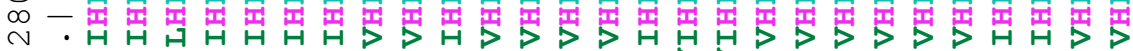

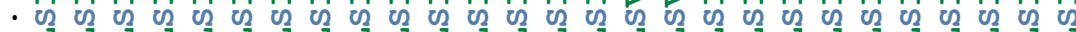

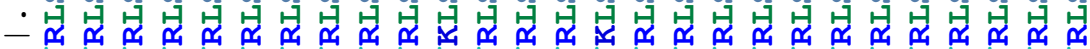

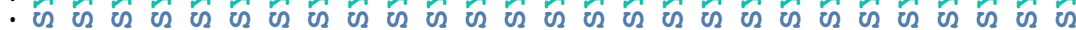

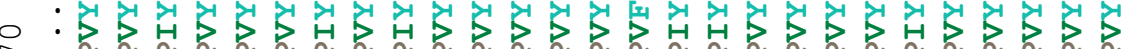

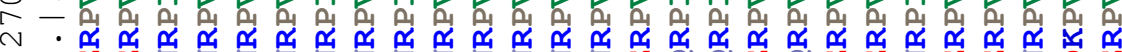

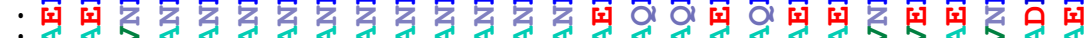

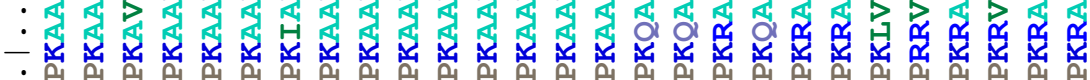

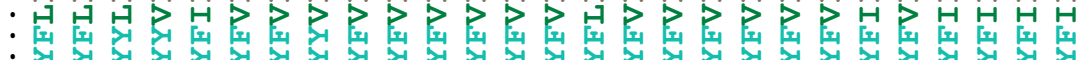
0 . ○一:

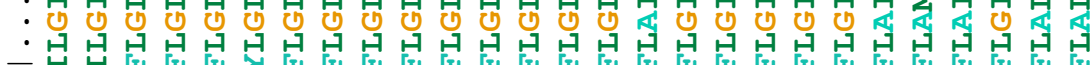

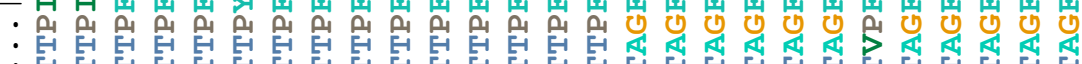

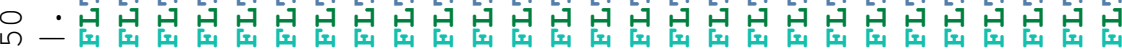
‥ $:$ 进

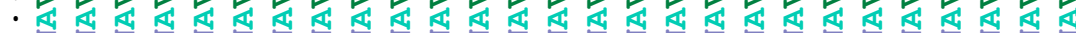

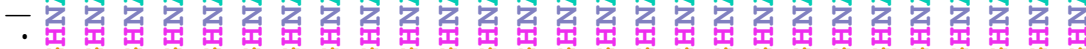

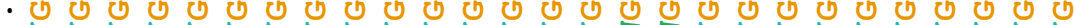

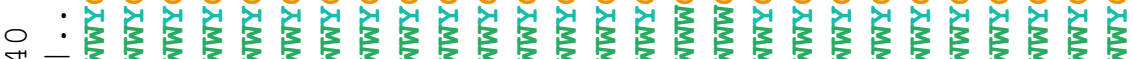

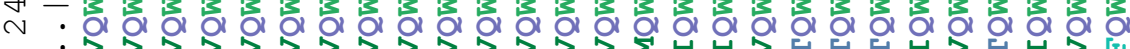

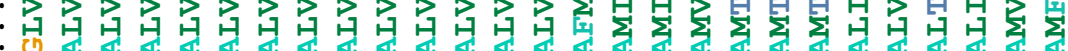

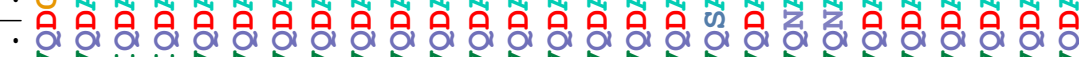

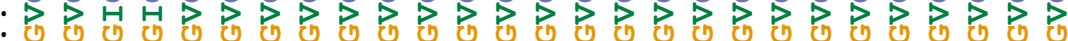

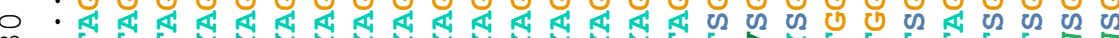

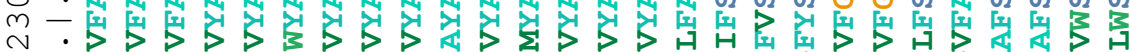

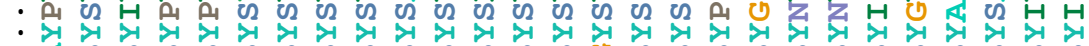
- 4 出

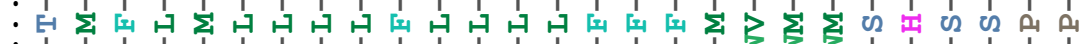

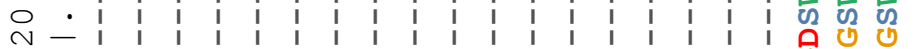

$$
\text { : }
$$$$
\div
$$$$
\text { ○ }
$$

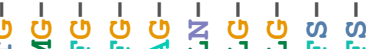

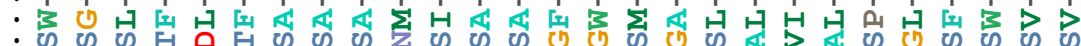

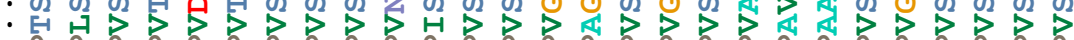

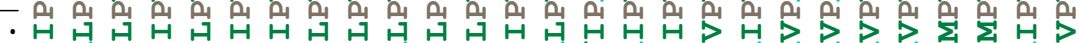

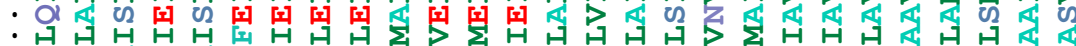

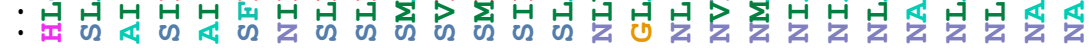

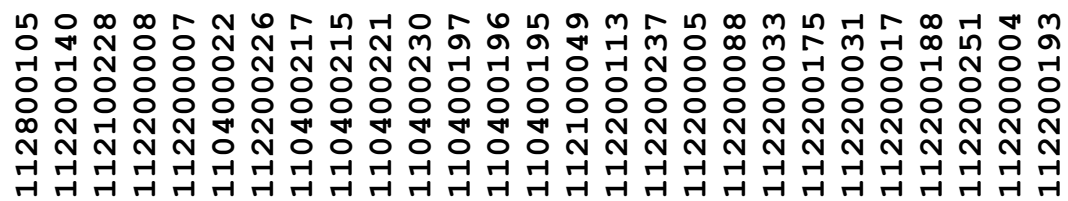




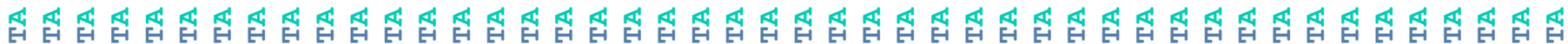

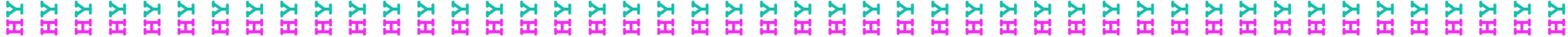

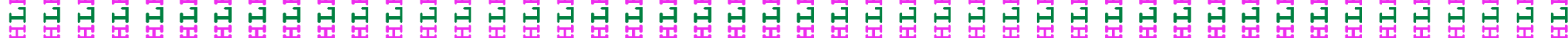

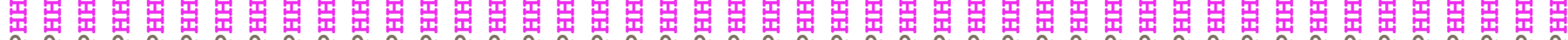

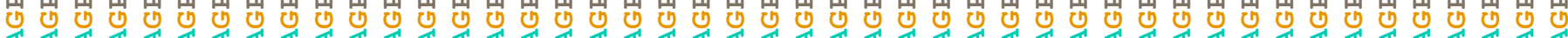

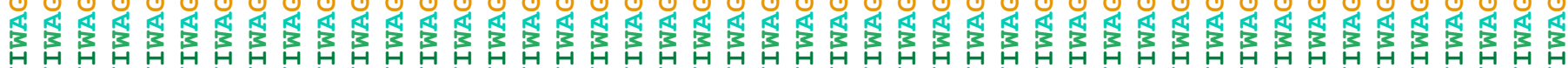

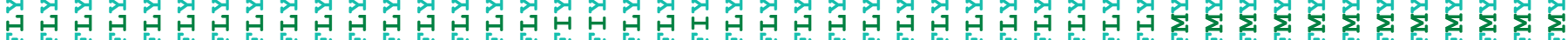

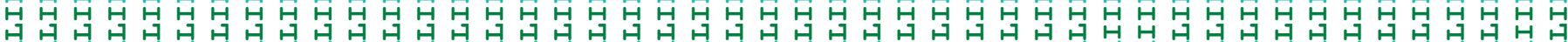

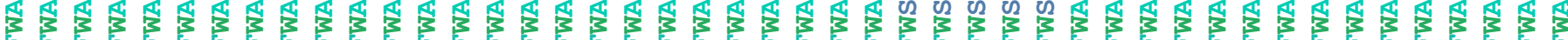

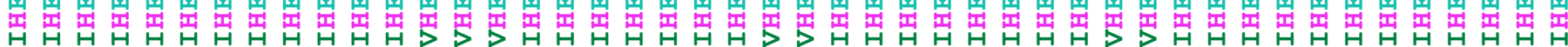

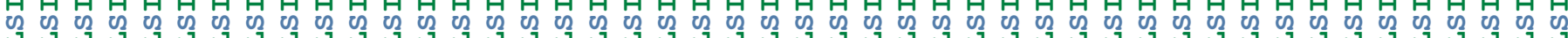

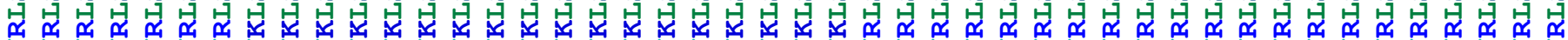

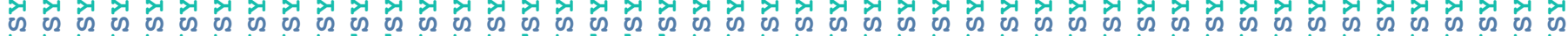

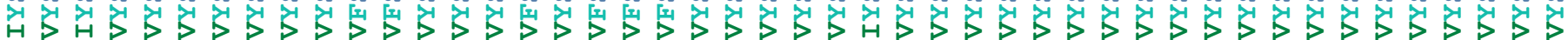

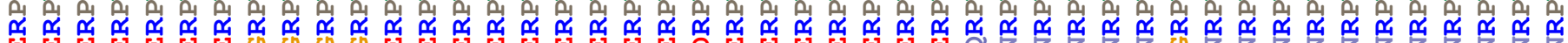

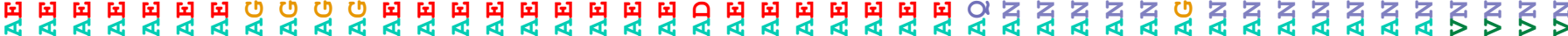

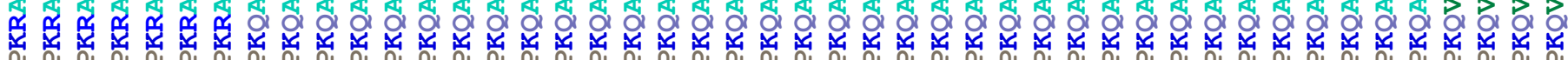

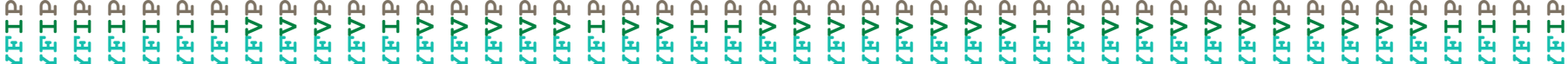

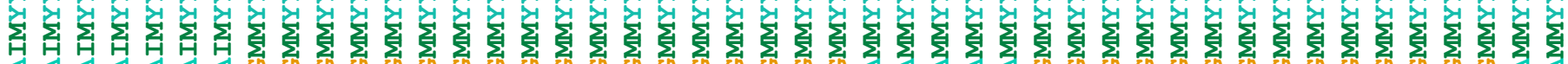

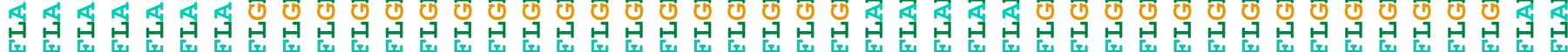

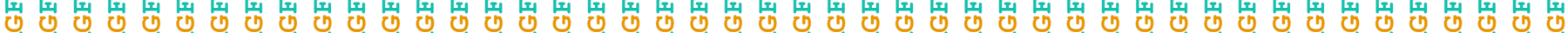

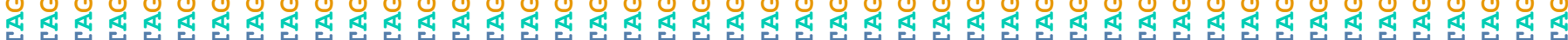

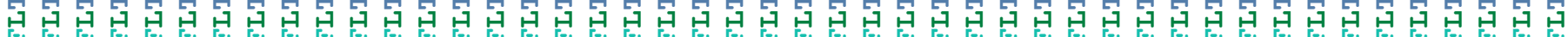

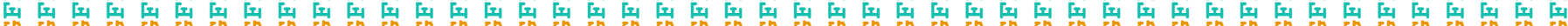

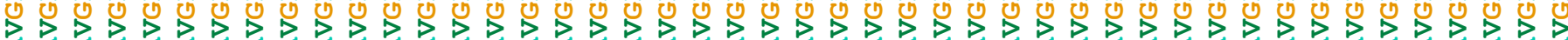

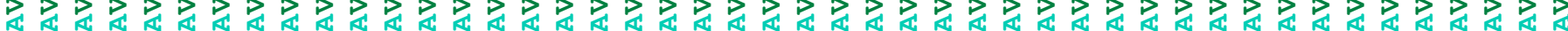

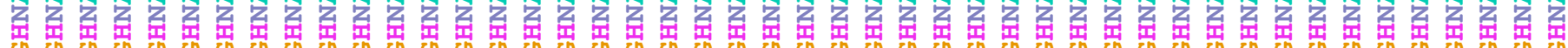
$\bigcup_{x=1} \underbrace{}_{x}$

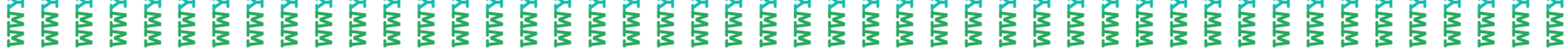

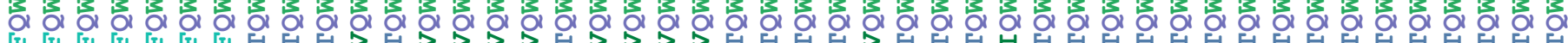

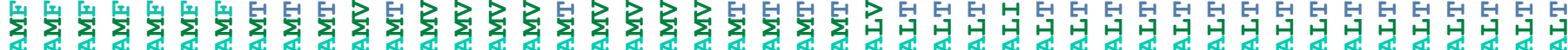

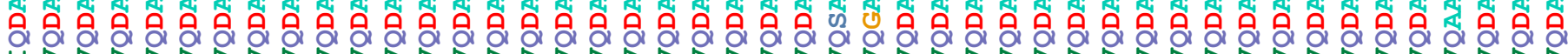

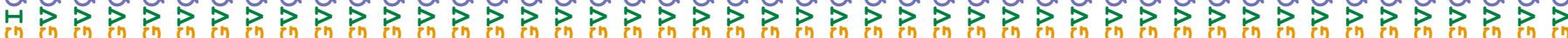
Uण Uण

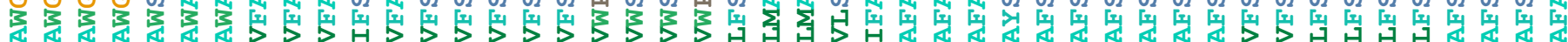

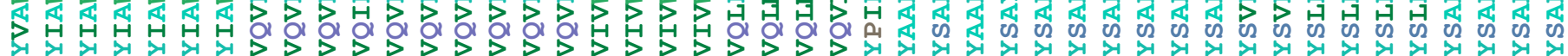

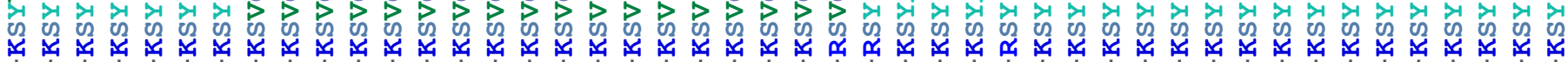

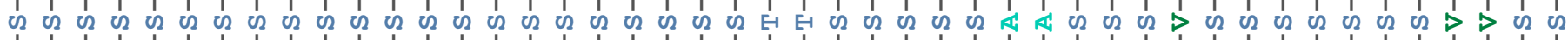

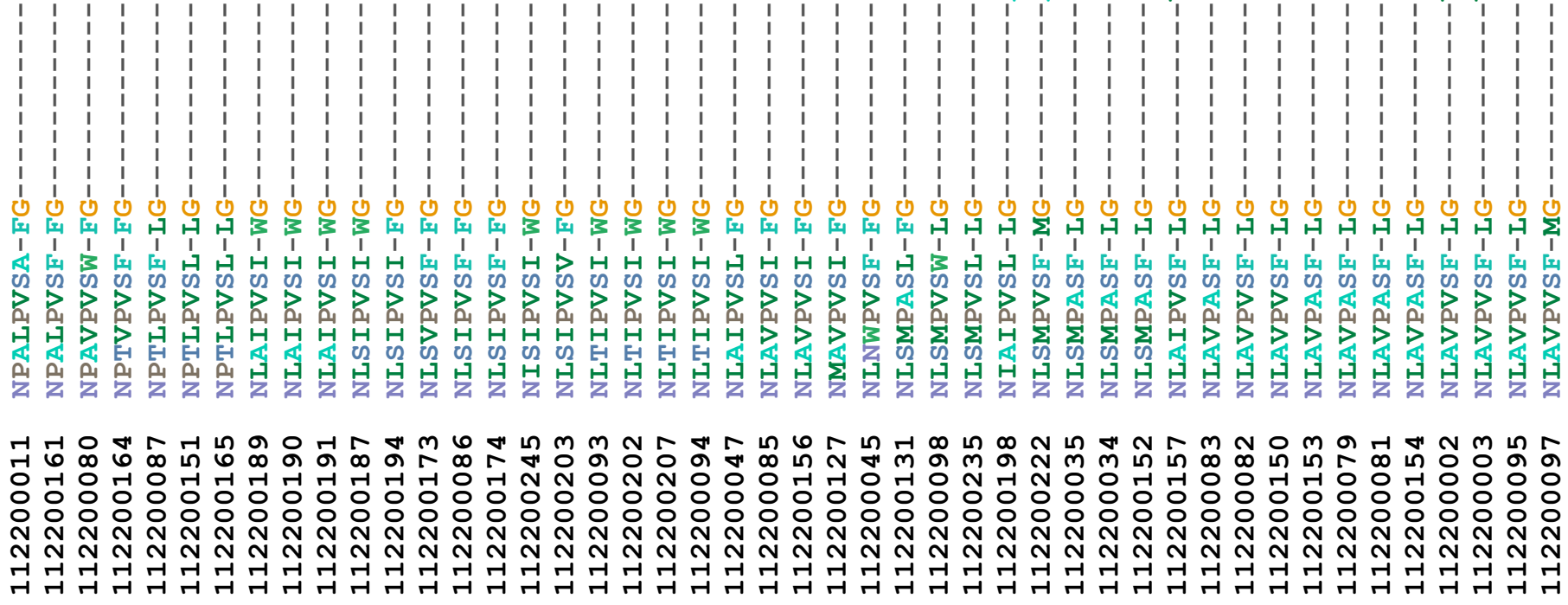




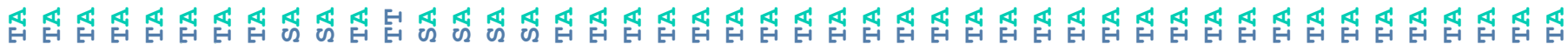

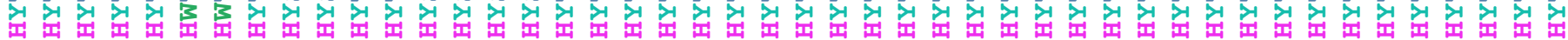

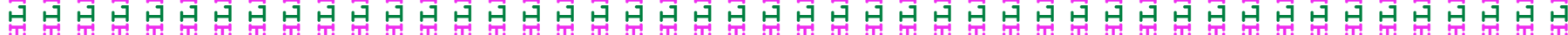

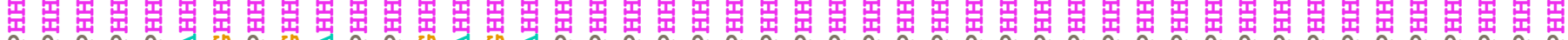

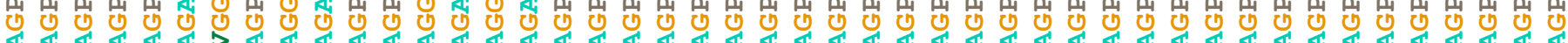

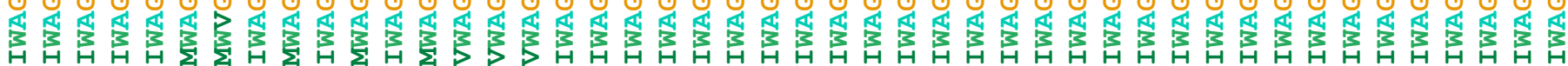

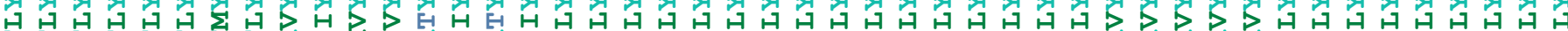

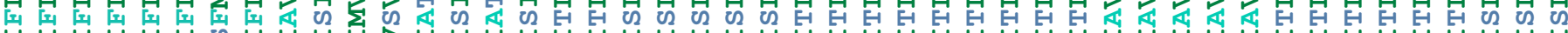

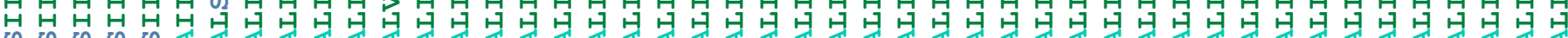

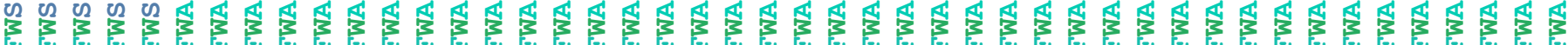

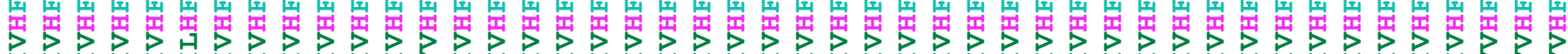

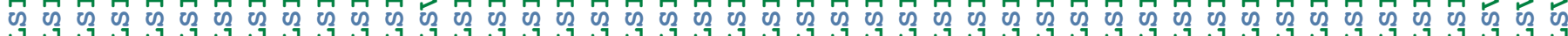

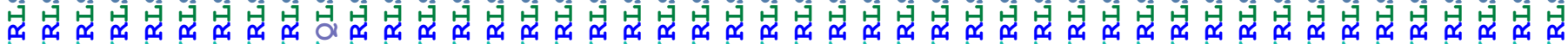

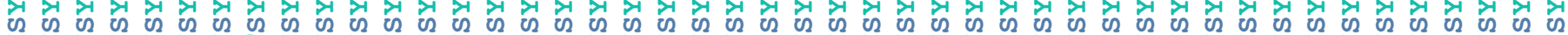

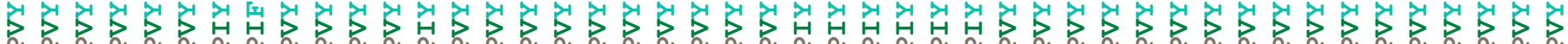

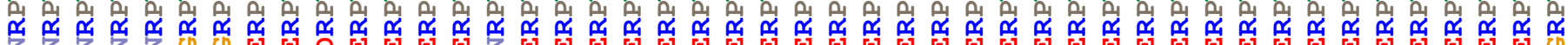

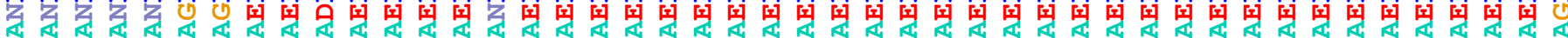

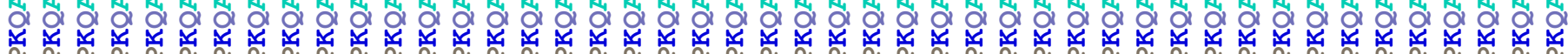

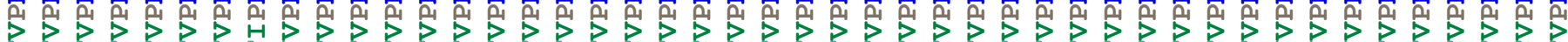

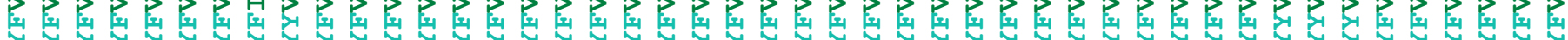

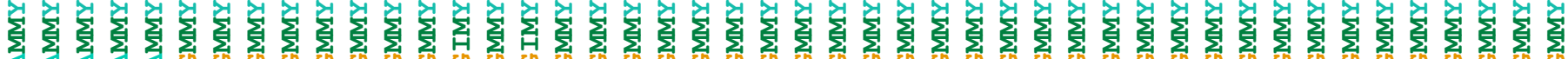

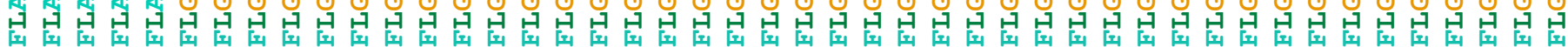

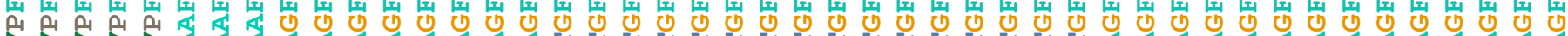

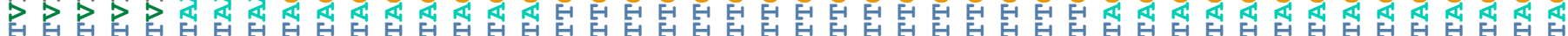

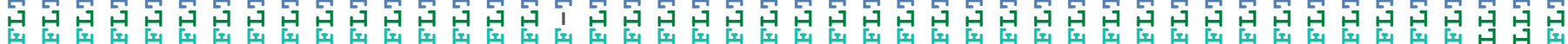

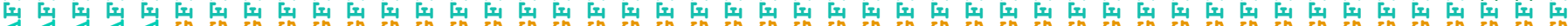

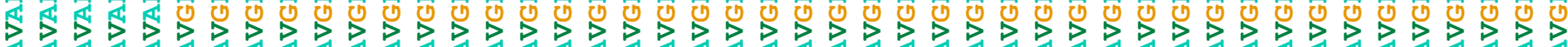

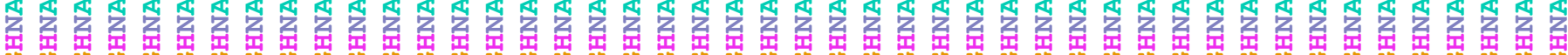

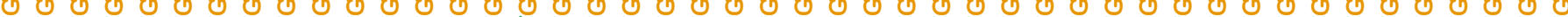

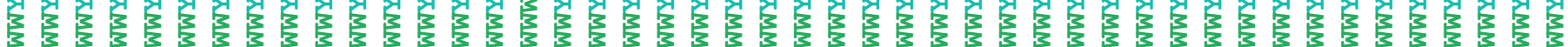

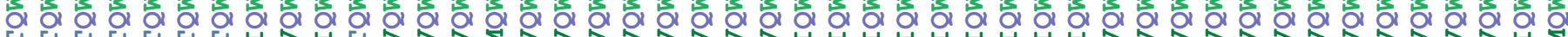

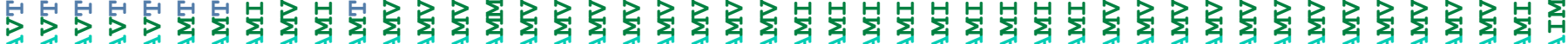

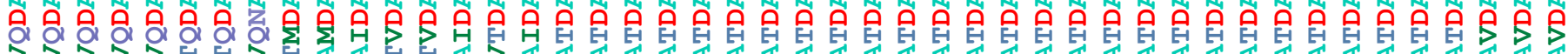

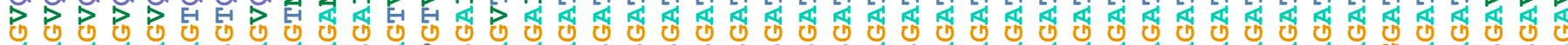

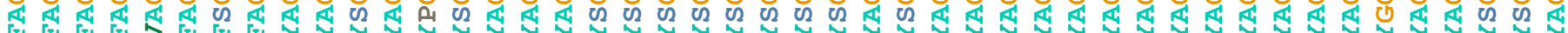

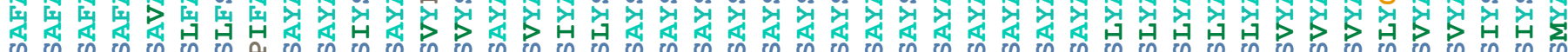
2202020

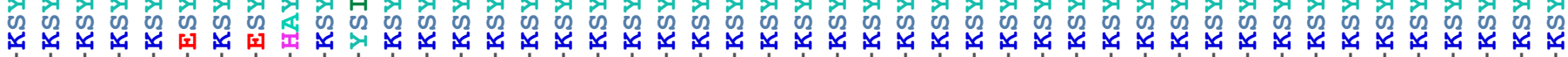

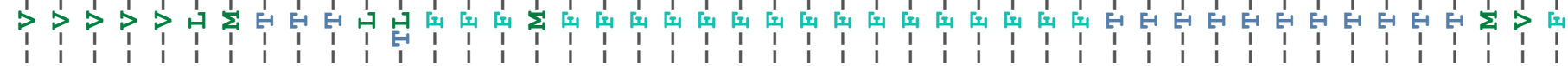

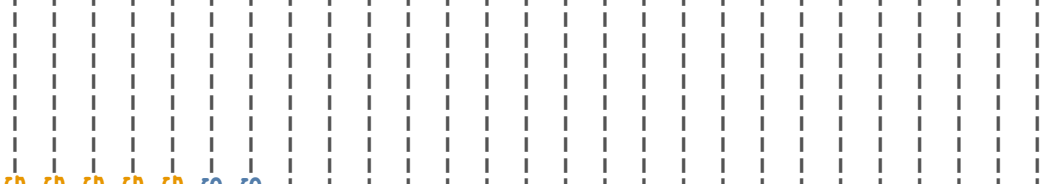

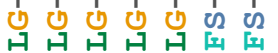

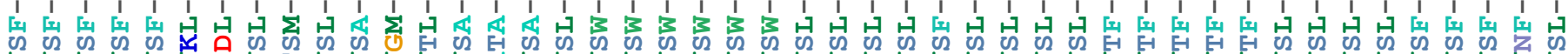

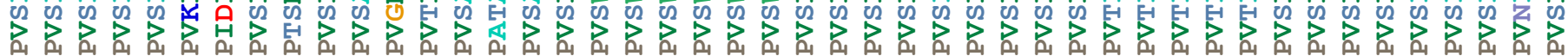

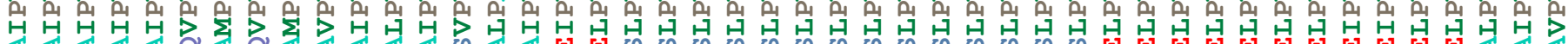

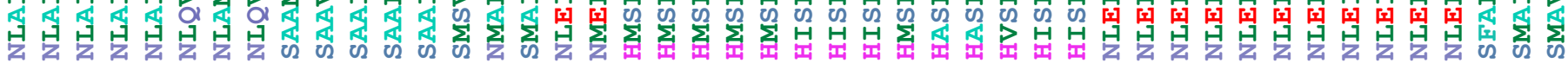

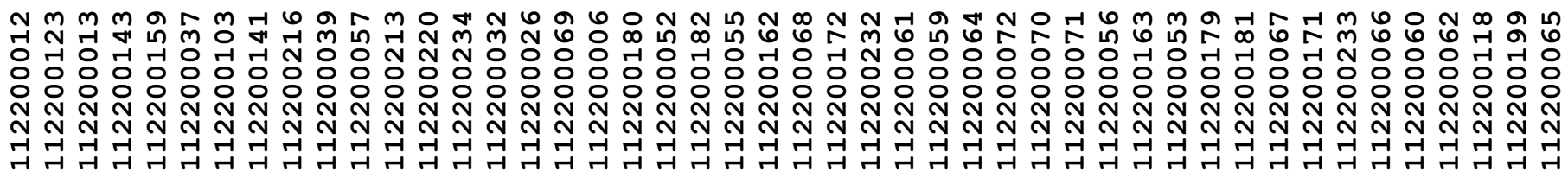




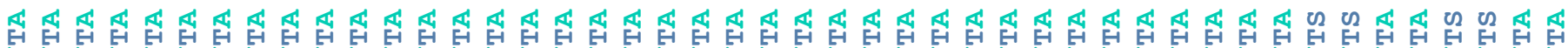

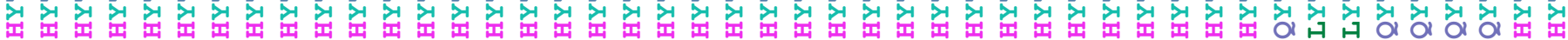

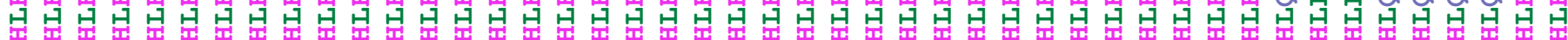

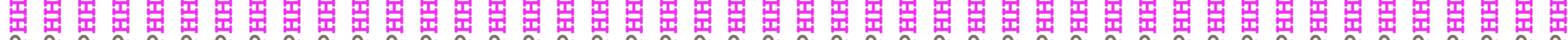

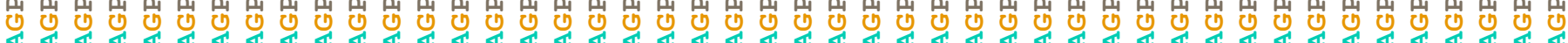

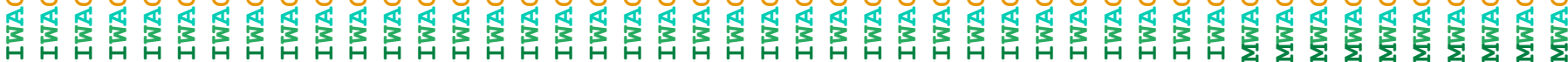

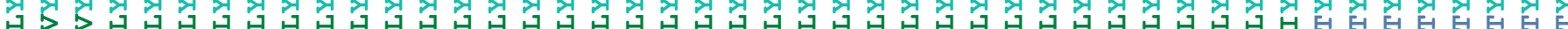

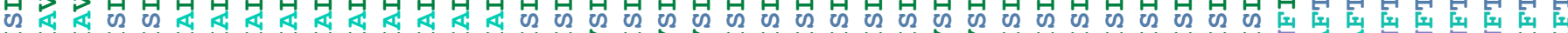

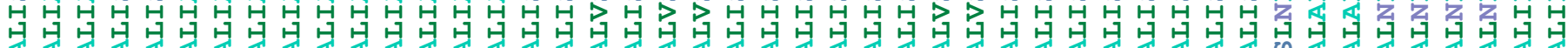

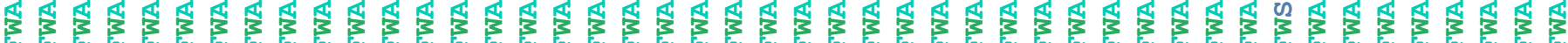

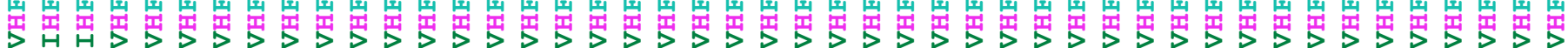

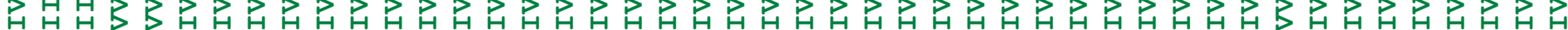

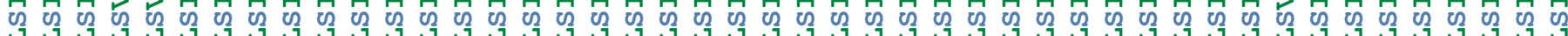

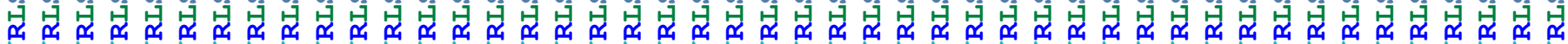

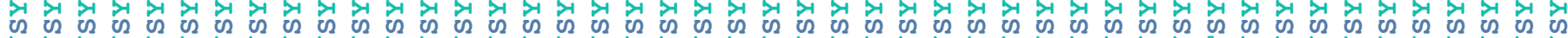

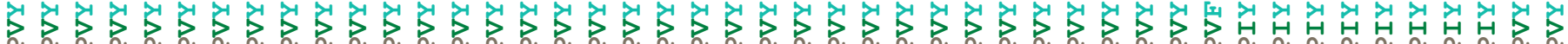

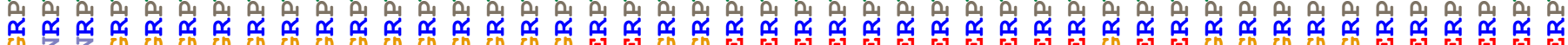

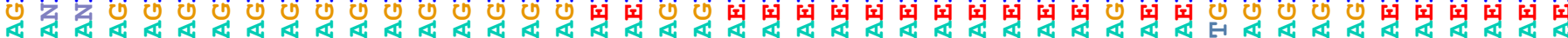

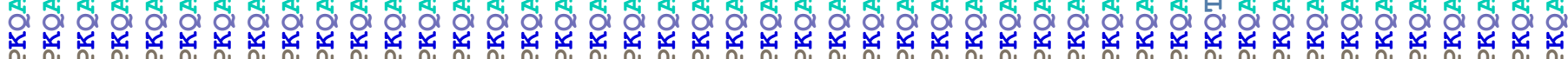

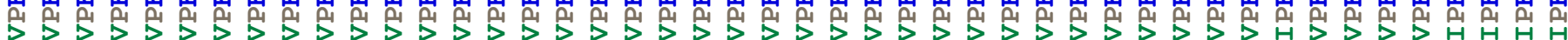

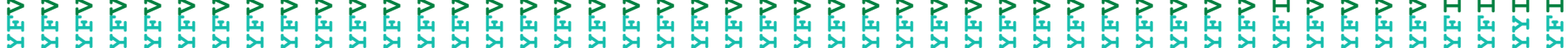

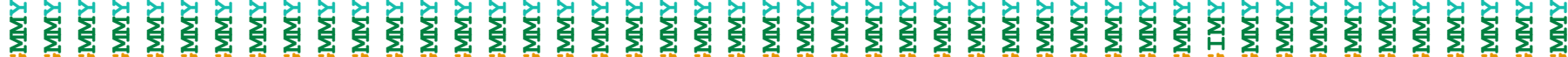

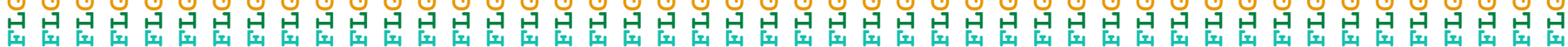
岳

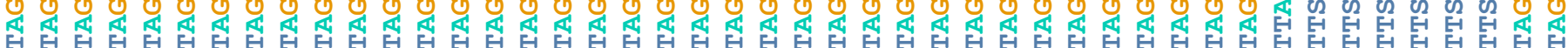

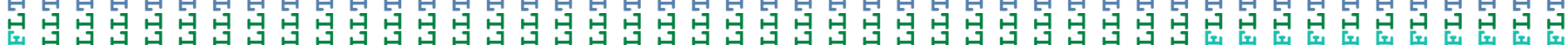

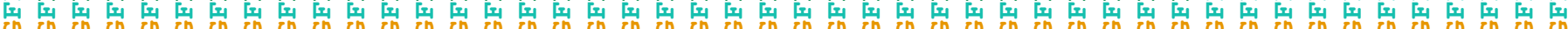

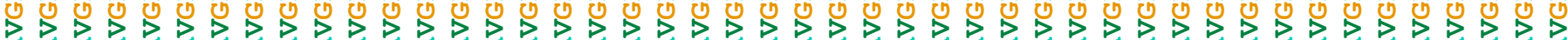

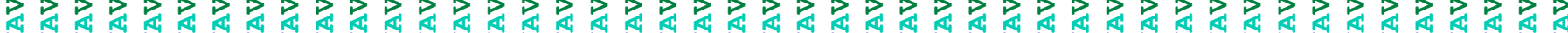

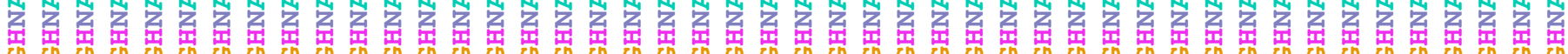
$\bigcup_{x}$

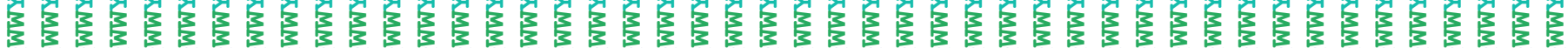

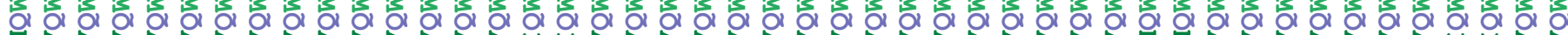

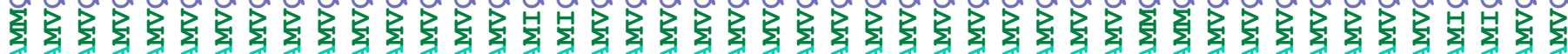

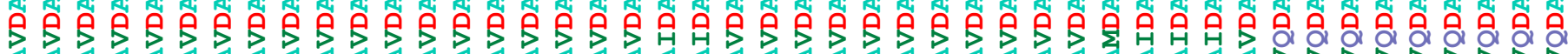

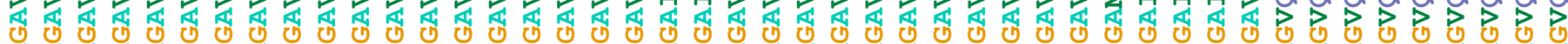

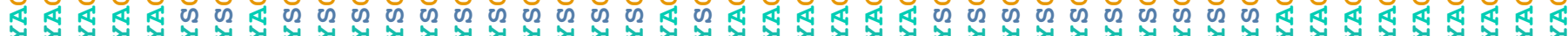

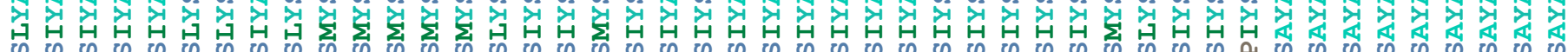

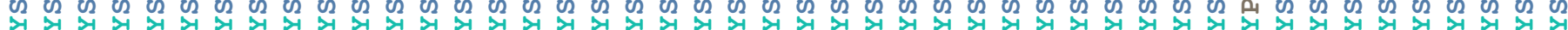

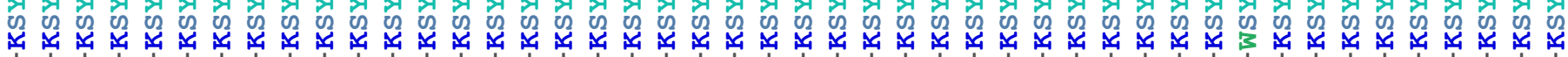

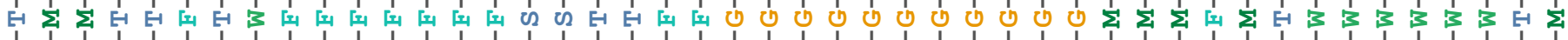

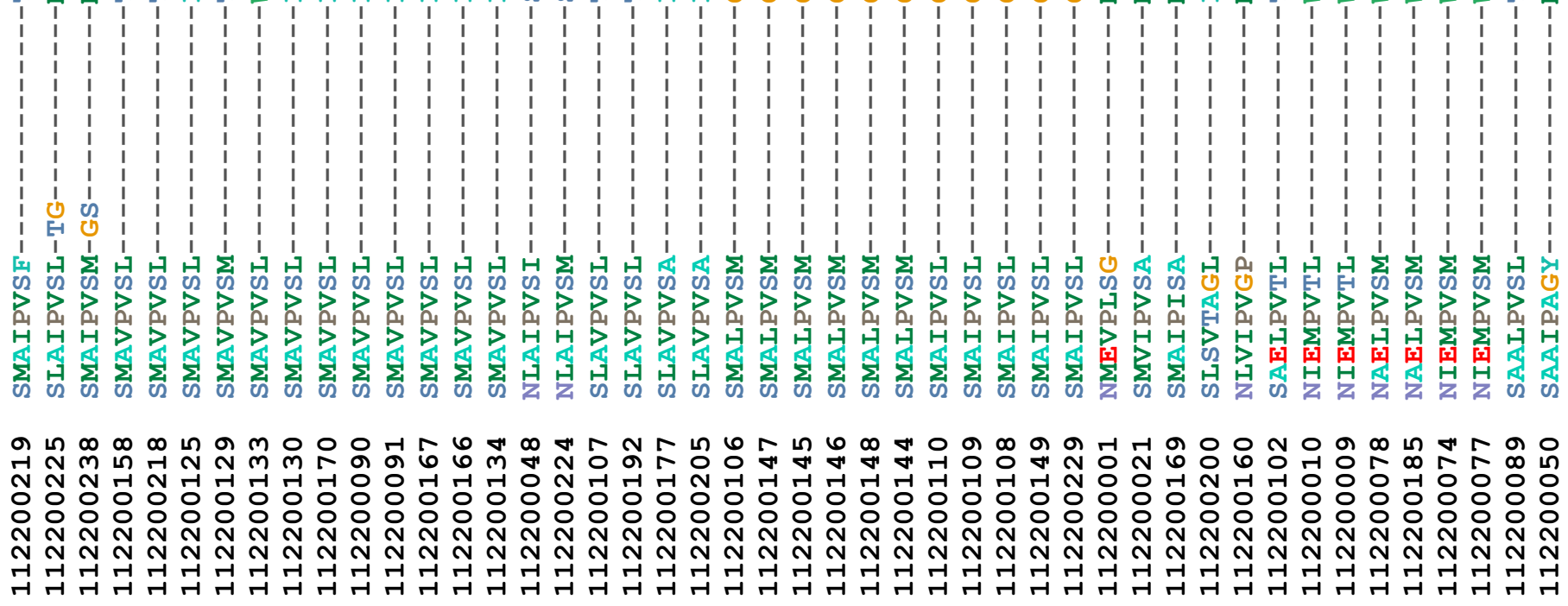




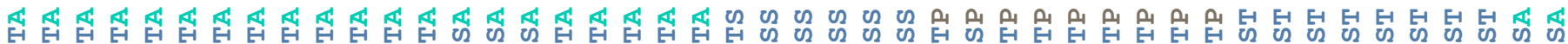

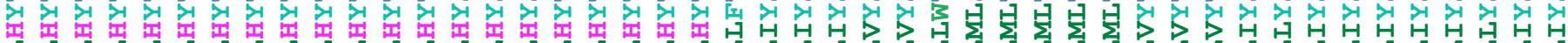

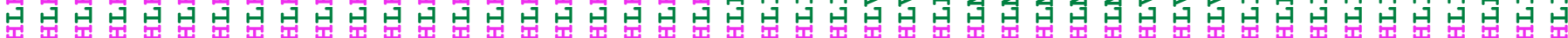

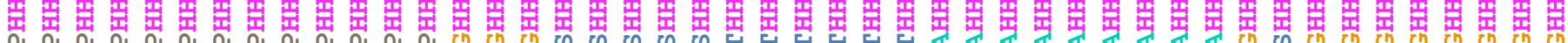
0

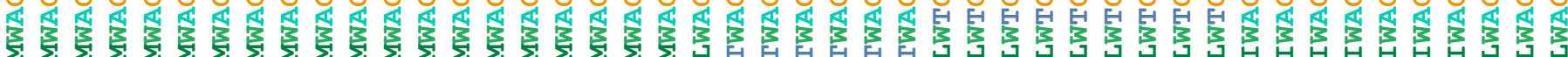

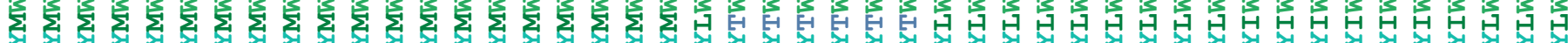

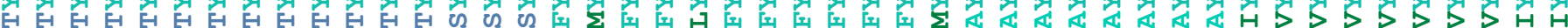

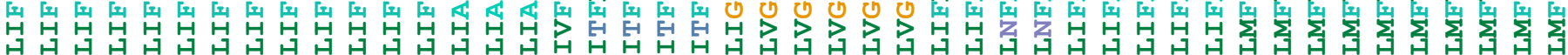

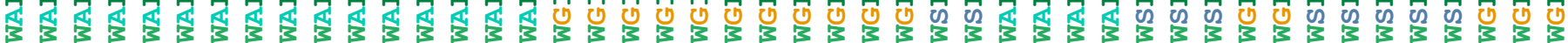

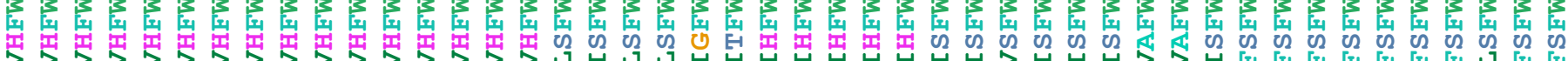

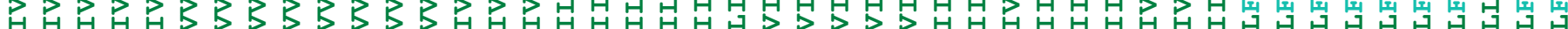

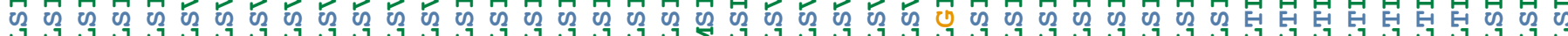

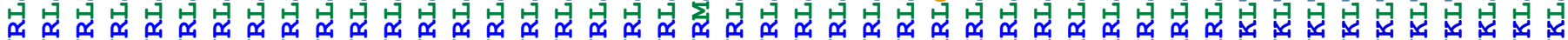

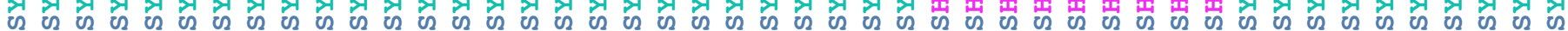

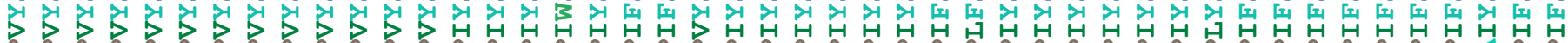

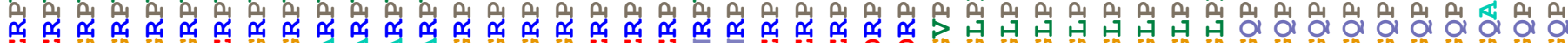

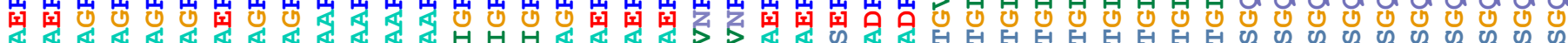

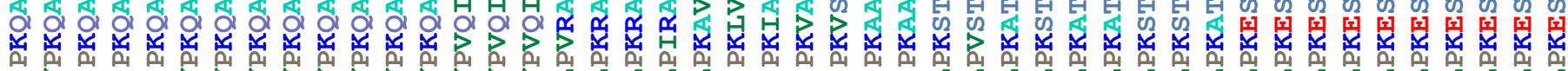

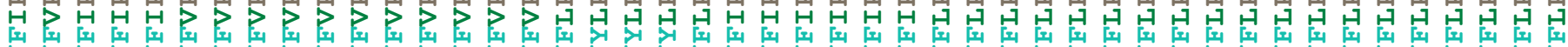

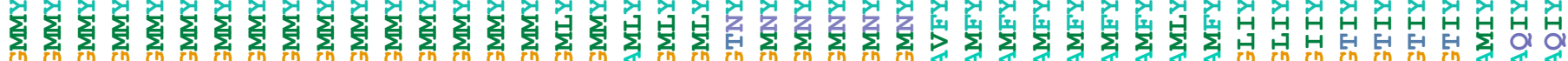

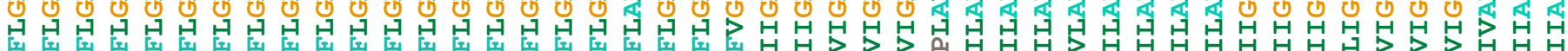

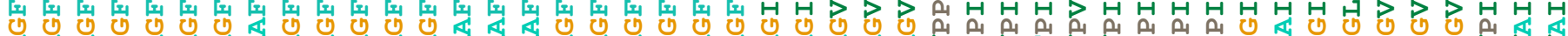

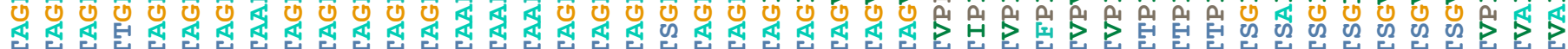

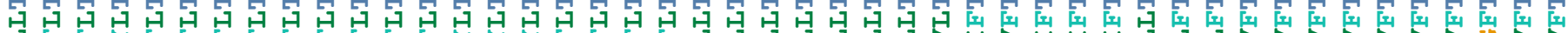

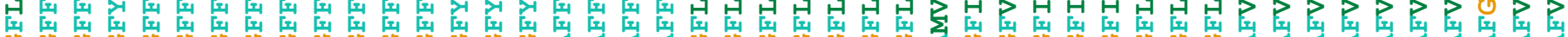

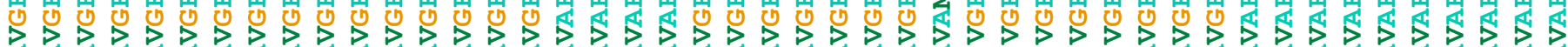

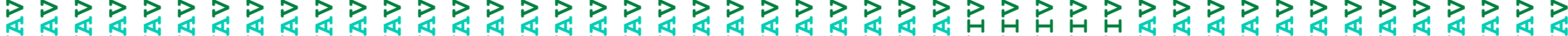

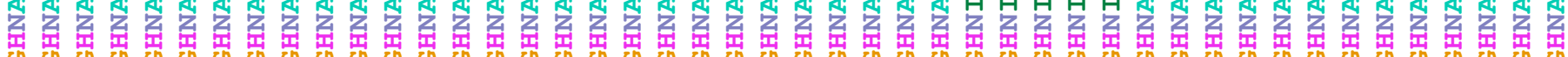

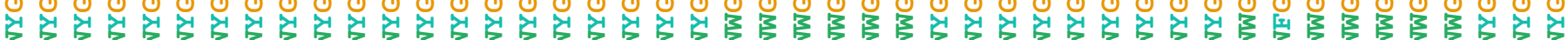

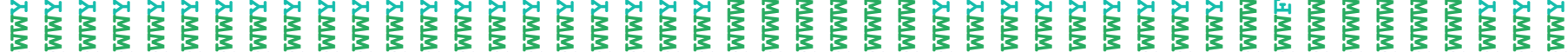

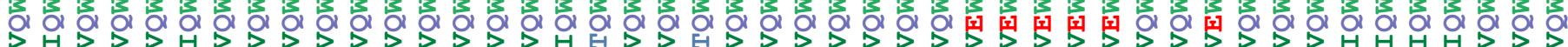

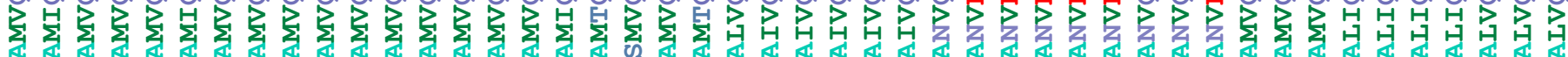

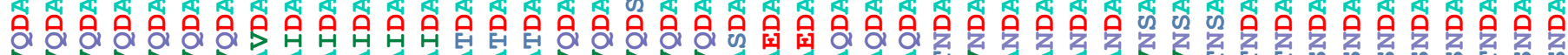

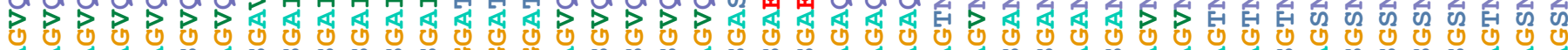

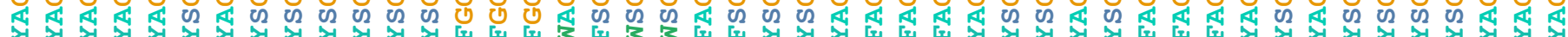

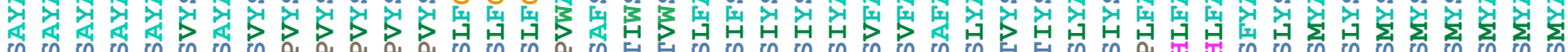
记

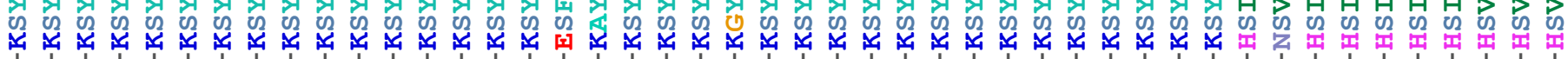

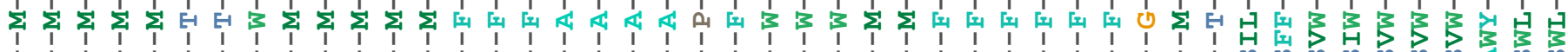

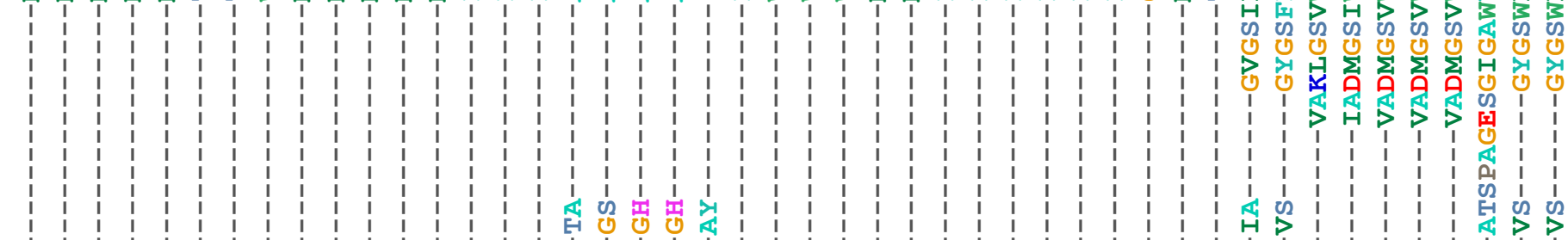

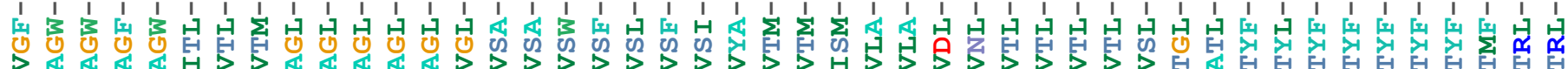

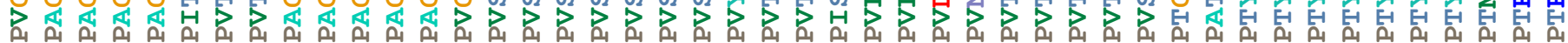

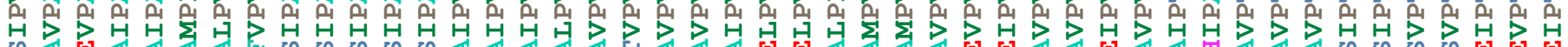

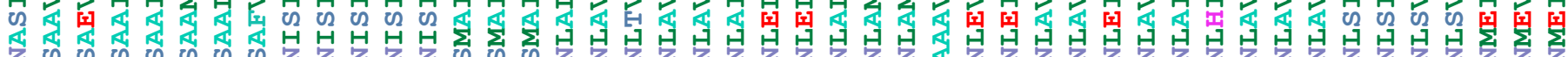

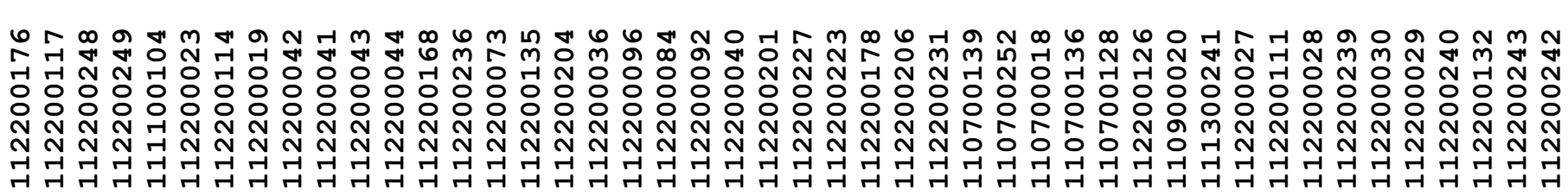




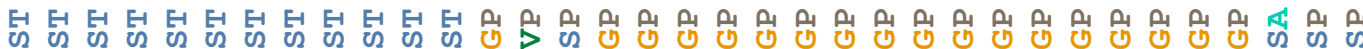

$\bigcirc$

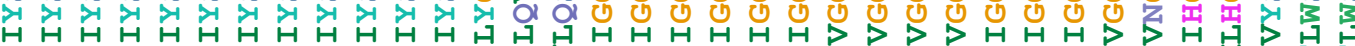

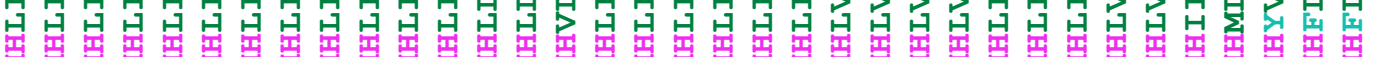

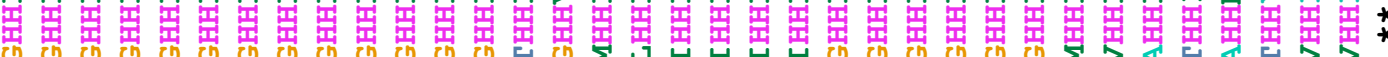

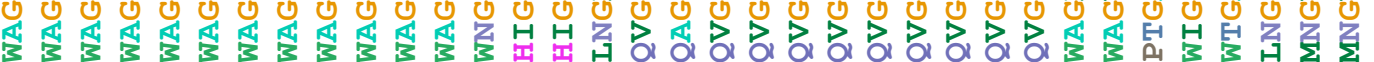

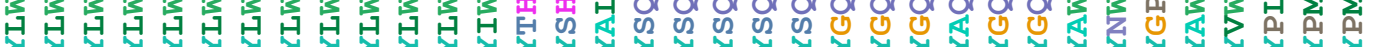

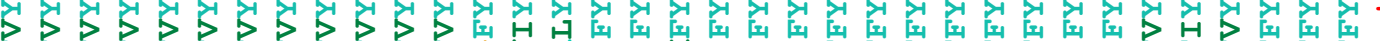

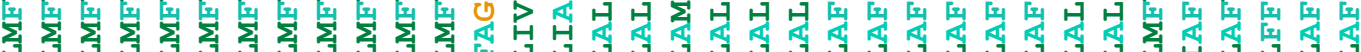

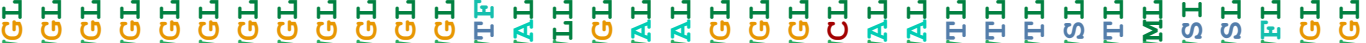

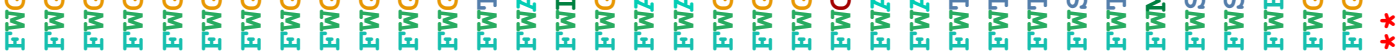

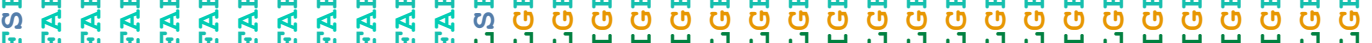

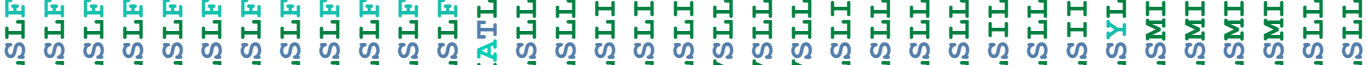

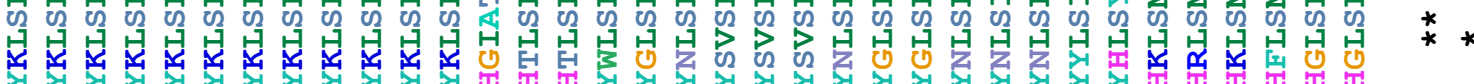

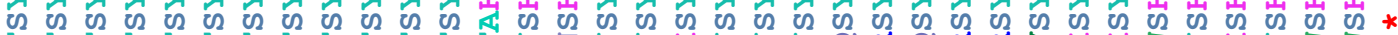

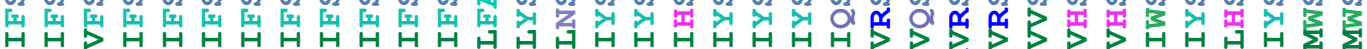

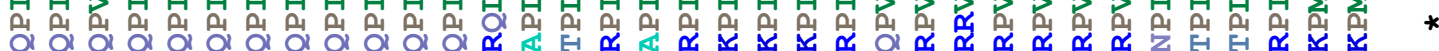

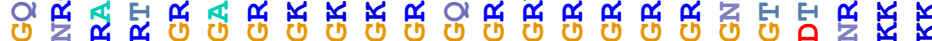

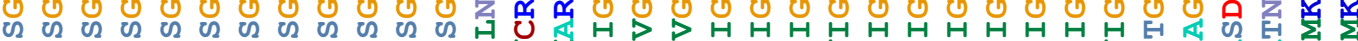

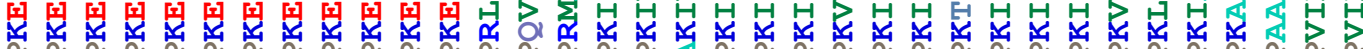

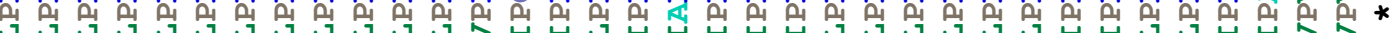

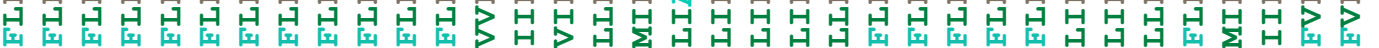

त्रत्र

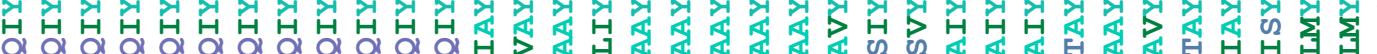

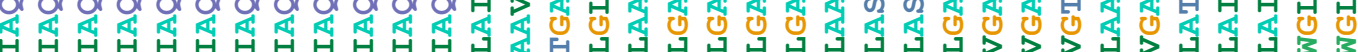

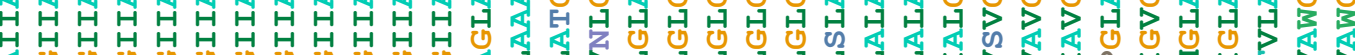

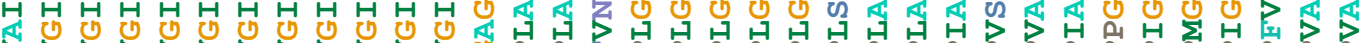

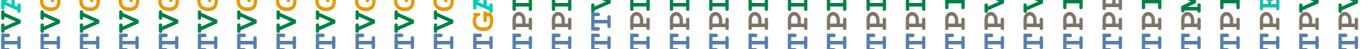

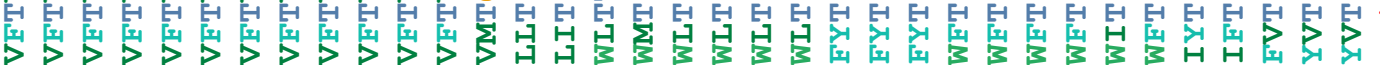

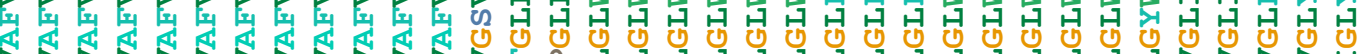

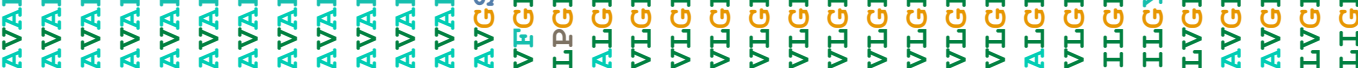

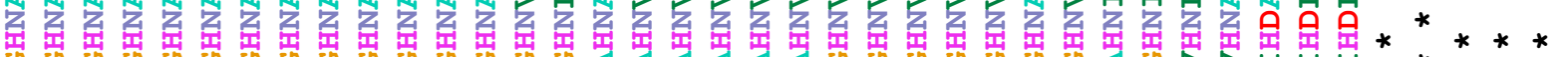

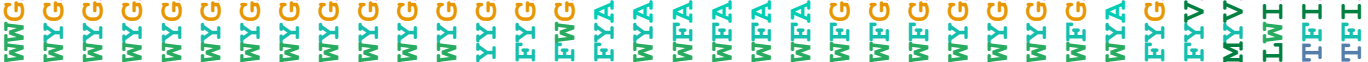

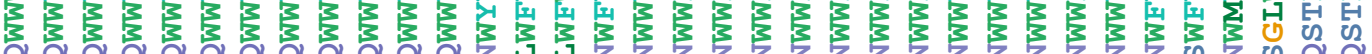

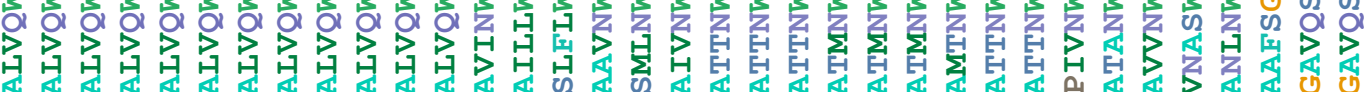

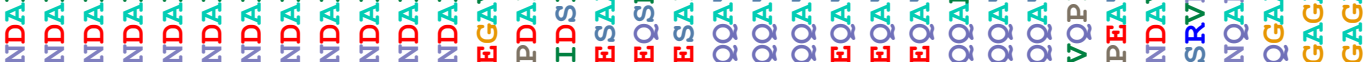

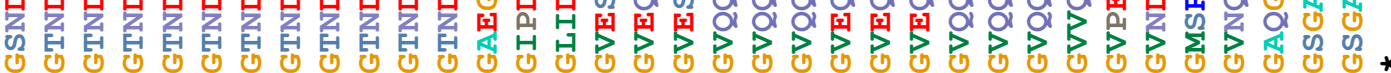

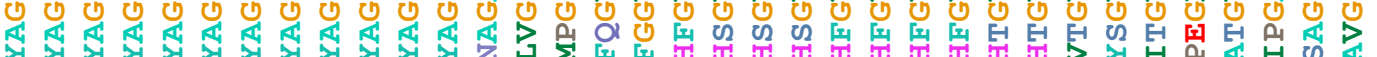

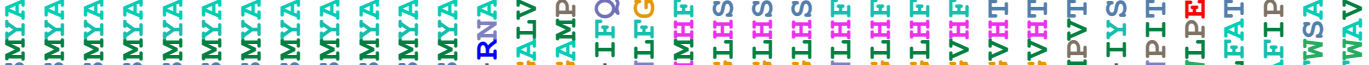

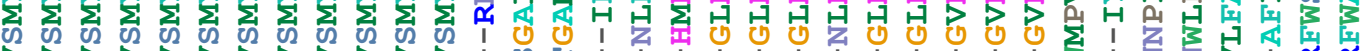

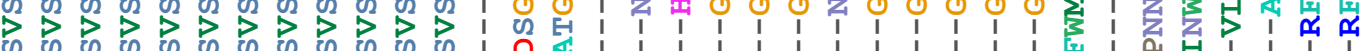

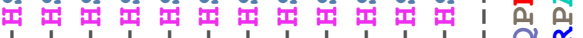

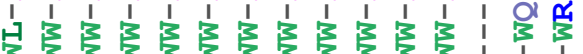

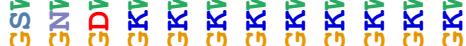

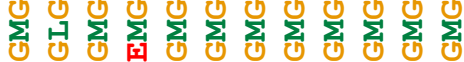

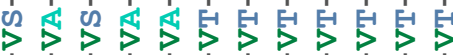

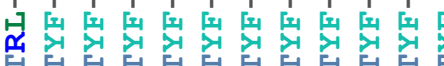

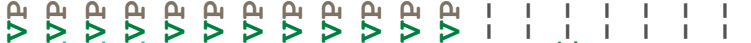

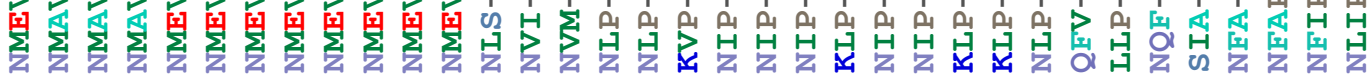

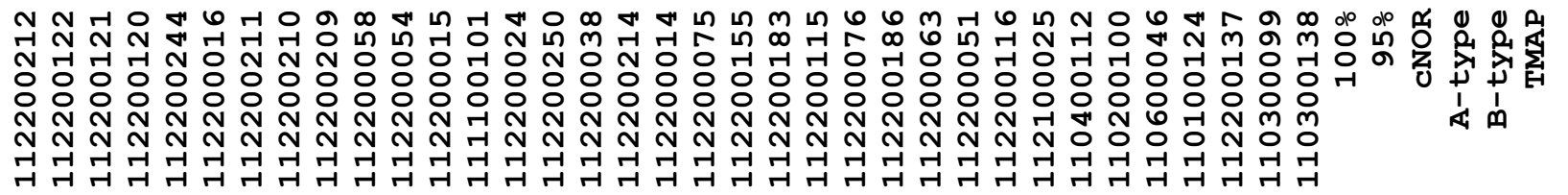




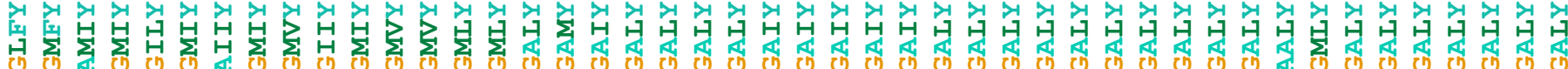

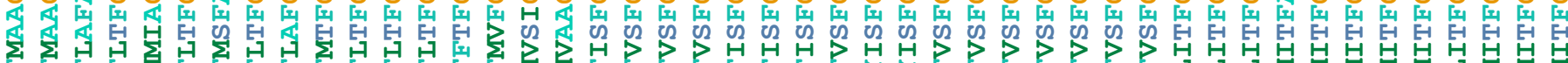

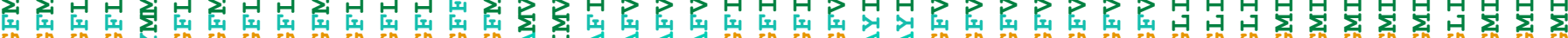

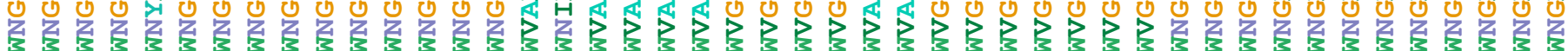

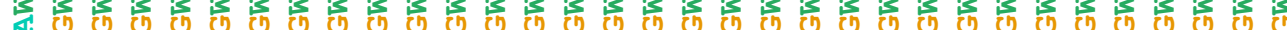

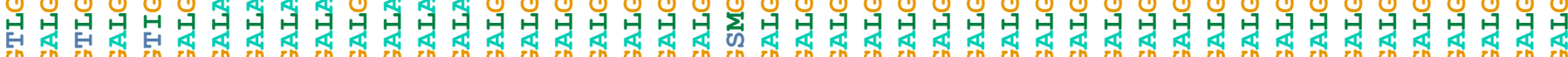
D

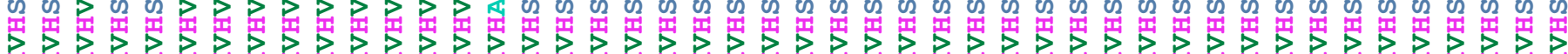

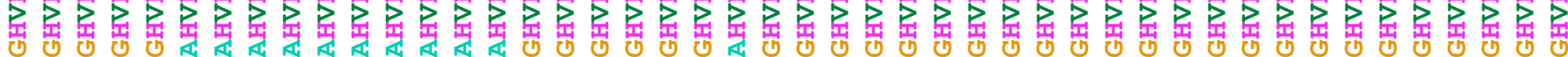

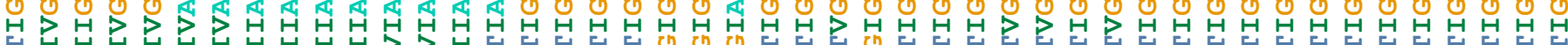

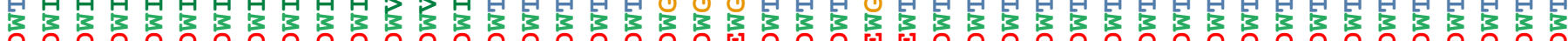

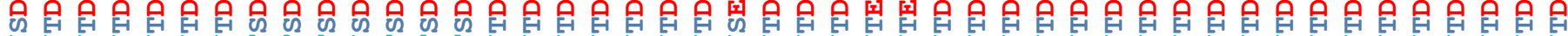

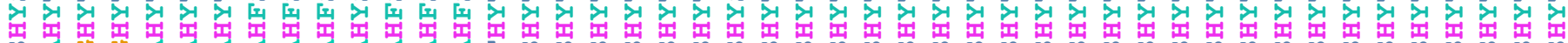

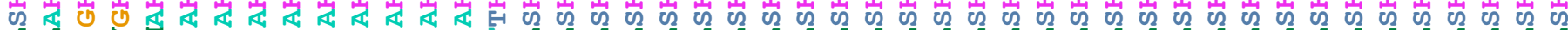

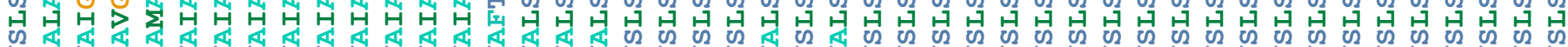

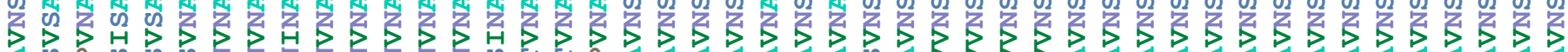

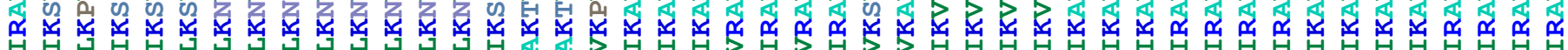

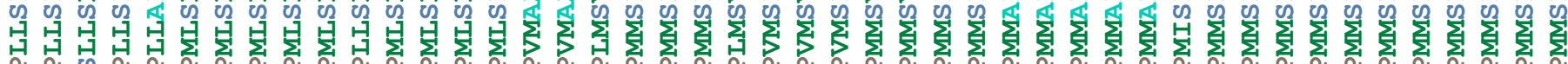

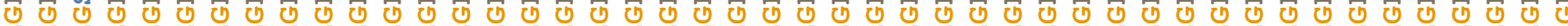

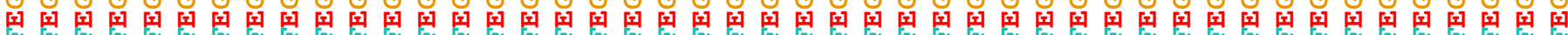

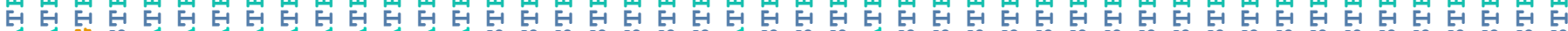

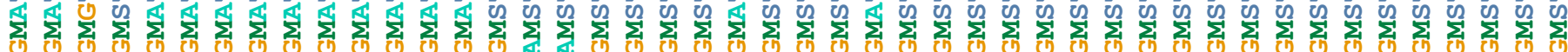

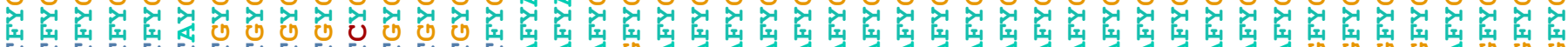

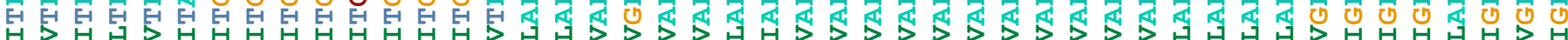

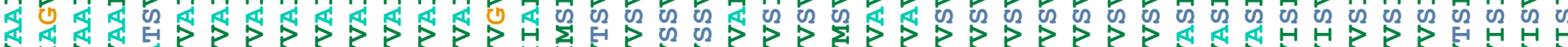

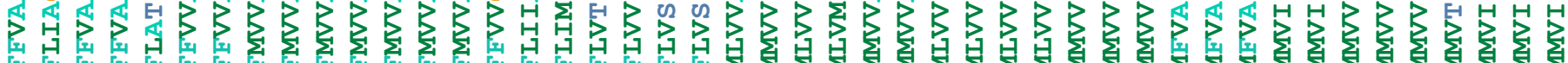

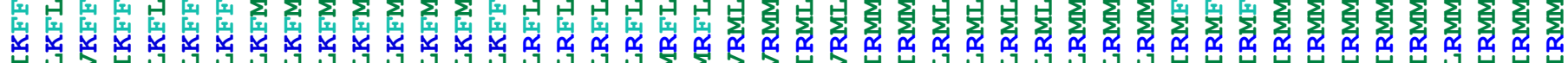

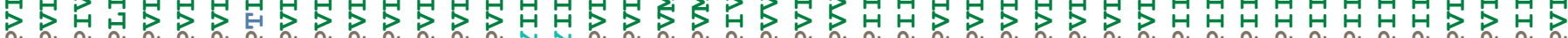

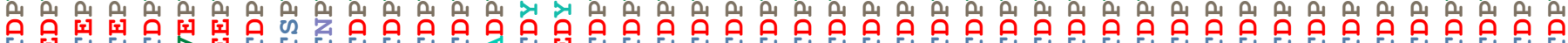

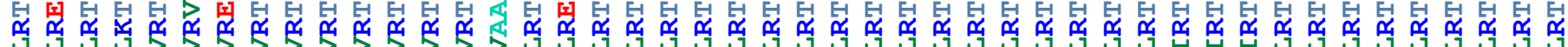

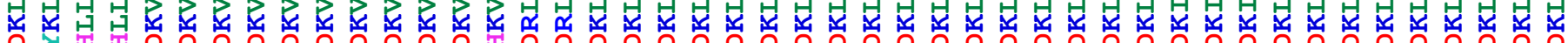

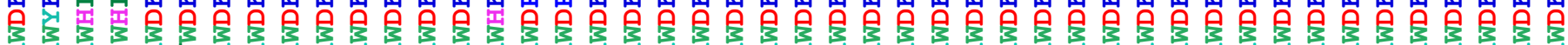

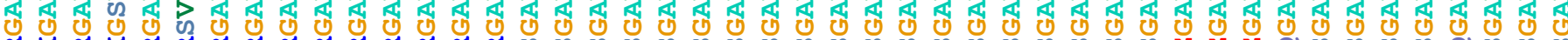

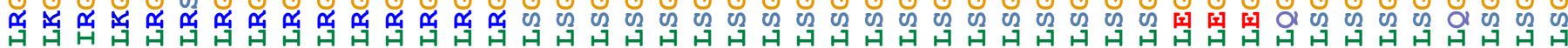

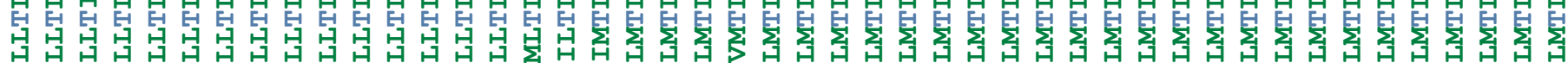

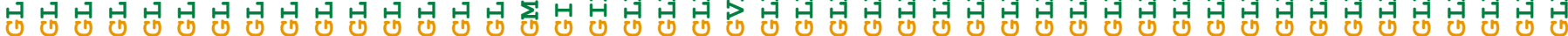

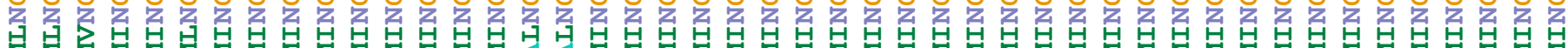

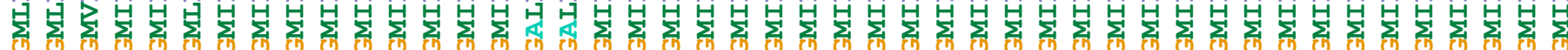

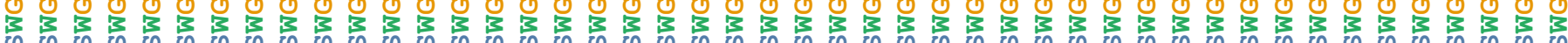

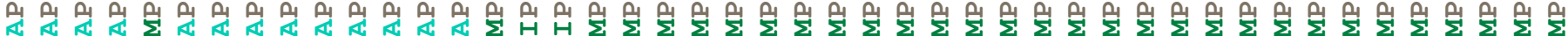

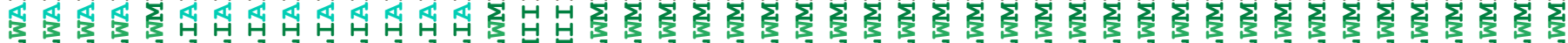

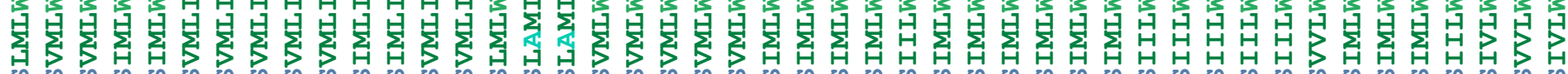

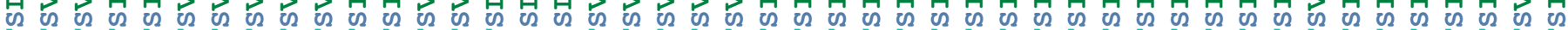

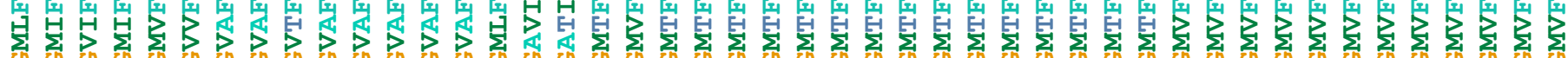

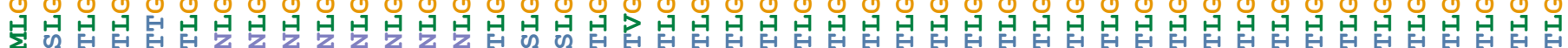

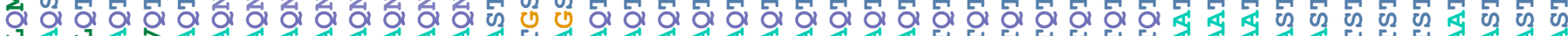

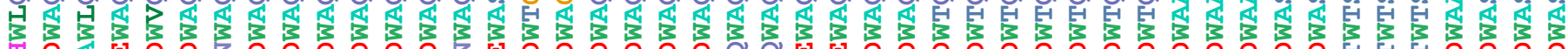

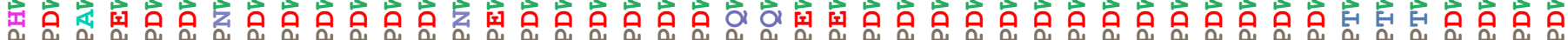

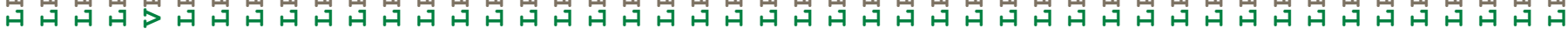

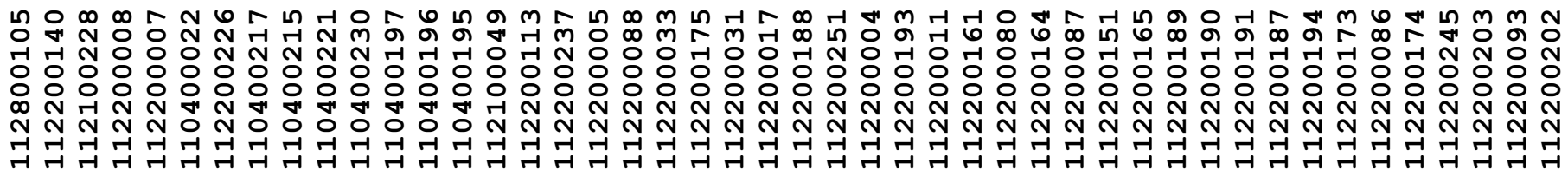




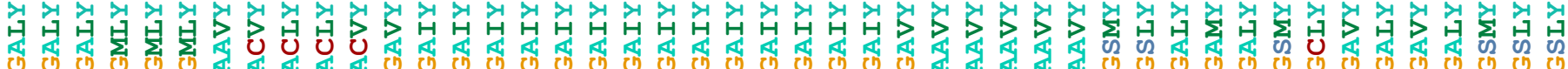

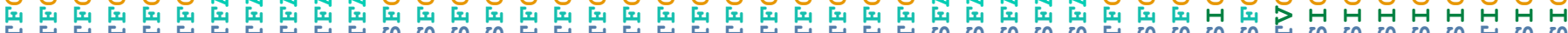

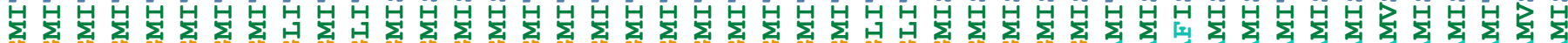

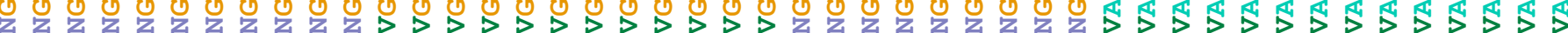

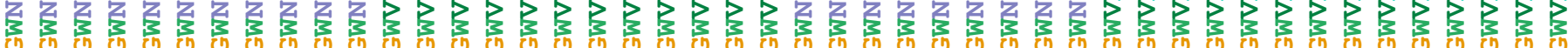
н Uె口

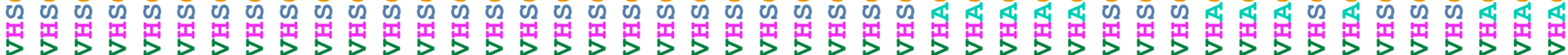

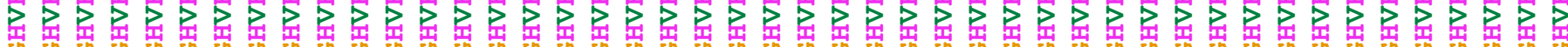
H H H H H H H H H H H H H H H H H H H H P S H H H P H H H

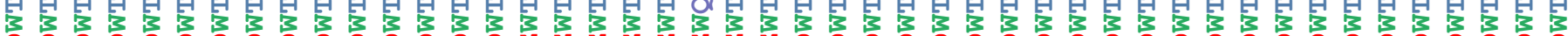

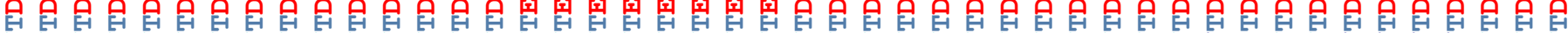

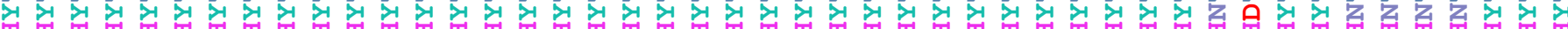

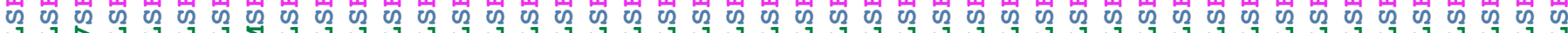

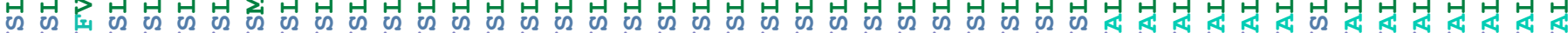

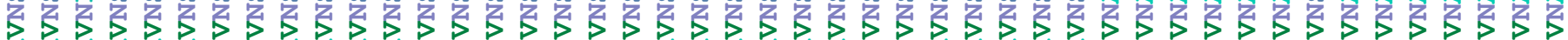

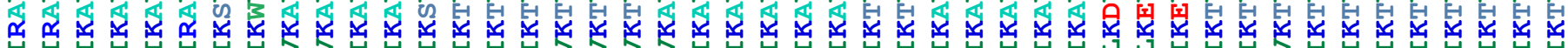

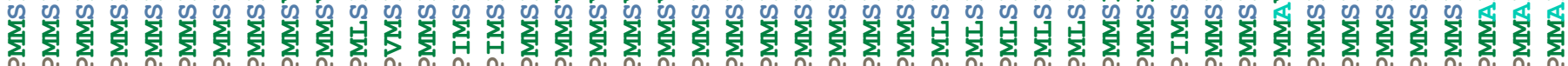

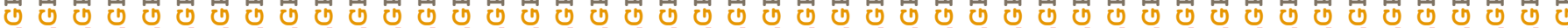

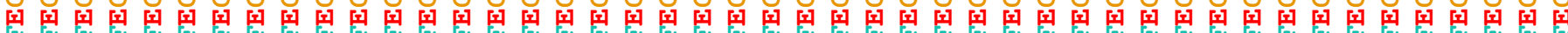

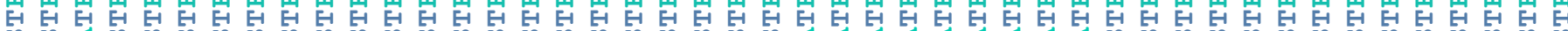

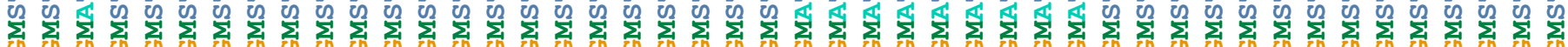

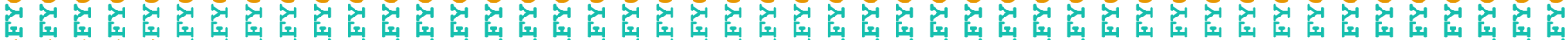

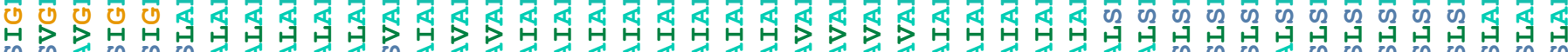
O2

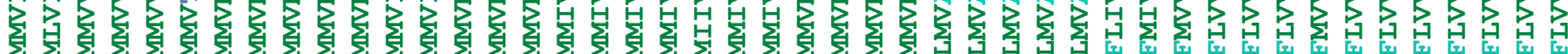

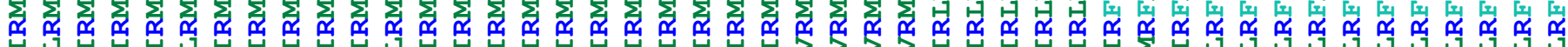
S5 5 S

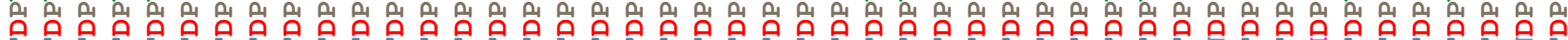

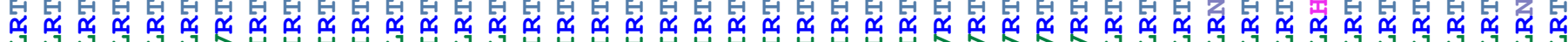

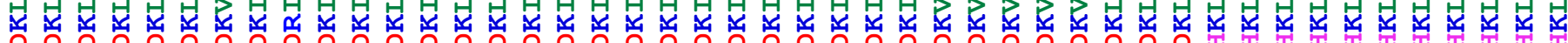

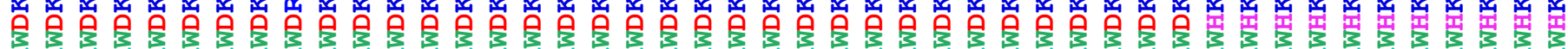

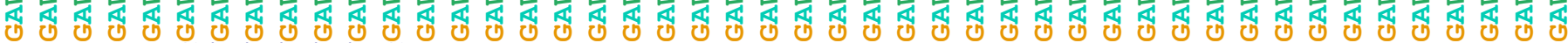

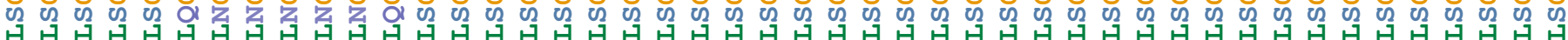

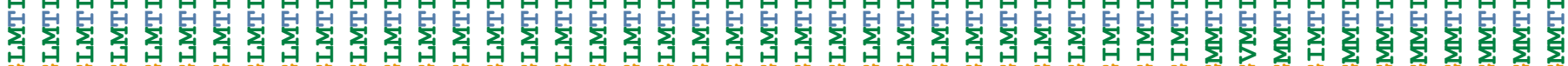

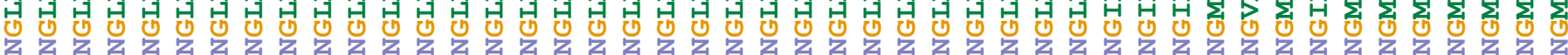

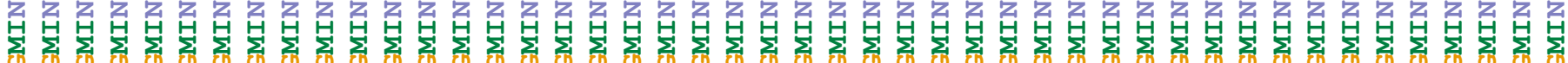

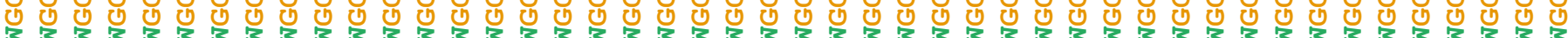

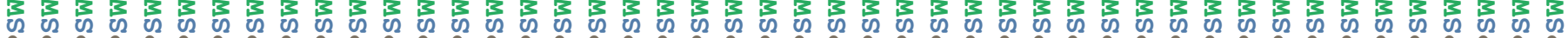

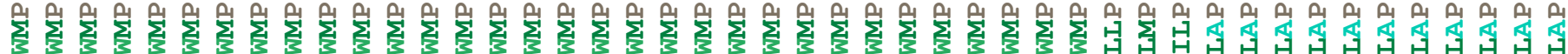

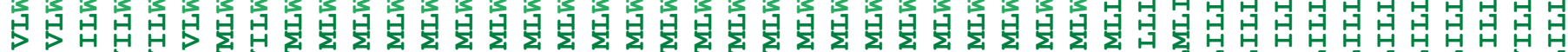

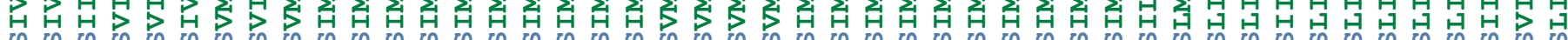

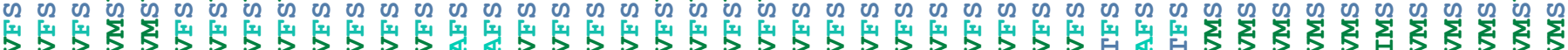

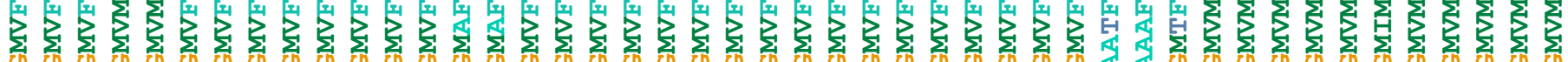

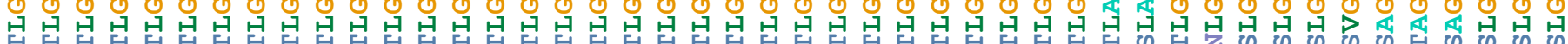

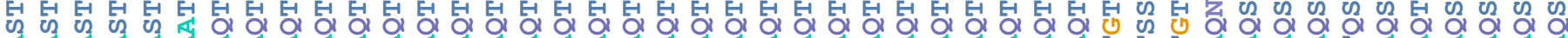

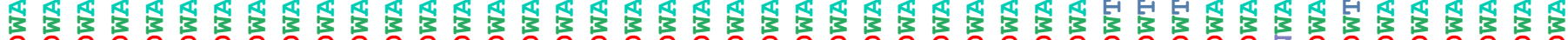

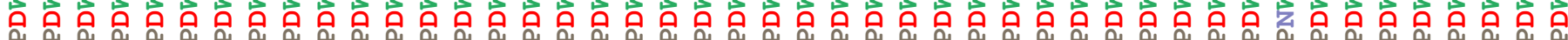

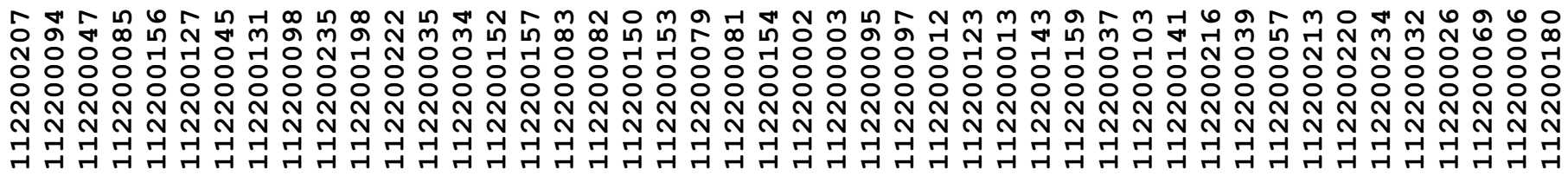




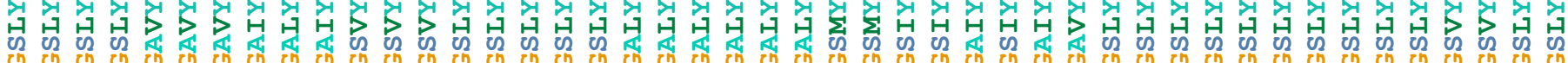

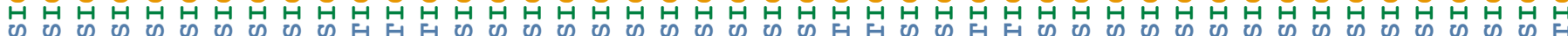

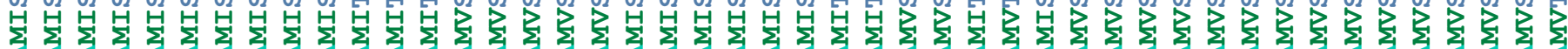

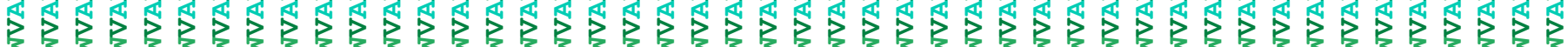

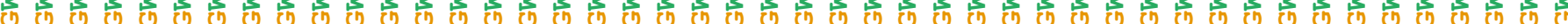

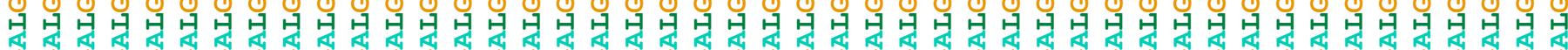

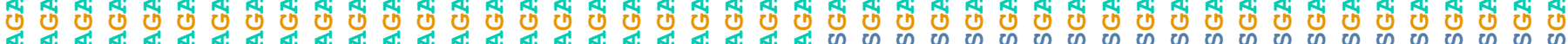

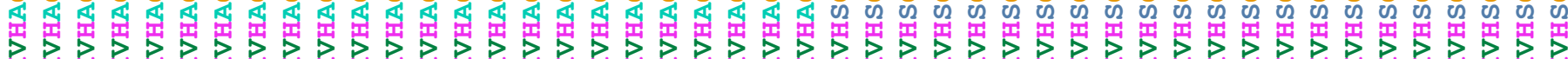

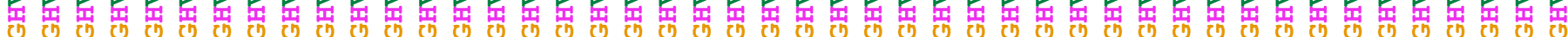

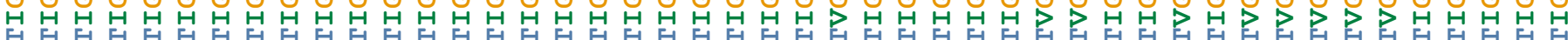

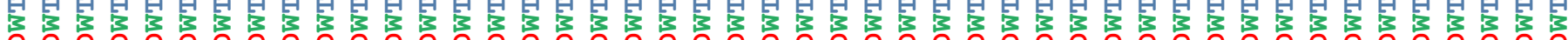

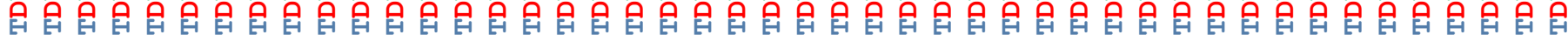

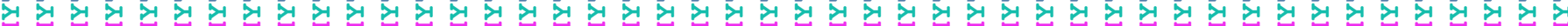

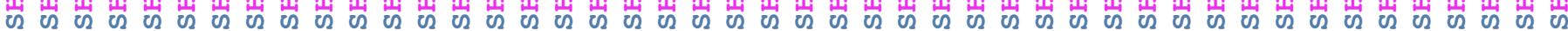

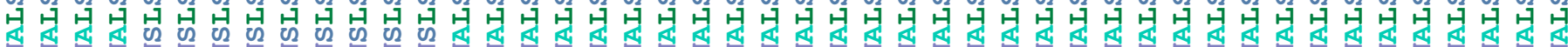

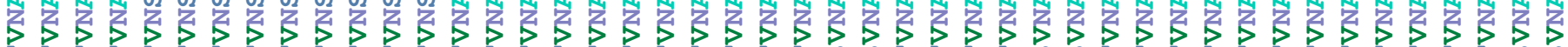

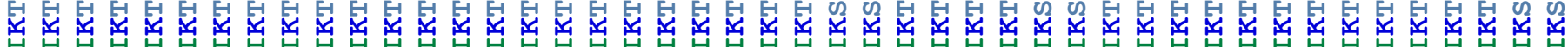

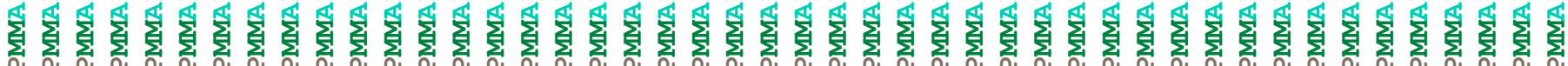

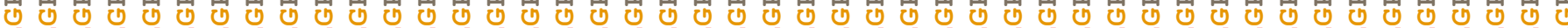

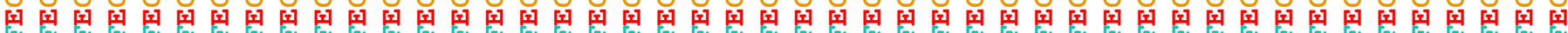

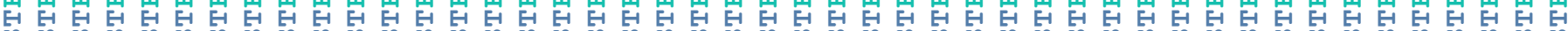

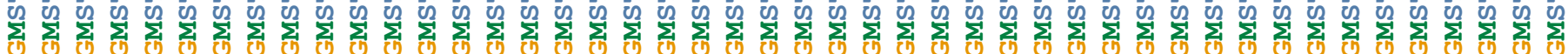

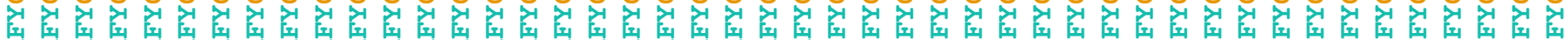

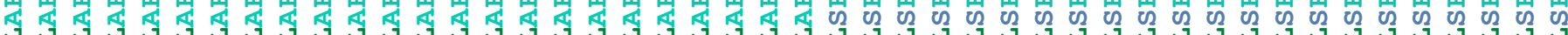

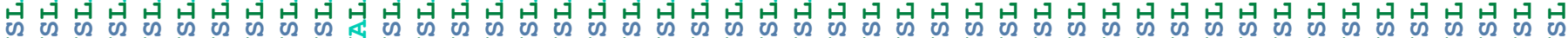

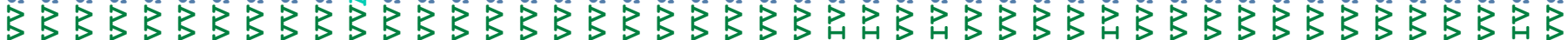

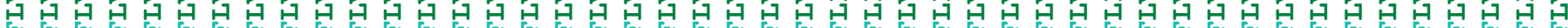

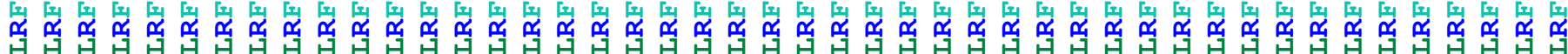

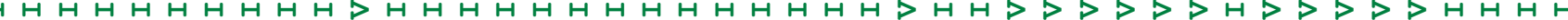

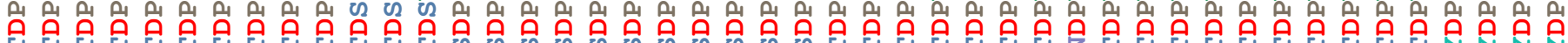

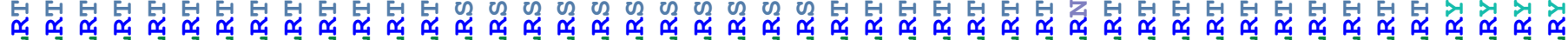

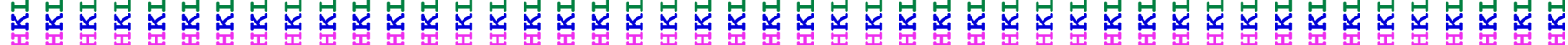

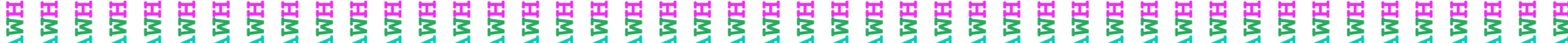

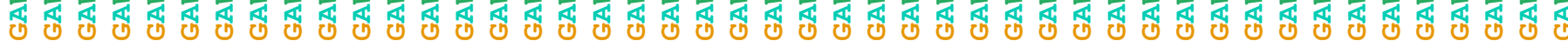

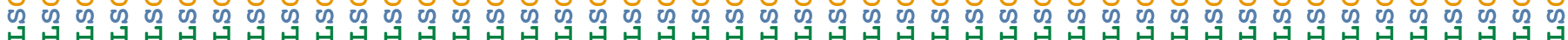

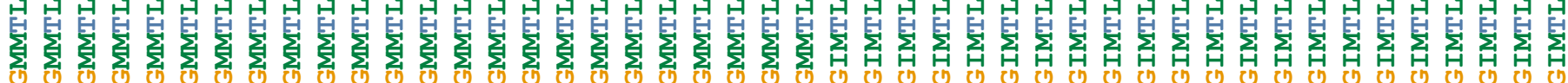

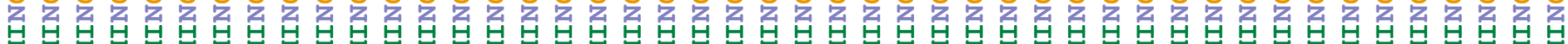

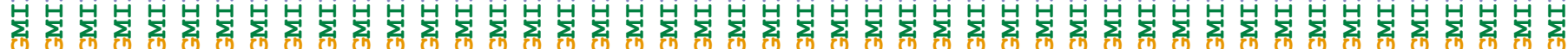

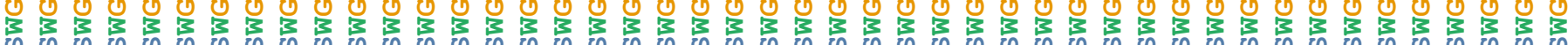

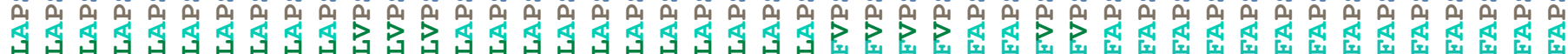

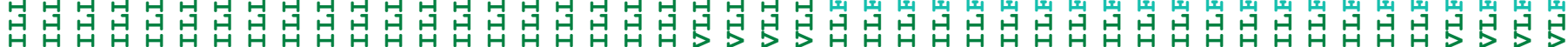

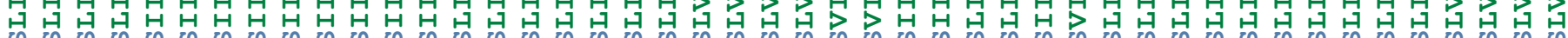

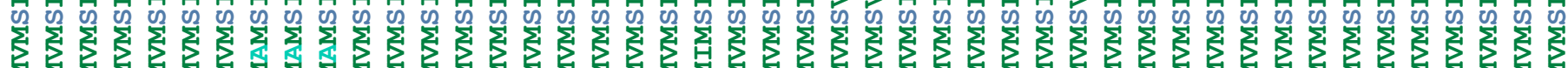

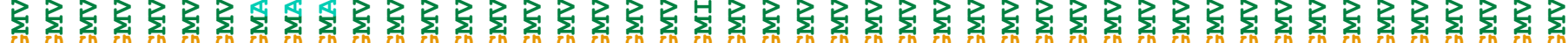

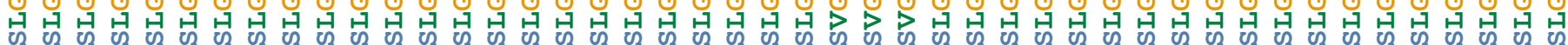

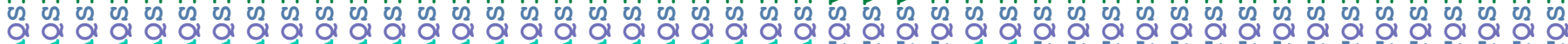

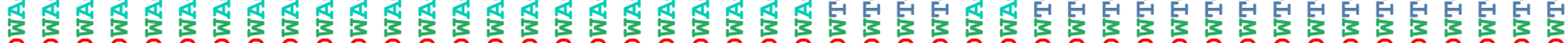

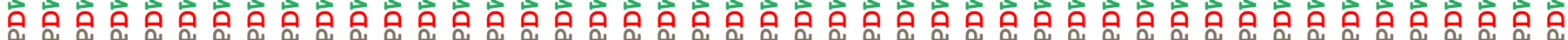

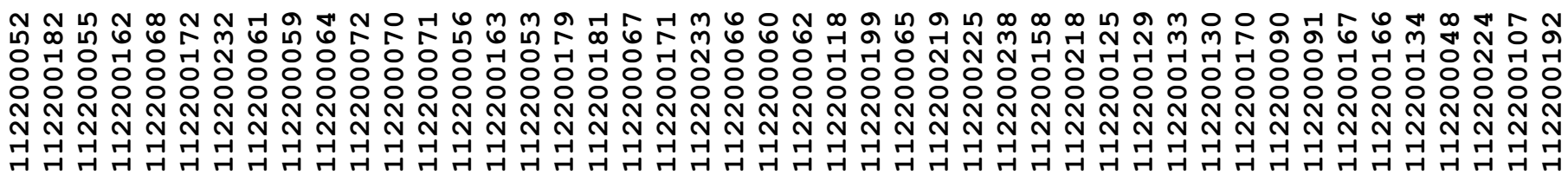




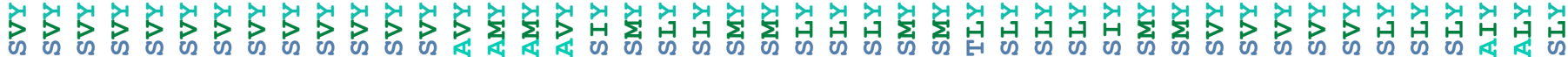

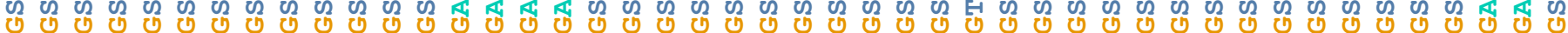

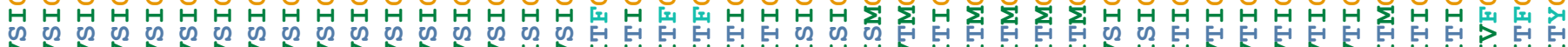

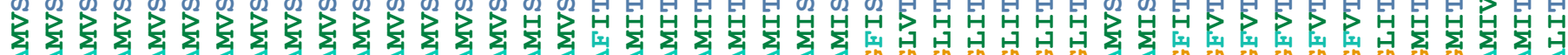
(5)

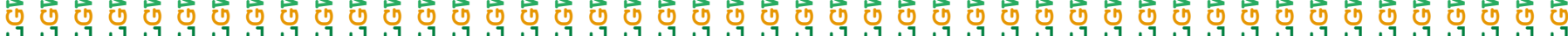

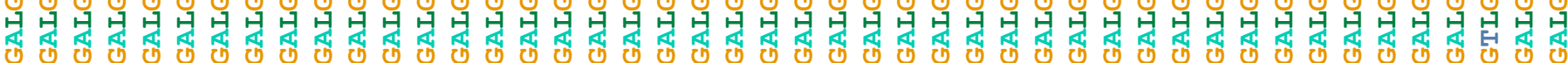

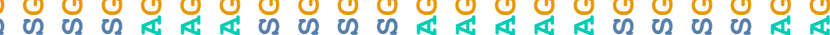

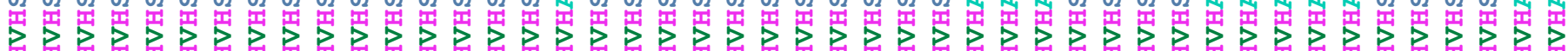

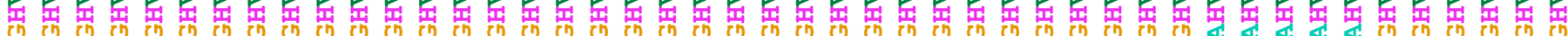

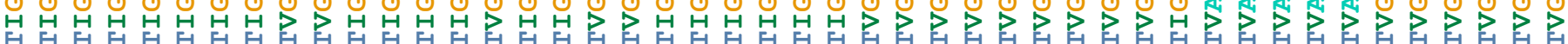

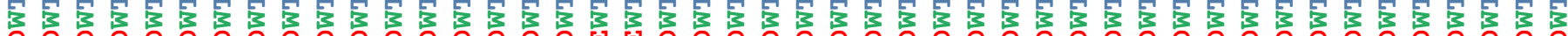

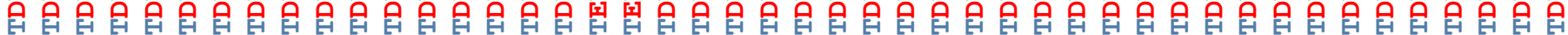

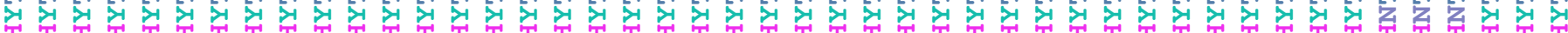

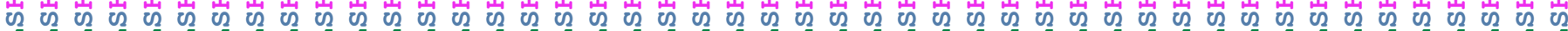

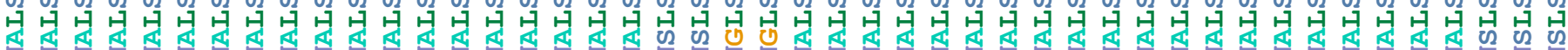

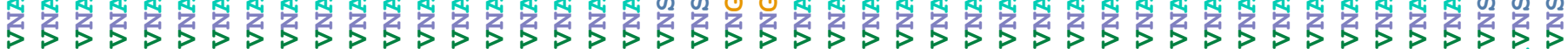

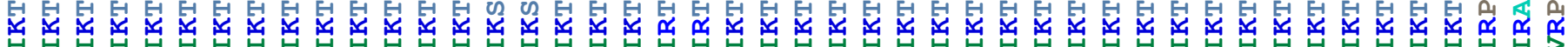

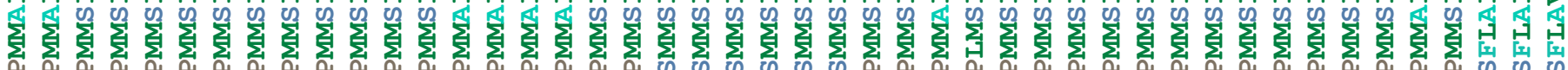

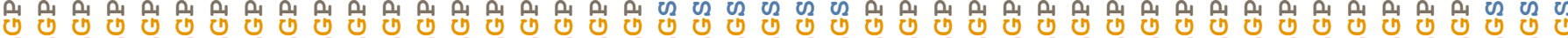

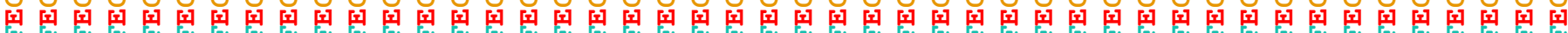

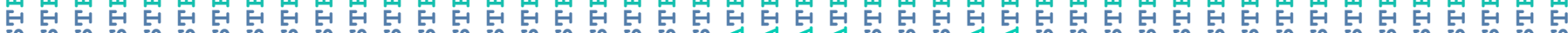

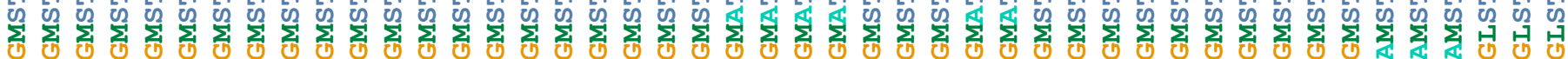

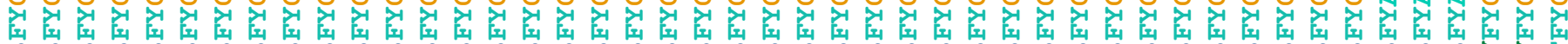
๘ू

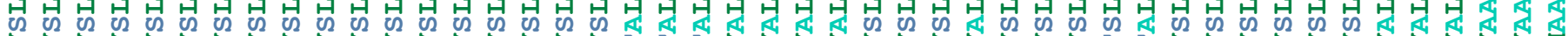

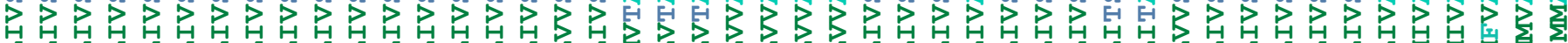

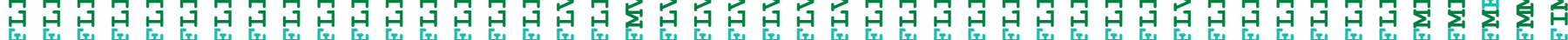

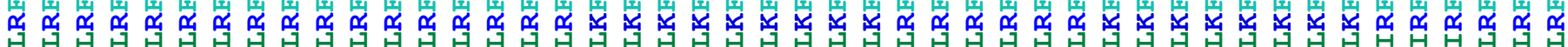

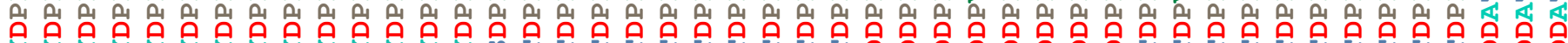

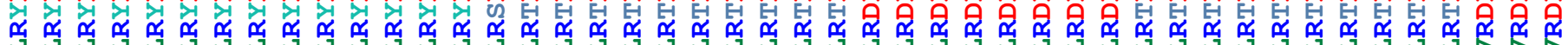

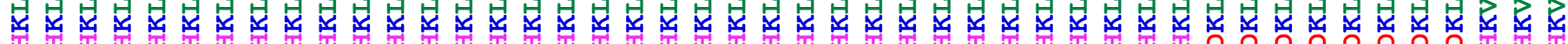

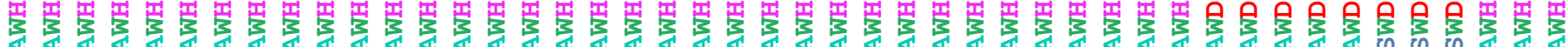

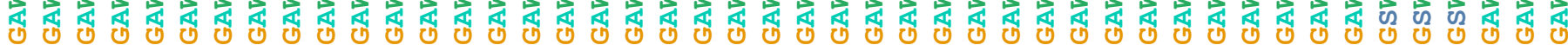
ఝ్

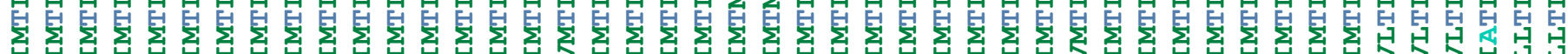

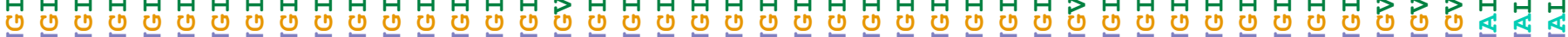

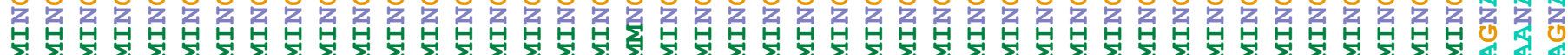
绍

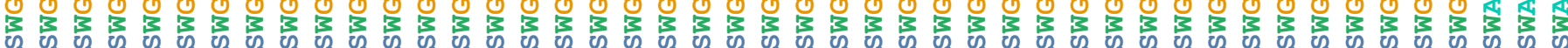

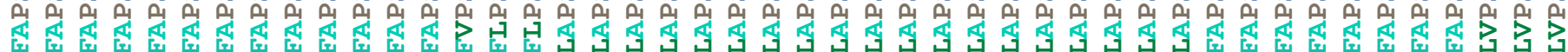

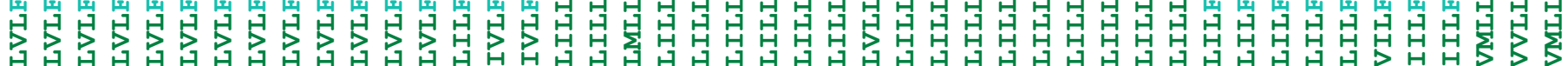

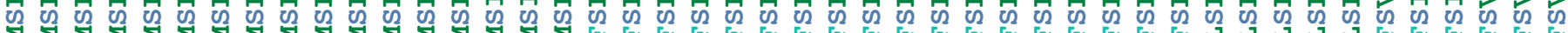

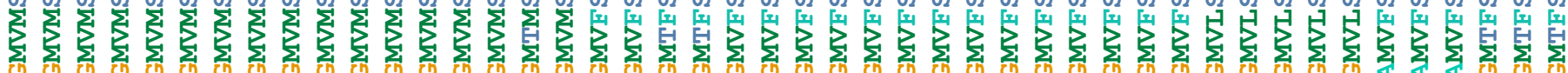

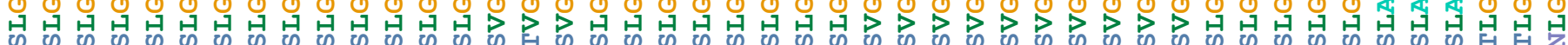
O

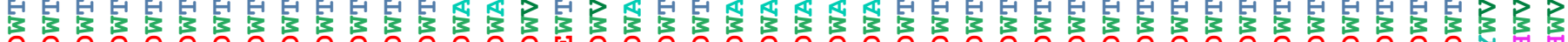

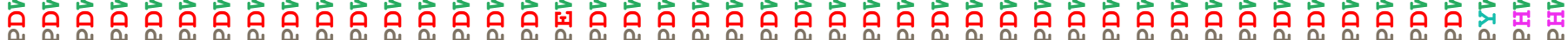

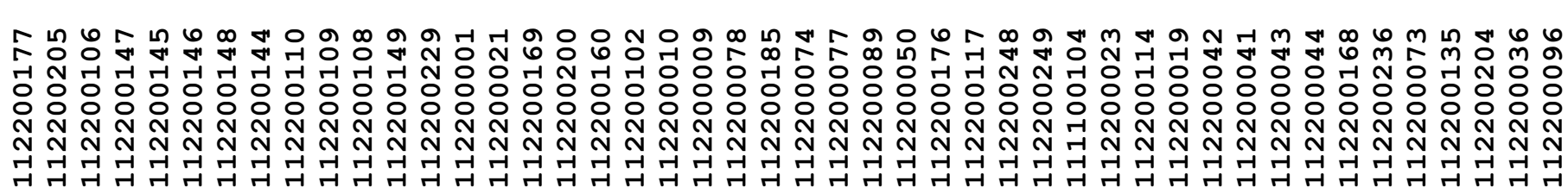




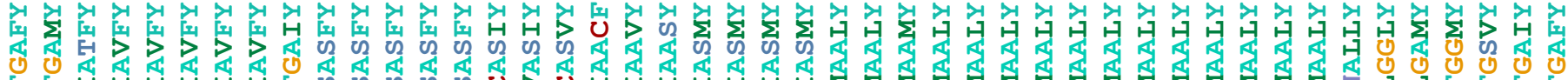

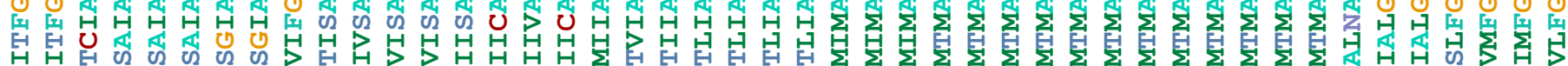

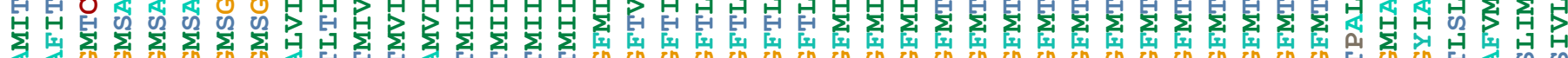

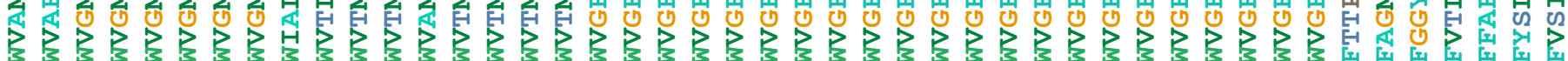

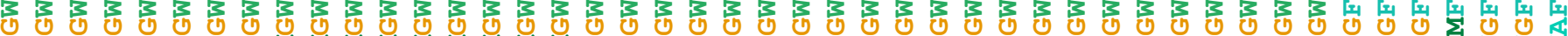

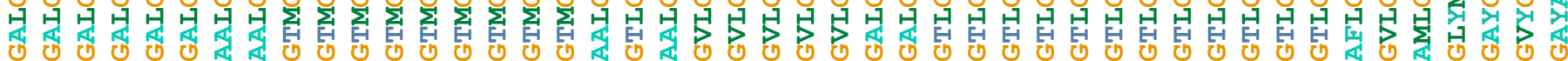

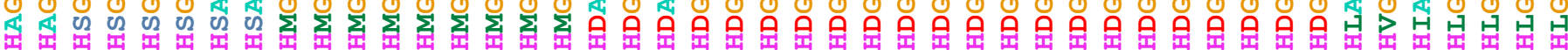

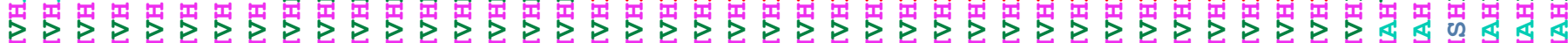

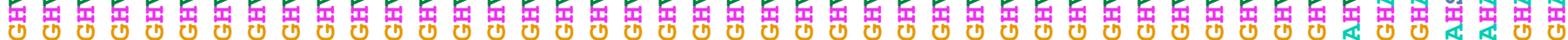

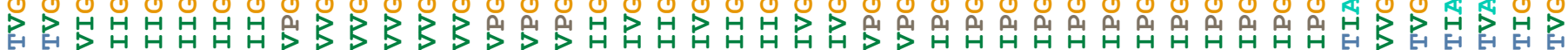

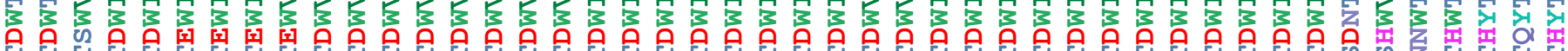
列

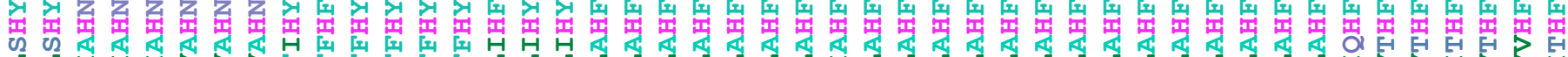

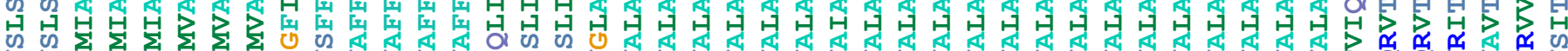

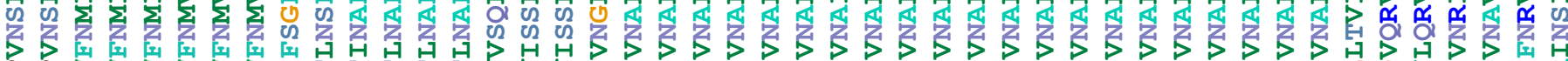

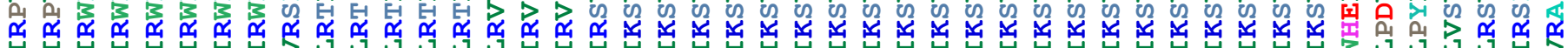

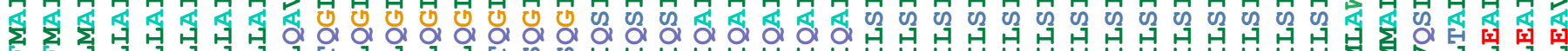

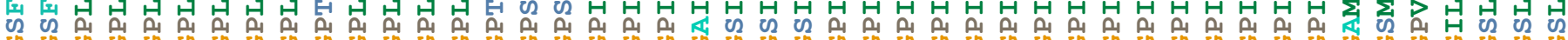

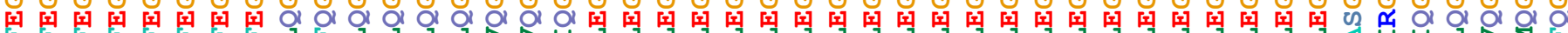

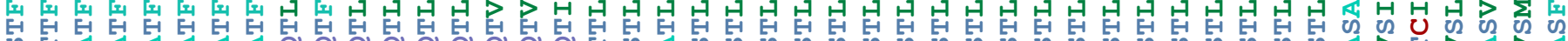

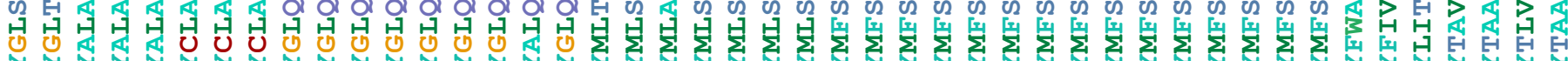
国

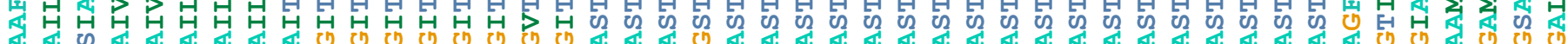

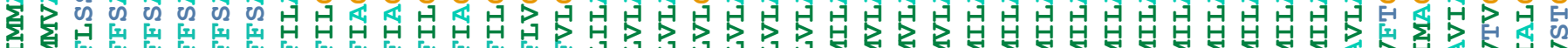

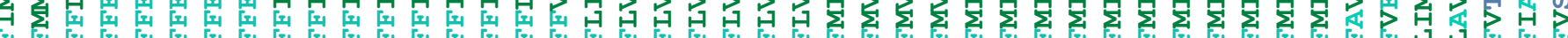

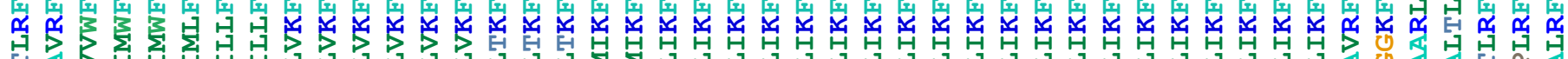

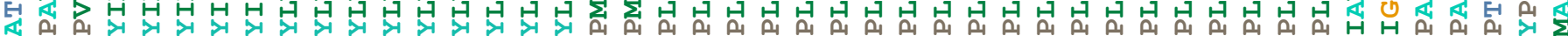

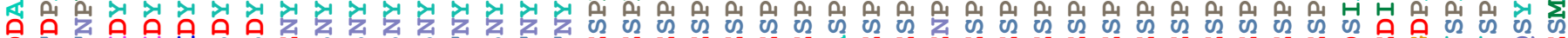

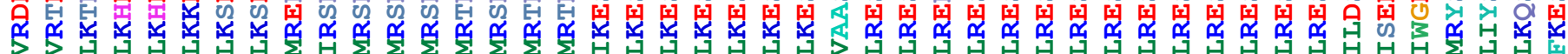

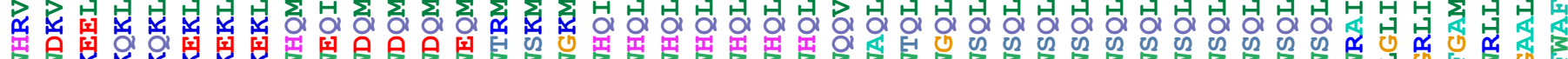

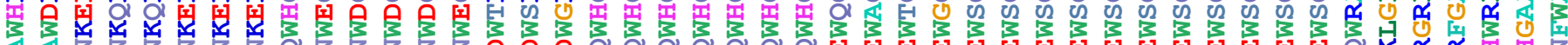
质

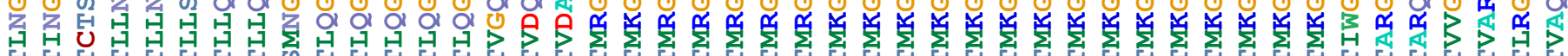

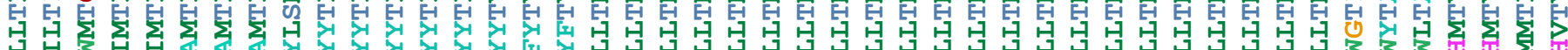

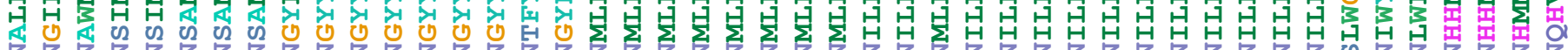

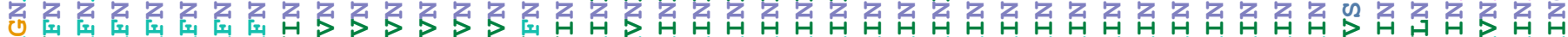

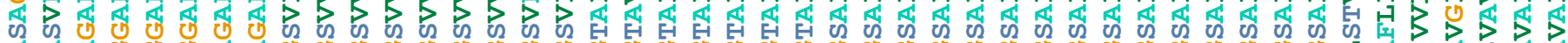

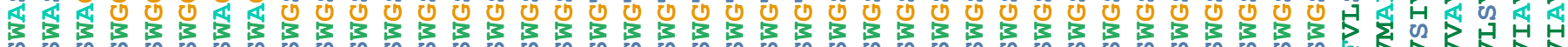

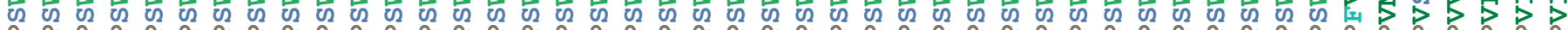

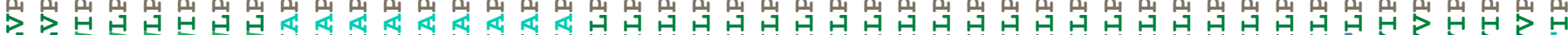

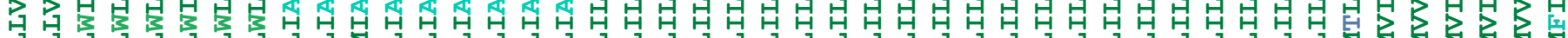

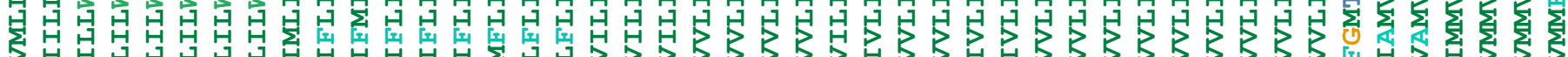

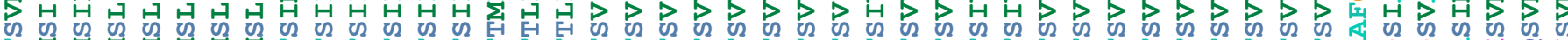

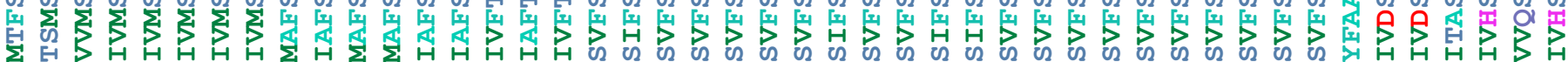

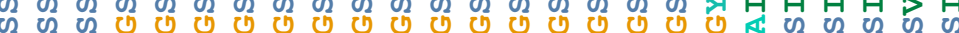

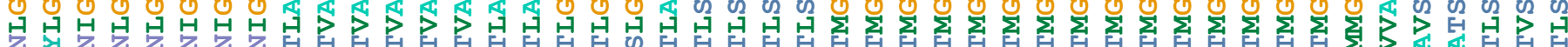

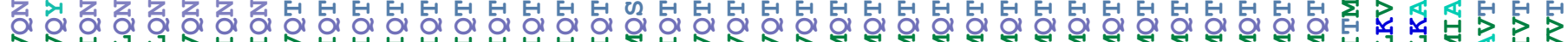
在

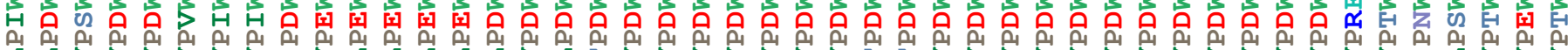

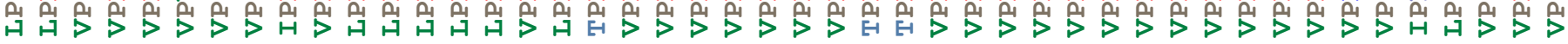

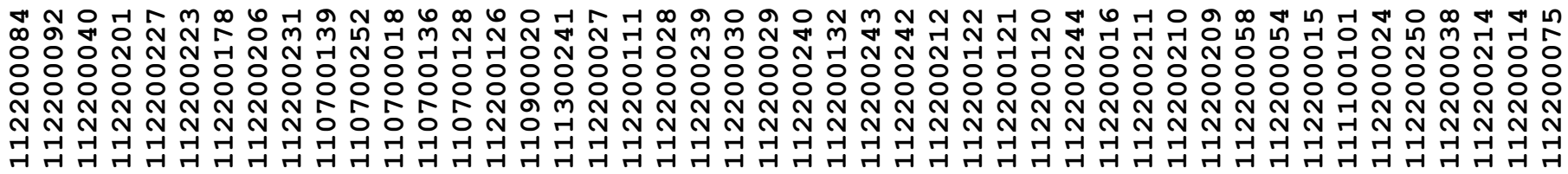


P्म

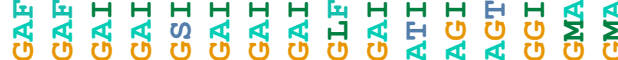

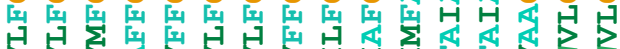

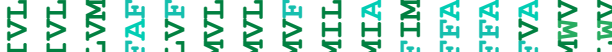

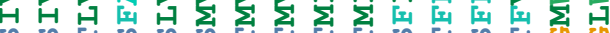
थ

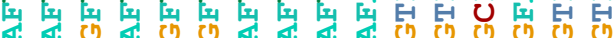

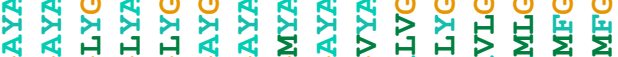

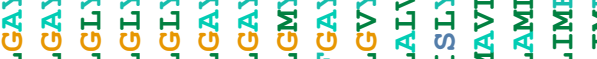

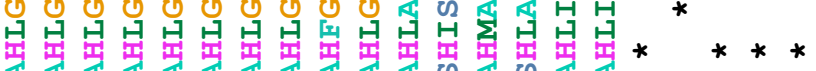

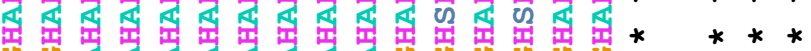

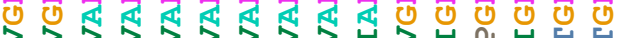

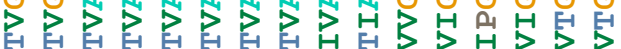

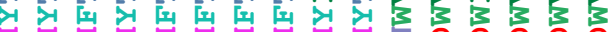
昰

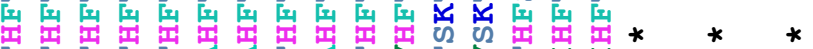
E E

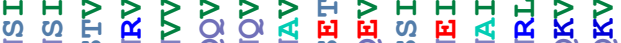

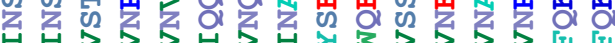

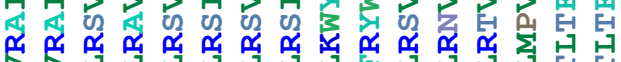

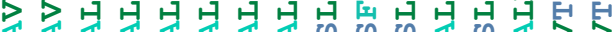
国 闵

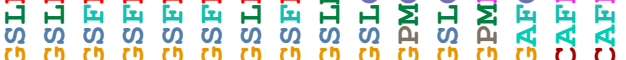

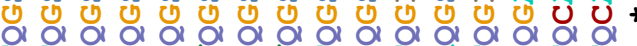

利 作

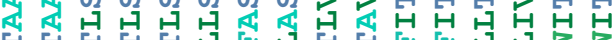

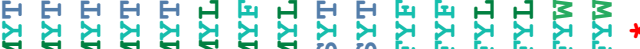

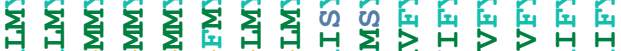

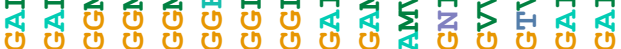

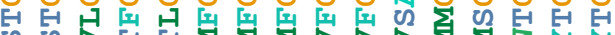

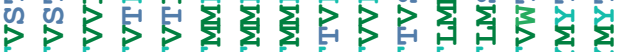

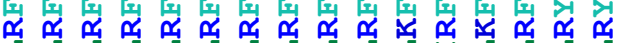

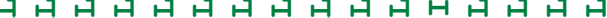

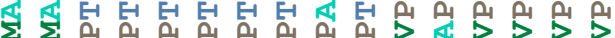
次次次次次次

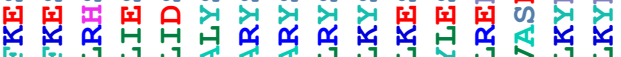

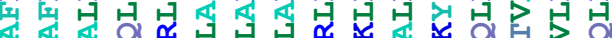

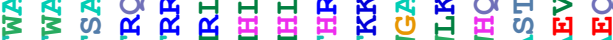

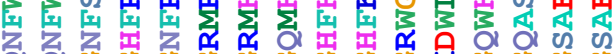

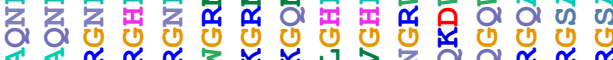

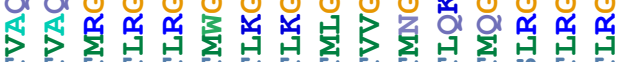

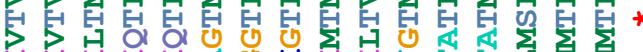

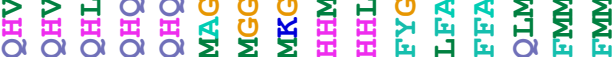

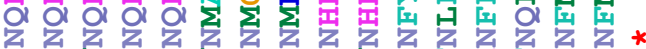

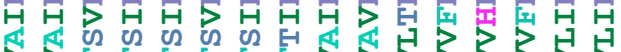
$\gg \gg$

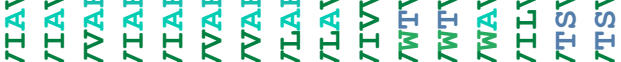

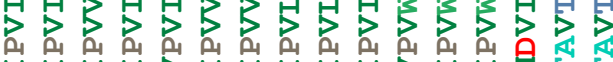
$\mathrm{HH} H \gg \mathrm{H} H \mathrm{H} \longrightarrow \mathrm{H} \mathrm{H}_{\mathrm{C}} \mathrm{H}$

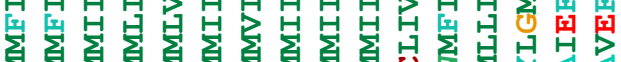

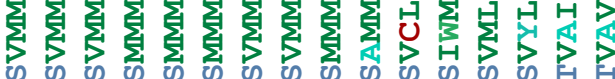
要江

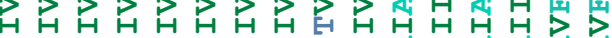

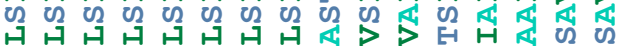

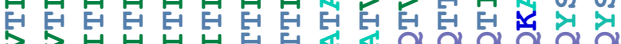

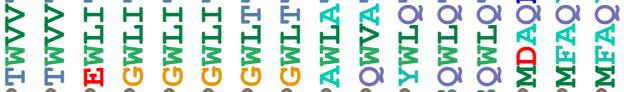

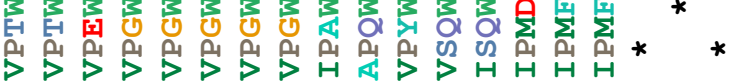

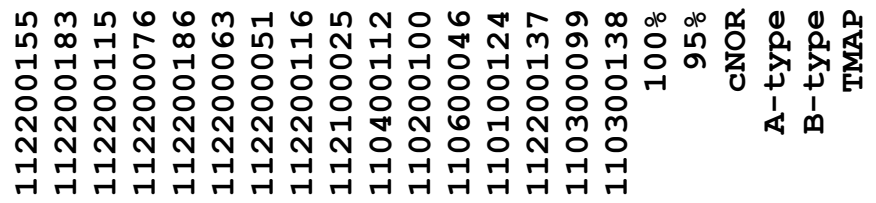

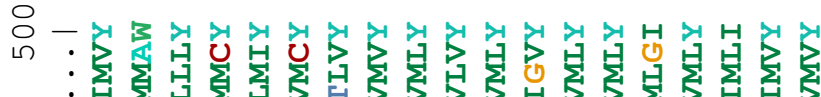
.

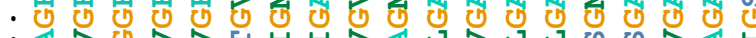

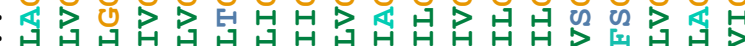
0.

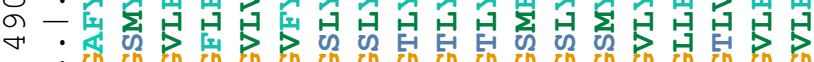

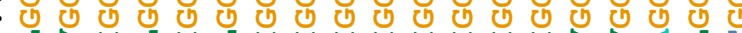

-

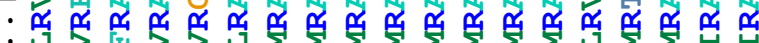

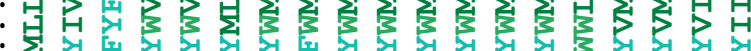
$0 . \sum^{3} \underbrace{}_{1}$

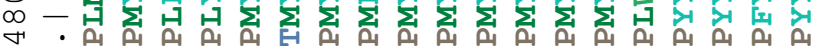

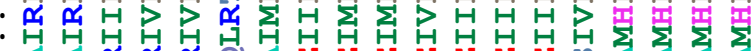

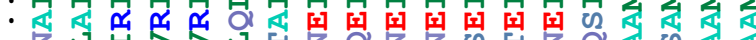

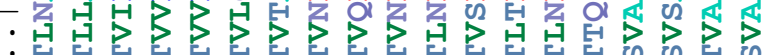

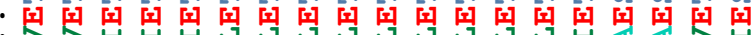

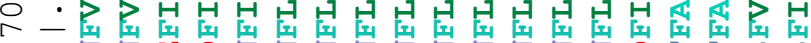

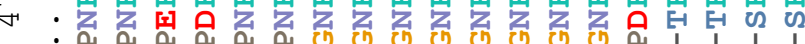
: ગ્રે ગ્ર

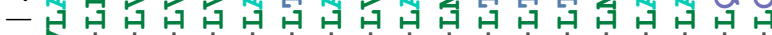
-

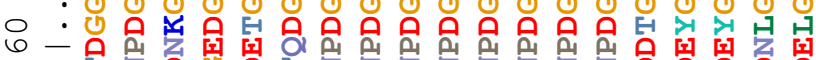

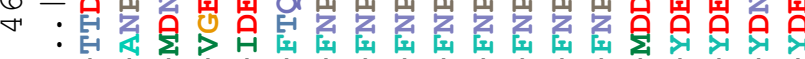
- I l l l l l l l l l l l l l l l l l l l l

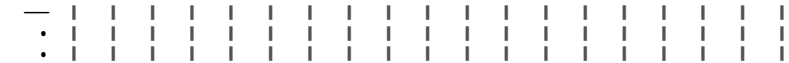

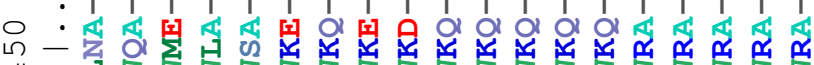

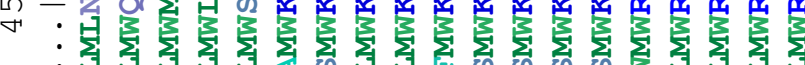

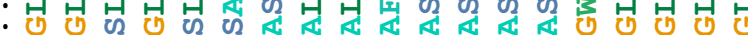

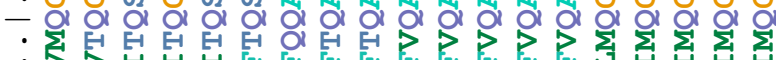
$0:$ थ

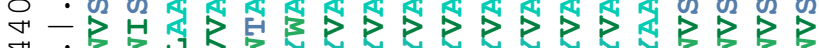

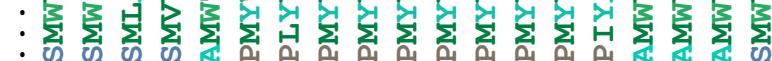

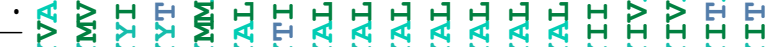
- कि

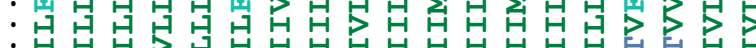

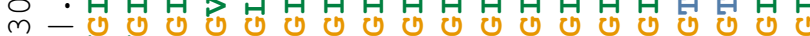
$\checkmark: D P H$

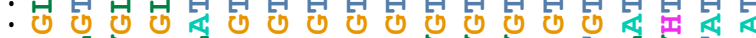

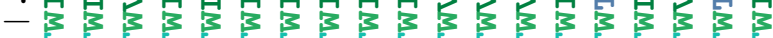

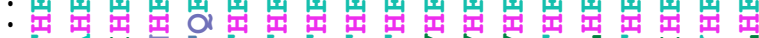

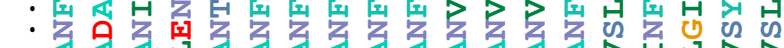

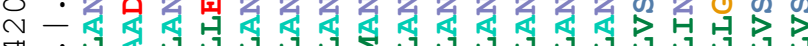

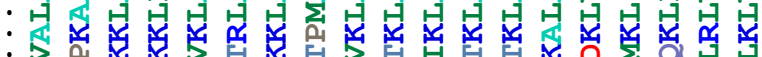

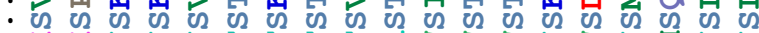

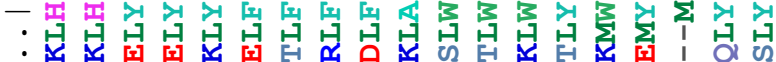

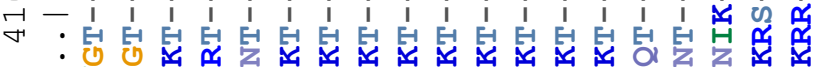

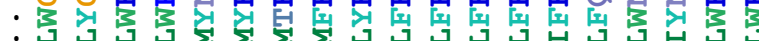

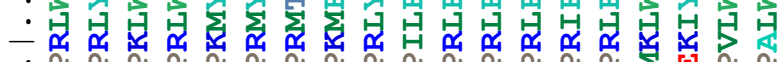

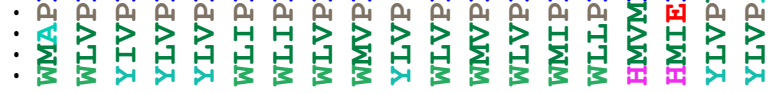

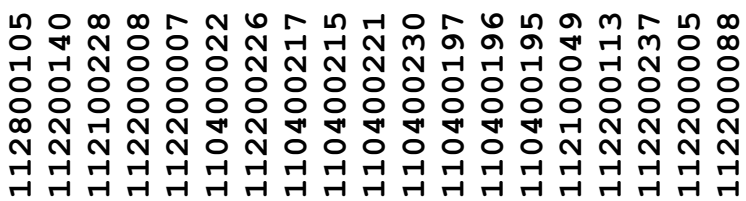




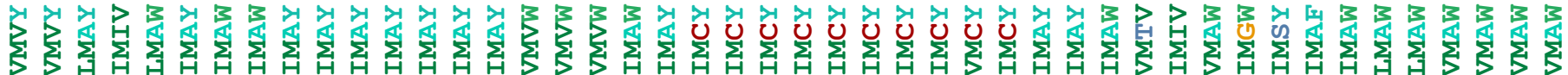

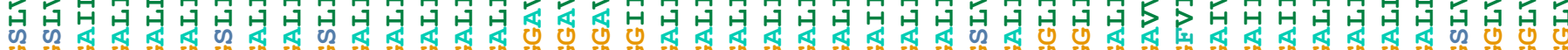

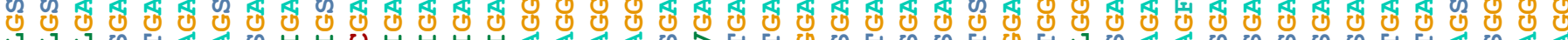

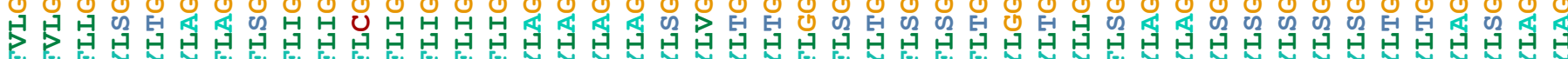

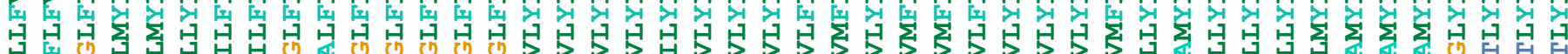
更 等

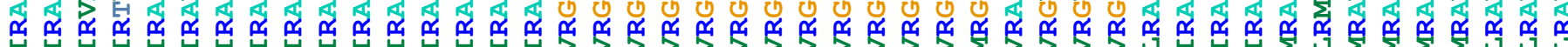

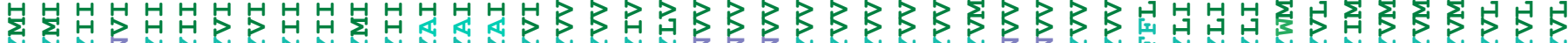

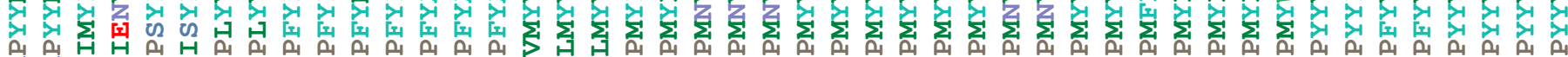

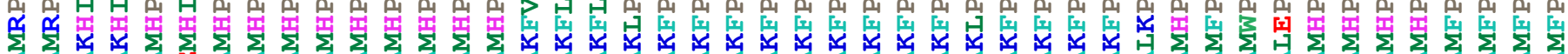

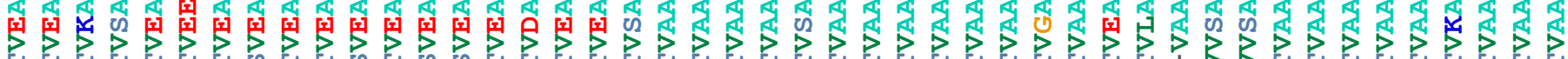

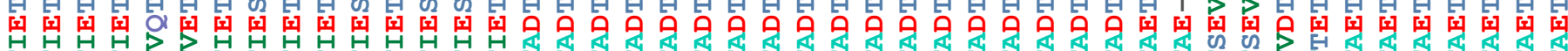

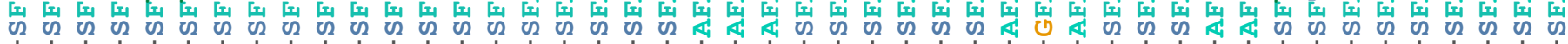

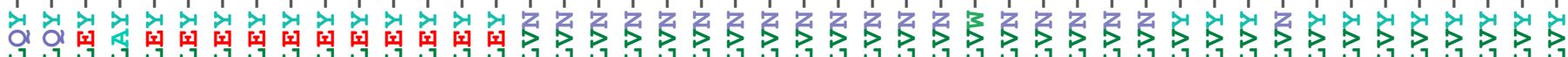

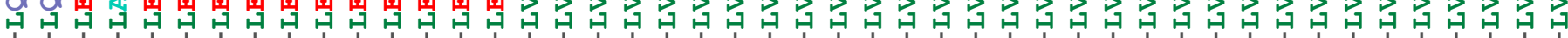

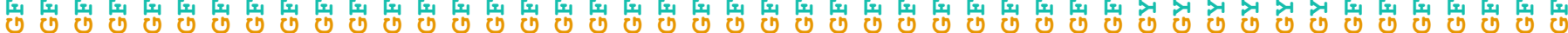

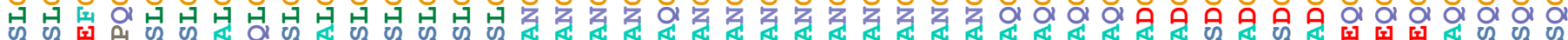

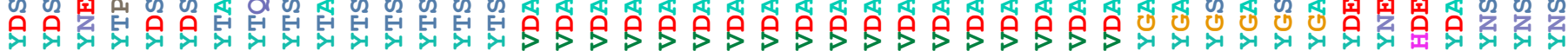

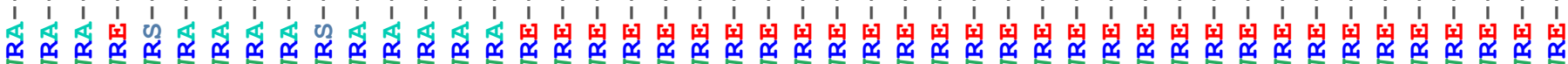

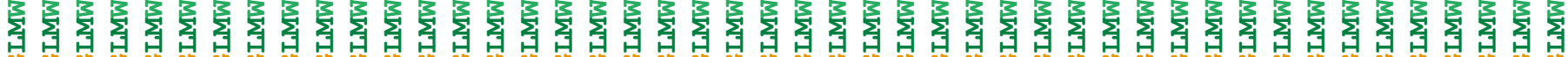

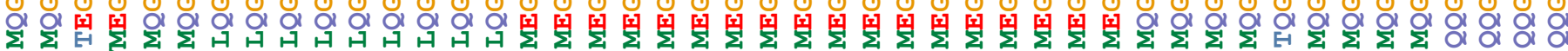

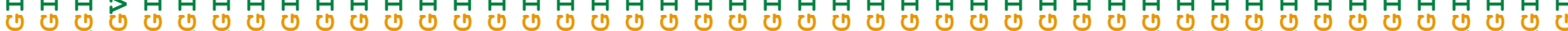
以

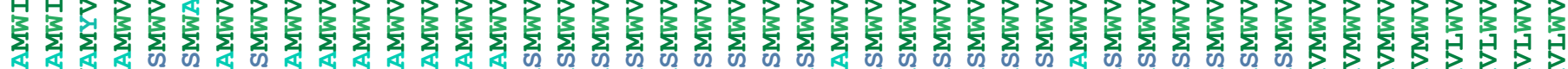

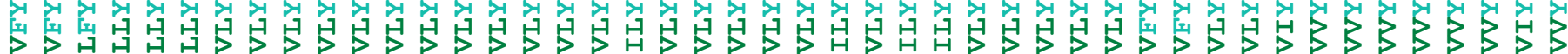

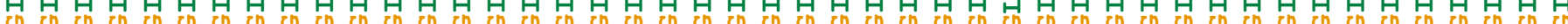

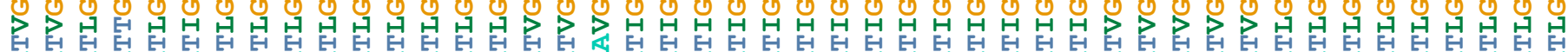

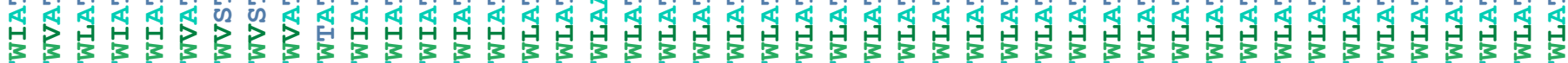

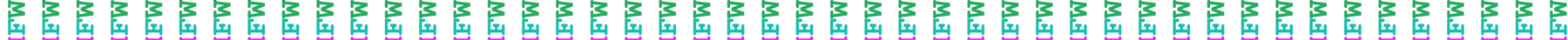

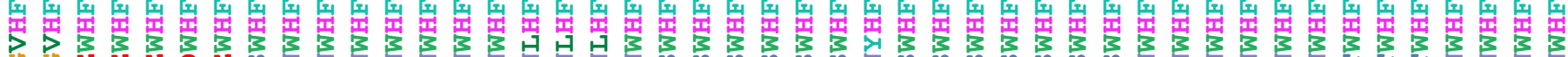

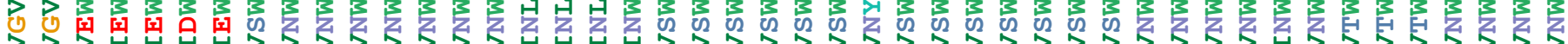

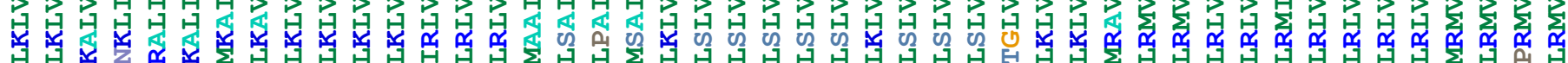

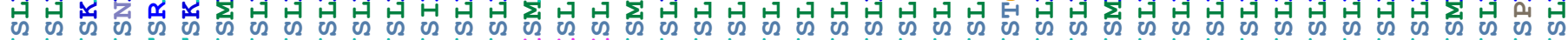

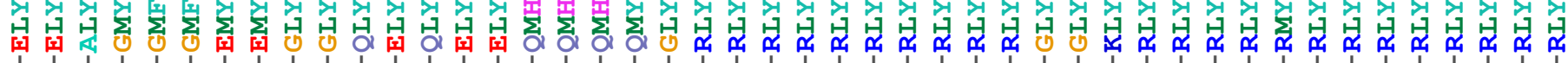

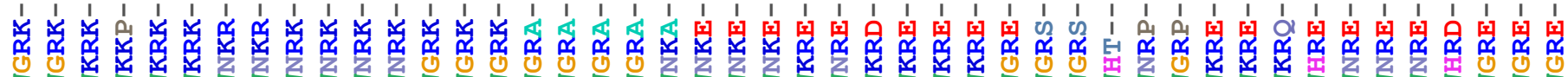

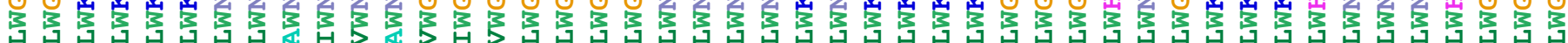

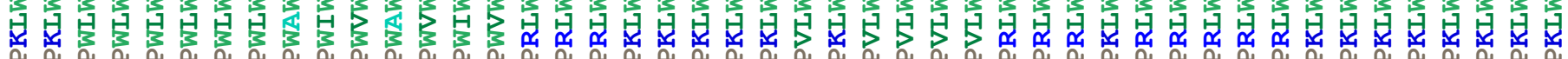

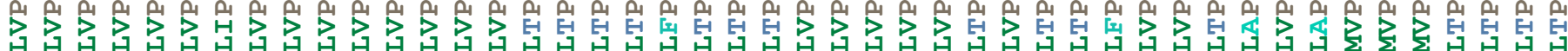

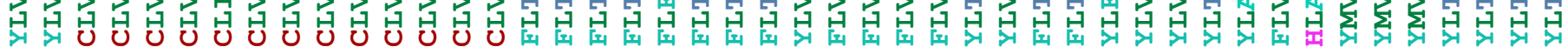

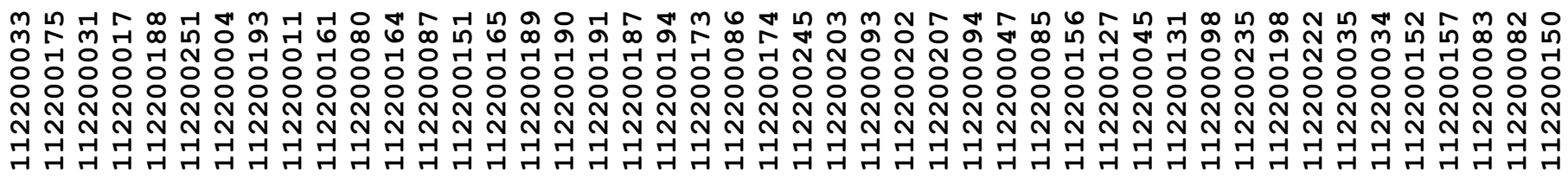




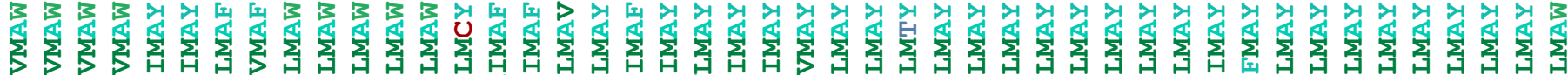

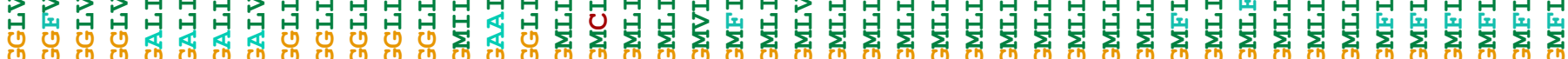

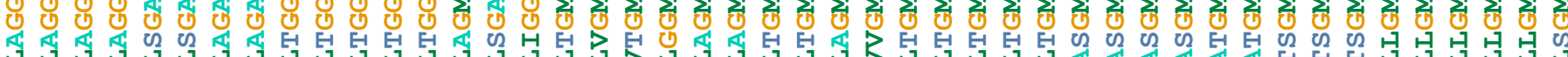

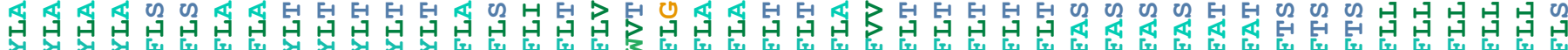

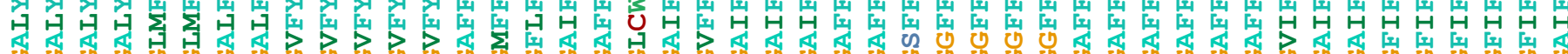

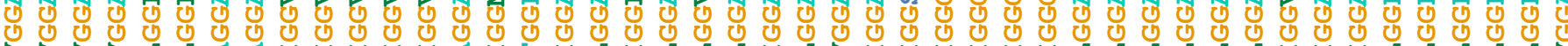

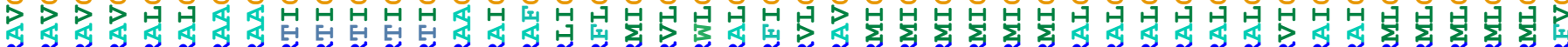

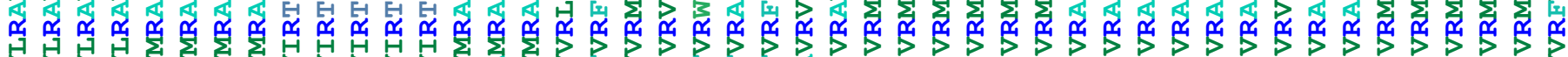

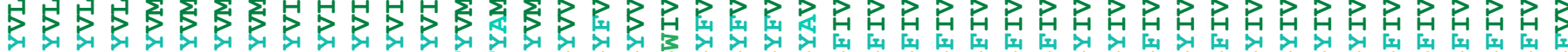

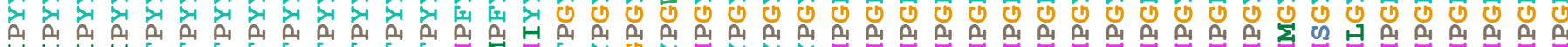

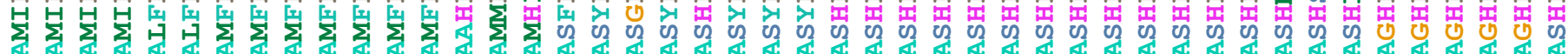

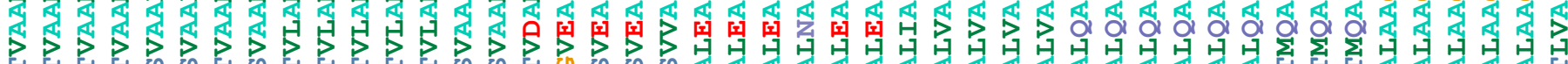

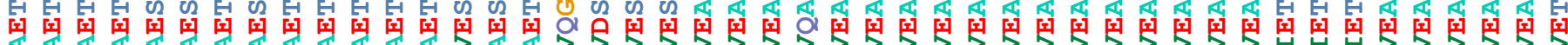

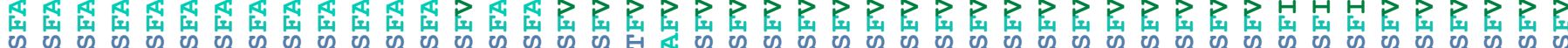

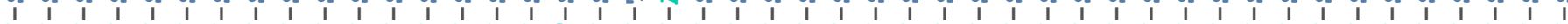

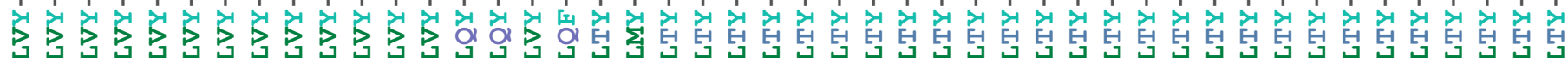

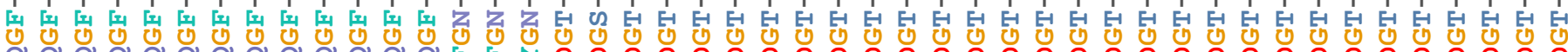

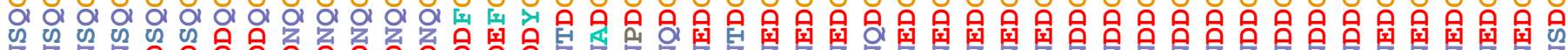

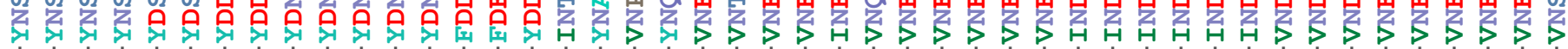

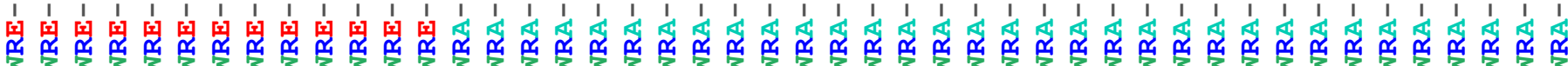

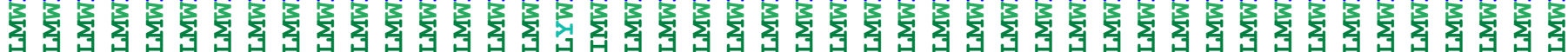

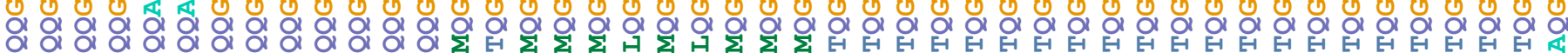

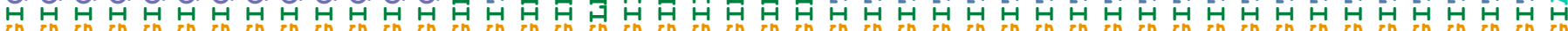

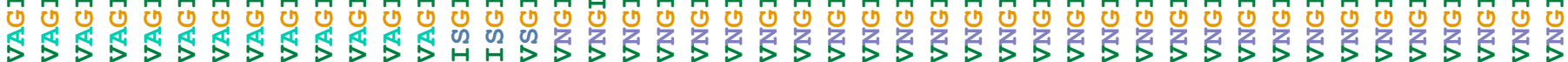

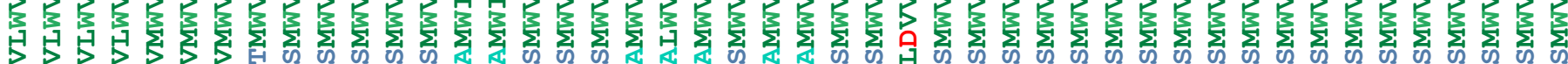
कथल कथ का

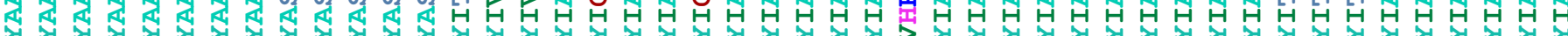

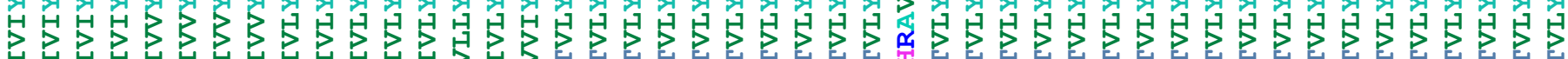

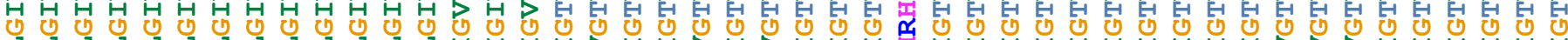

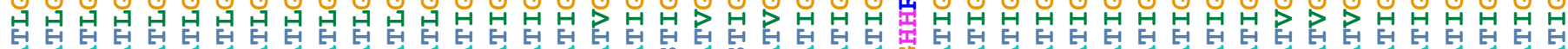

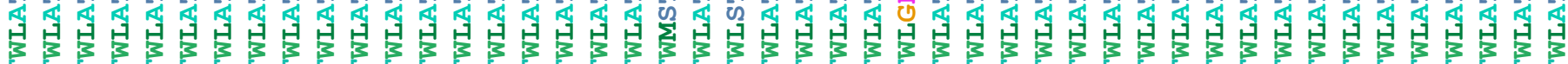

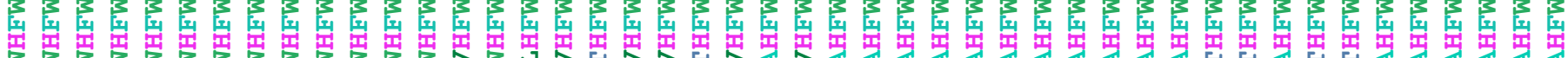

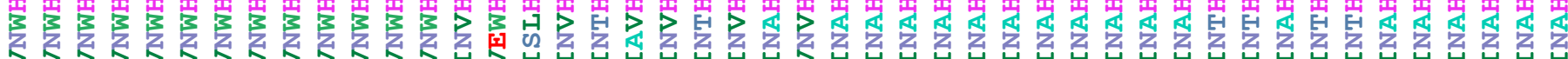

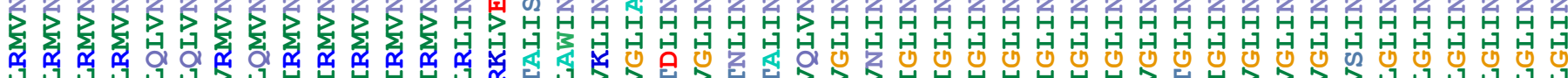

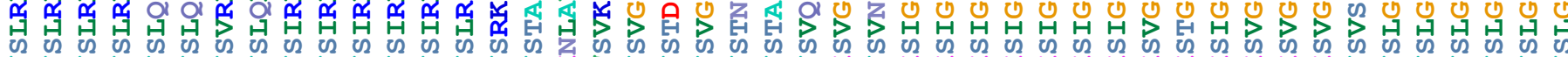

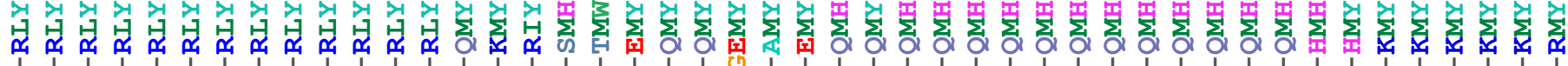

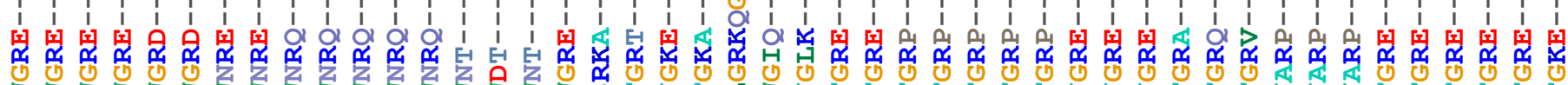

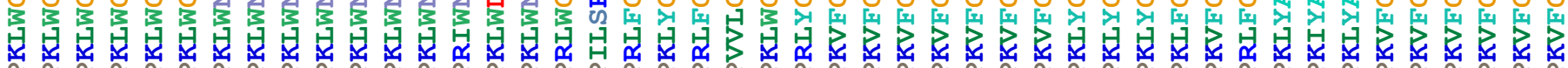

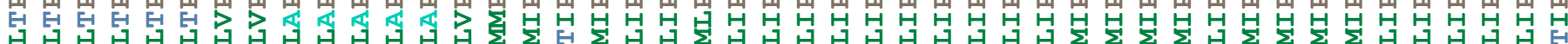

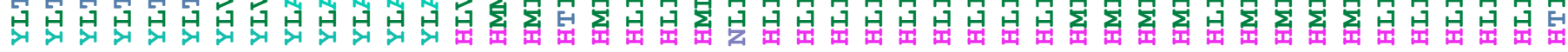

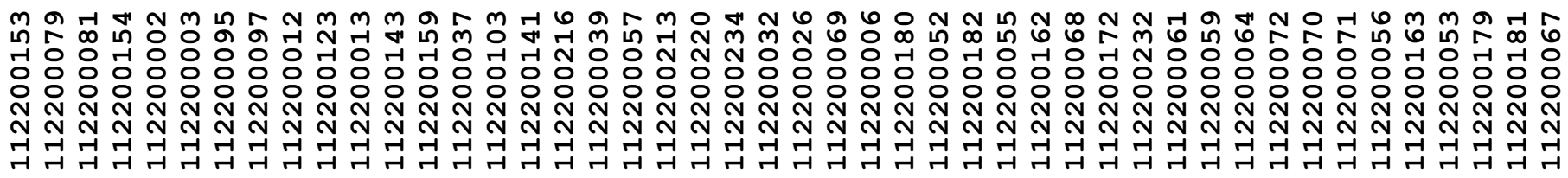




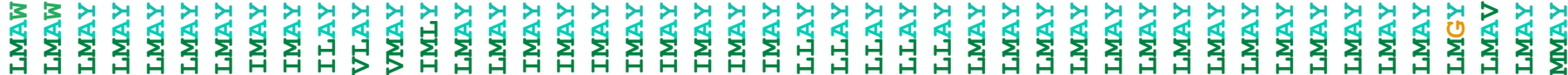

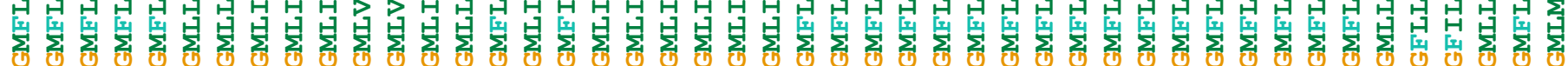

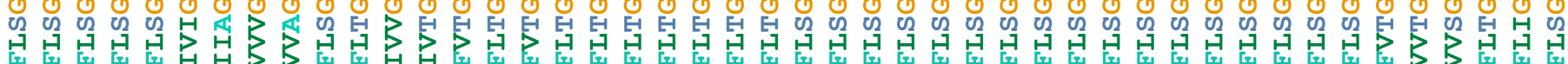

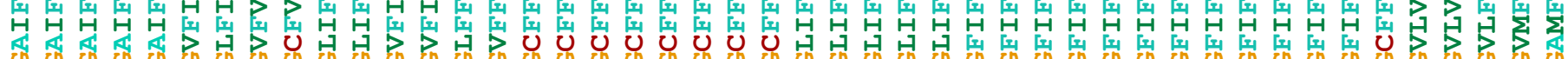

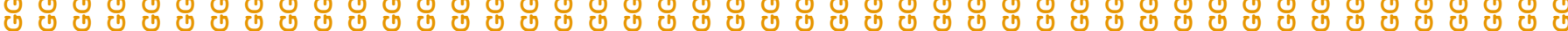

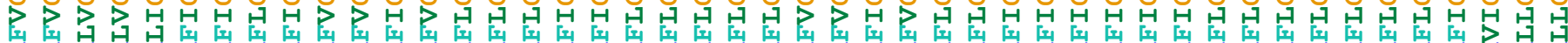

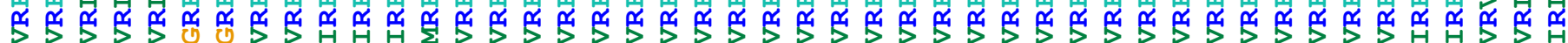

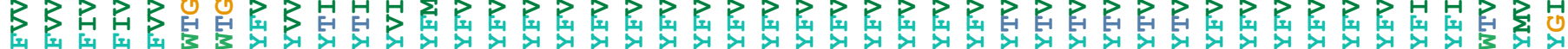

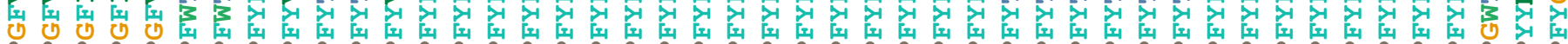

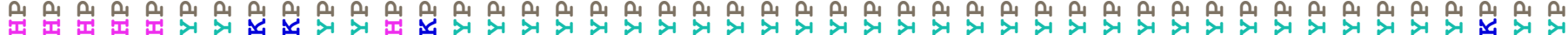

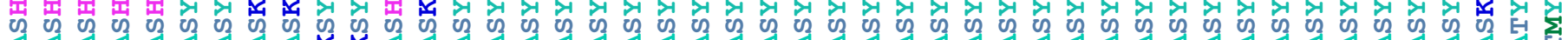

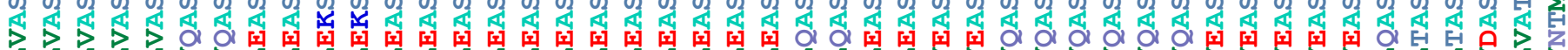

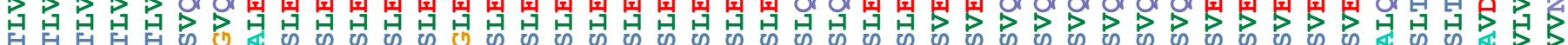

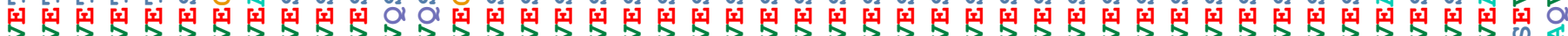

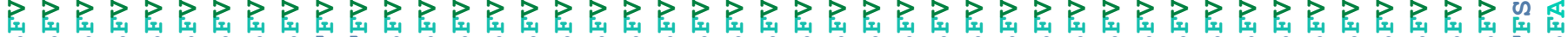

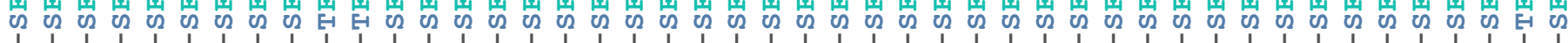

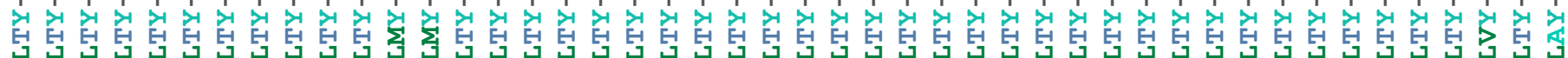

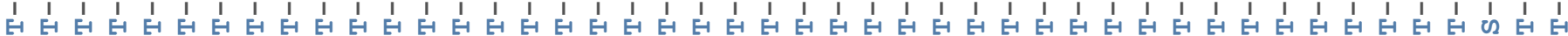

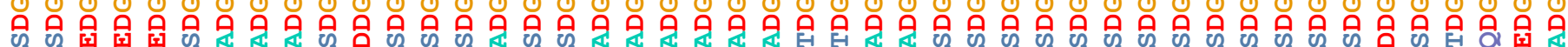

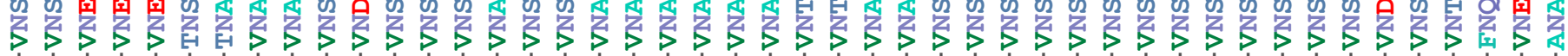

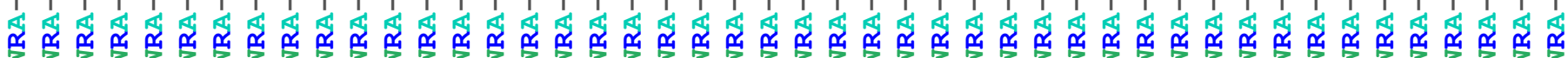

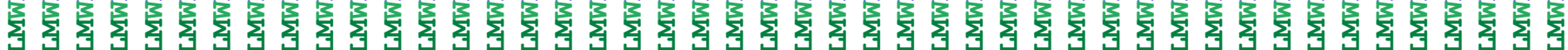

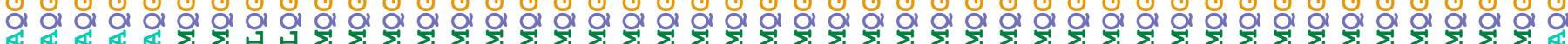

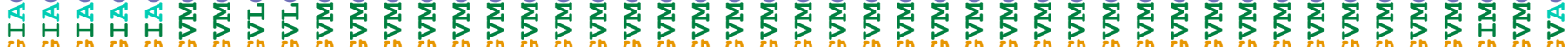

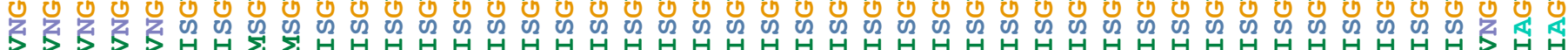

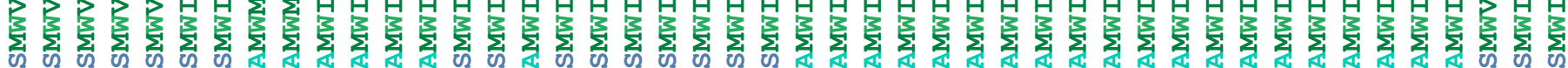

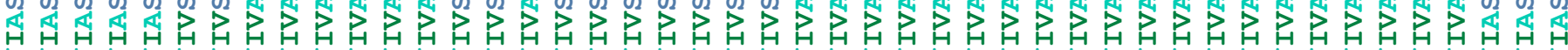

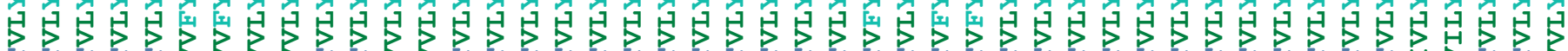

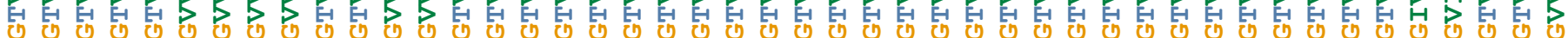

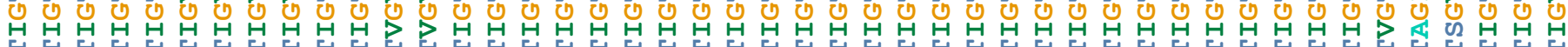
Het

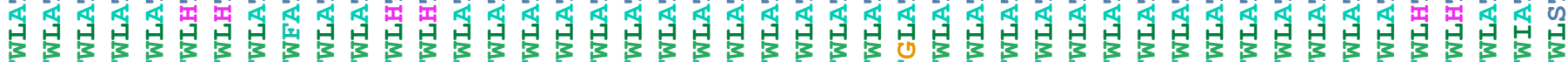

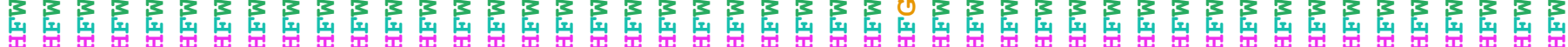

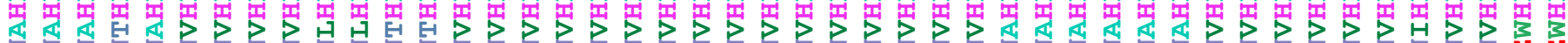

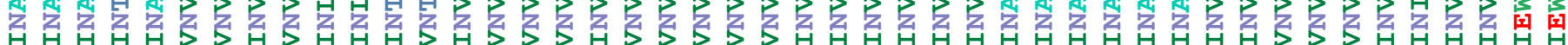

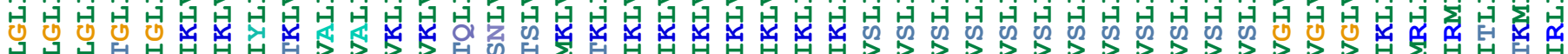

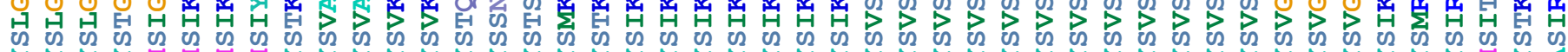

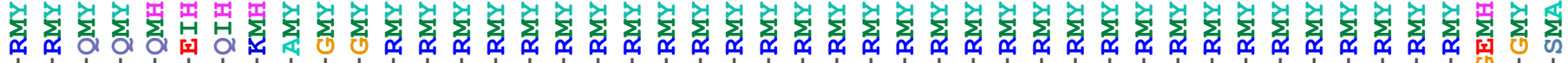

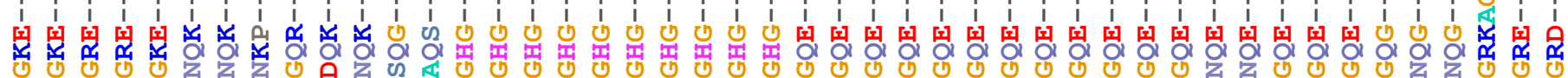

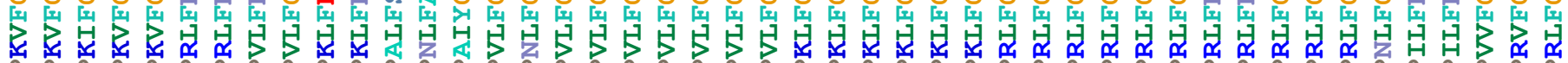

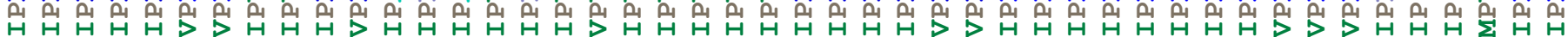

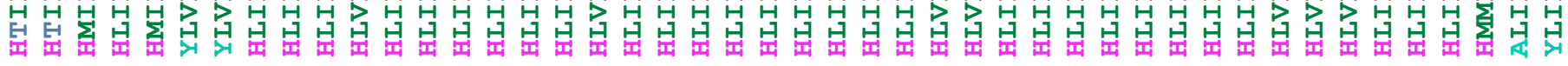

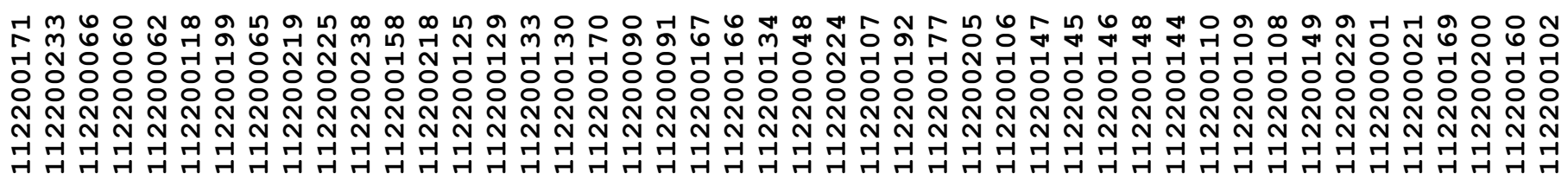




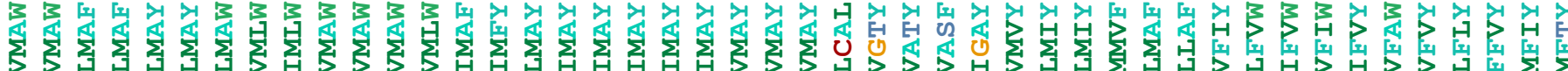

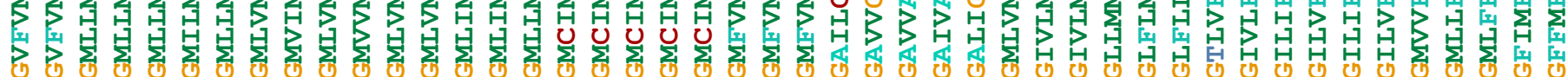
作

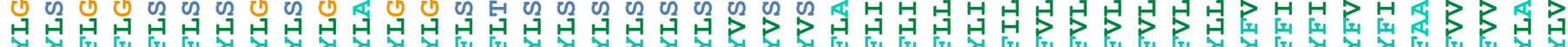

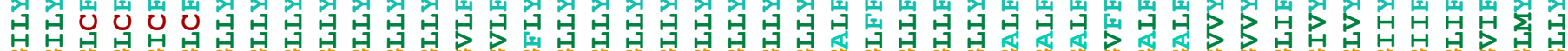
作

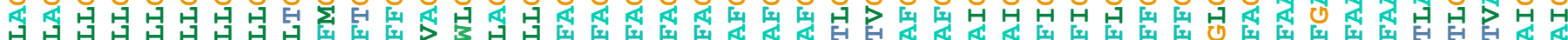

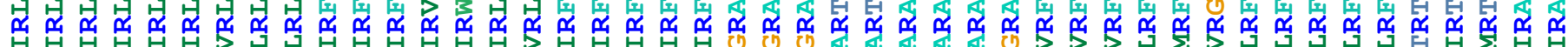

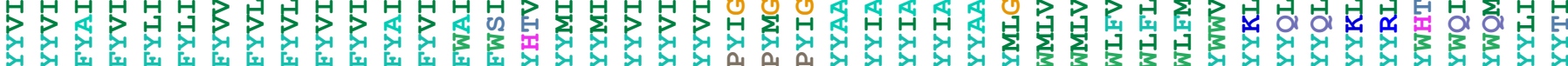

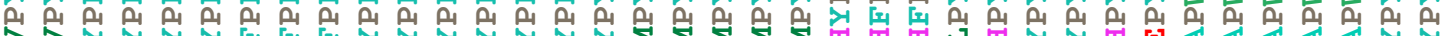

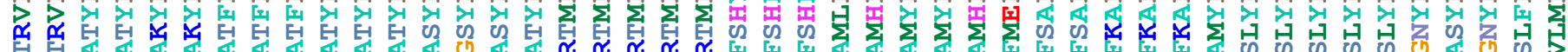

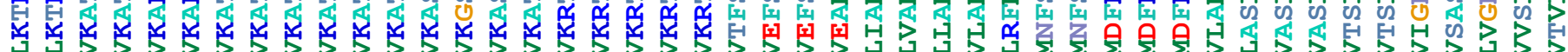

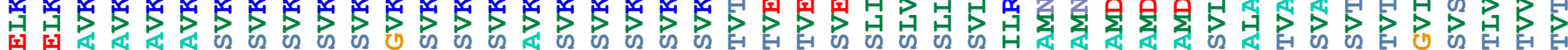

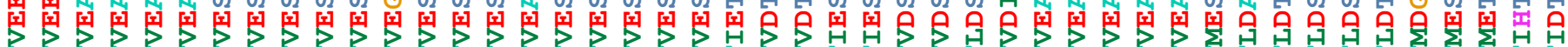

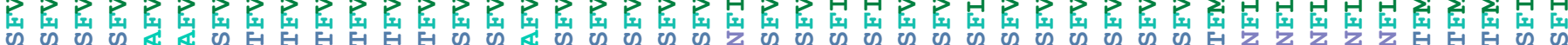

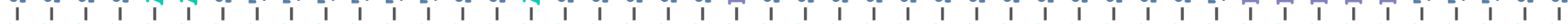

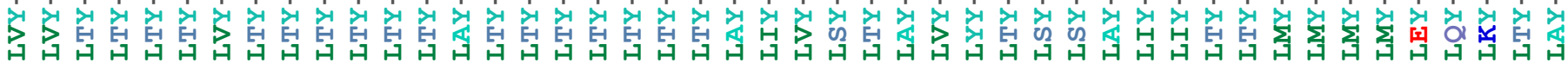

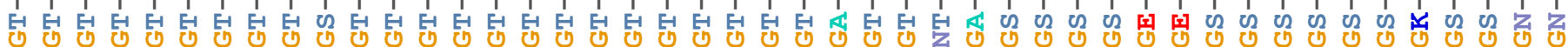

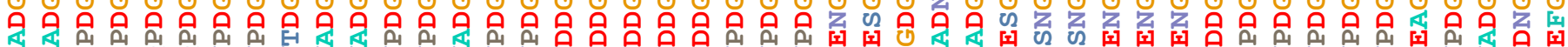

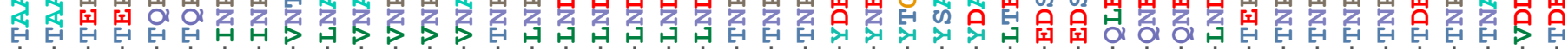
(1)

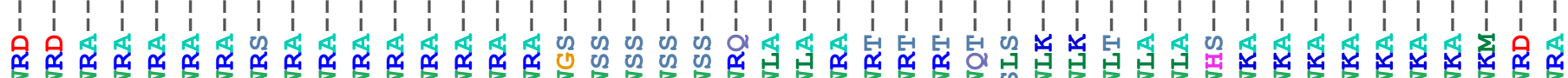

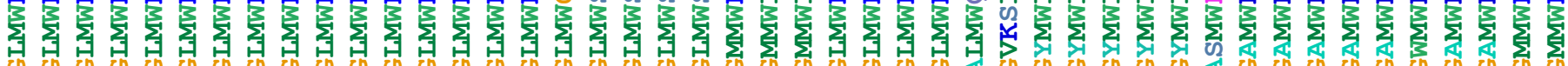

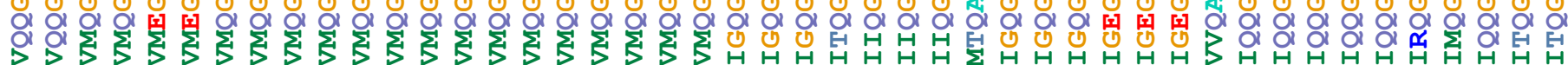

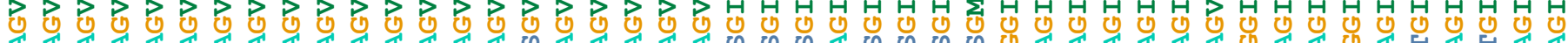

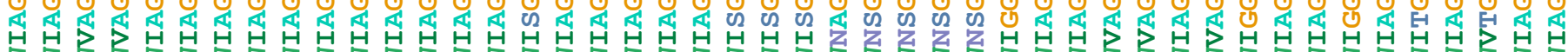

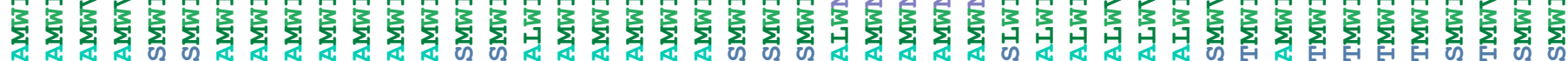

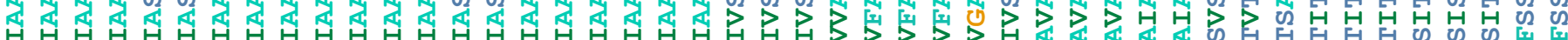

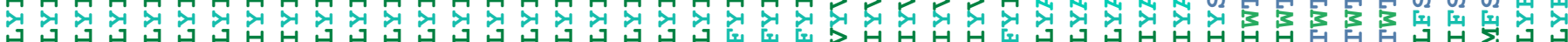

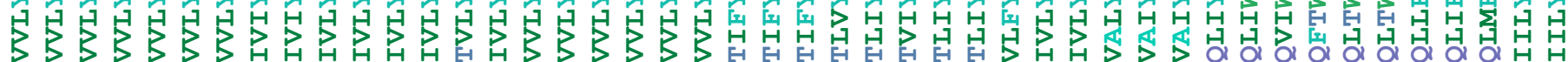

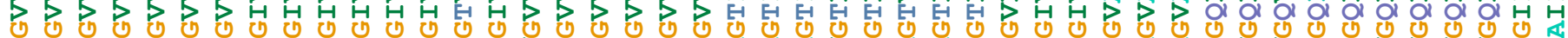
H H H H H H H H H H H H H A B

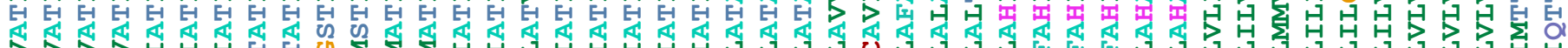

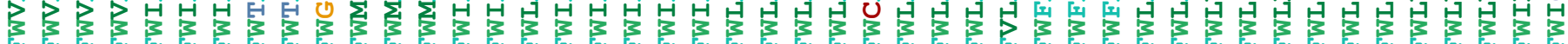

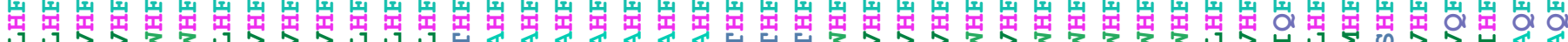

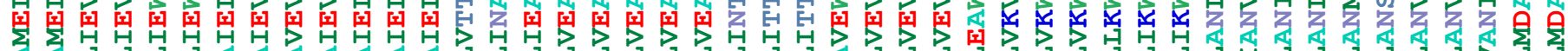

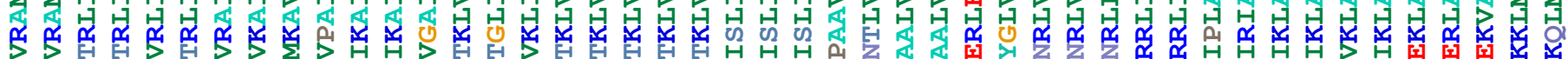

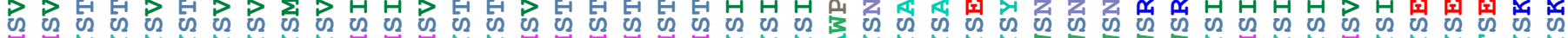

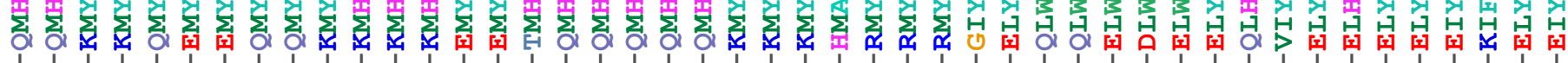

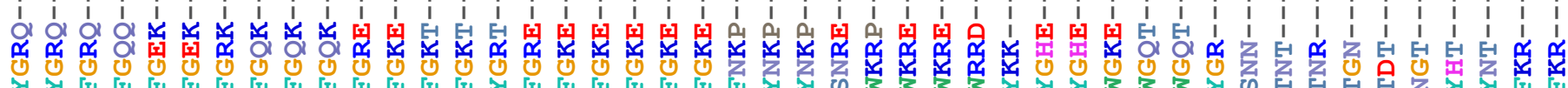

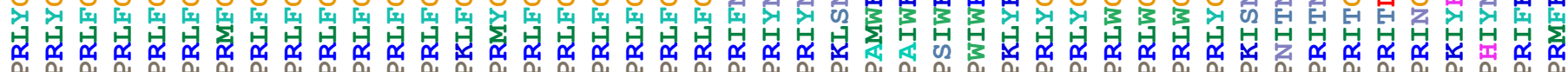

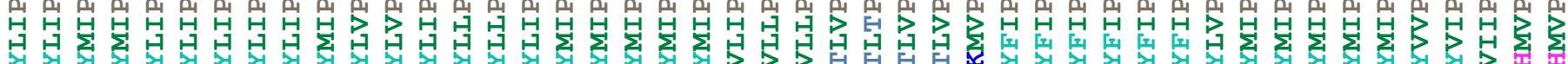

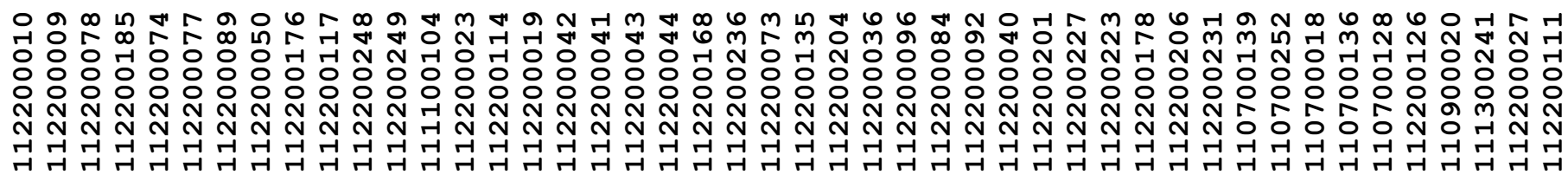




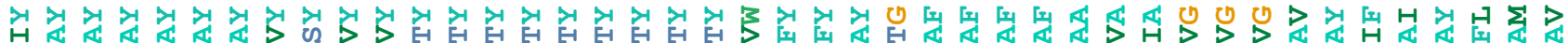

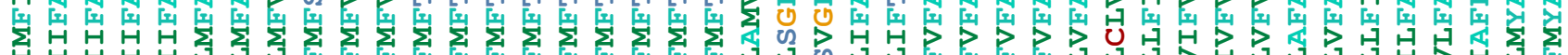

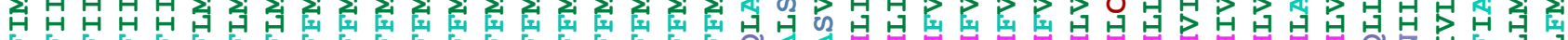

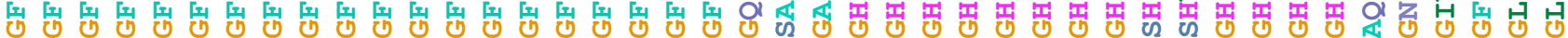

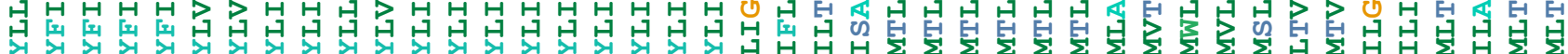

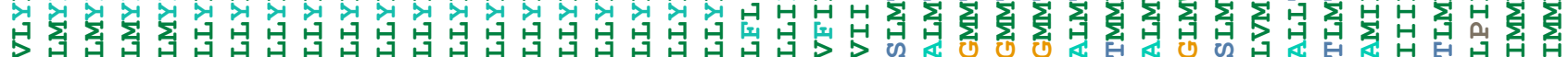

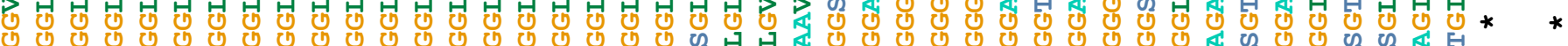

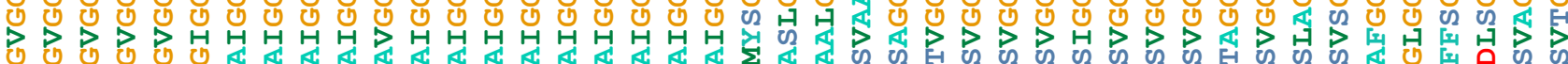

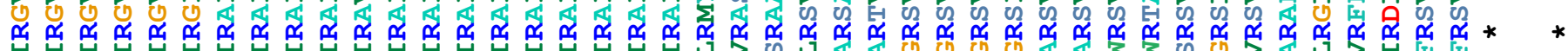

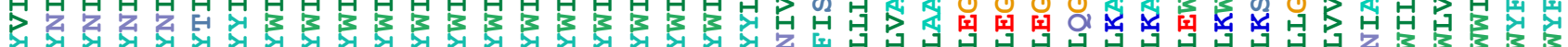

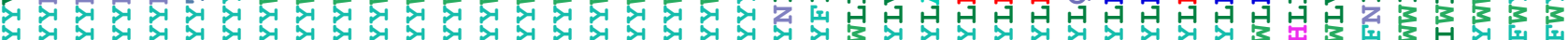

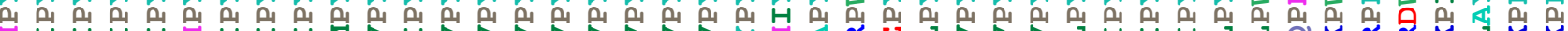

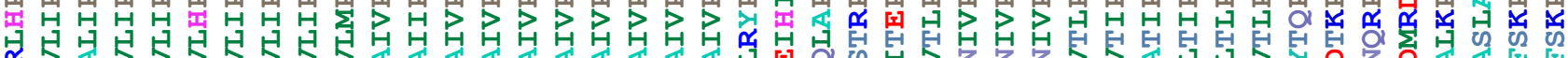

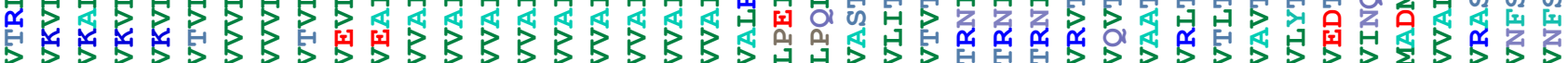

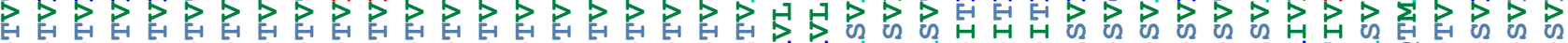
○

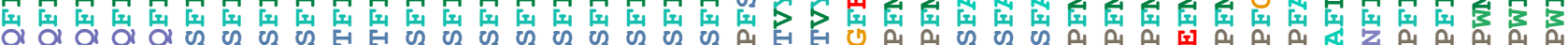

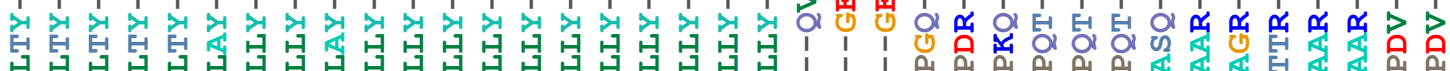

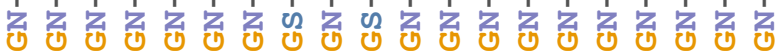

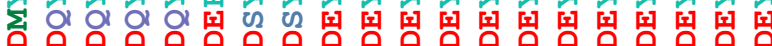

SSS

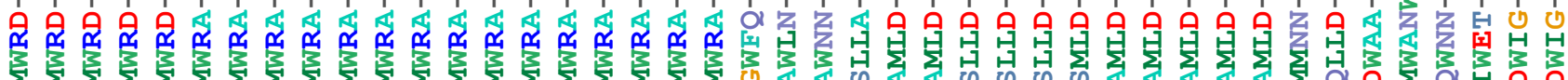

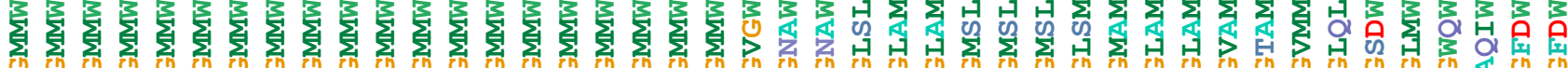

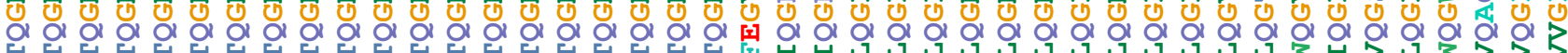

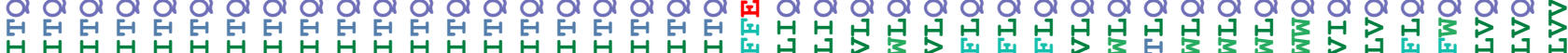

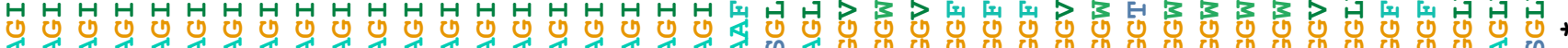

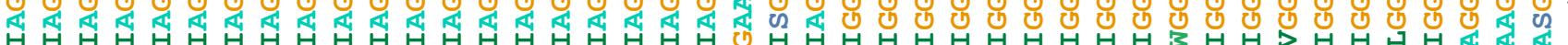

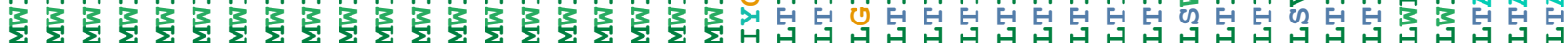

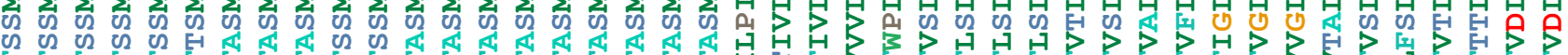

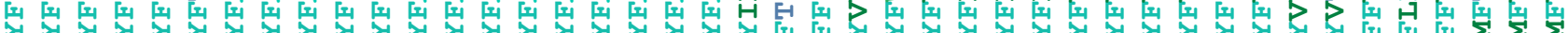

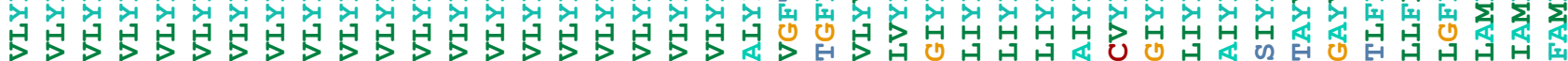

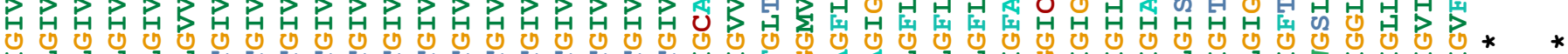

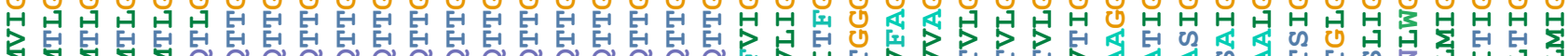

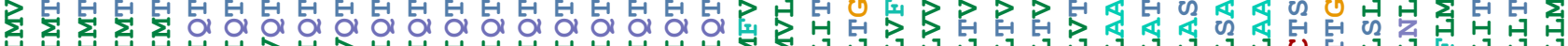

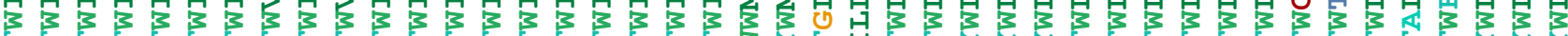
a o o o d a d a d a d a d a d a d

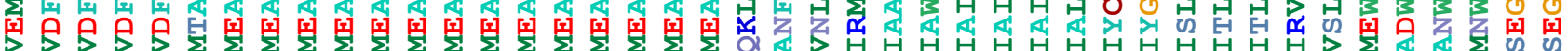

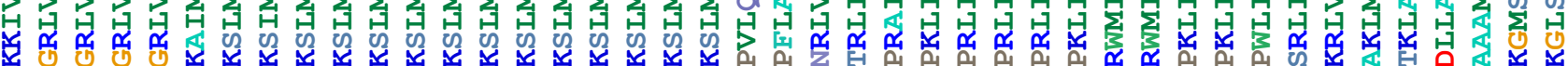

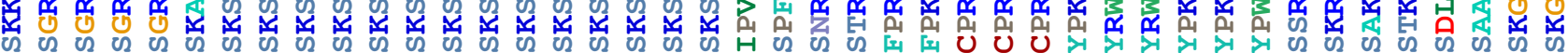

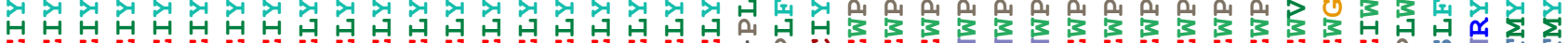

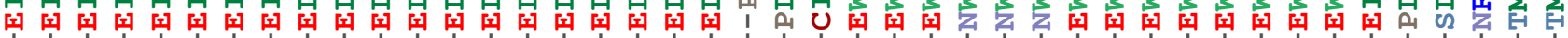

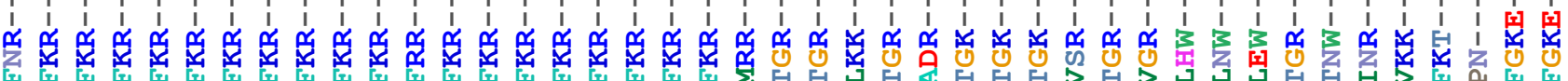

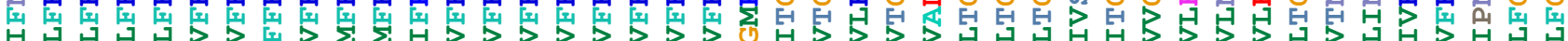

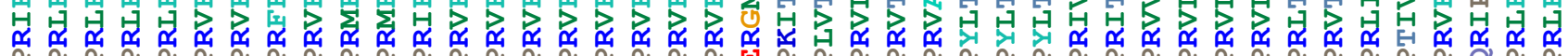

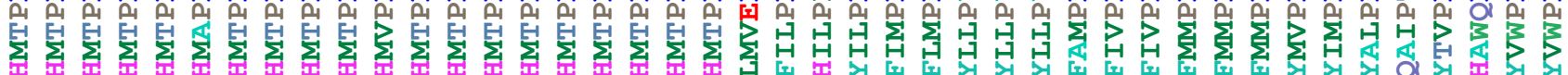

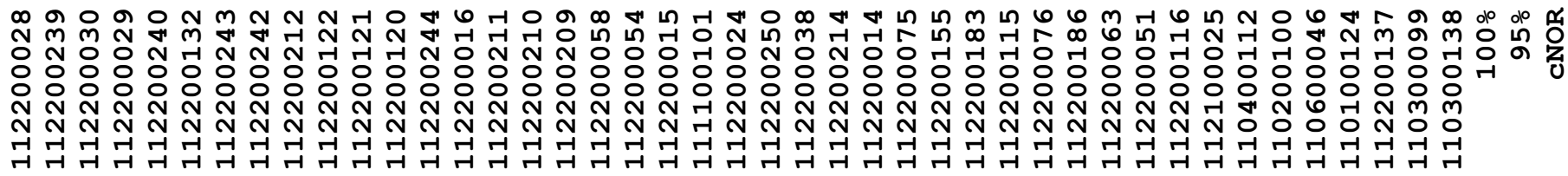




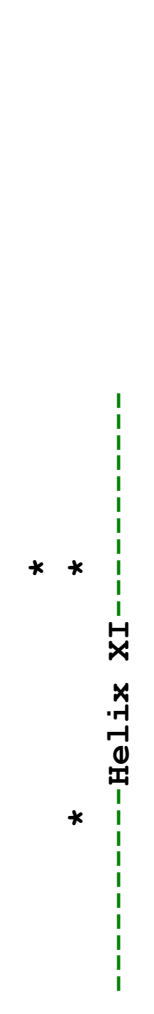

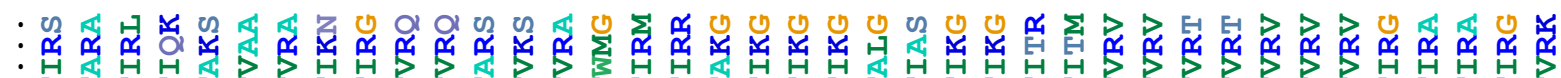

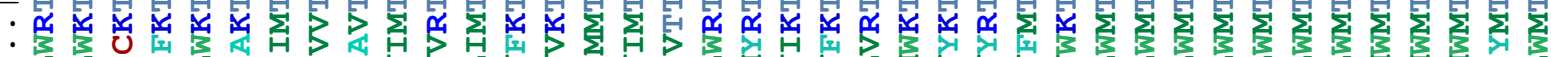

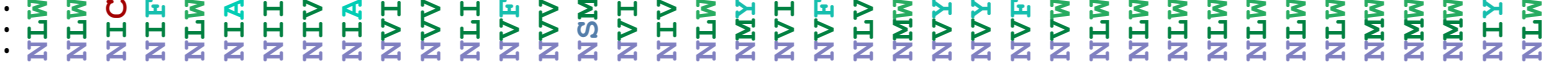




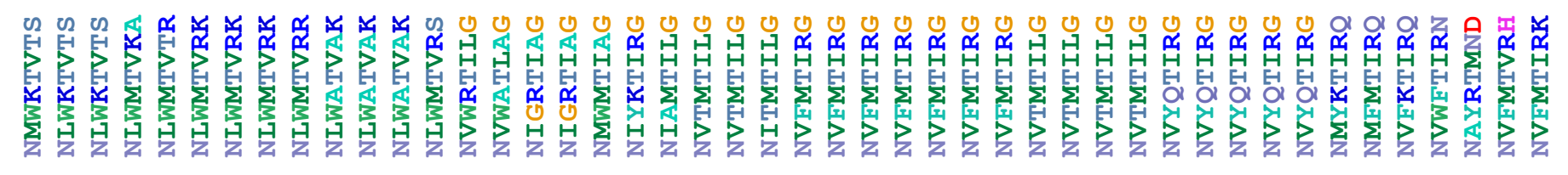
mo네

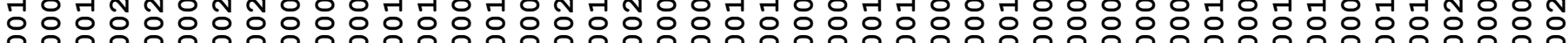

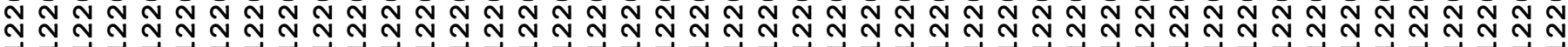

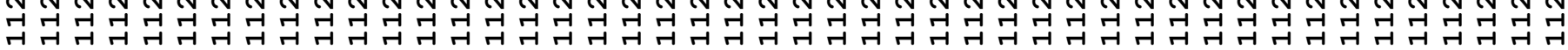




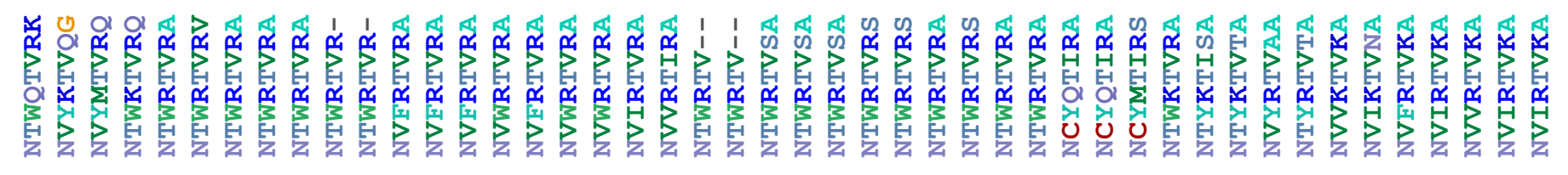
O N

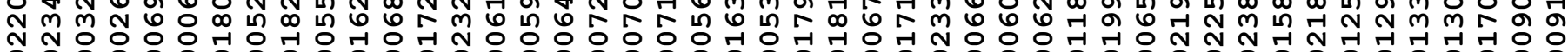

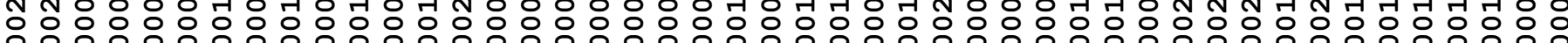

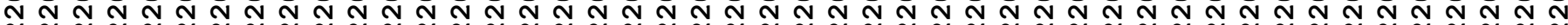

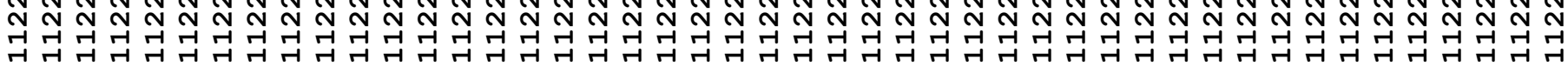




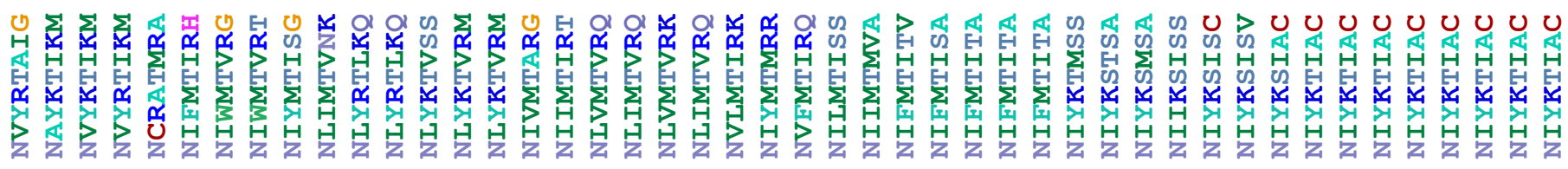
œ

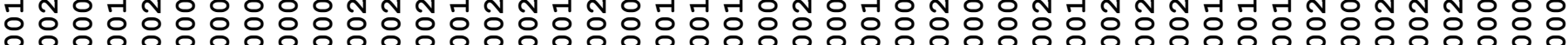
N N N N N N N N N N N N N N T N N N N N N $N$ N N N N N N N N N N N

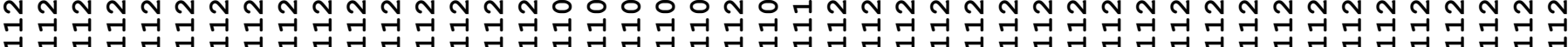




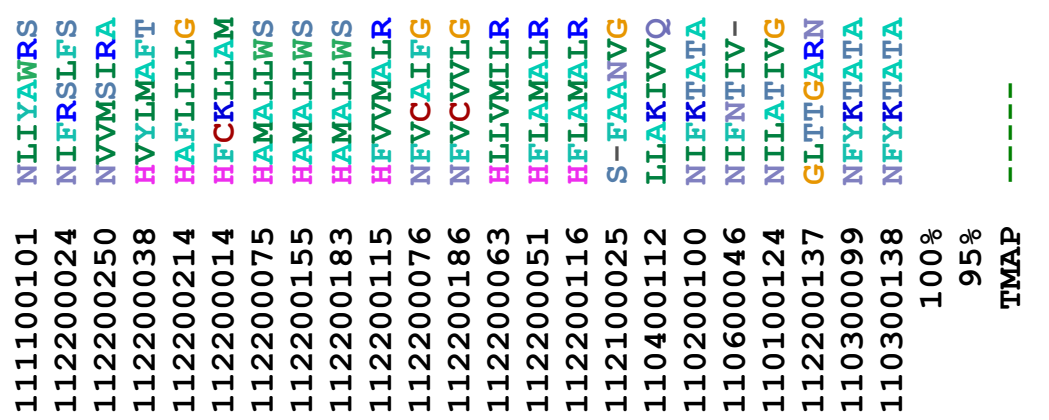




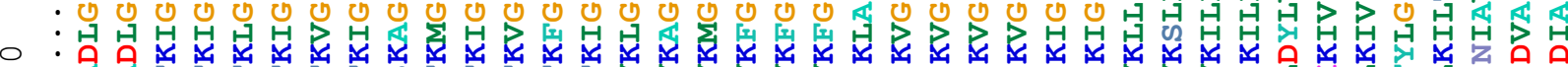

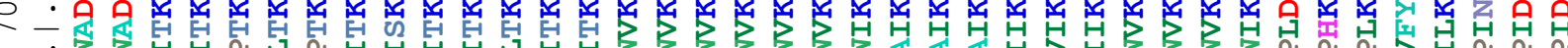

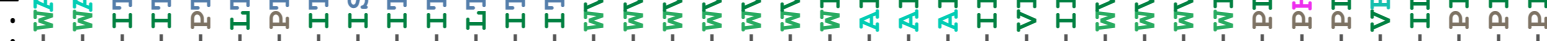

들

事

¿

in

U

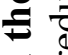

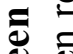

3 क

칭

$\geq$

를 思

$\Xi \stackrel{0}{\Xi}$

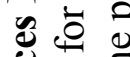

曲

.

- ه

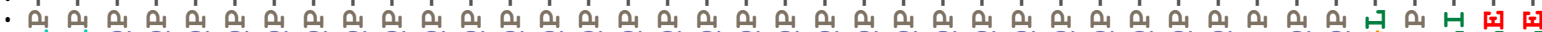

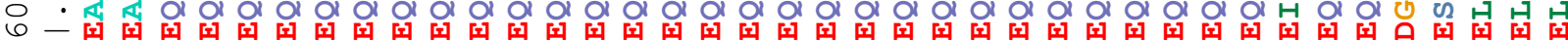
-

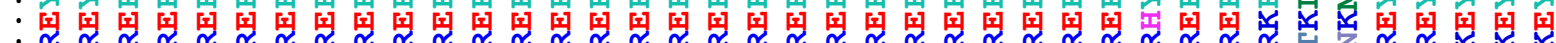

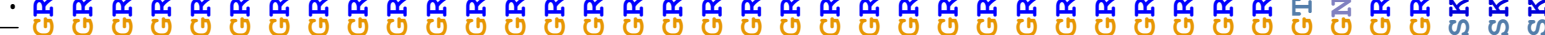

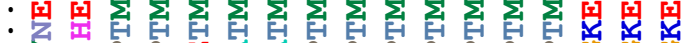

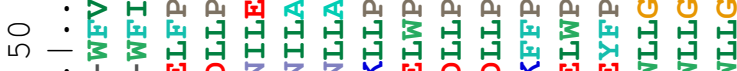

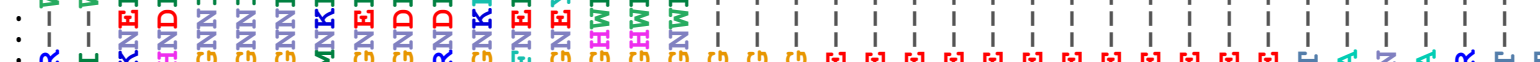

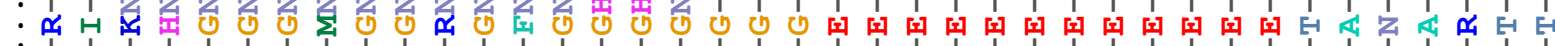
운

.

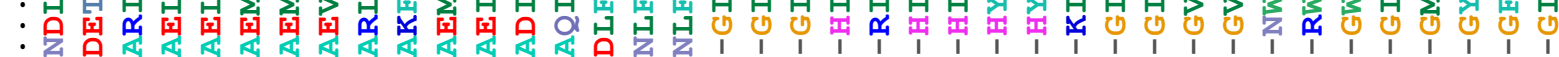

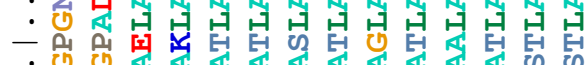

:

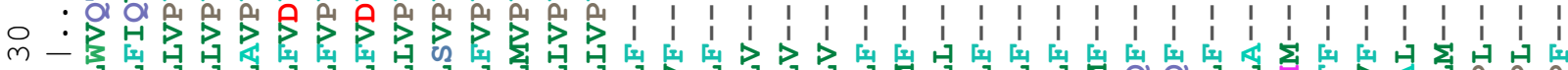

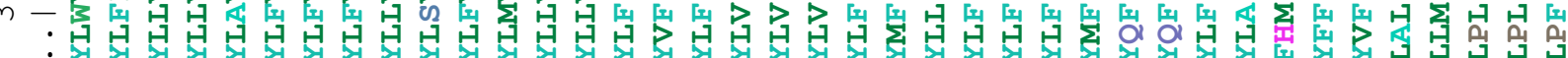
: 2 S D

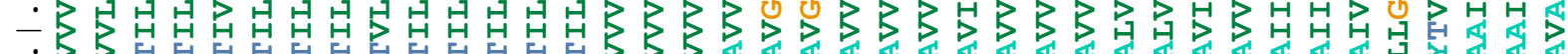

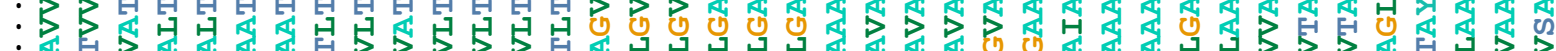

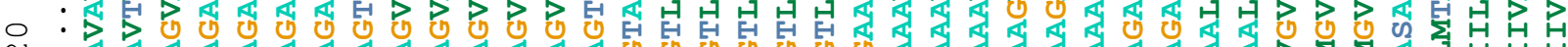

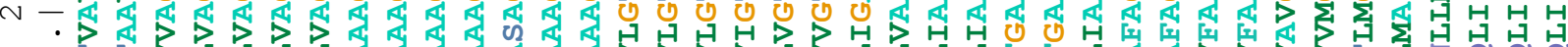

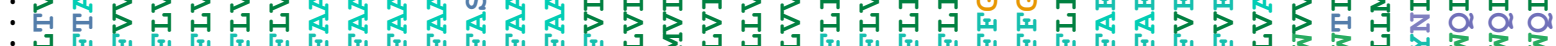

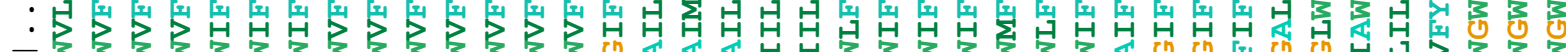

-

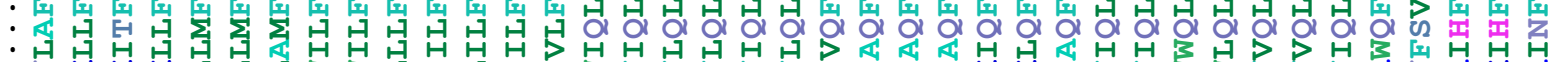

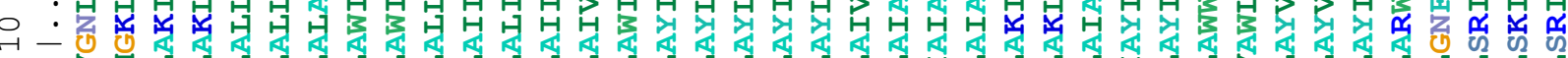

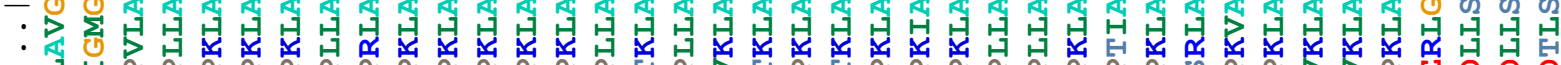

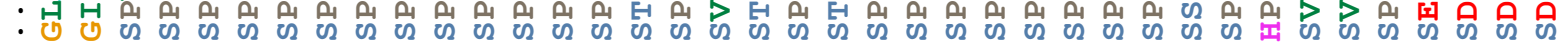

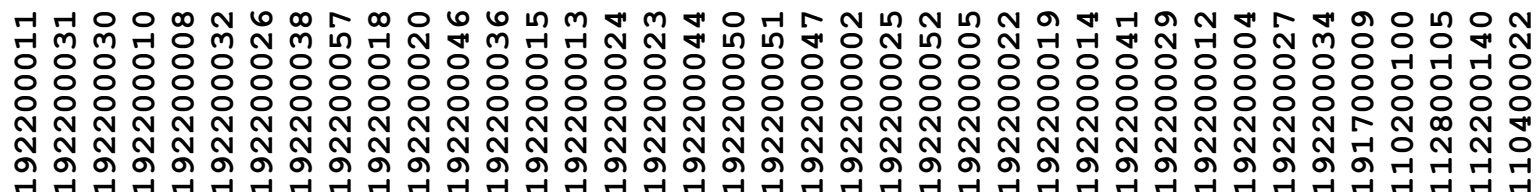




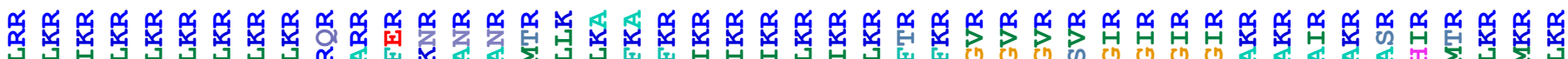

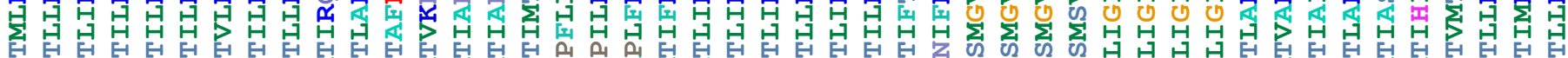

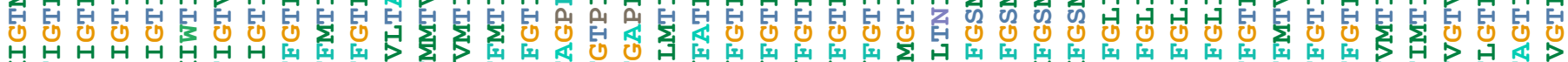

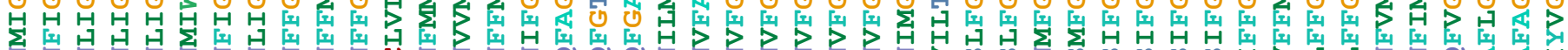

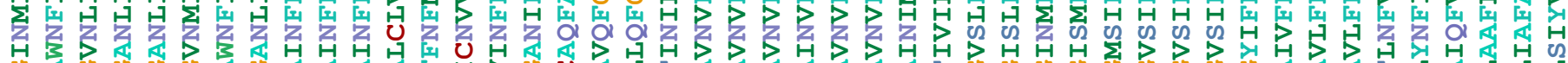

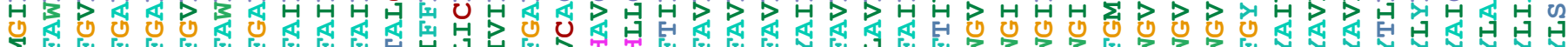

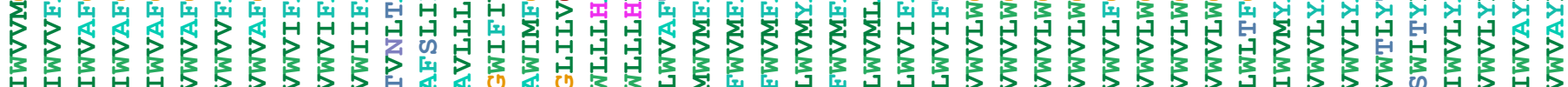

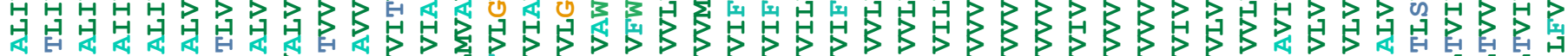

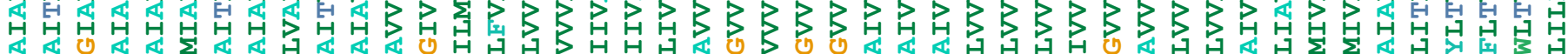

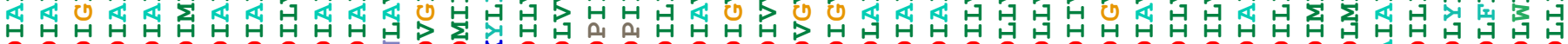

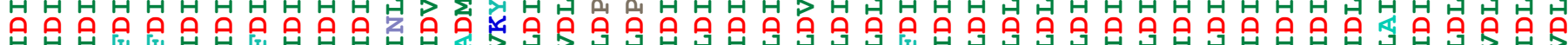

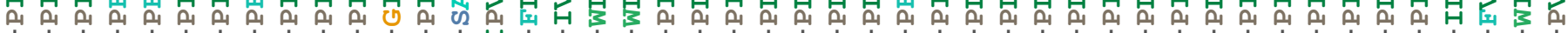

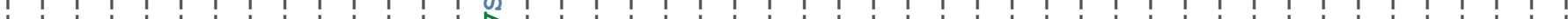

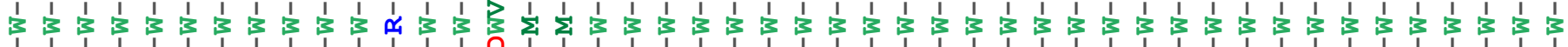

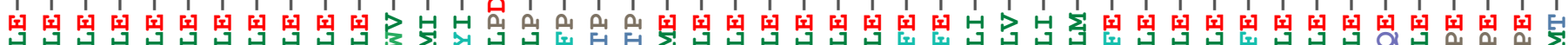

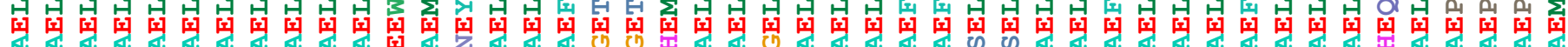

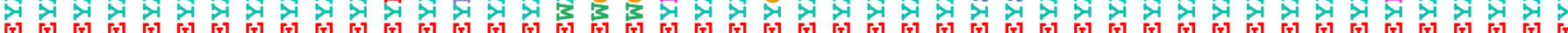

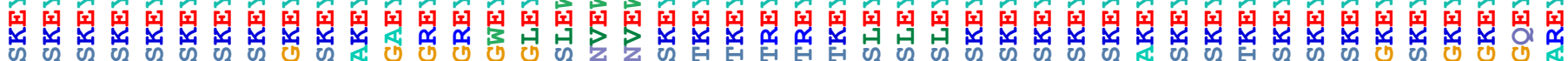

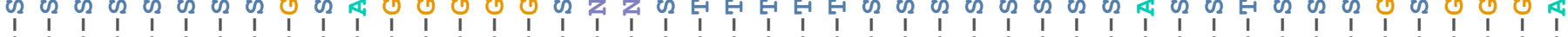

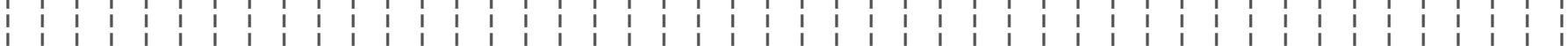

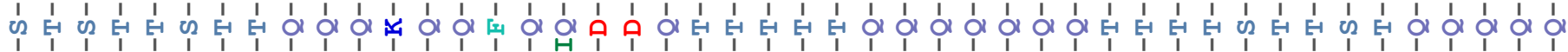

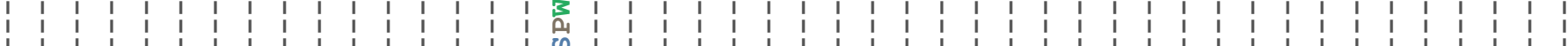

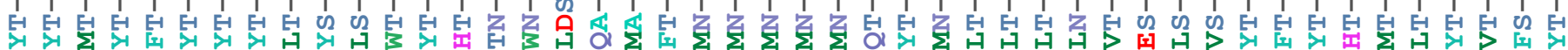

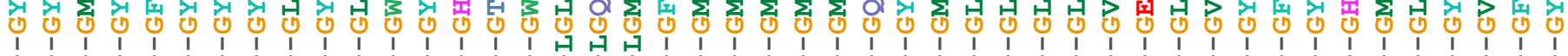

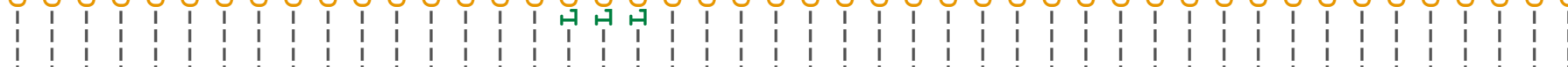

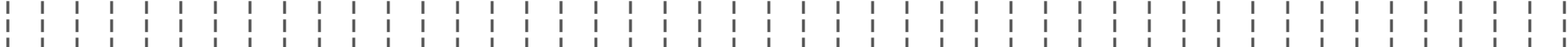

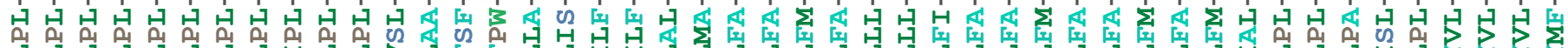

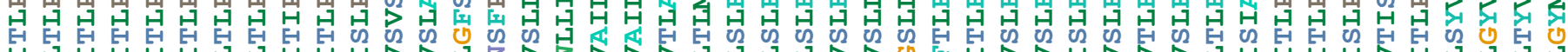

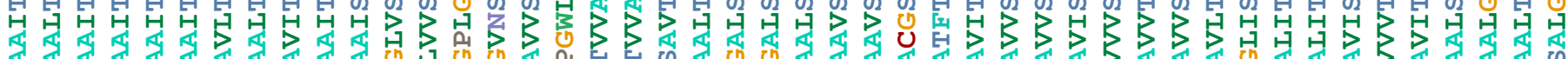

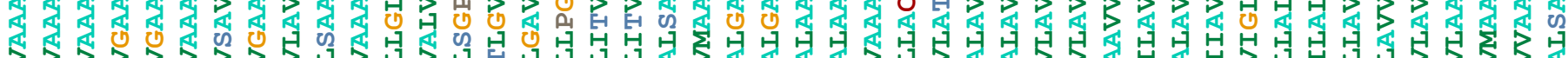

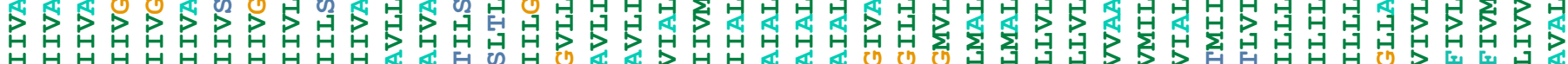

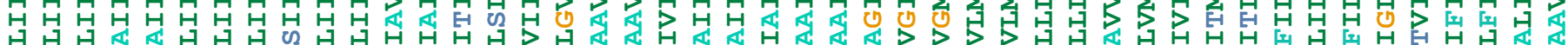

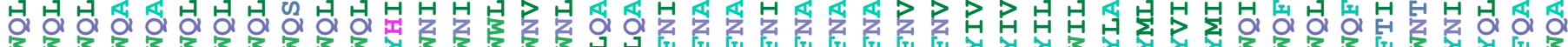

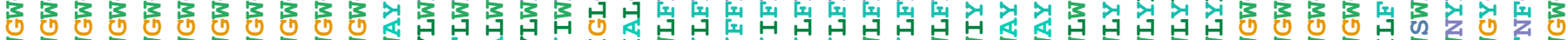

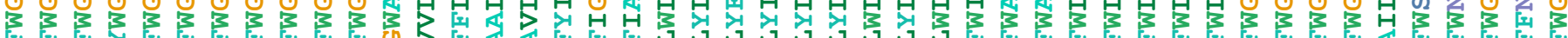

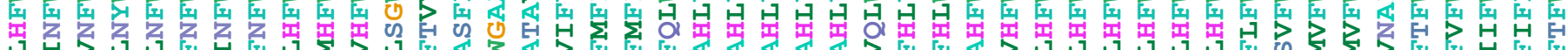

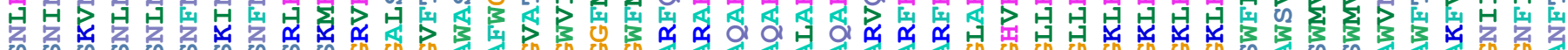
ผ

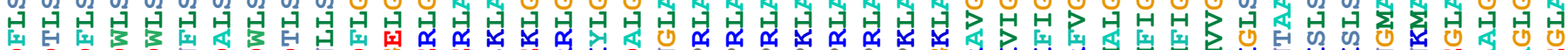

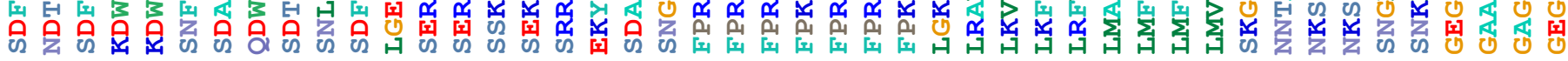

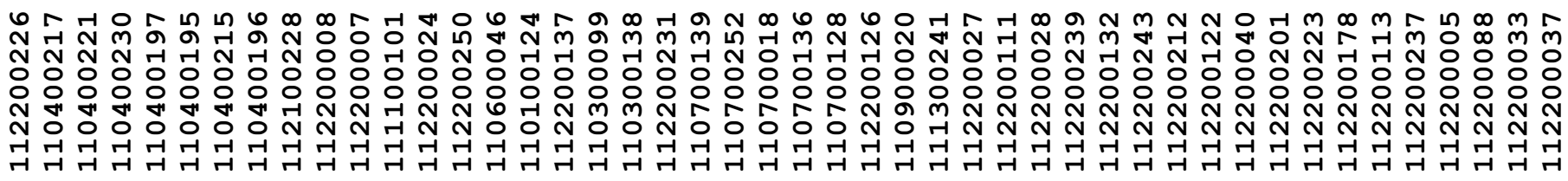




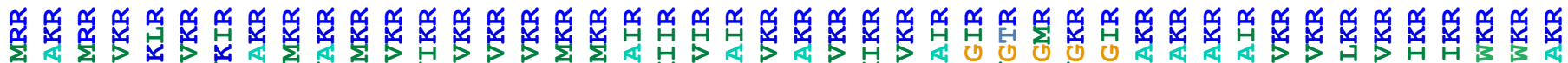

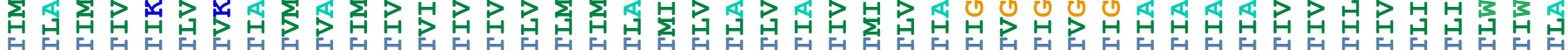

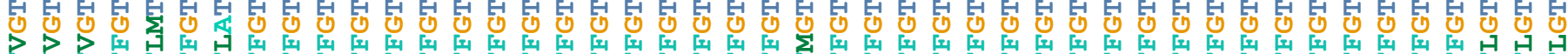

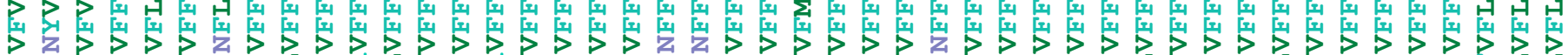

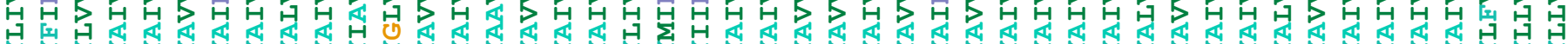

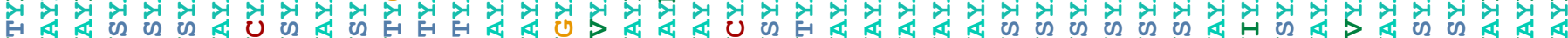

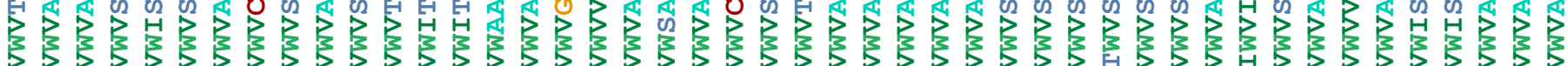

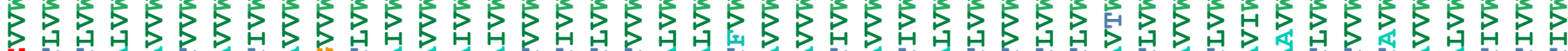

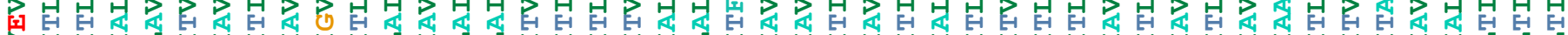
SHA H

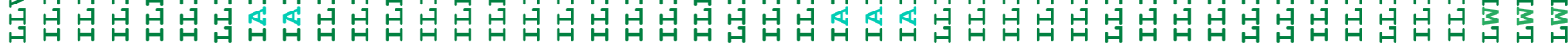

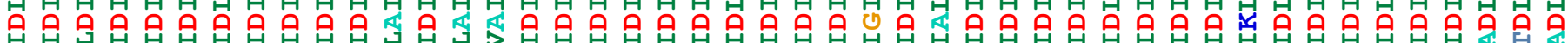

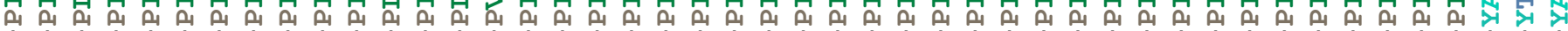

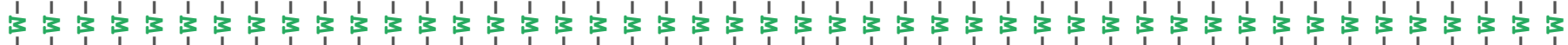

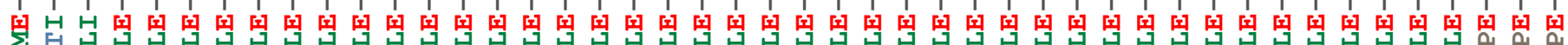

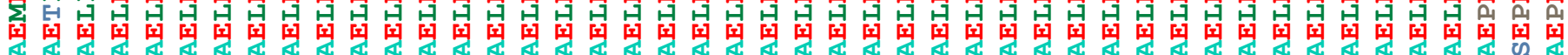

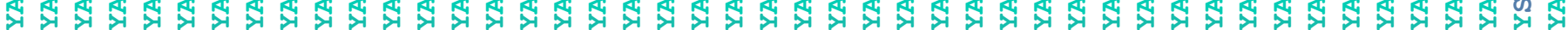

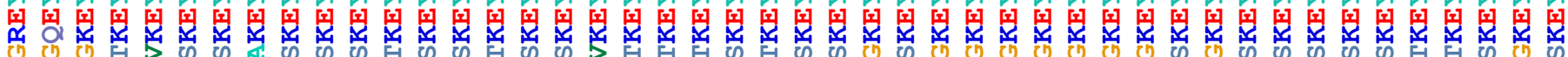

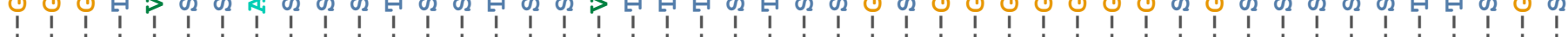

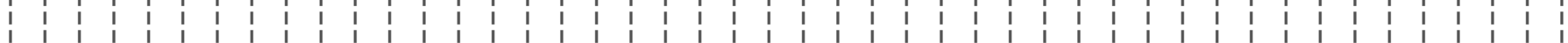

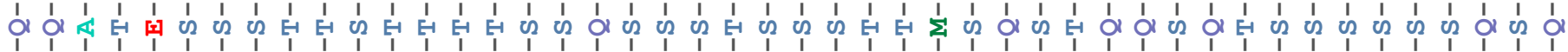

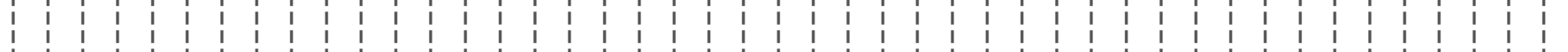

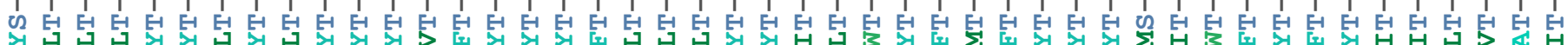

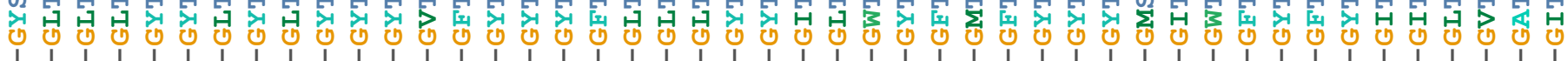

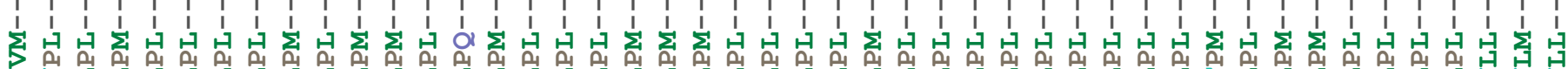

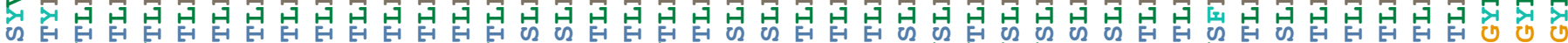

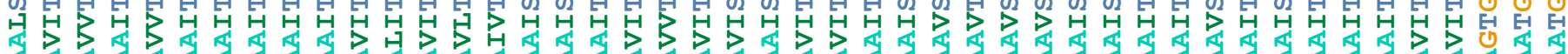

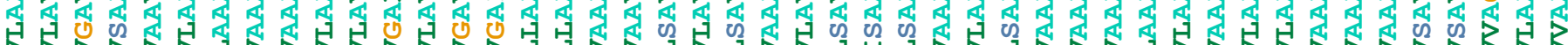

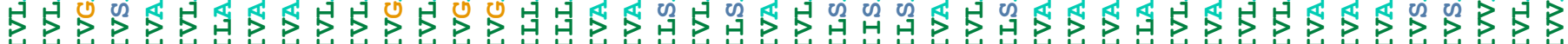

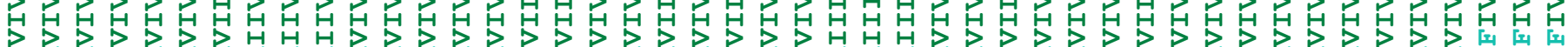

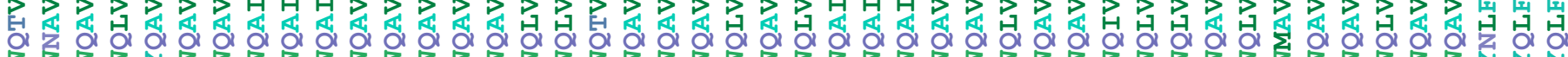

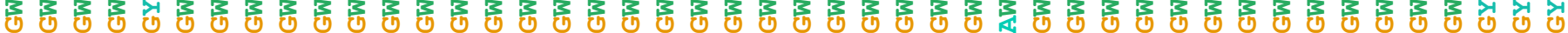

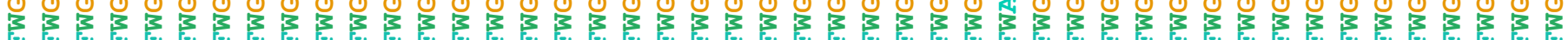

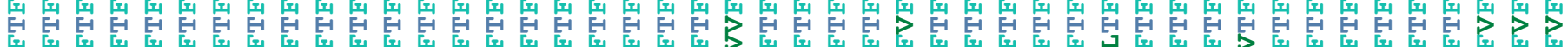

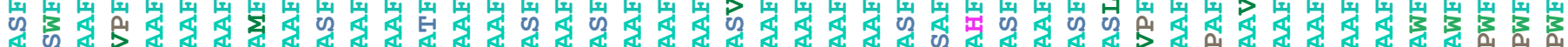

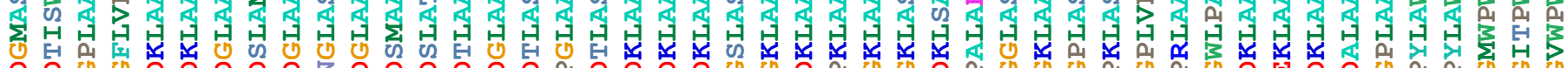

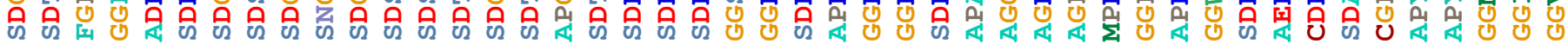

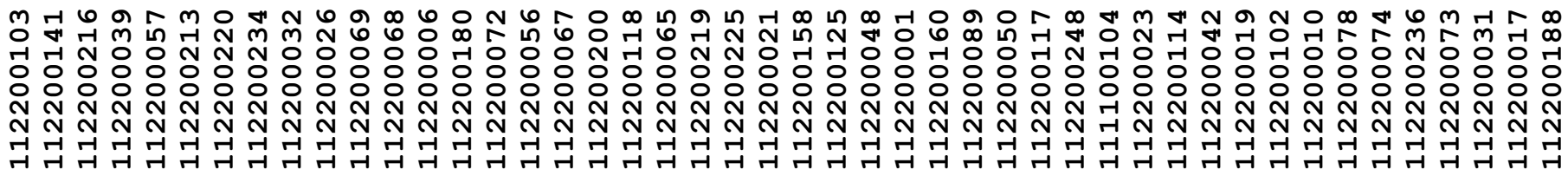




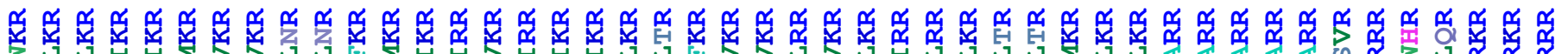

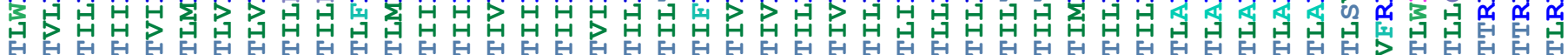

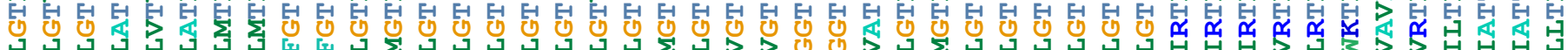

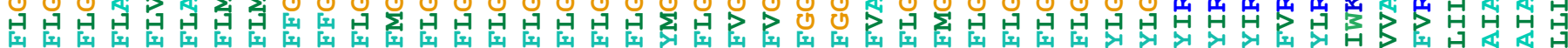

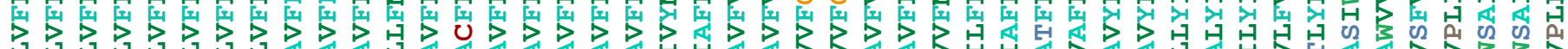

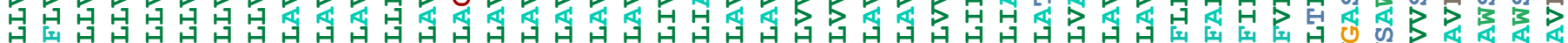

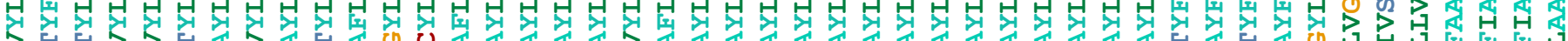

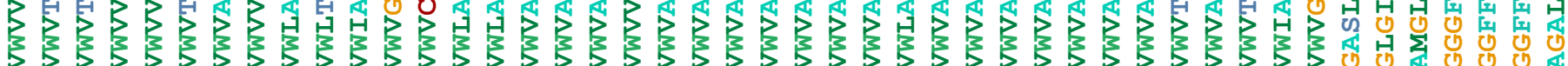

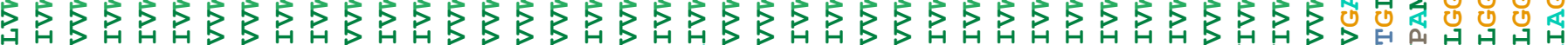

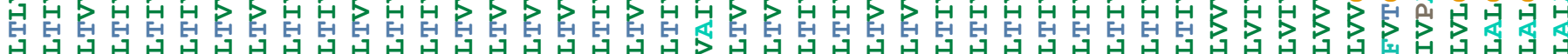

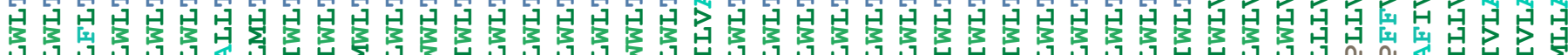

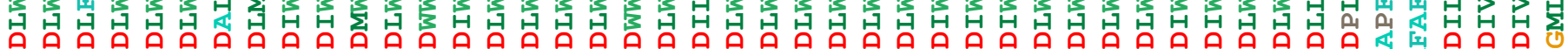

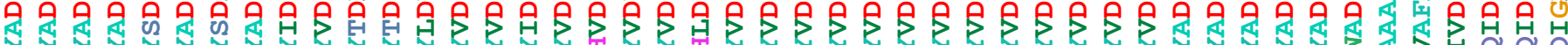

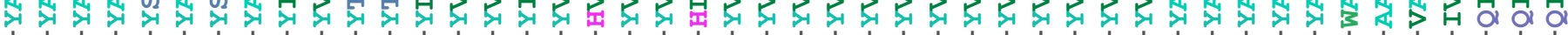

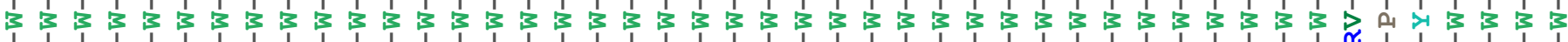

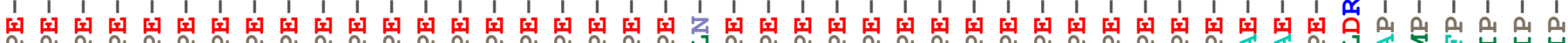

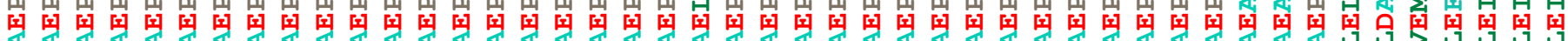

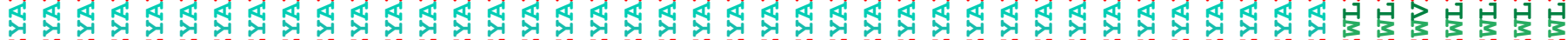

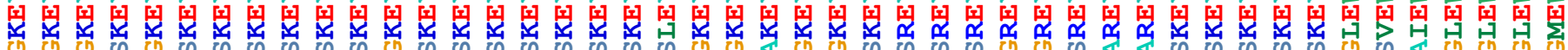

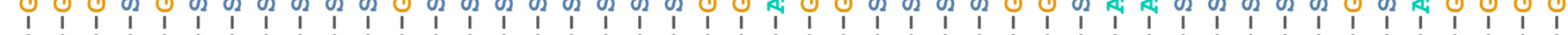

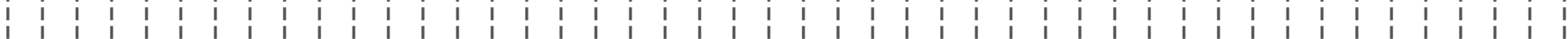

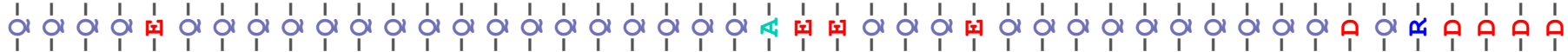

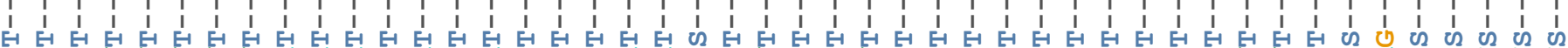

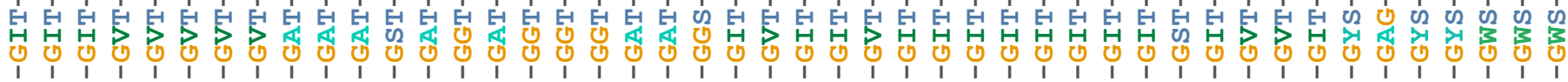

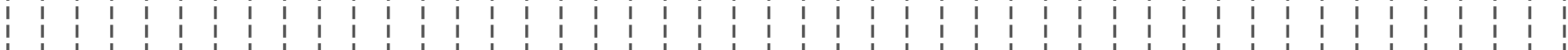

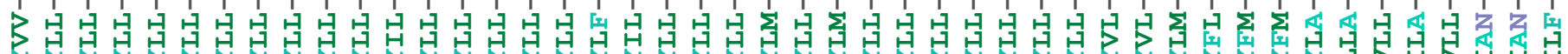

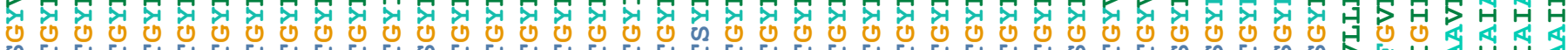

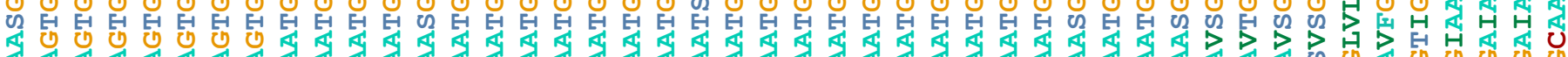

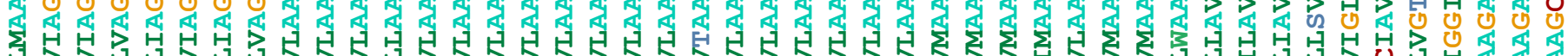

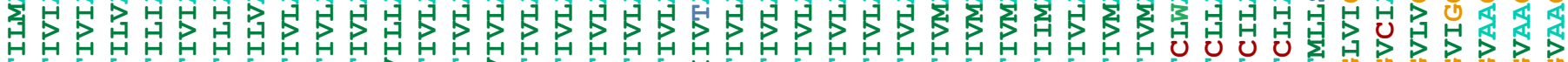

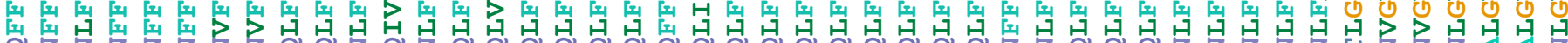

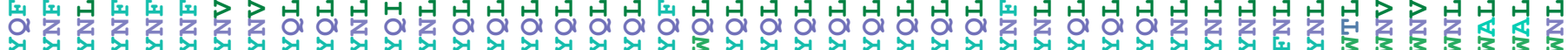

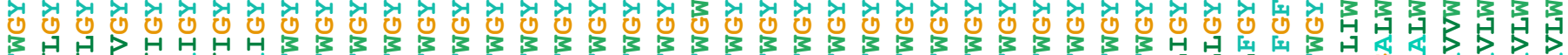

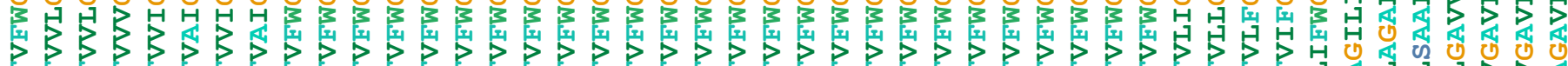

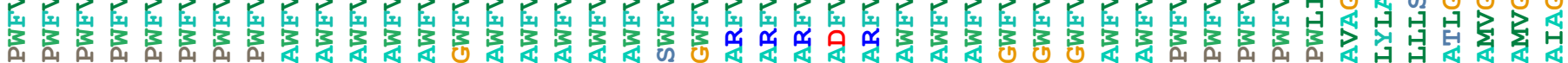

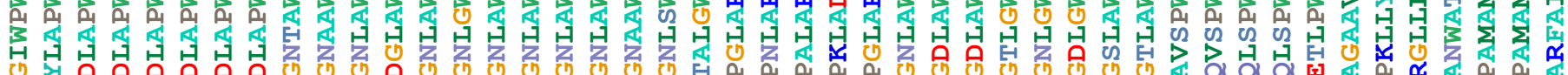

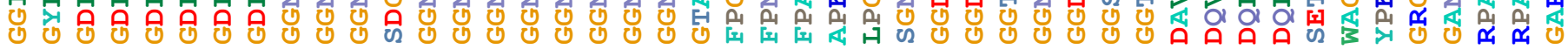

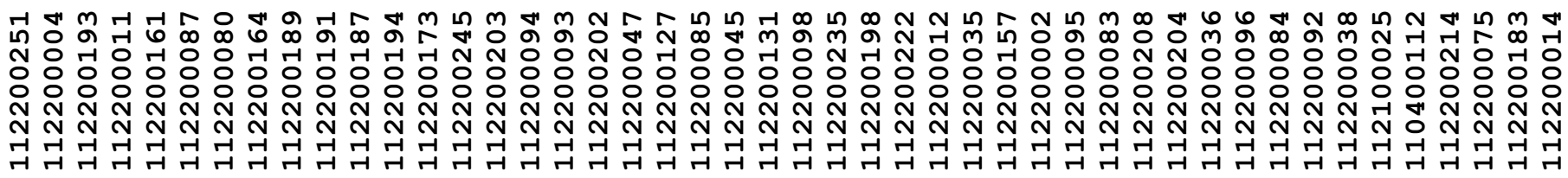




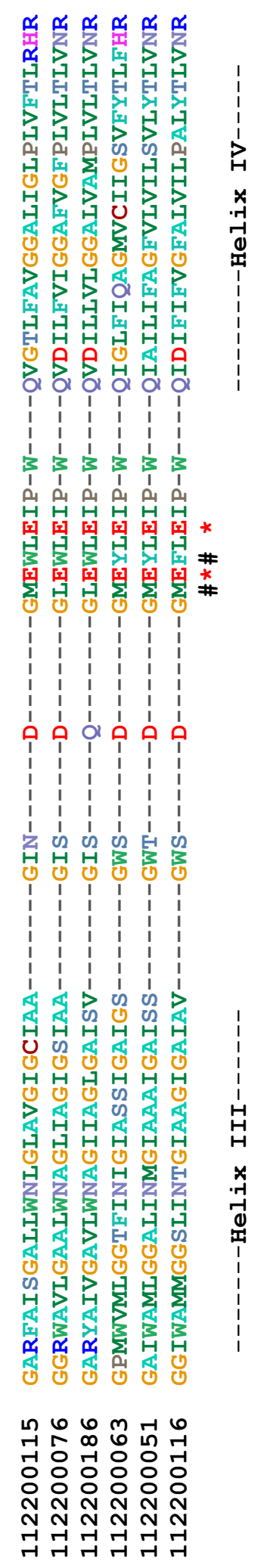




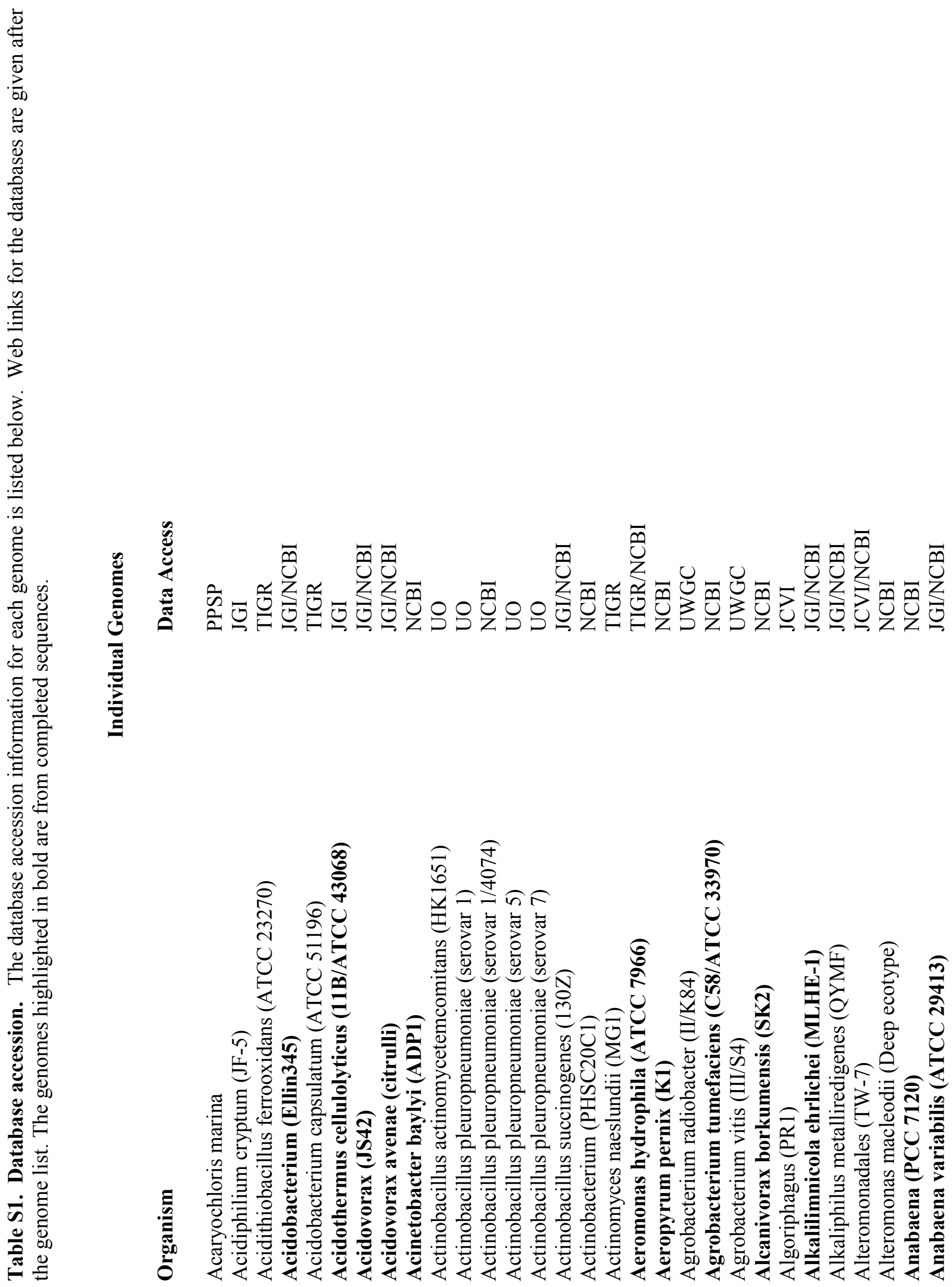




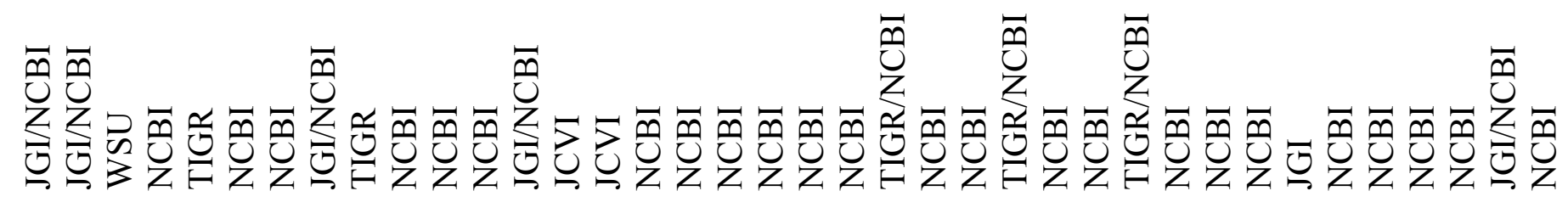

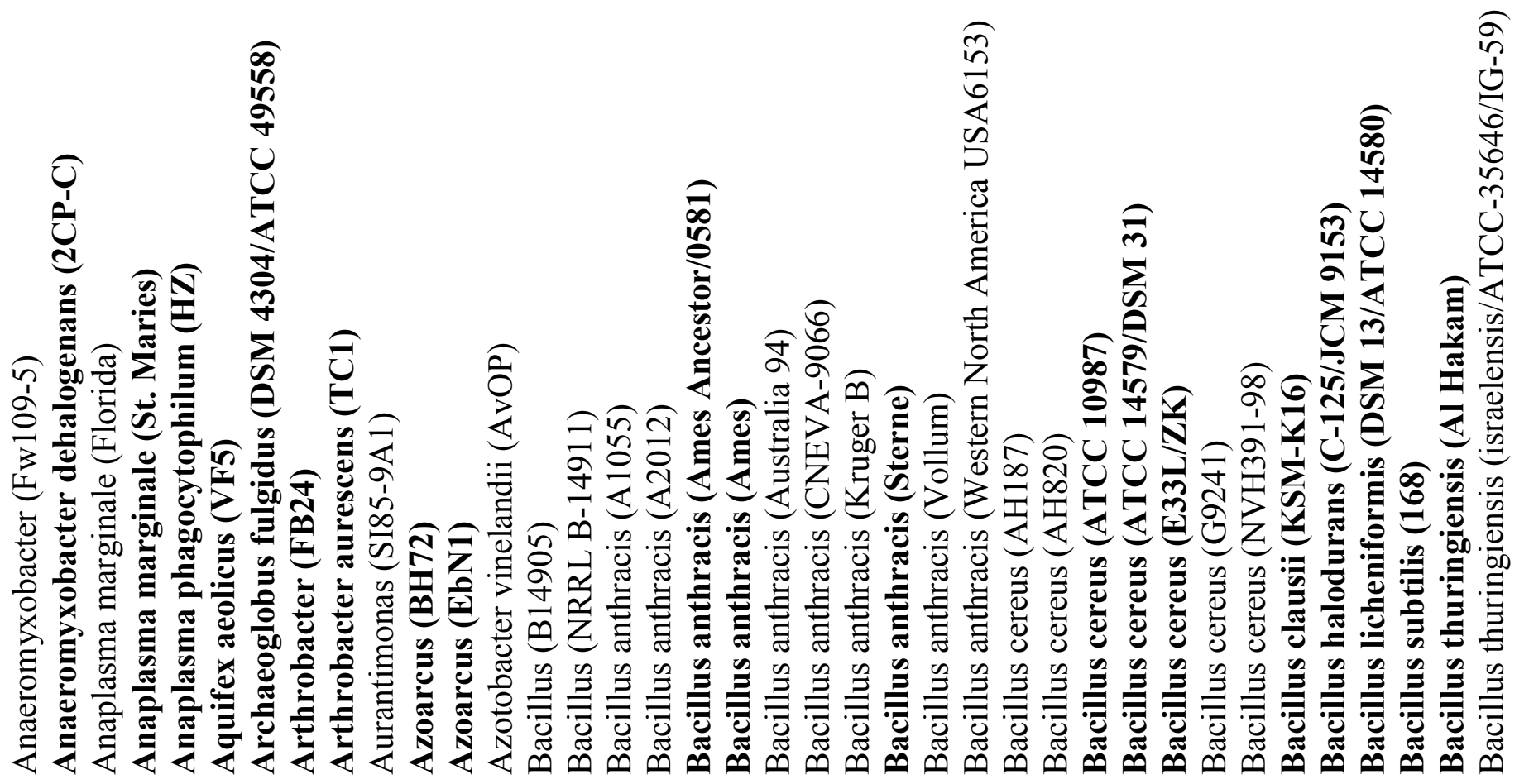




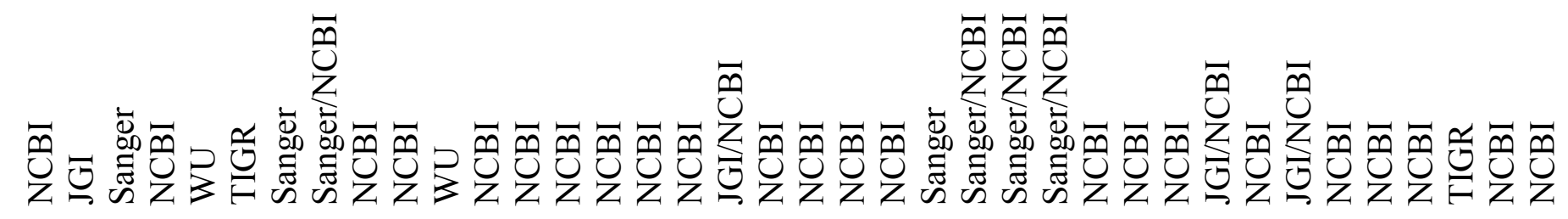

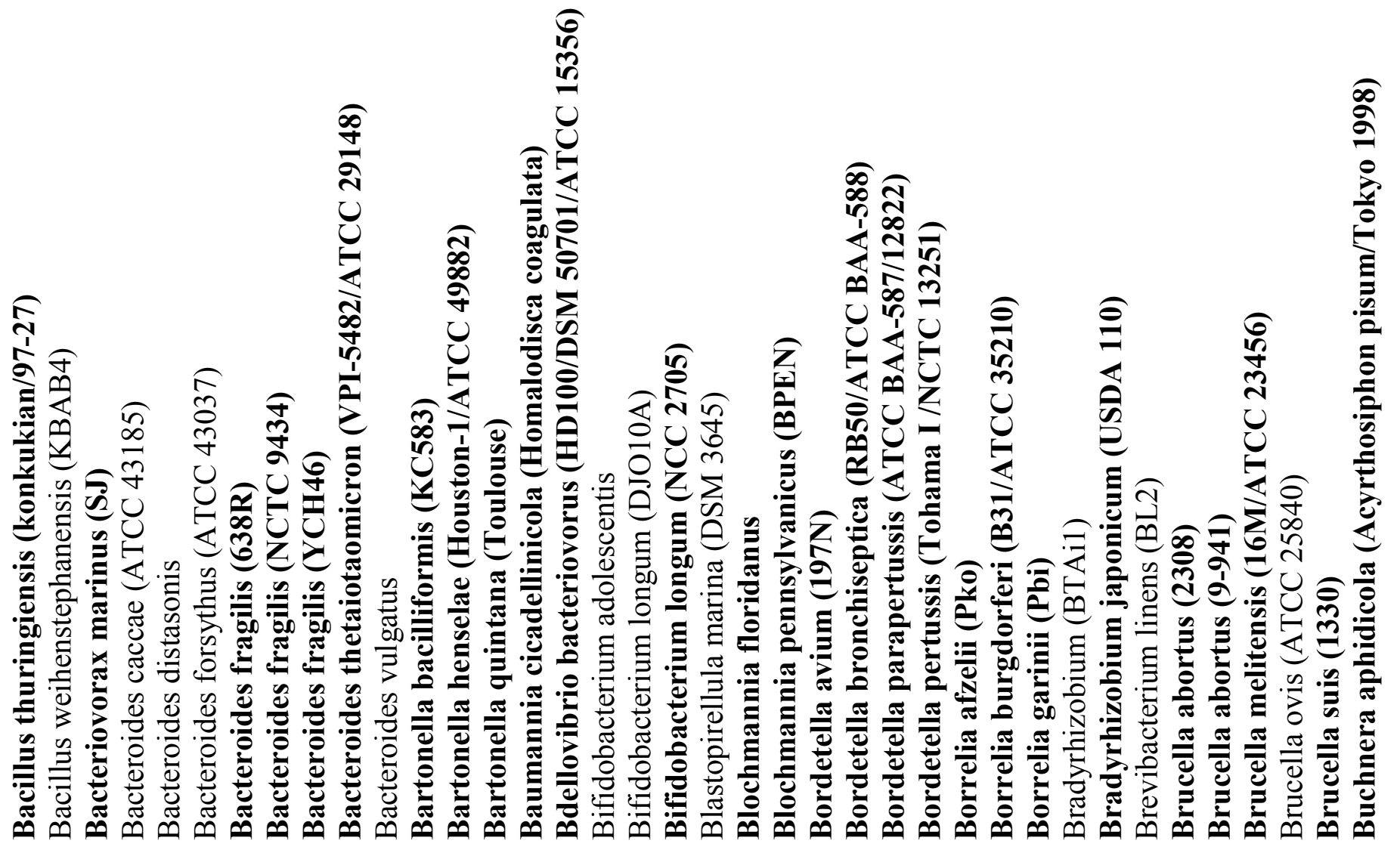




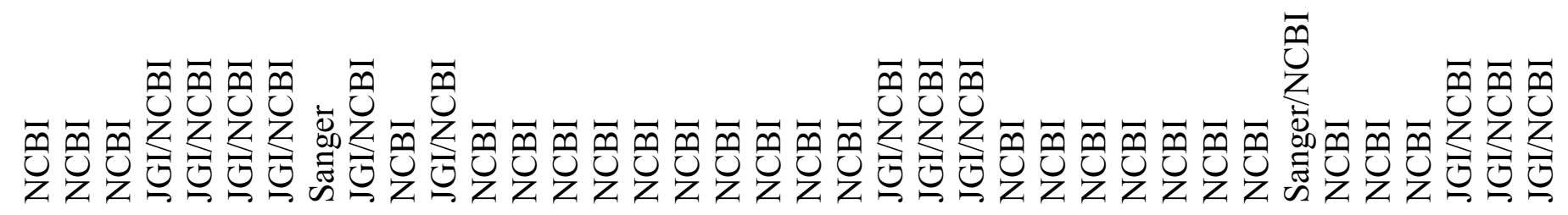

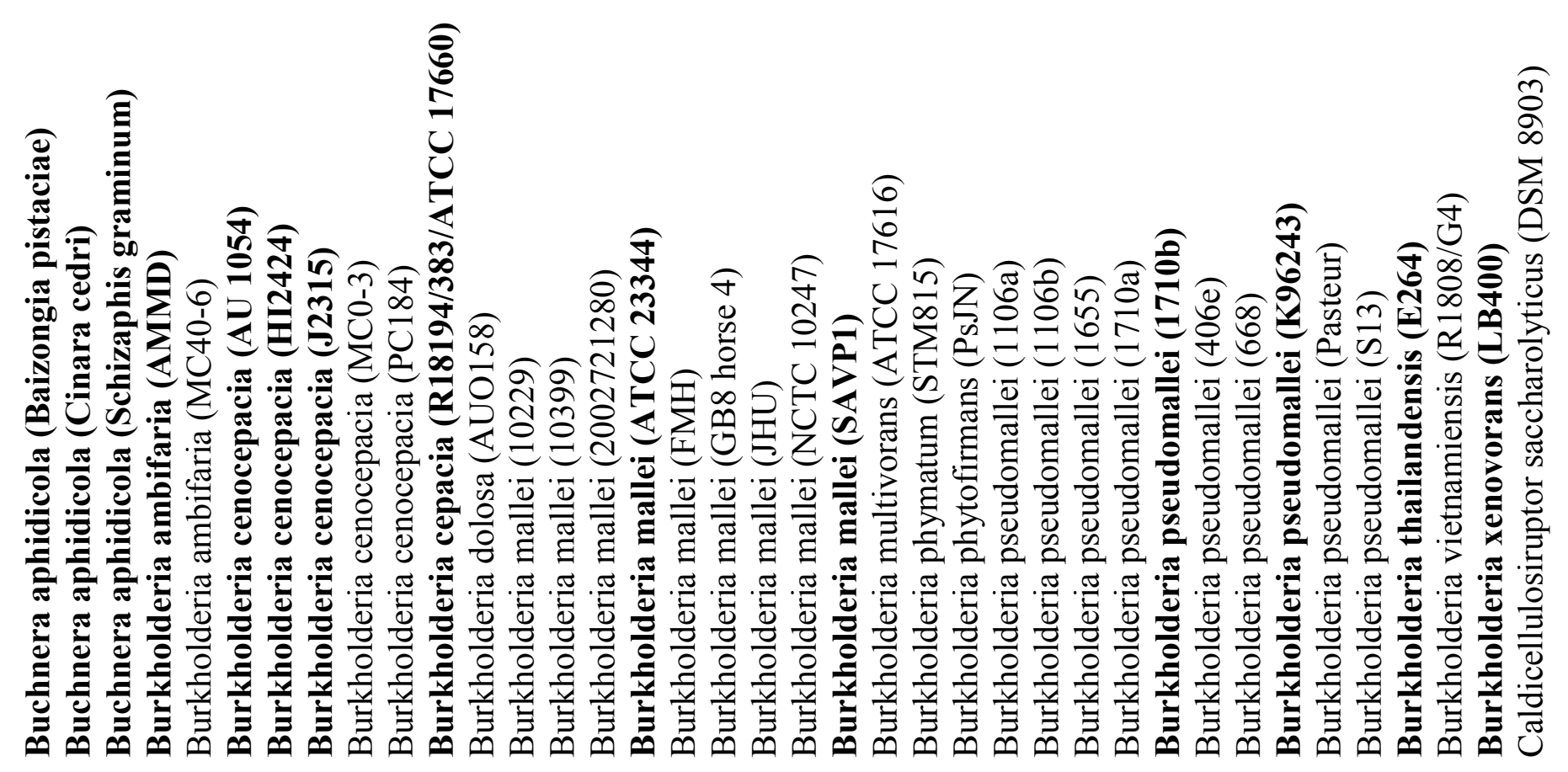




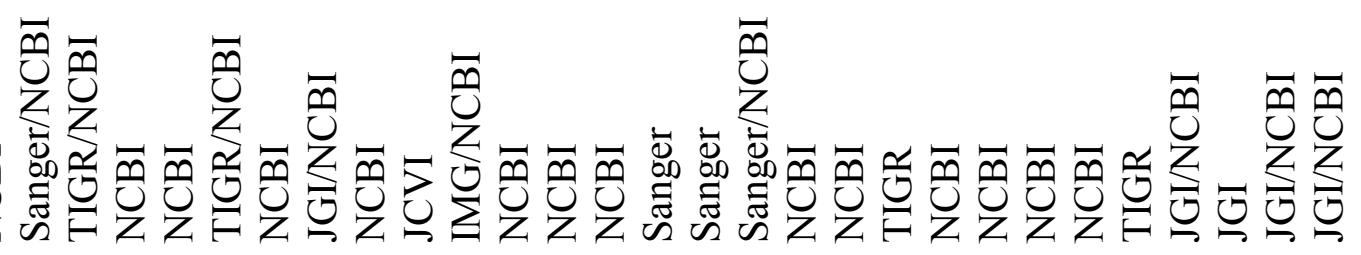

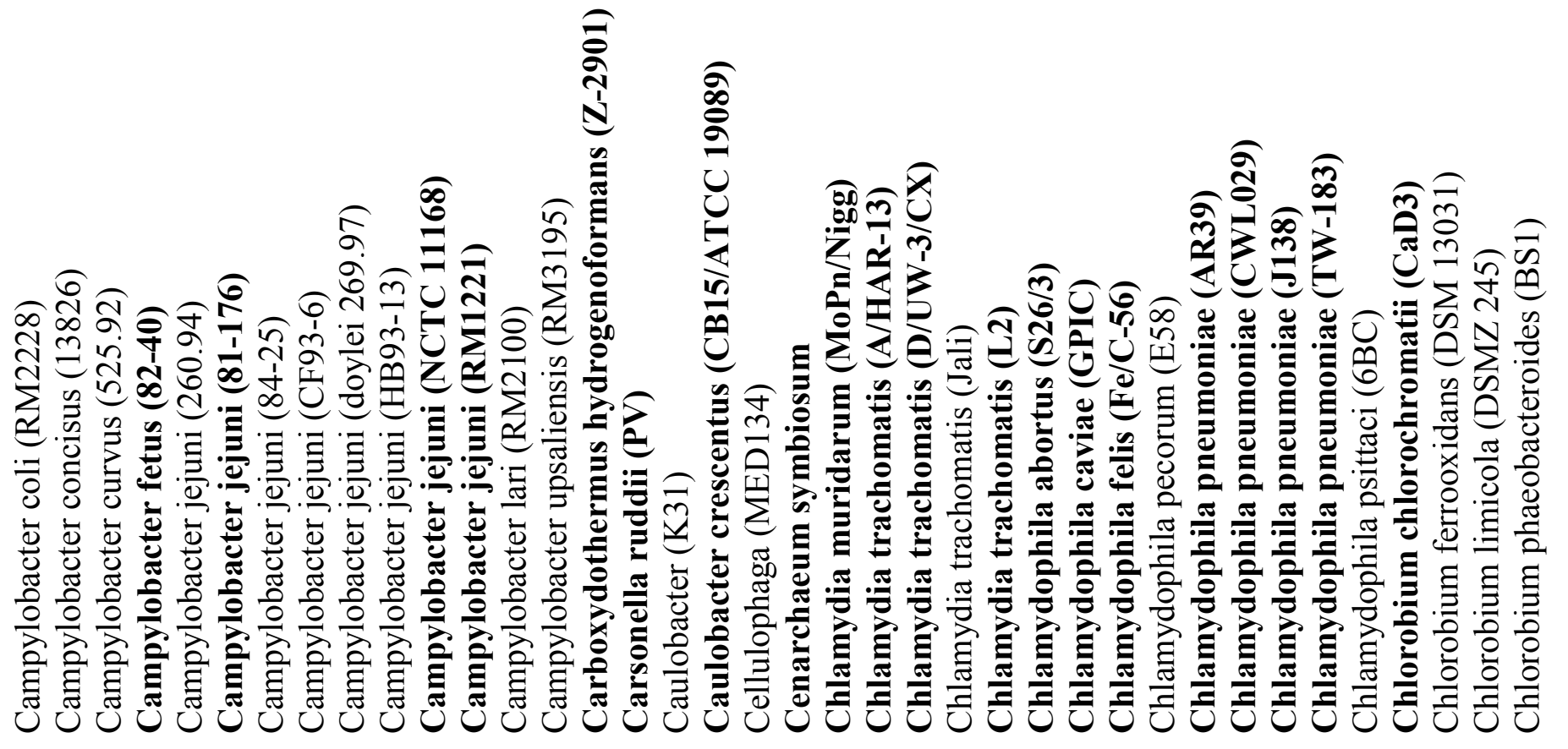




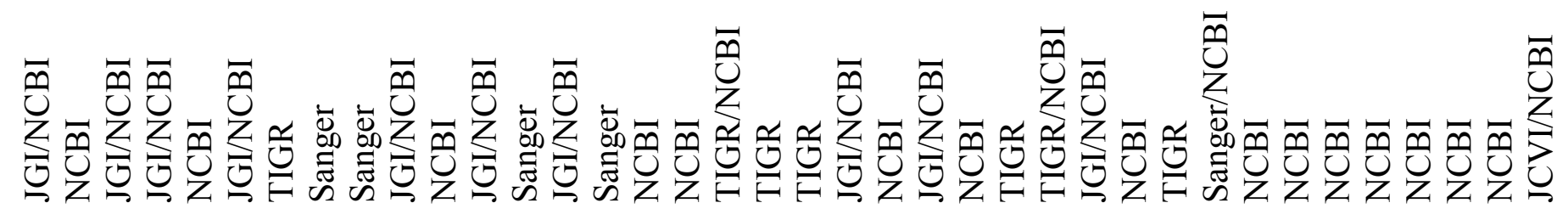

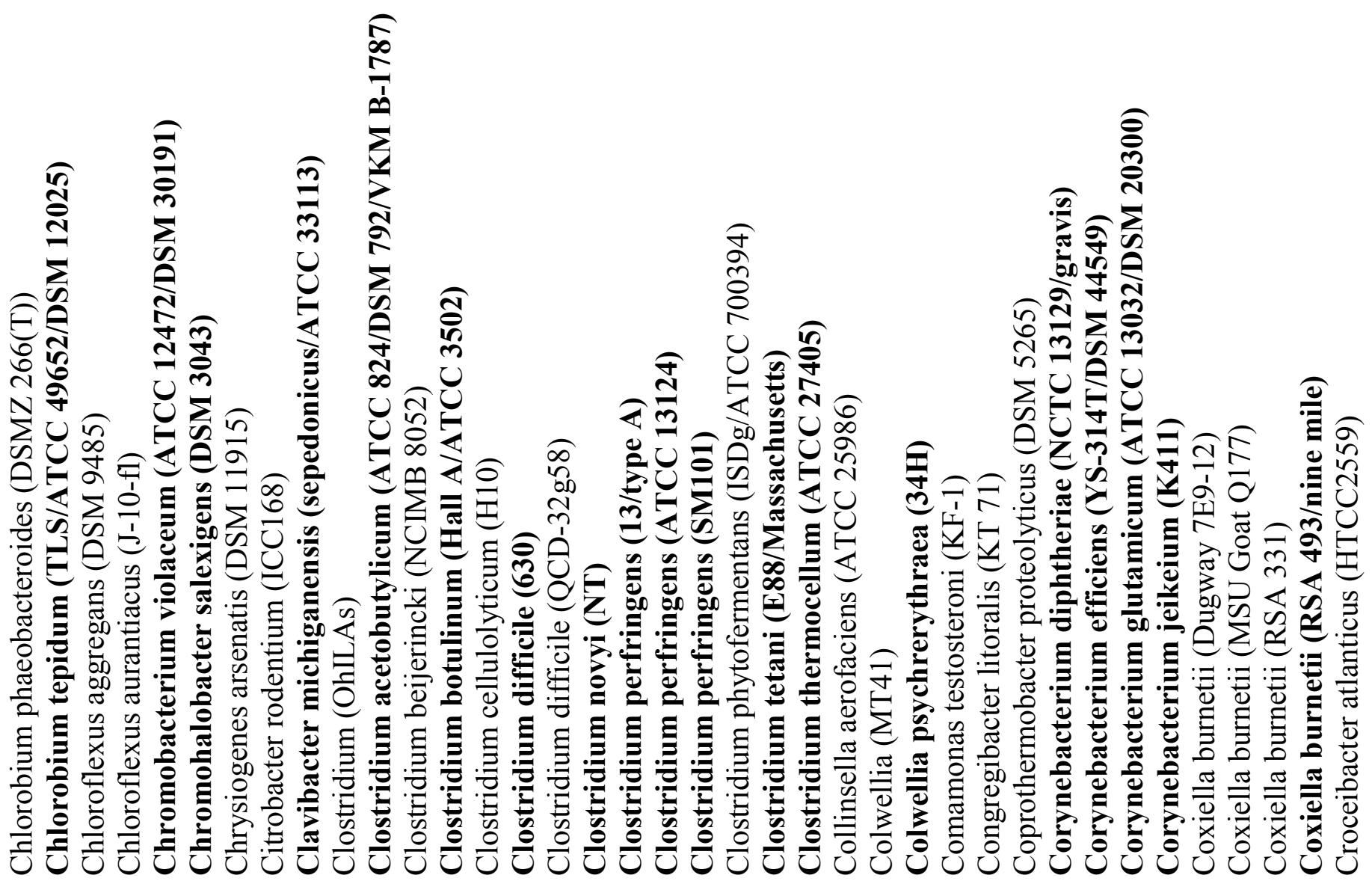




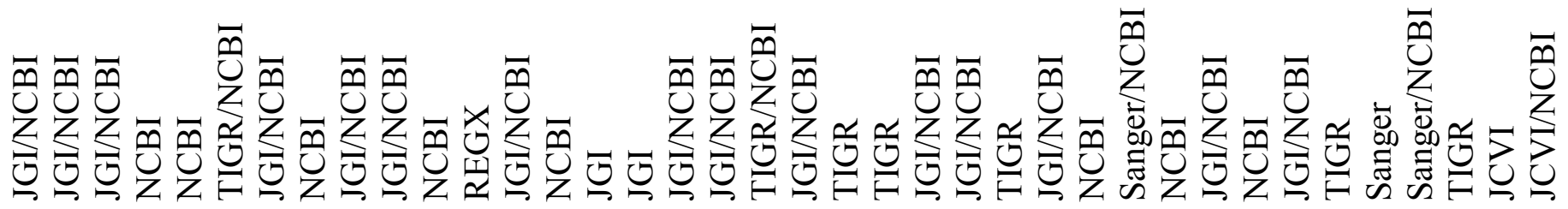

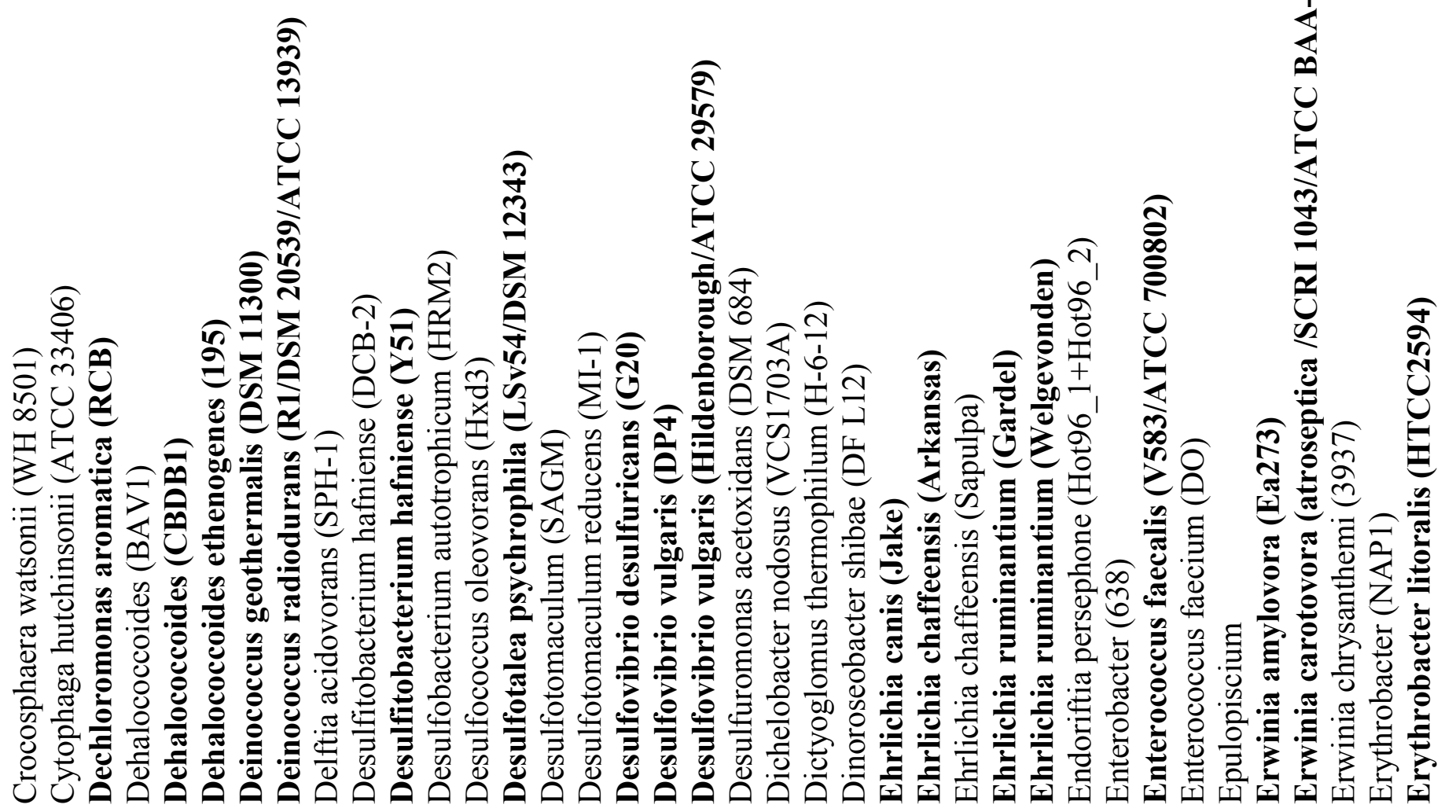




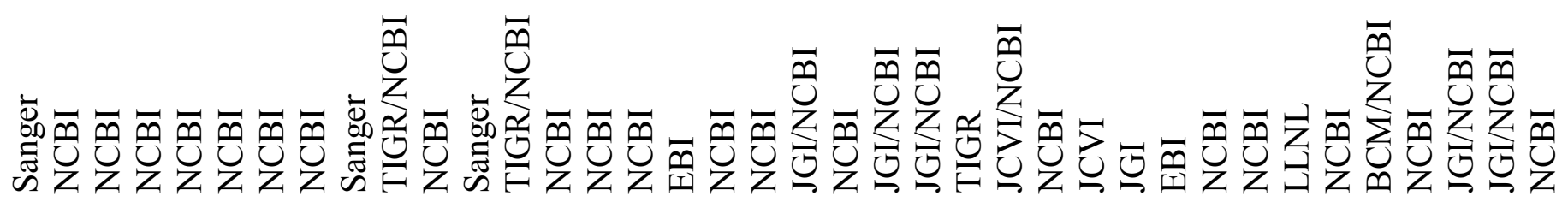

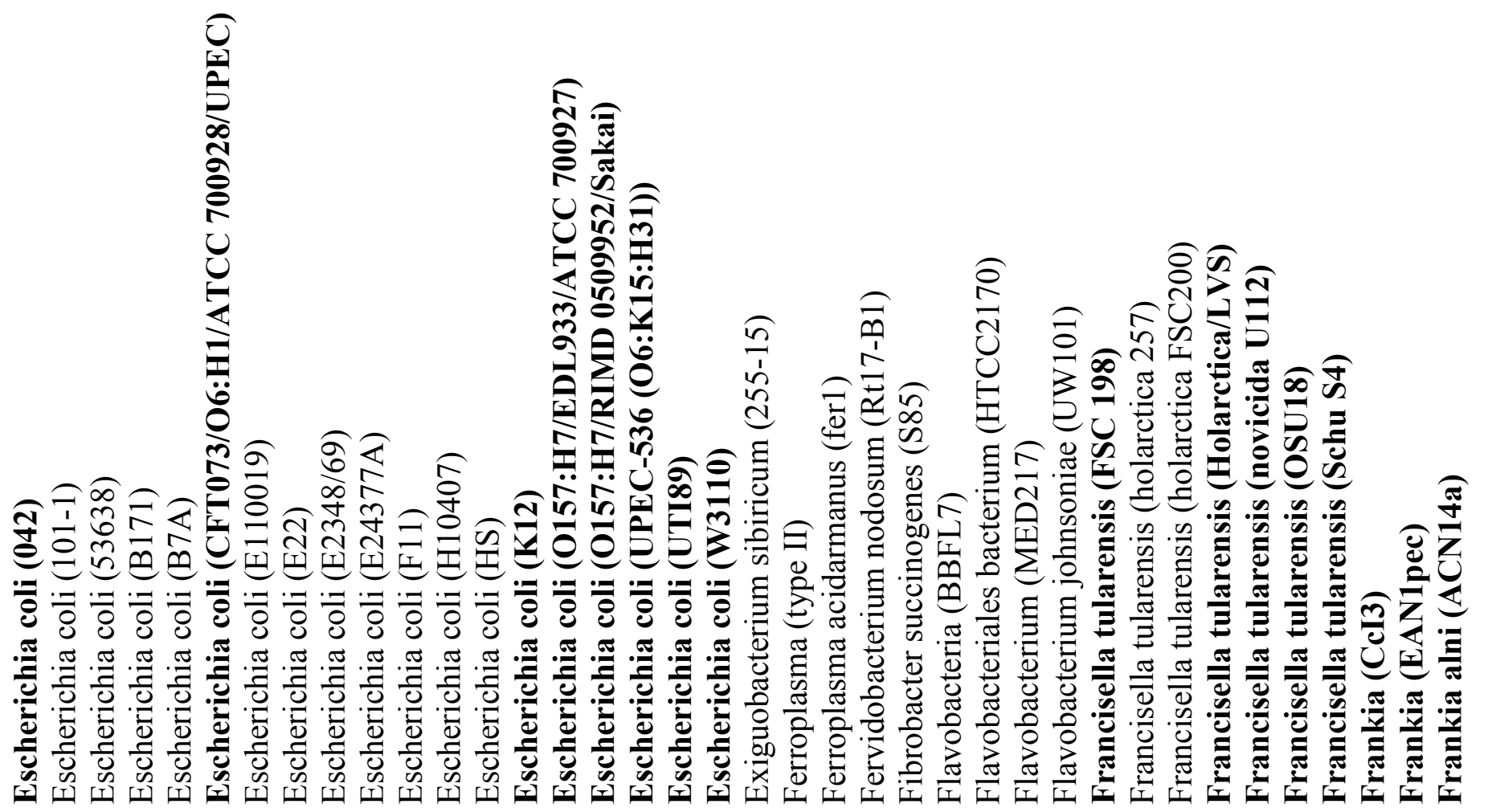




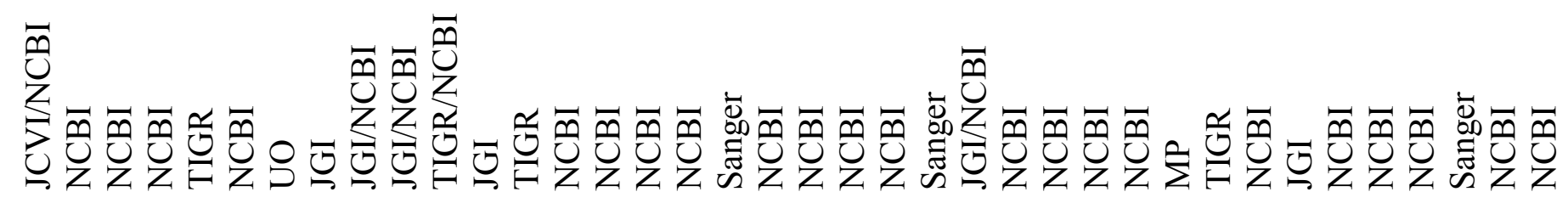

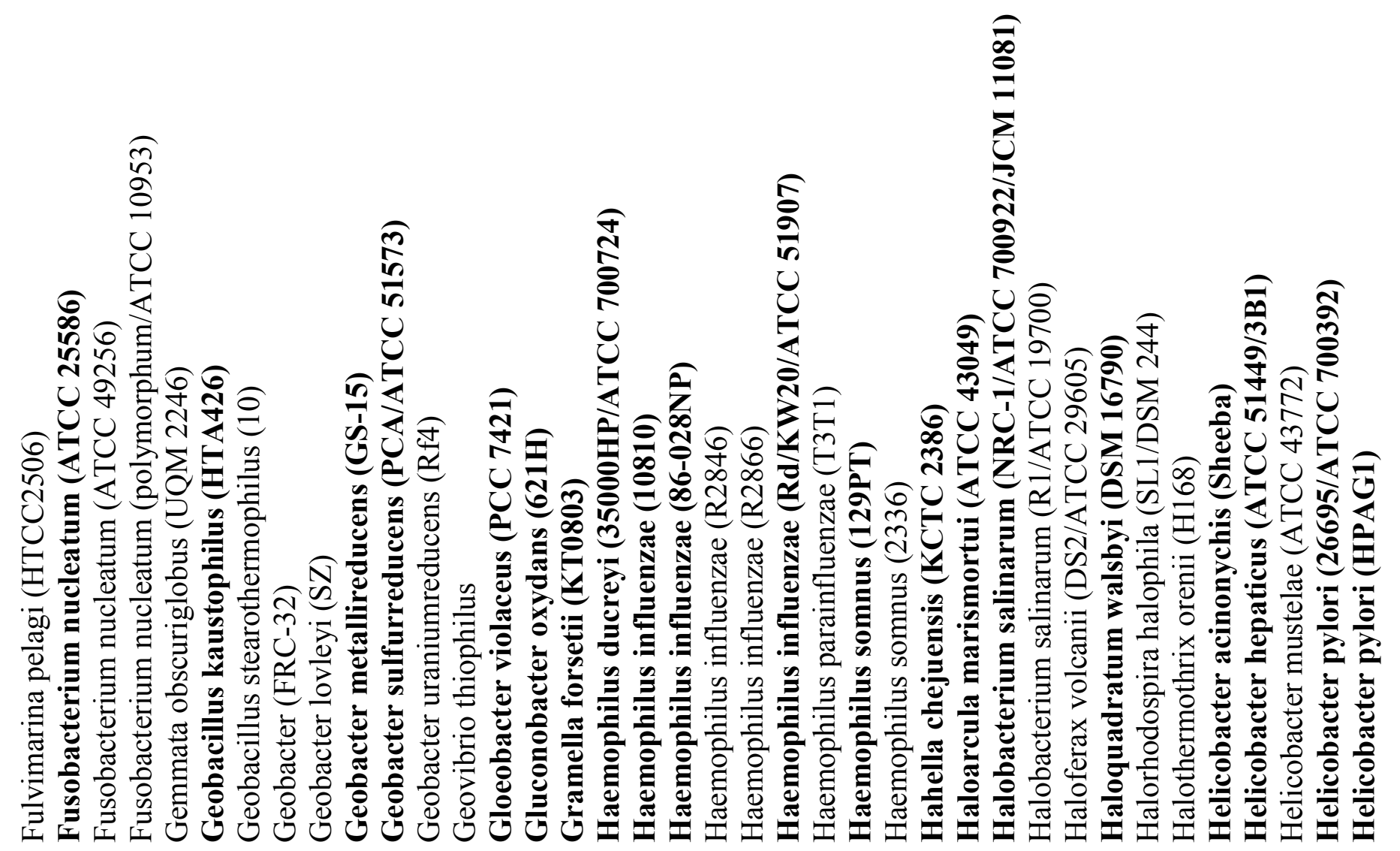




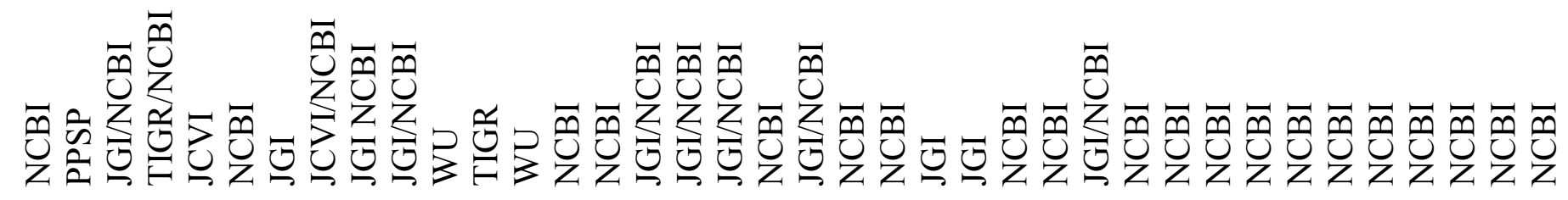

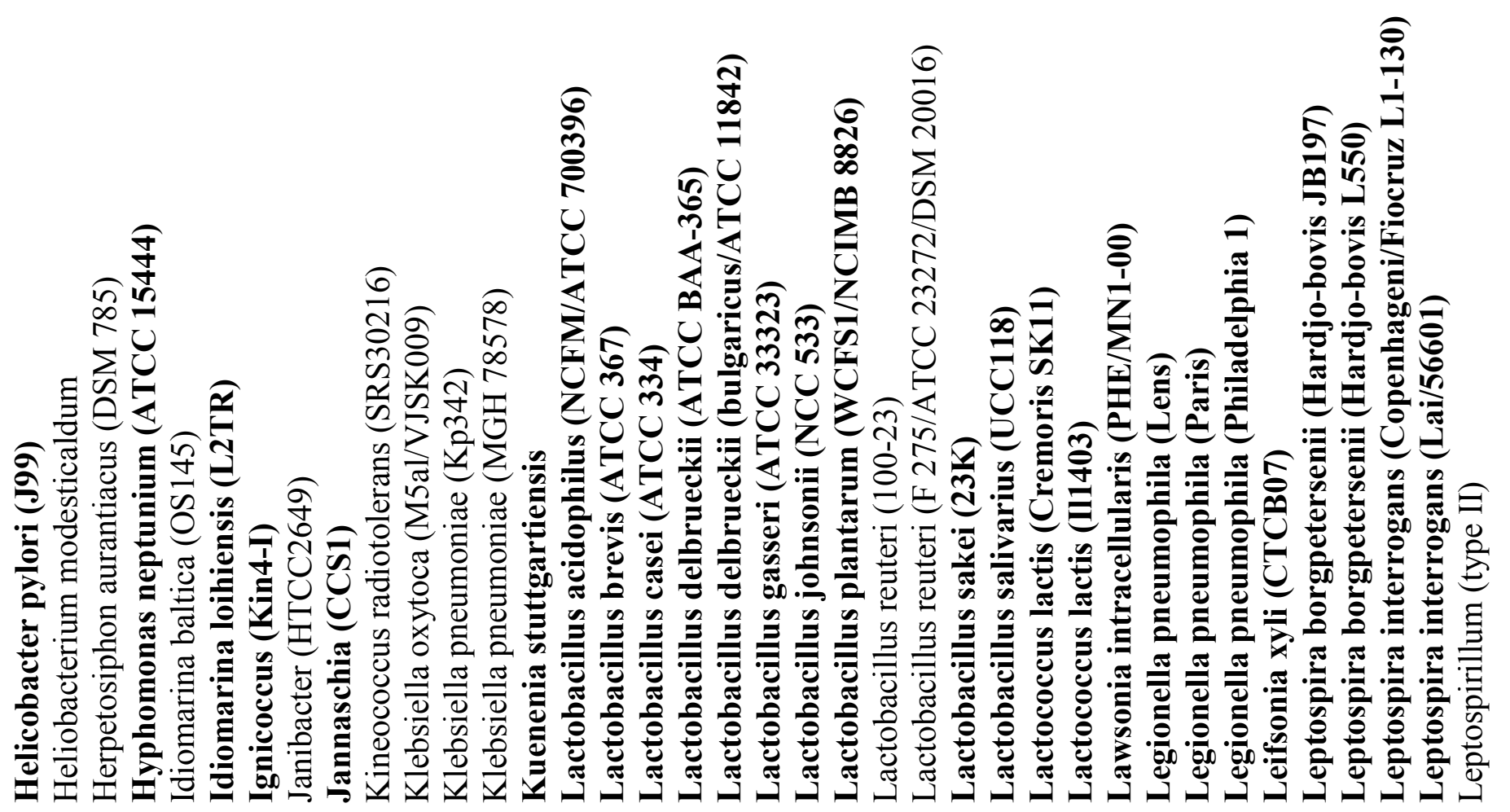




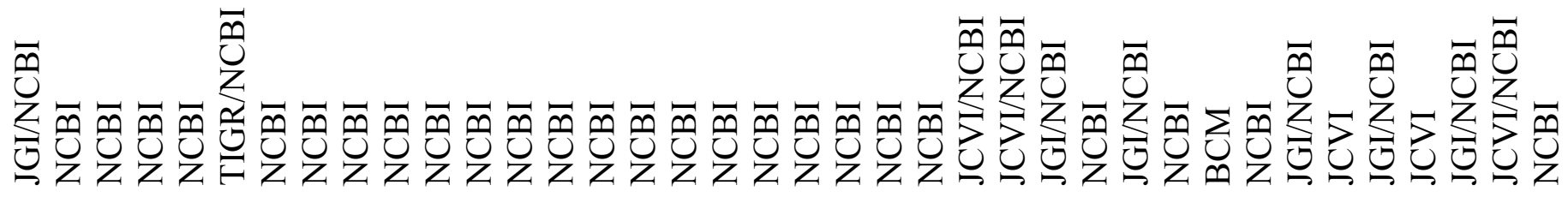

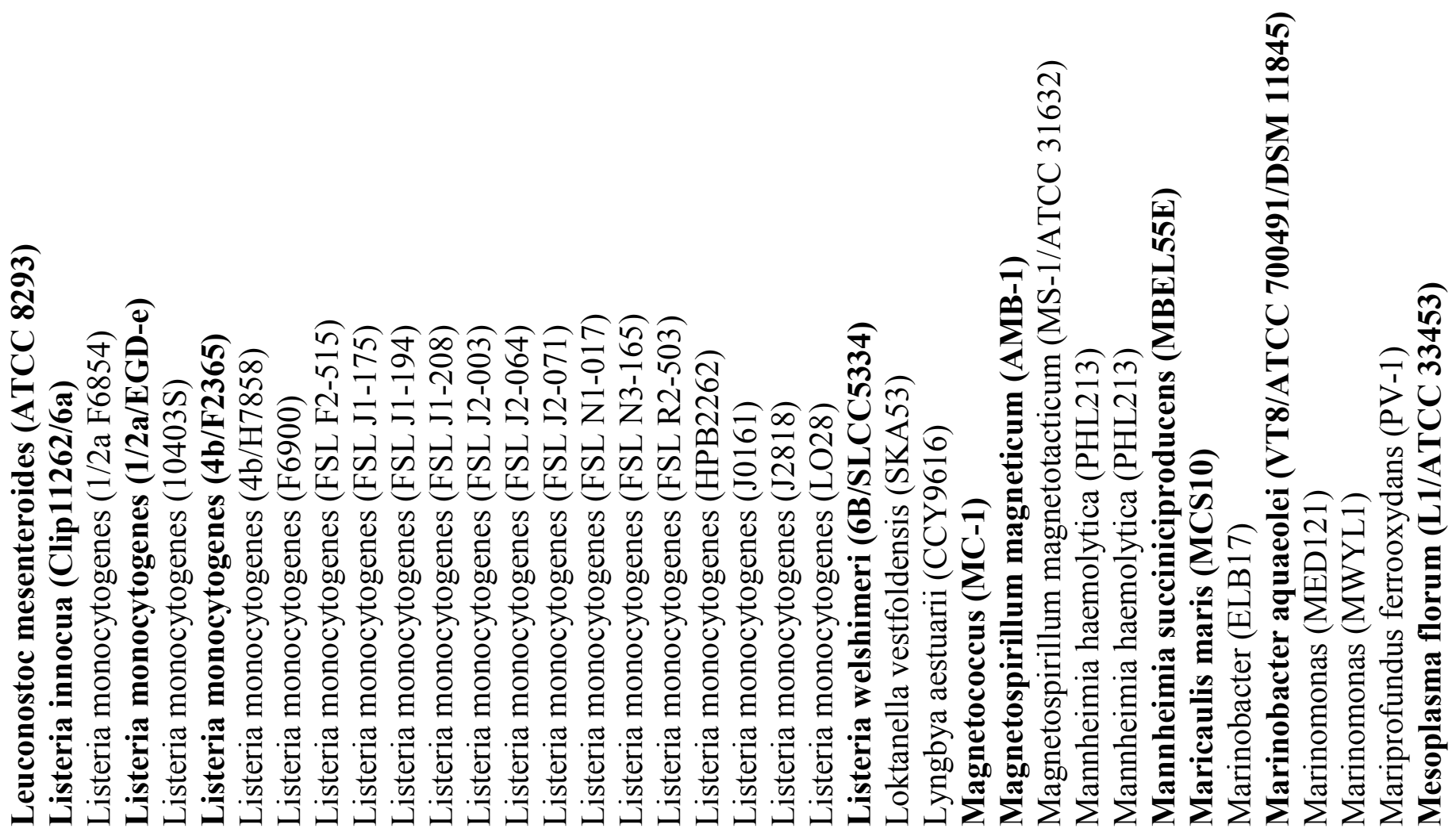




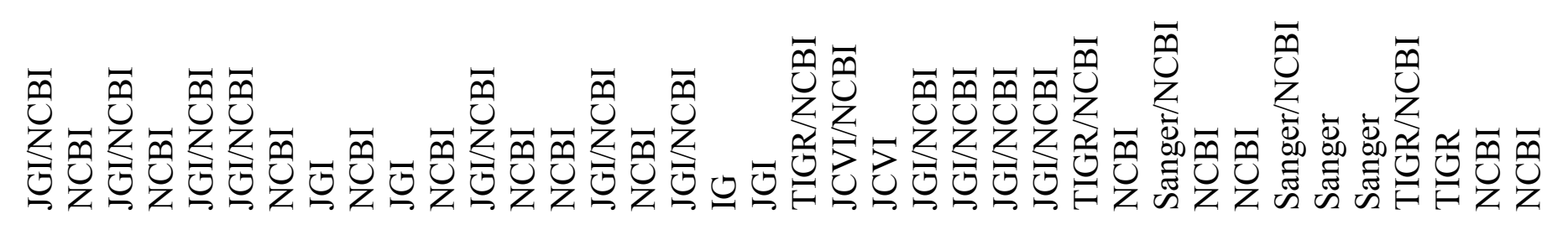

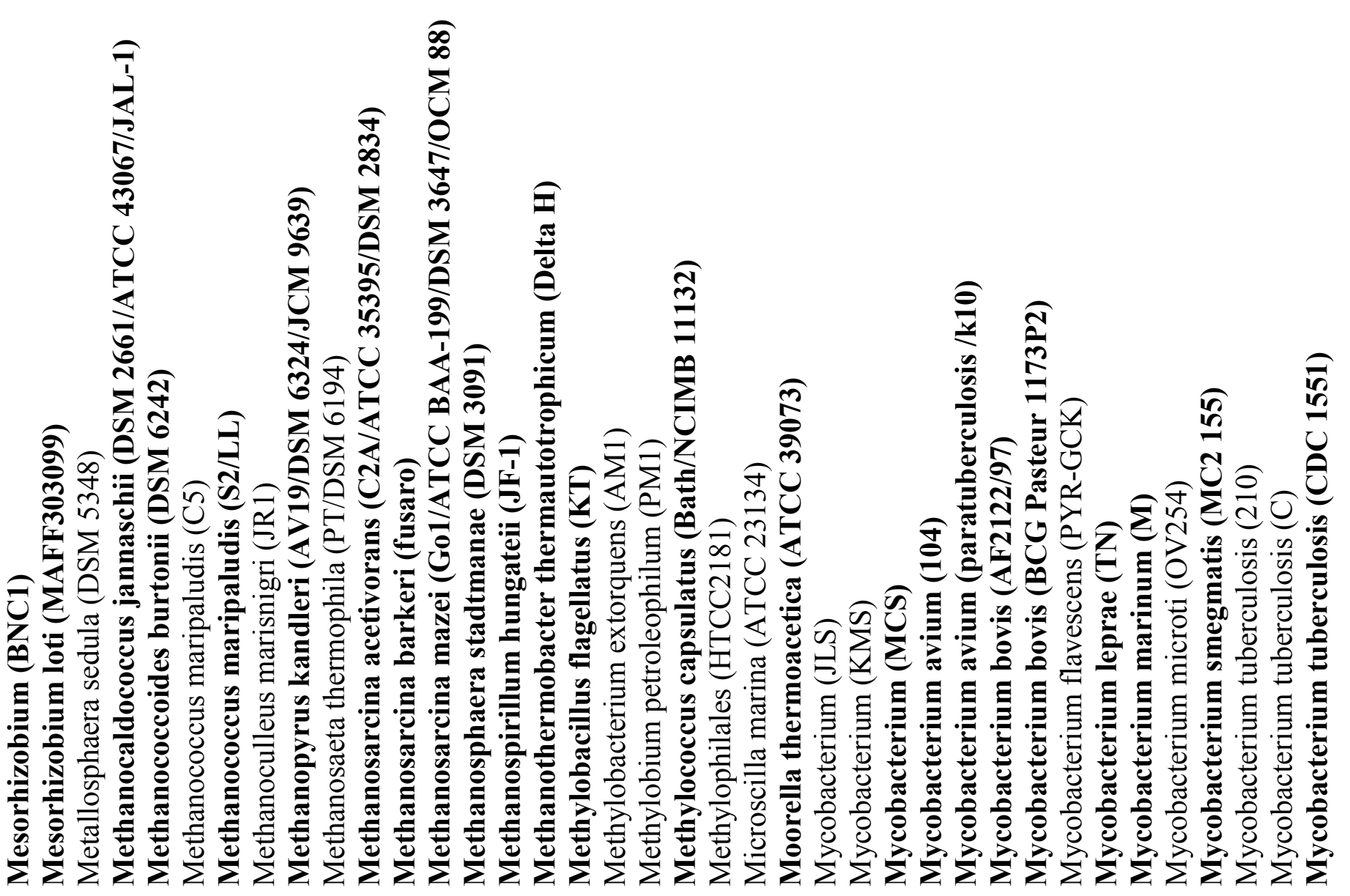




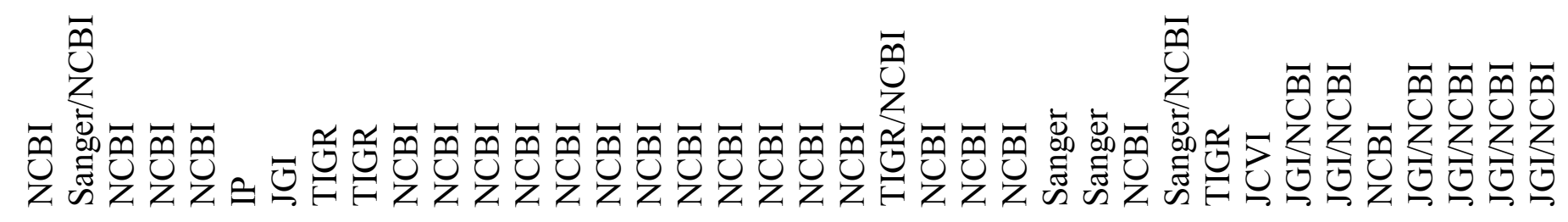

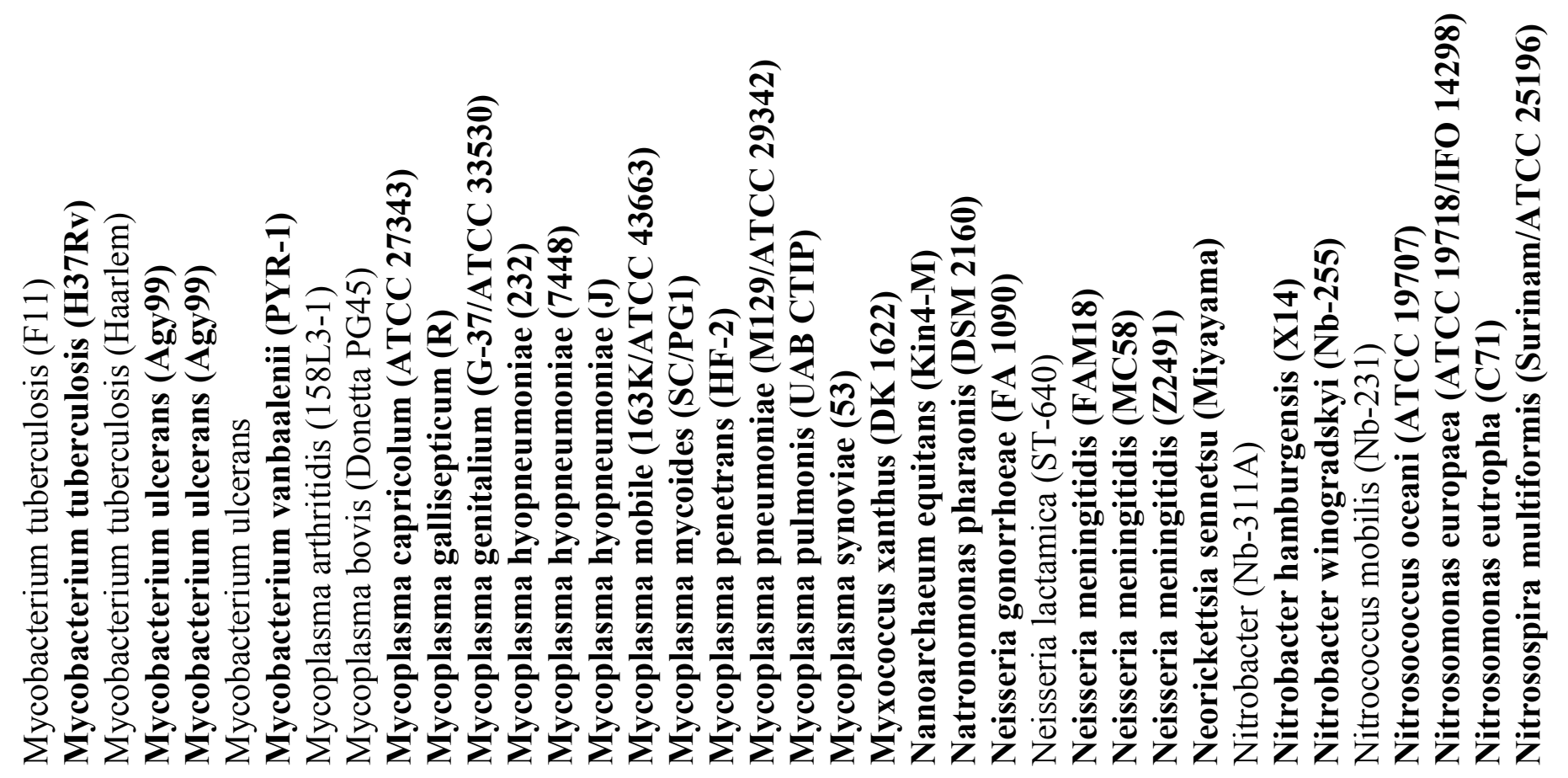




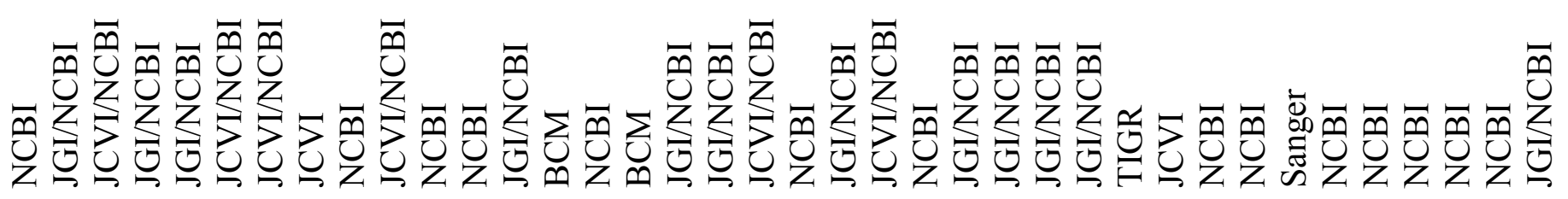

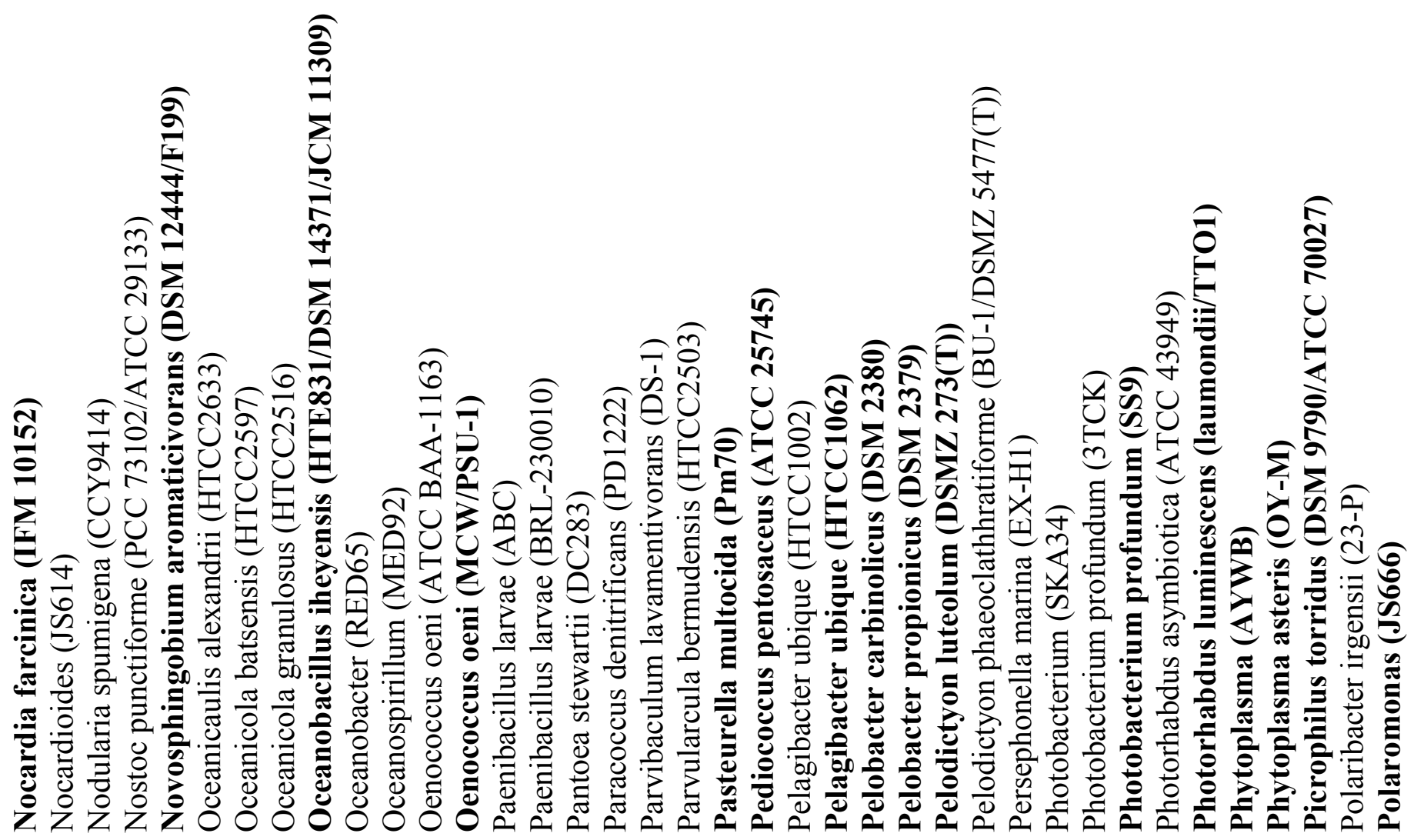




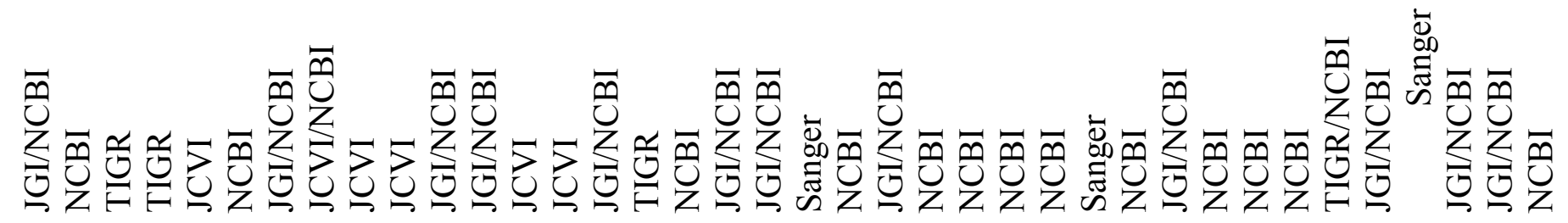

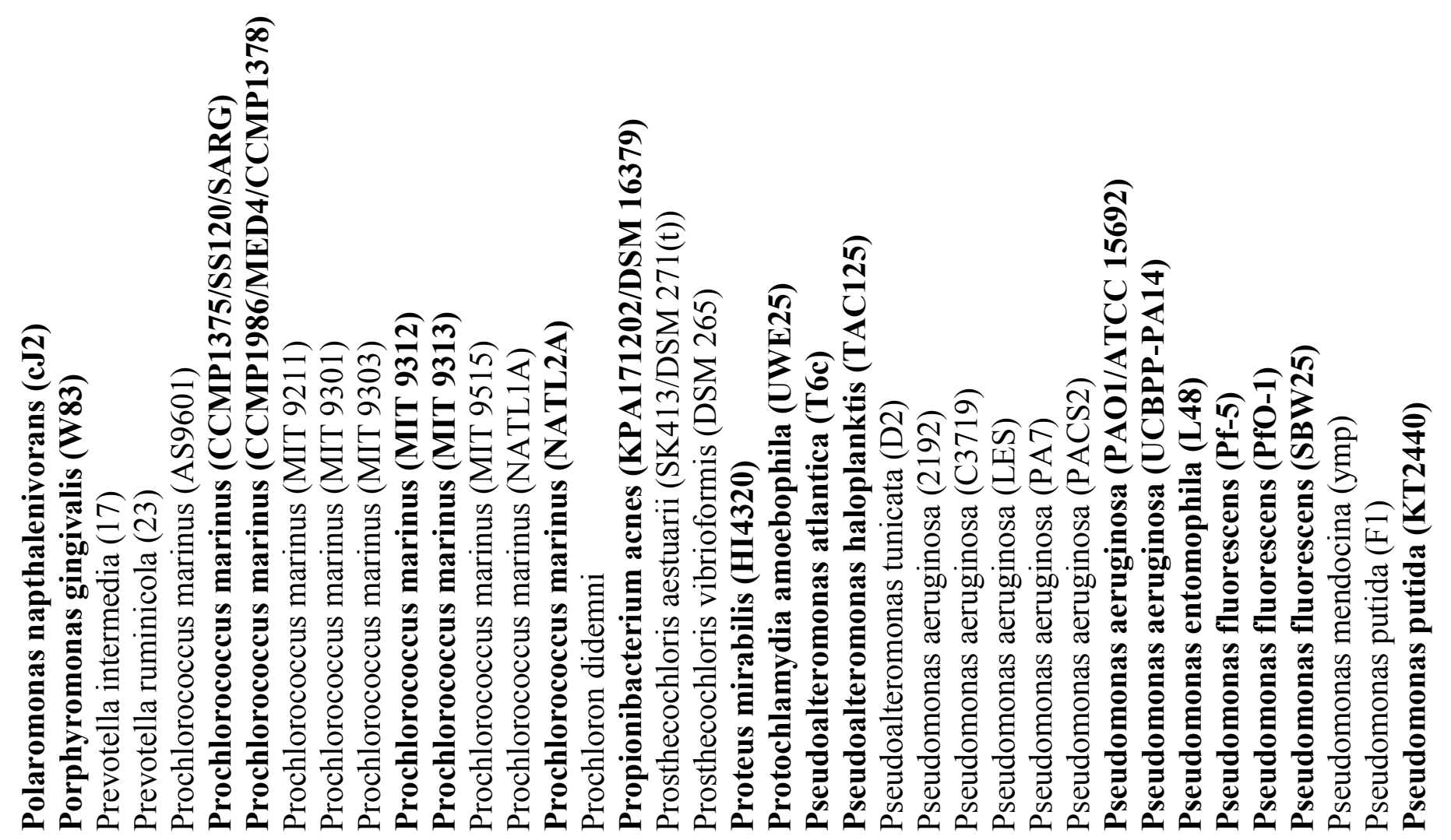




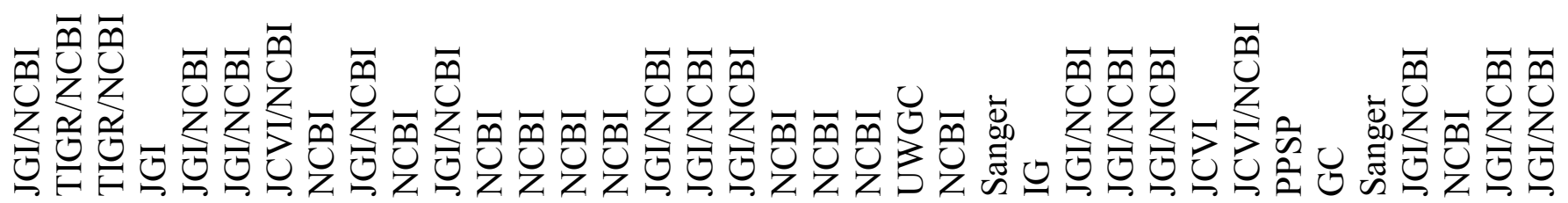

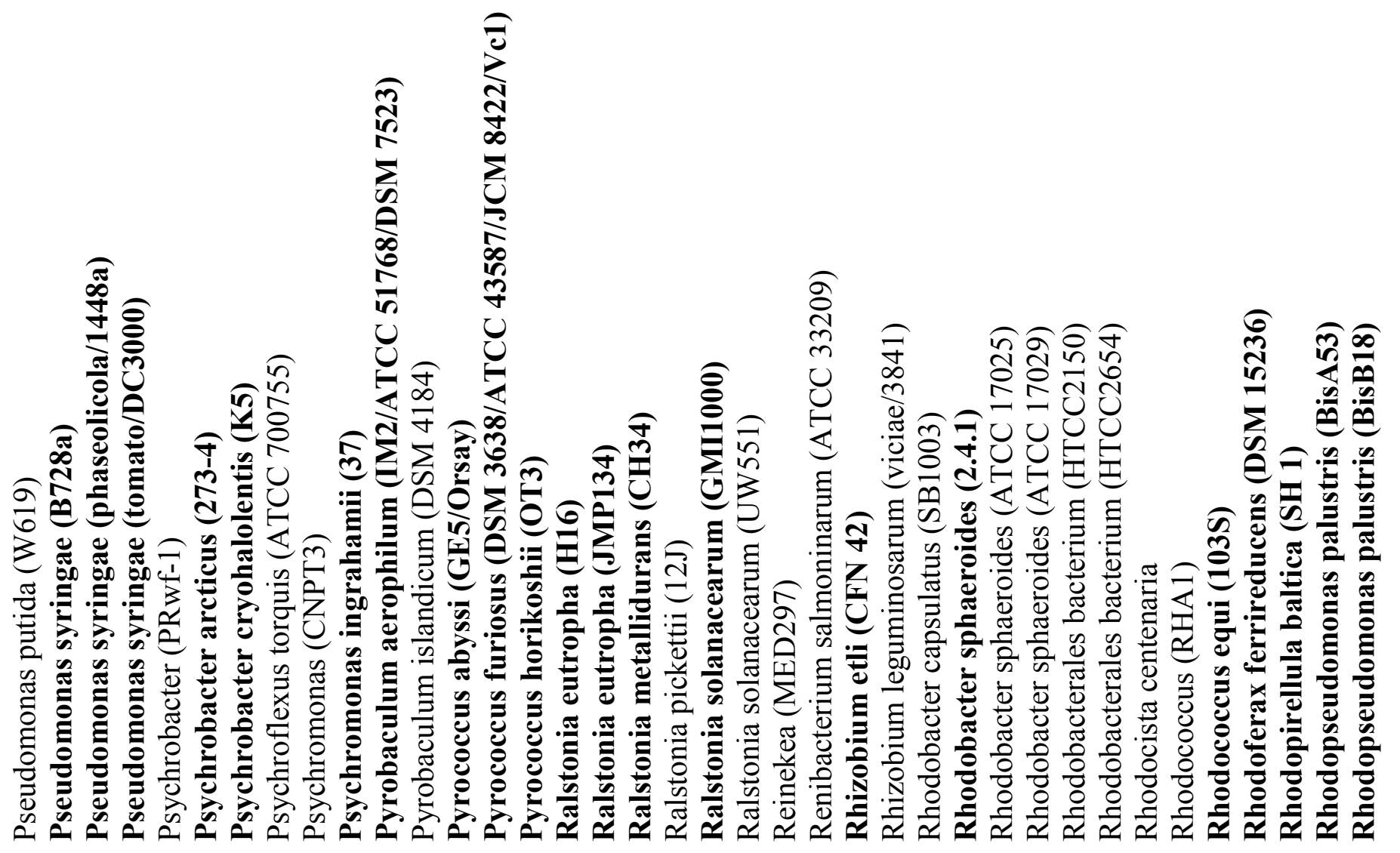




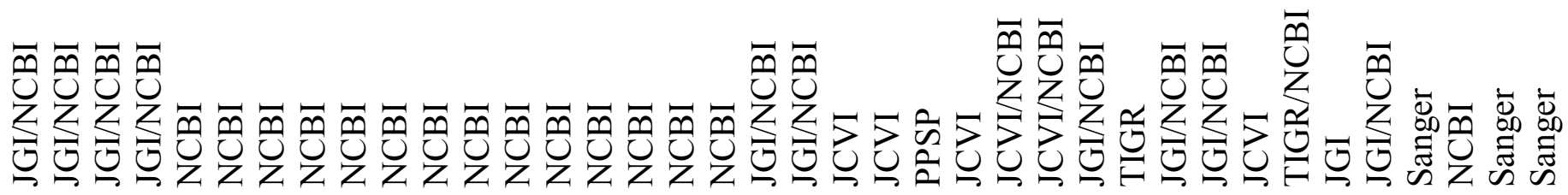

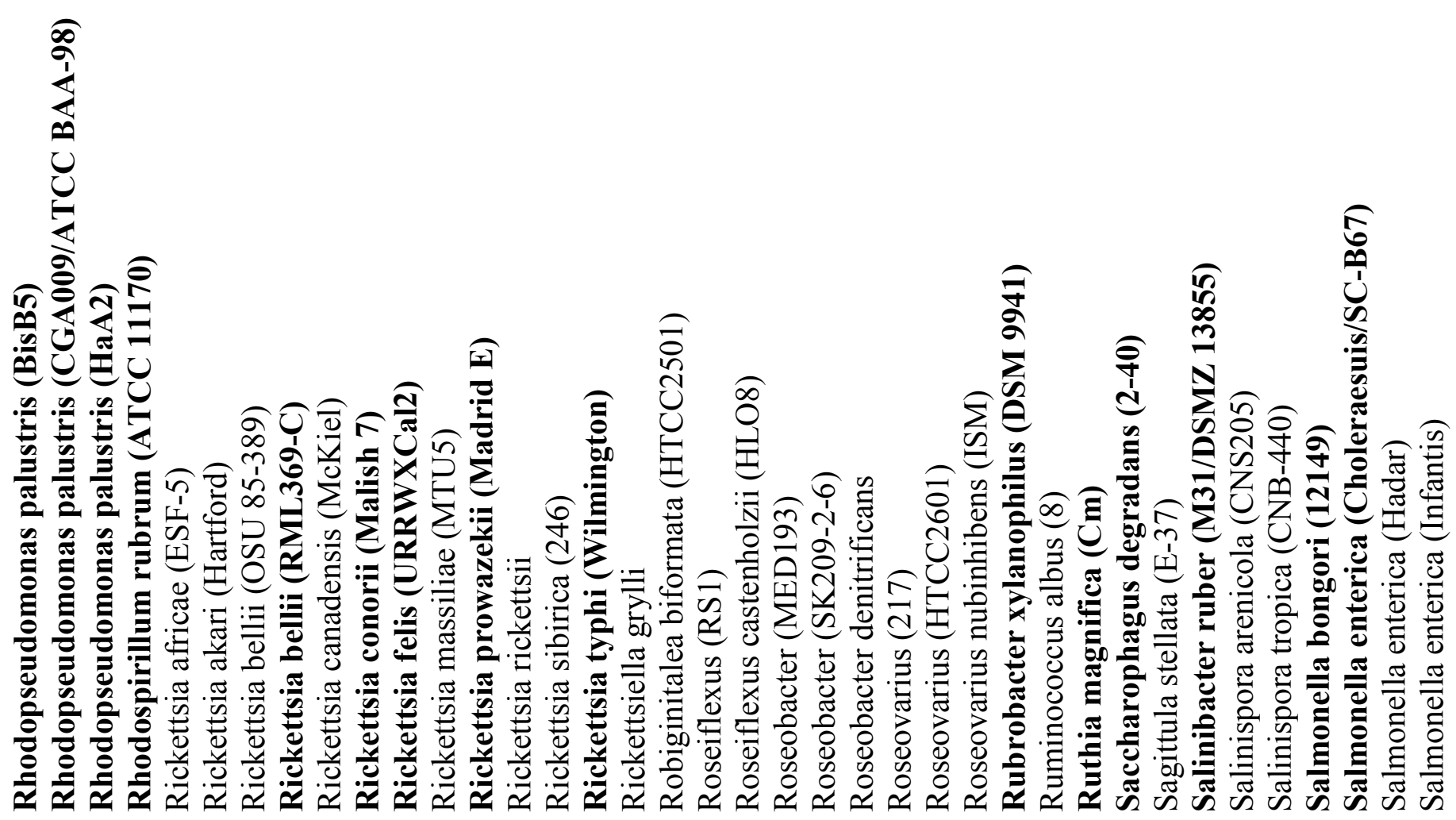


$\overline{0}$

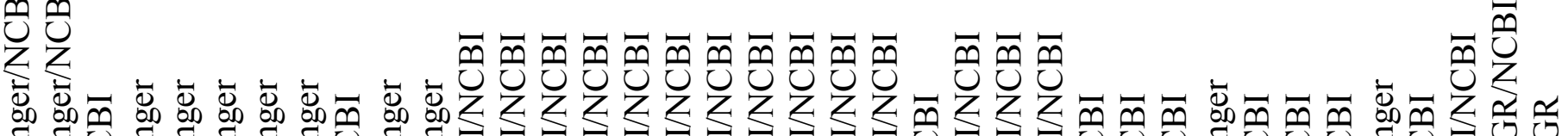

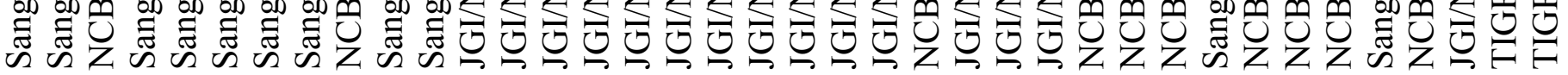

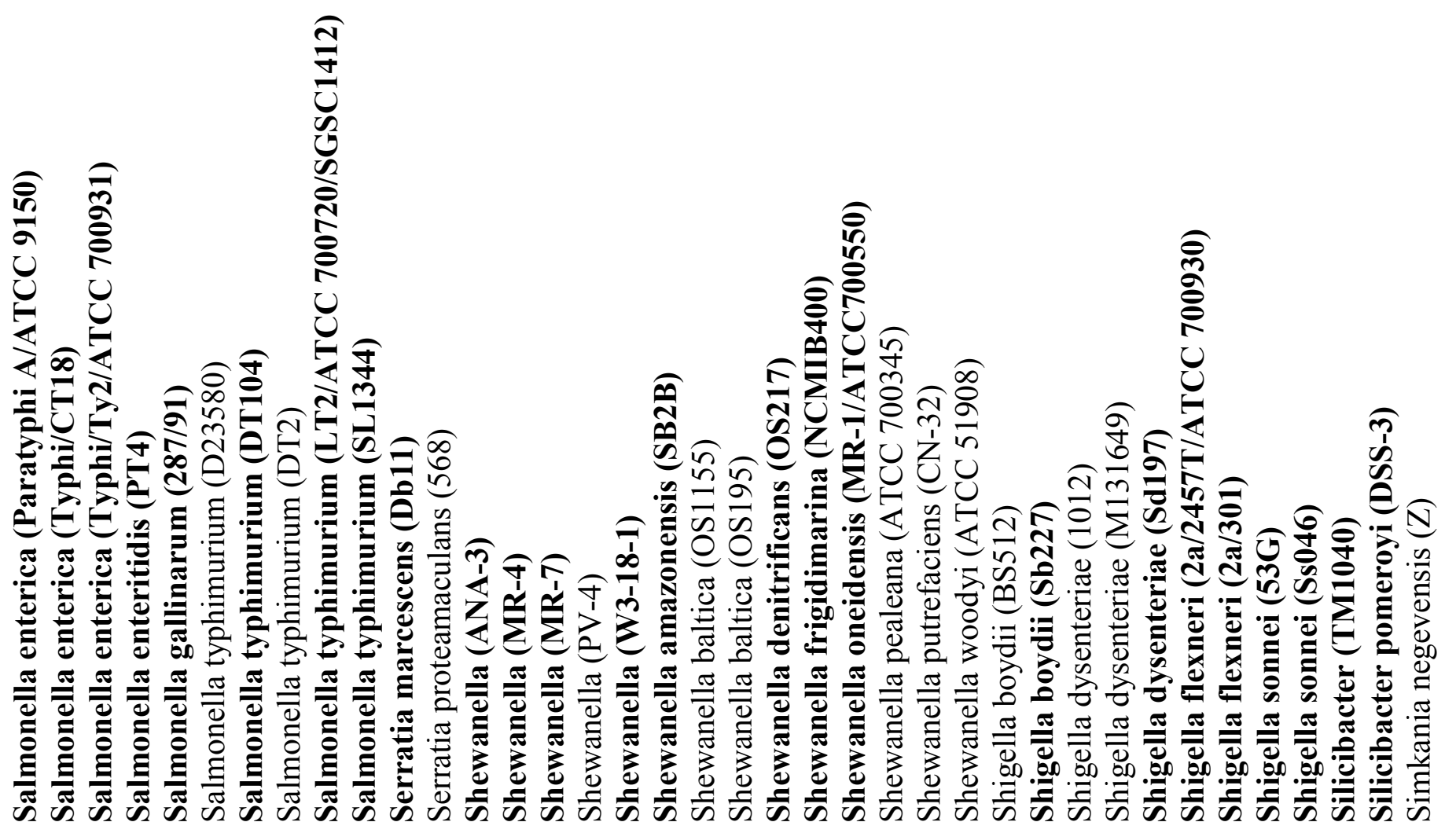




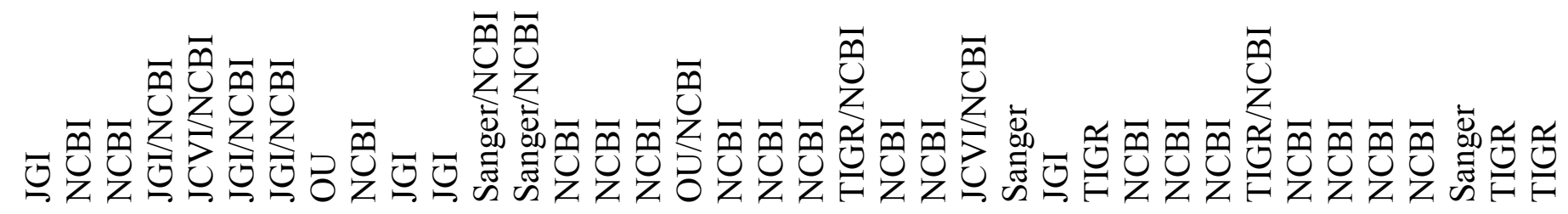

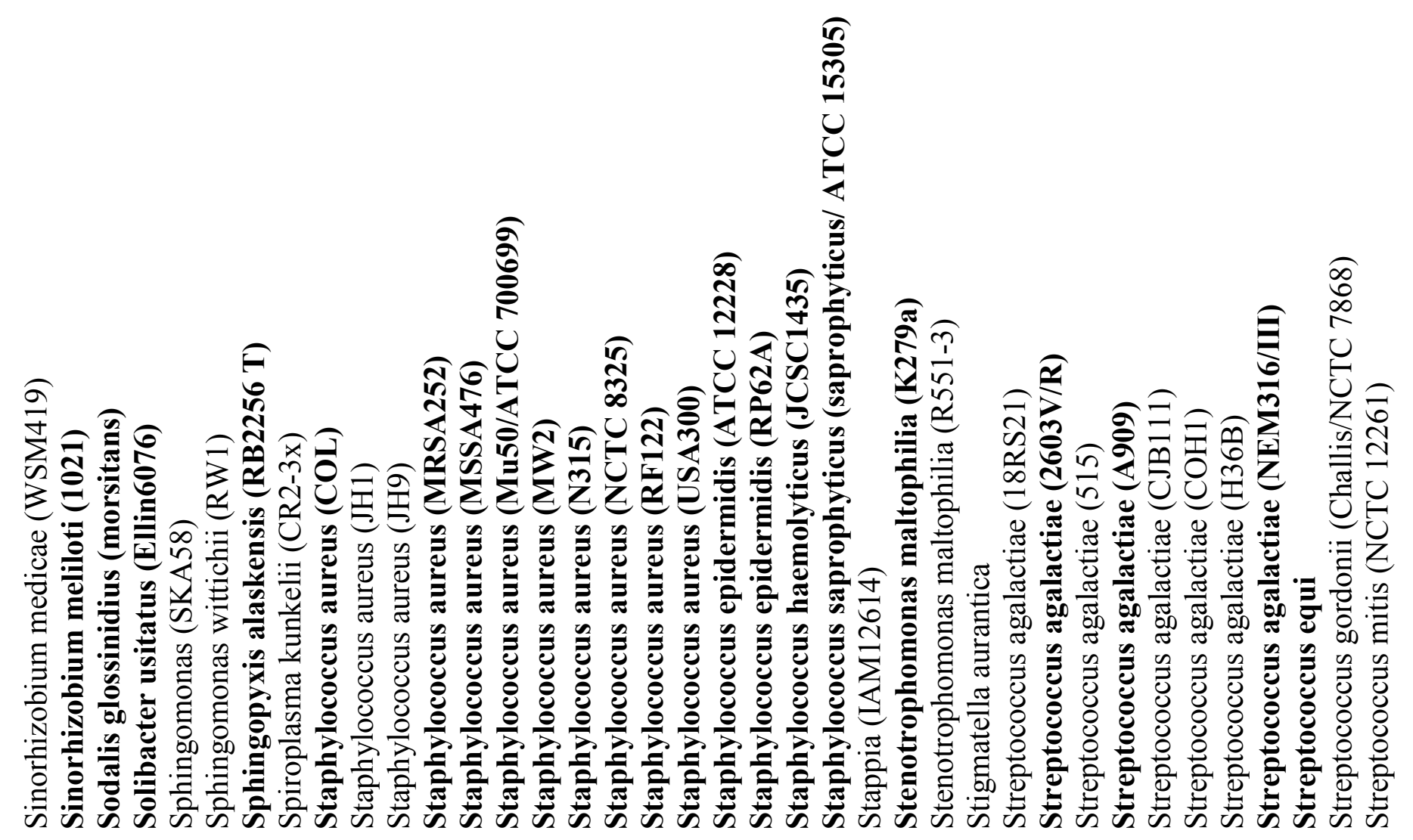




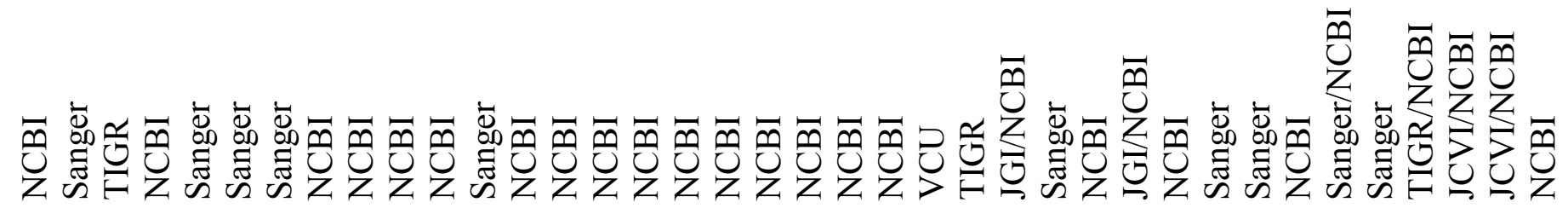

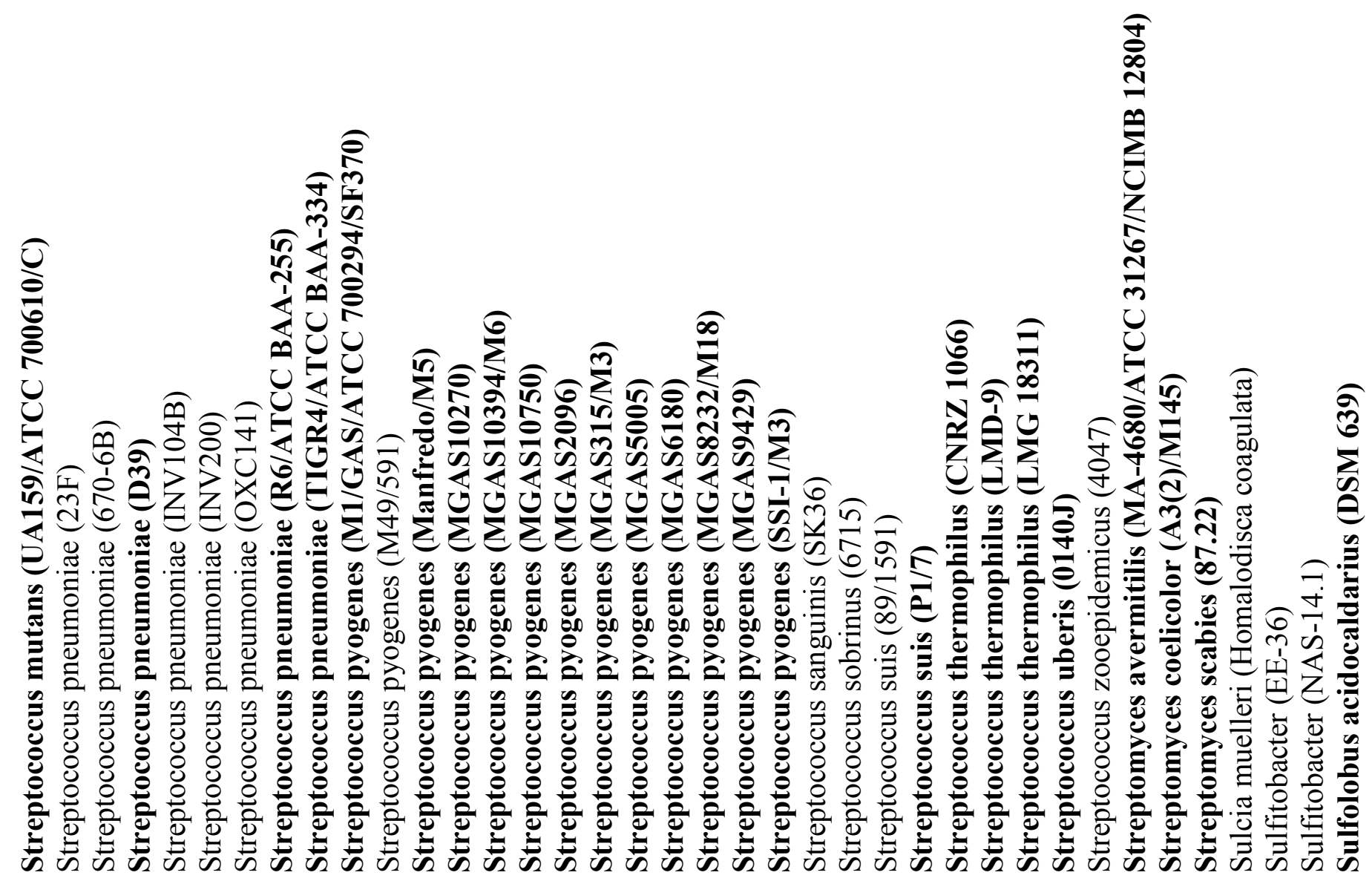




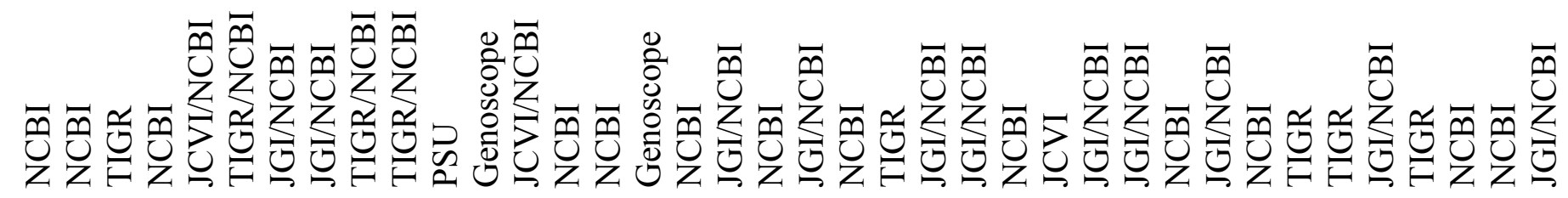

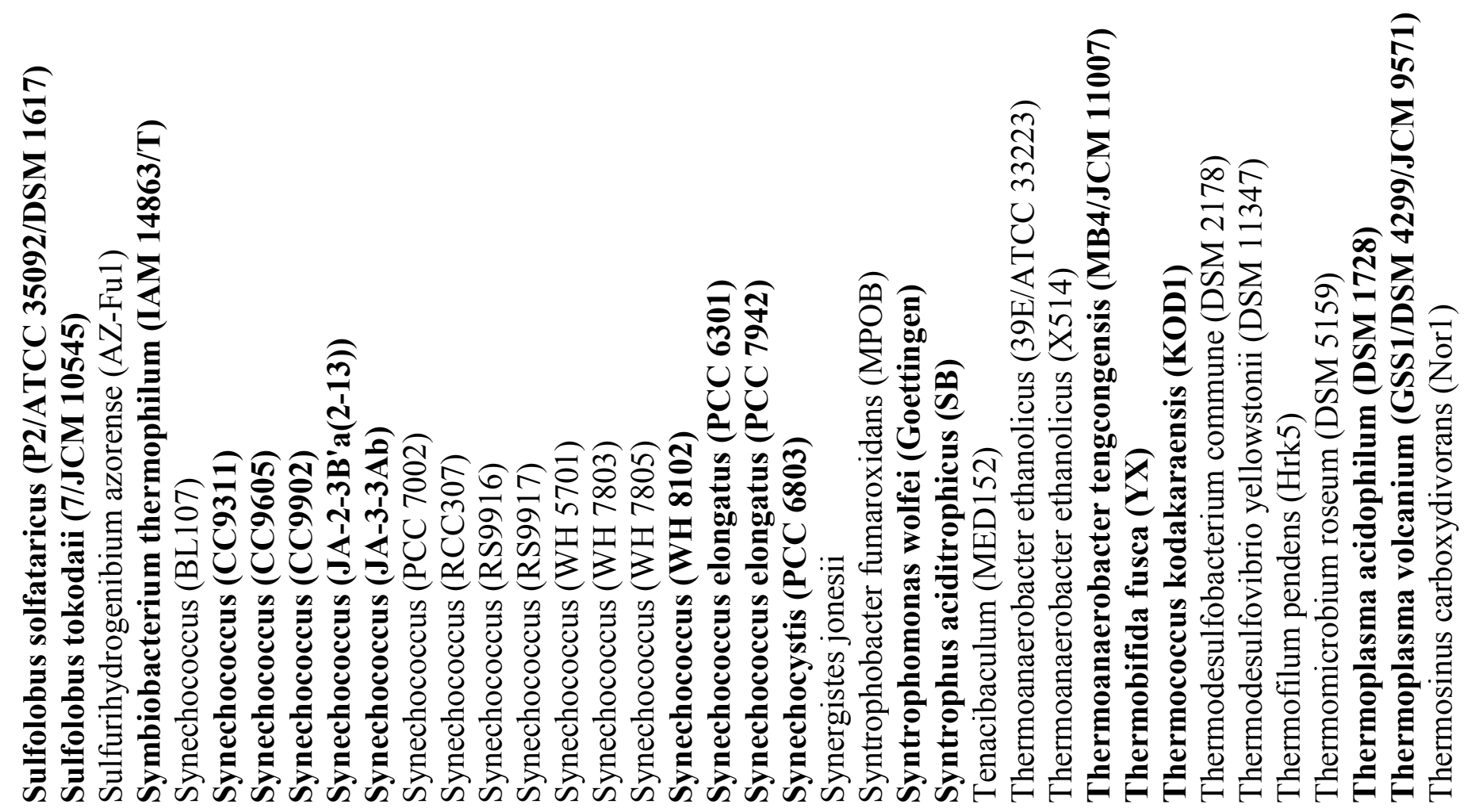




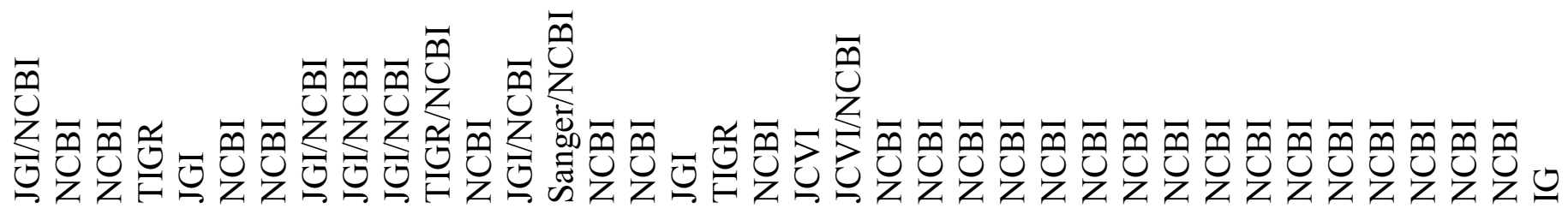

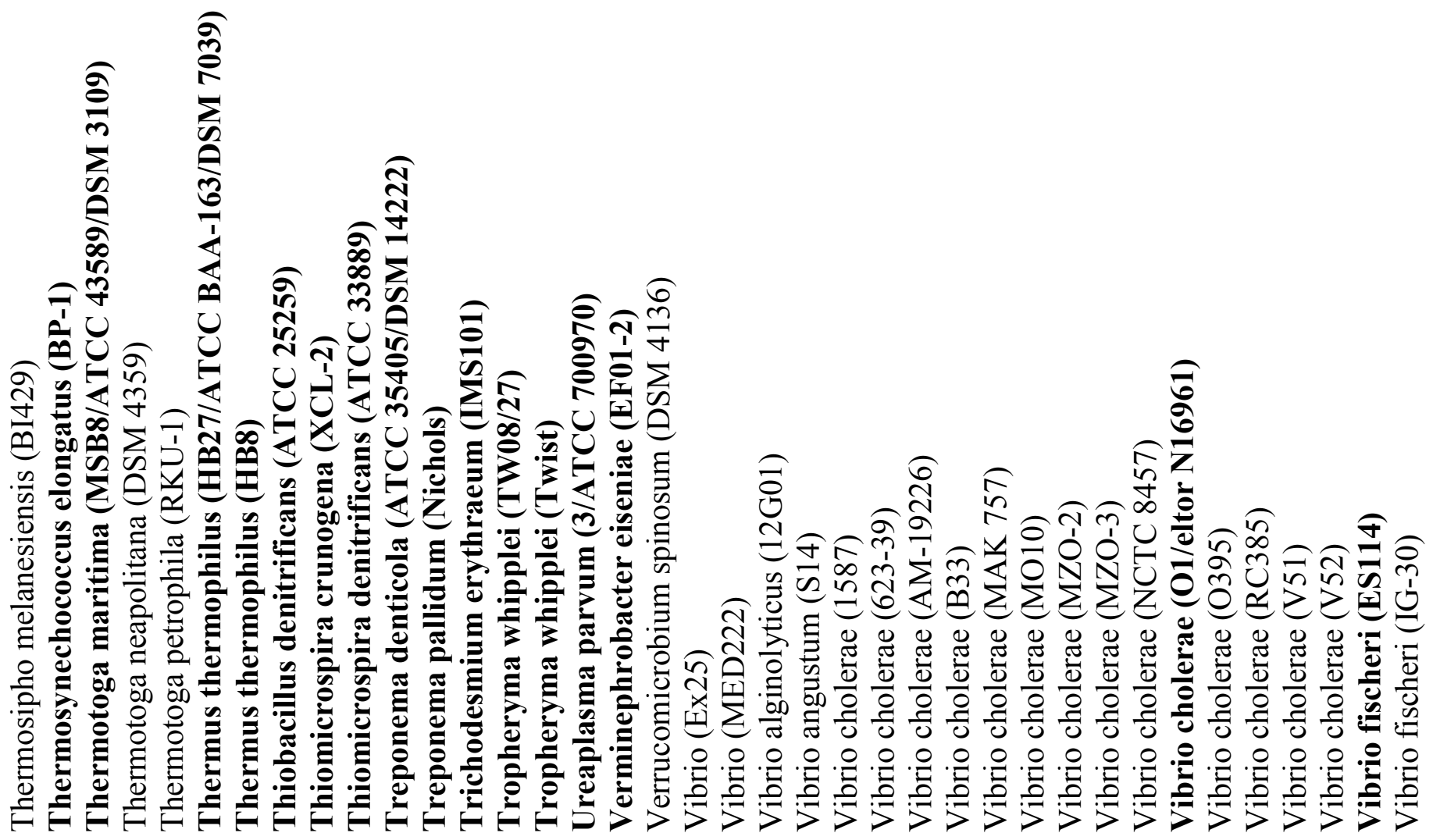




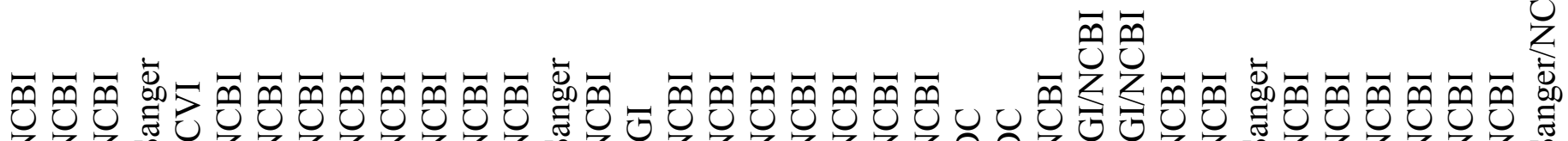

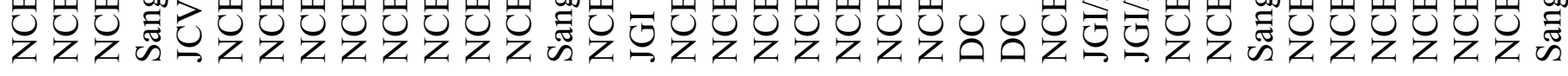

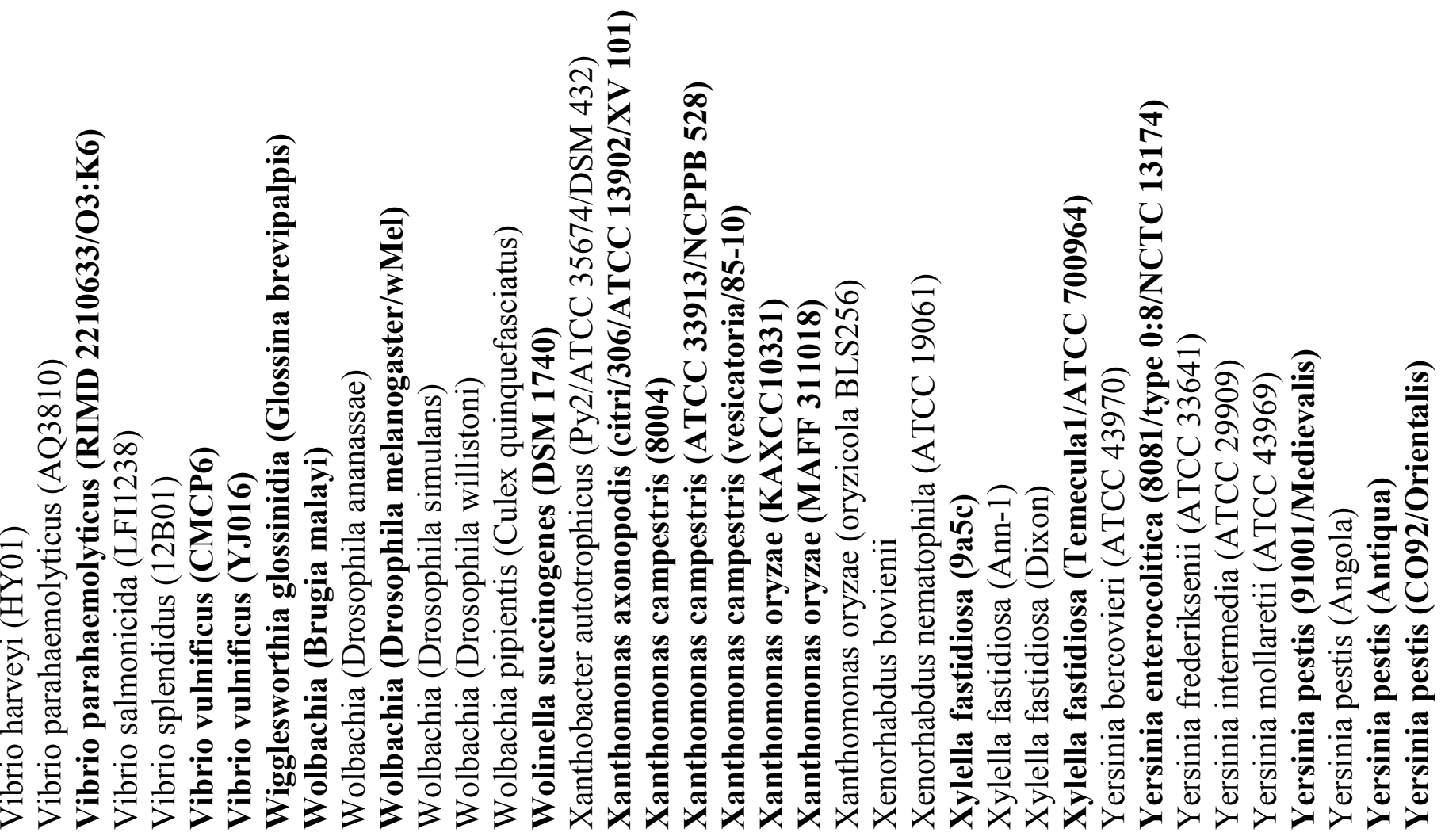




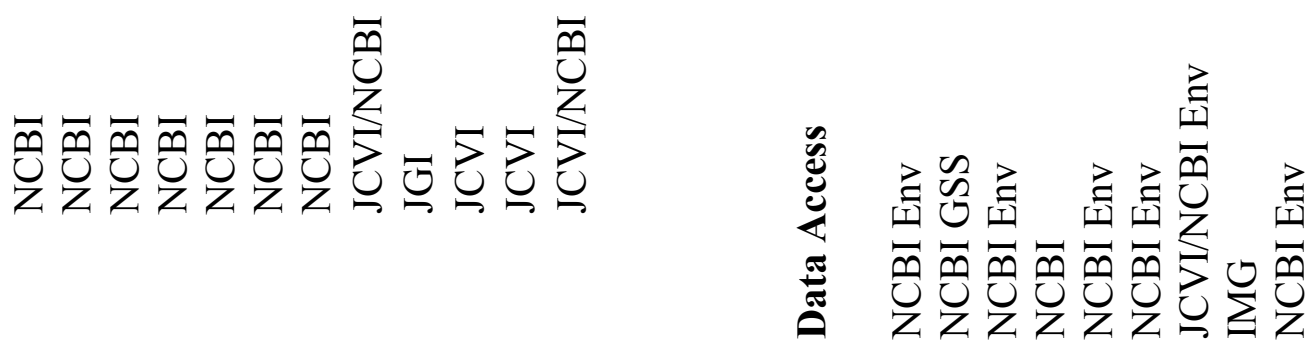

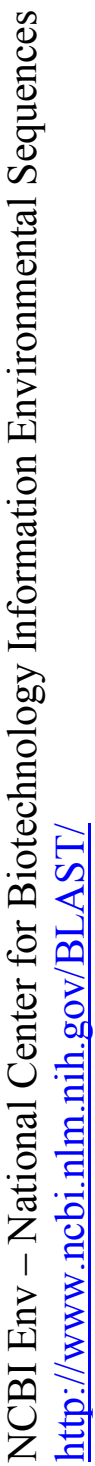



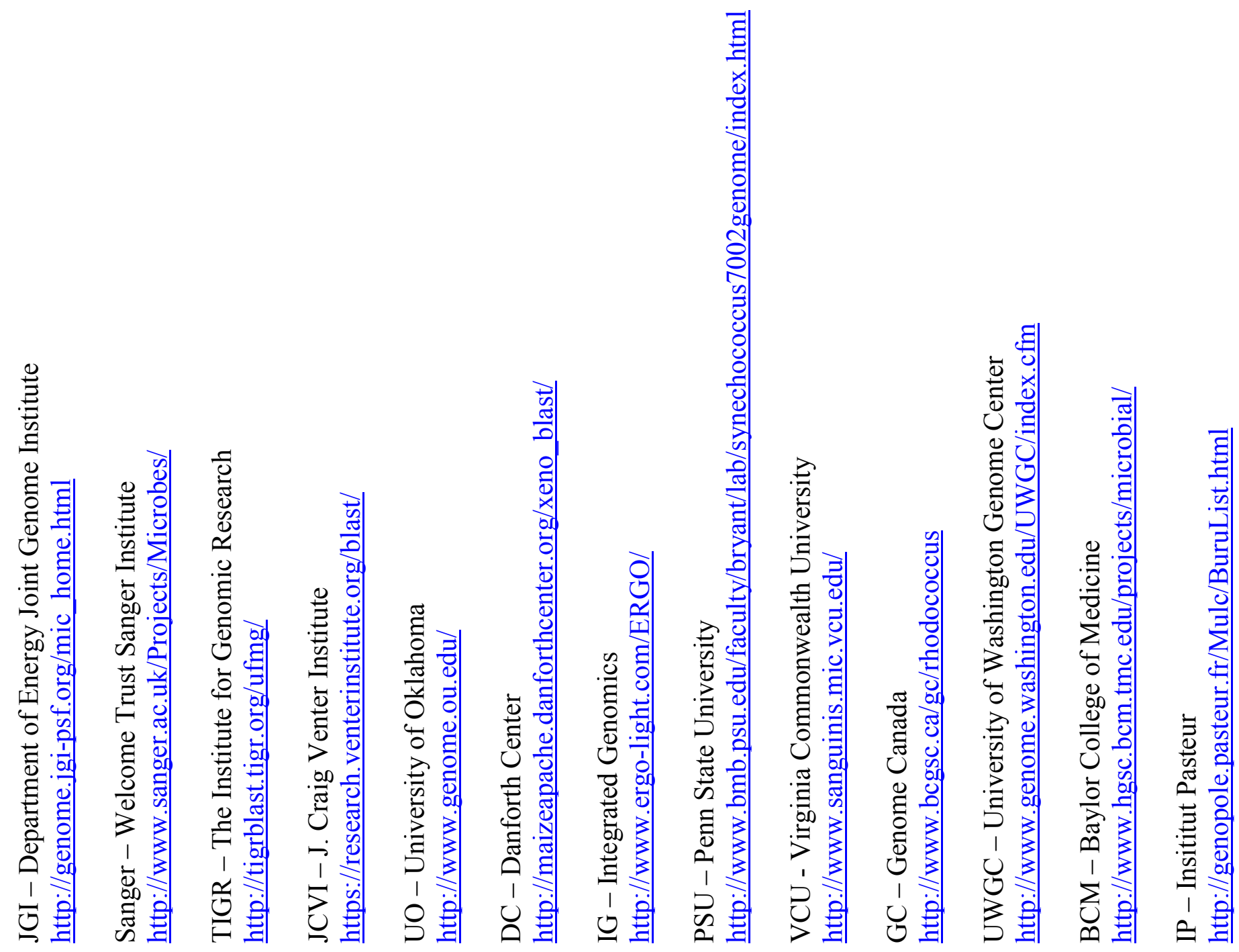


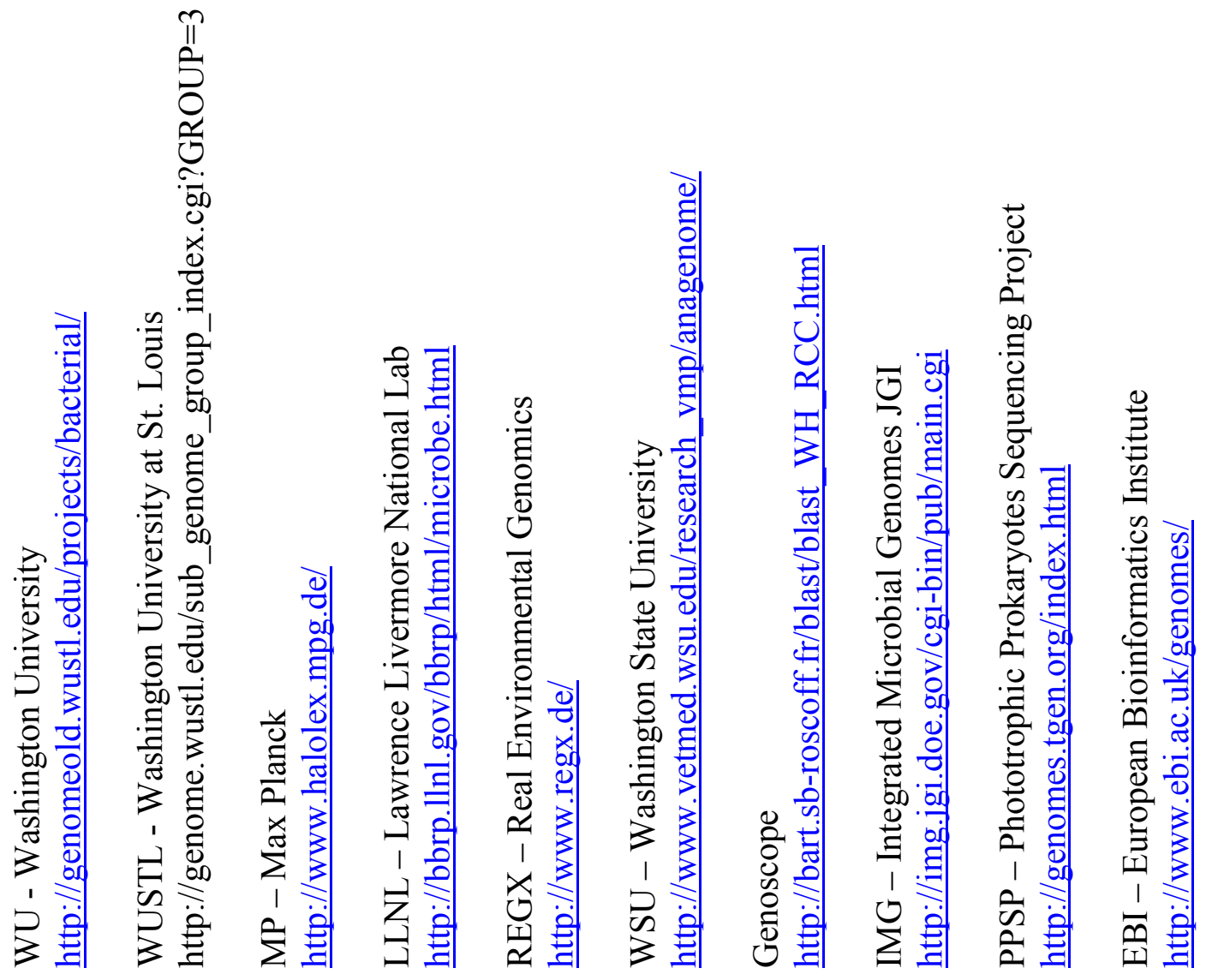




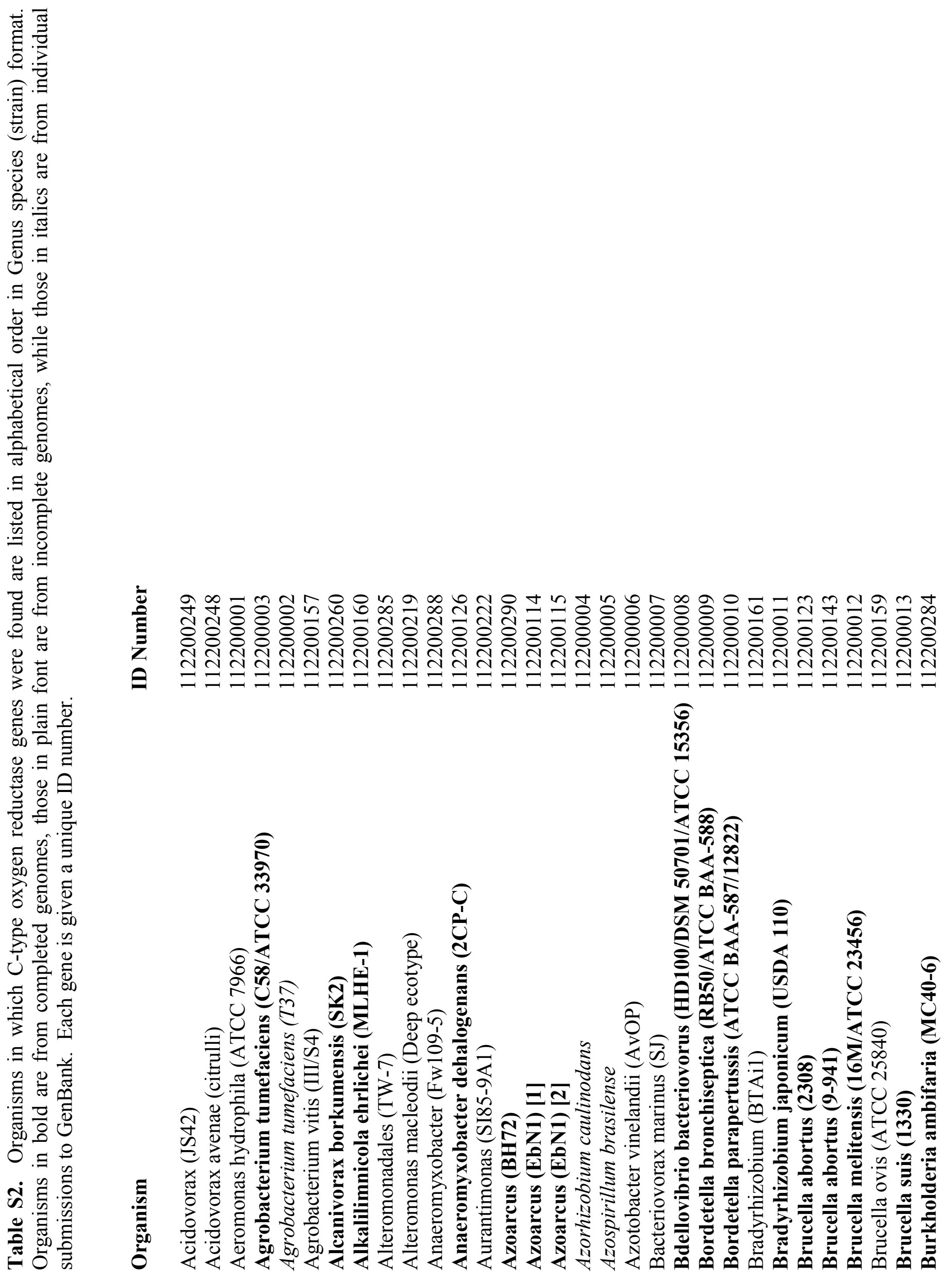




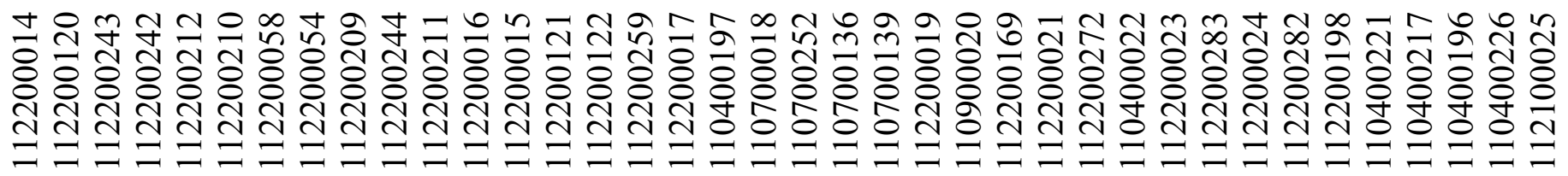

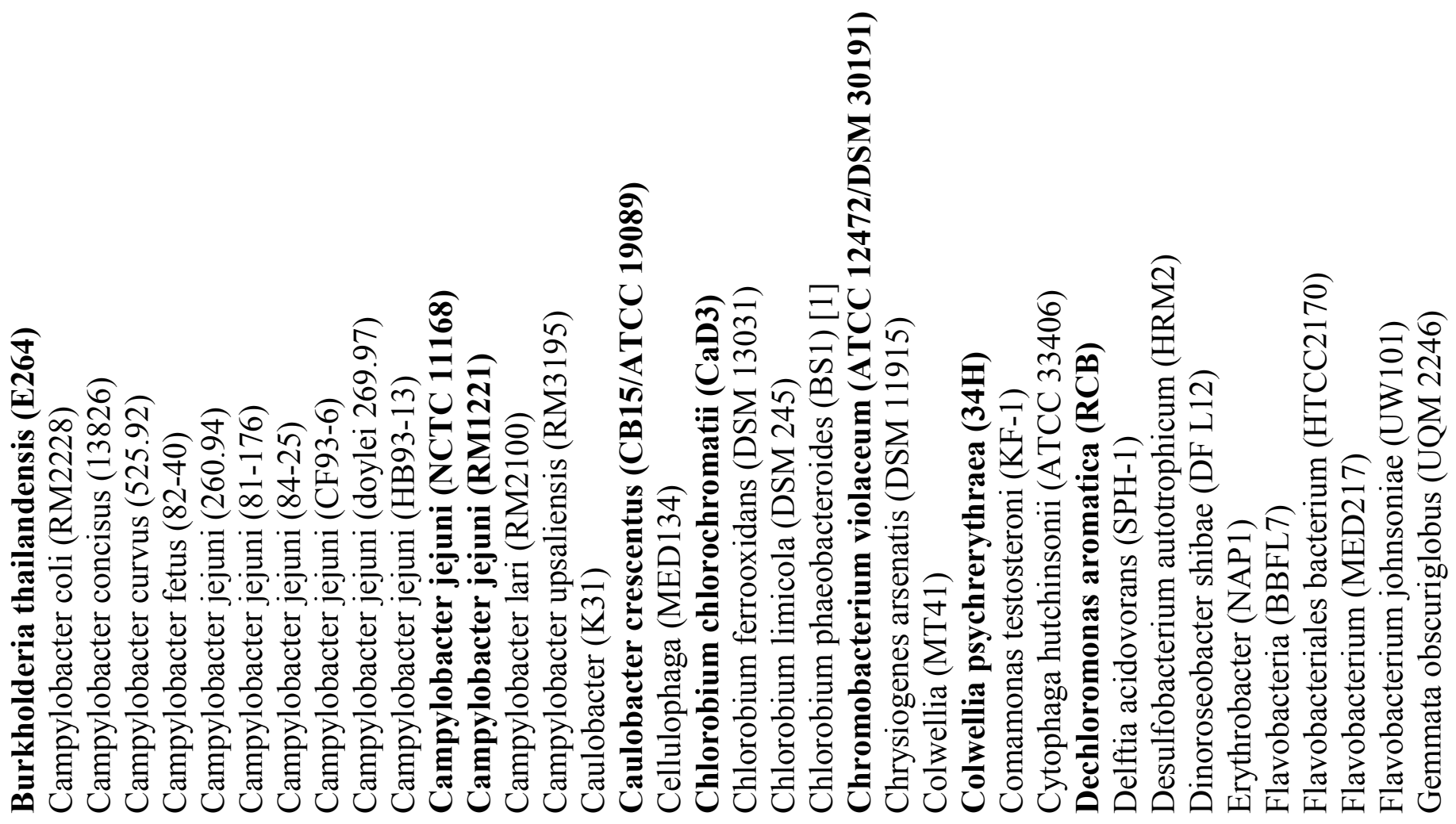




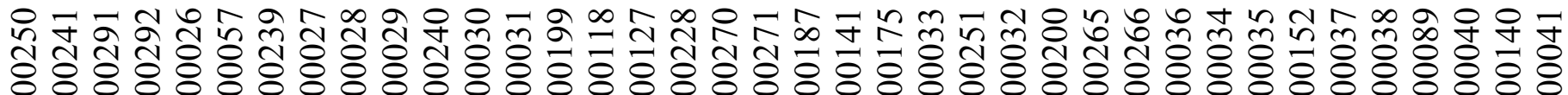
ป․

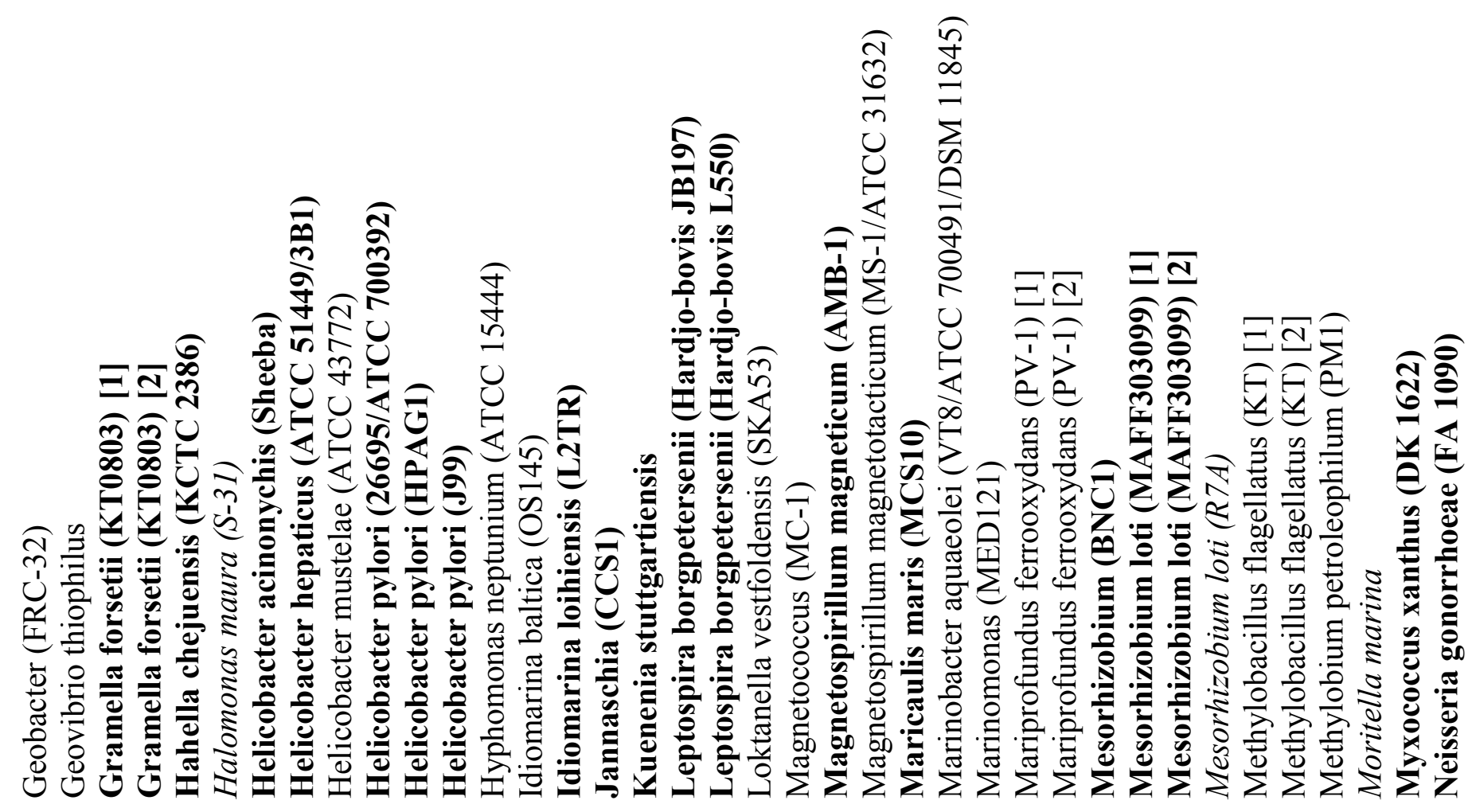




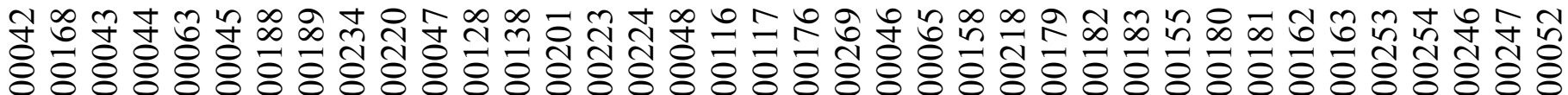

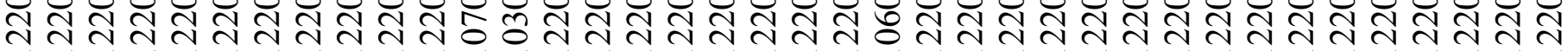

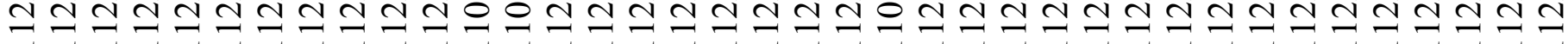

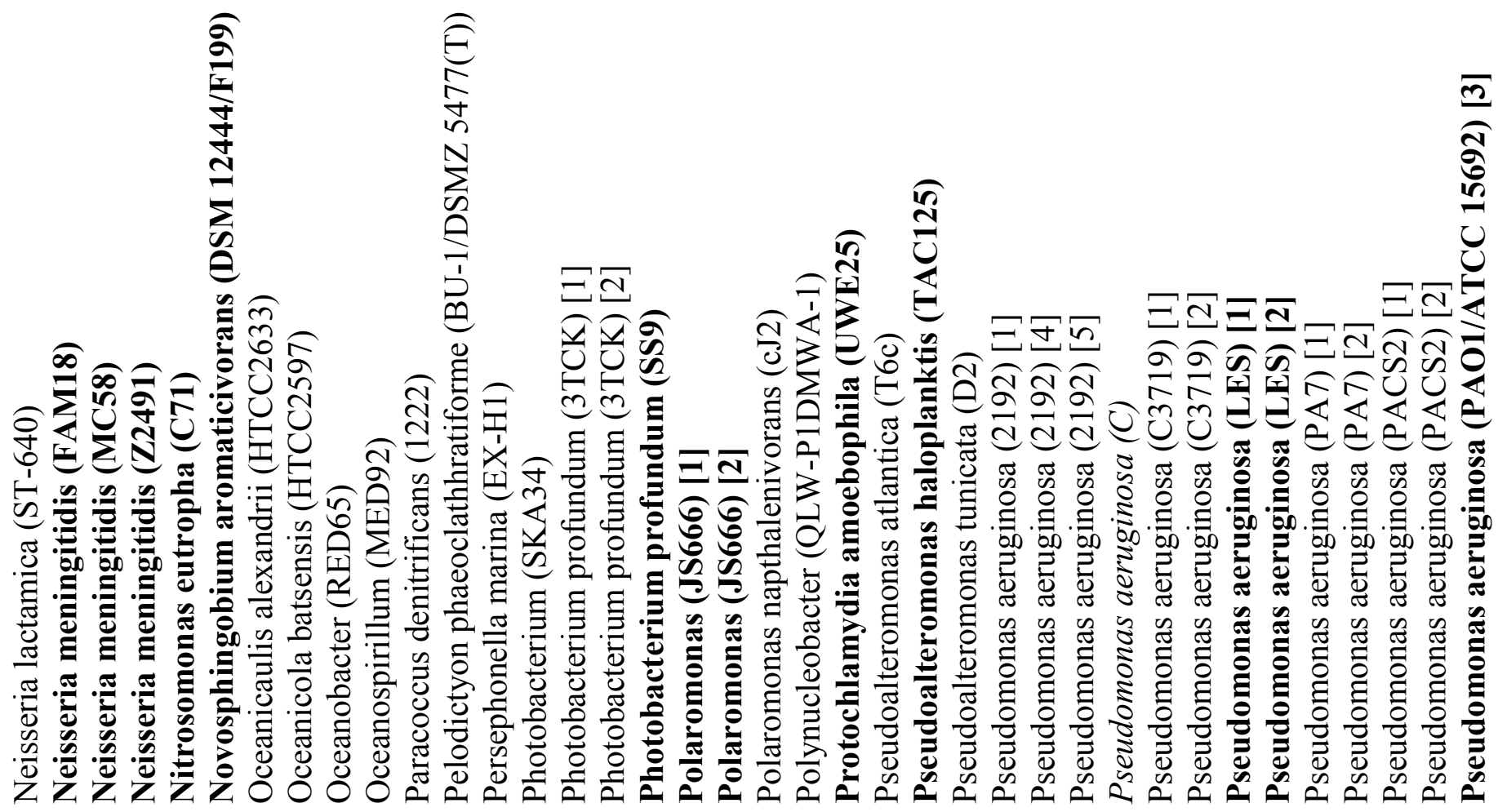




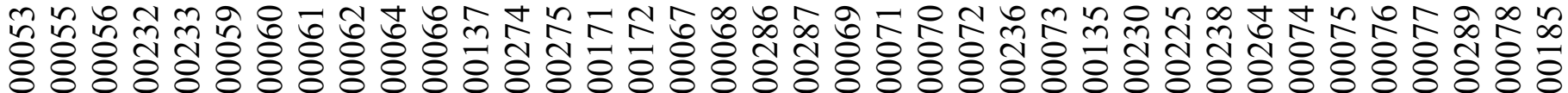

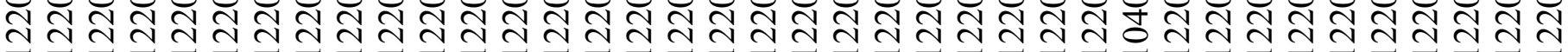

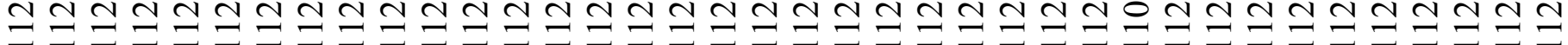

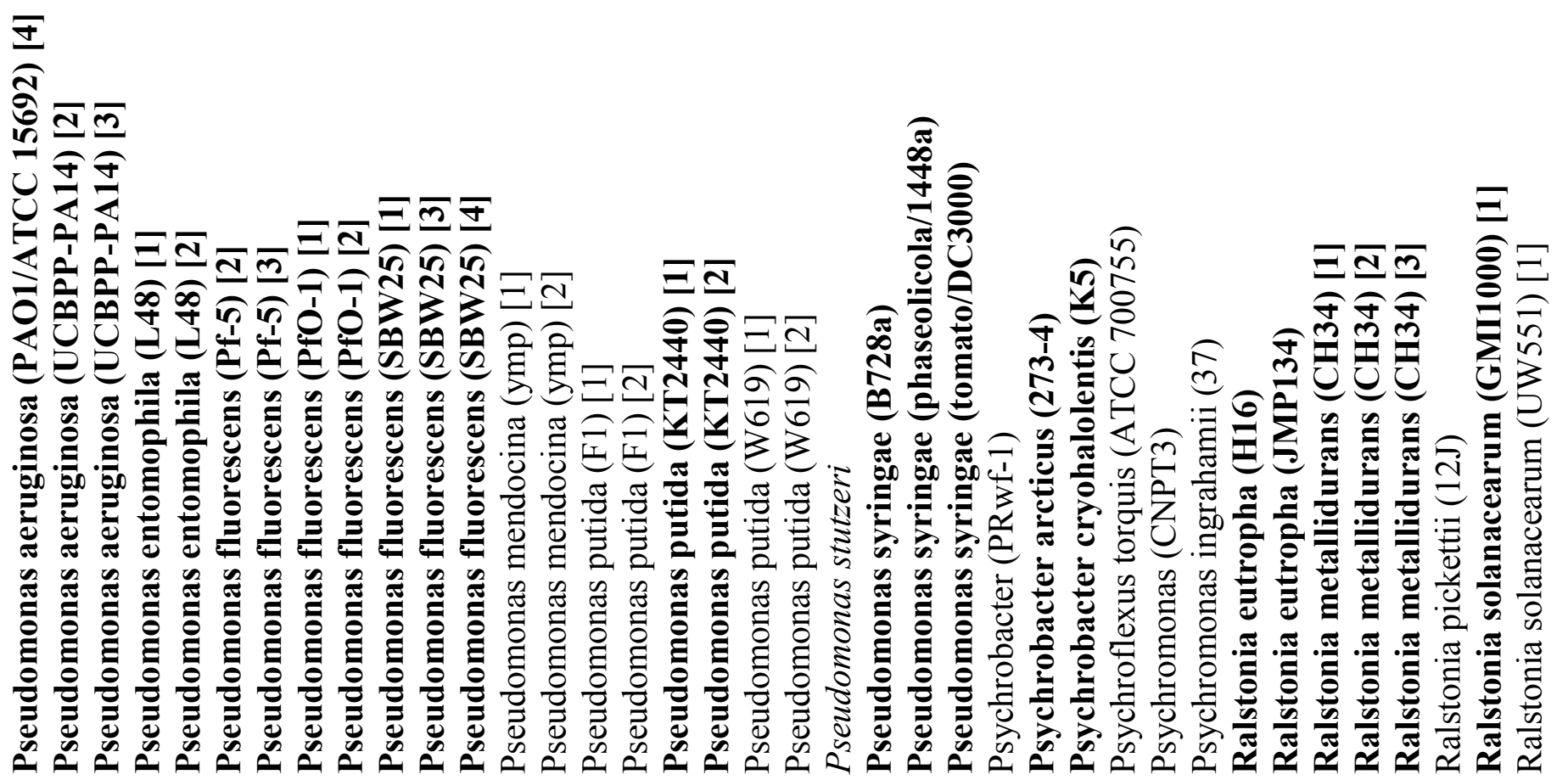


め)

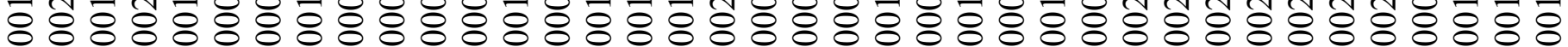

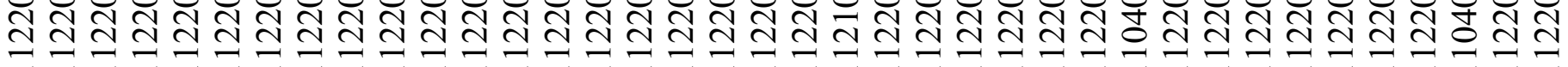

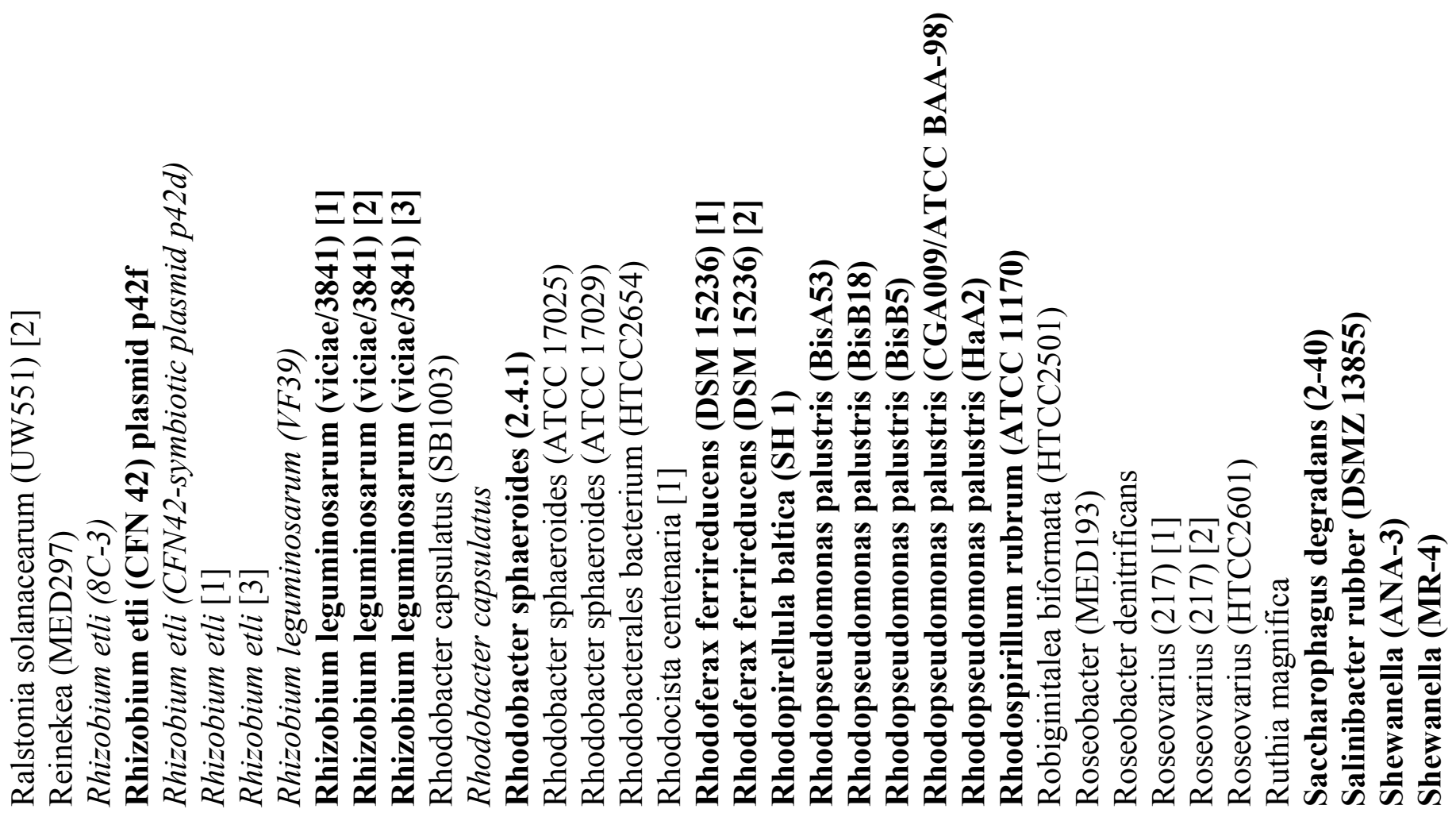


스술

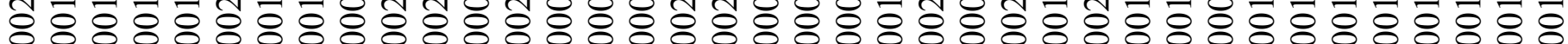
ปป ป ป ป ป ป ป ป ป ป ป ป ป ป ป ป

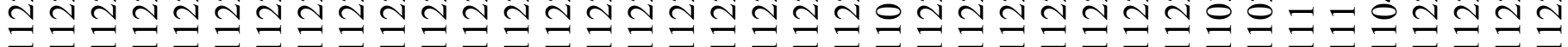

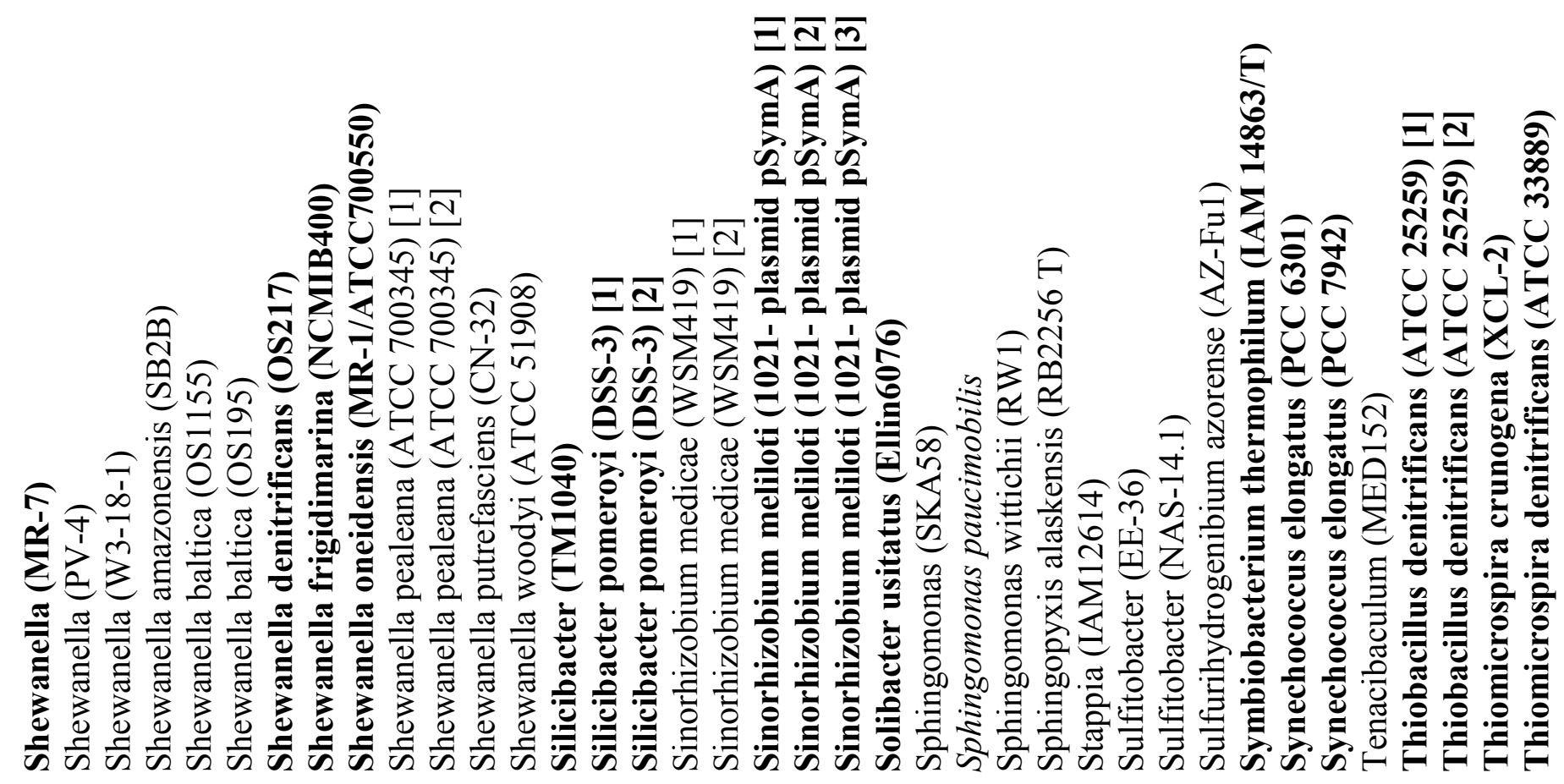




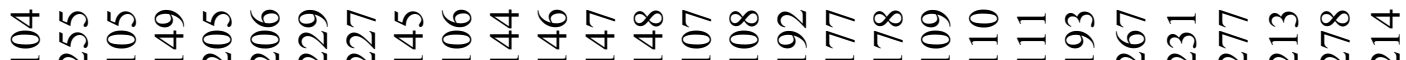

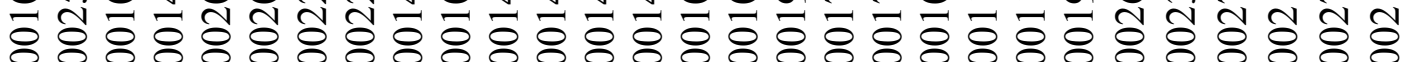
บ든

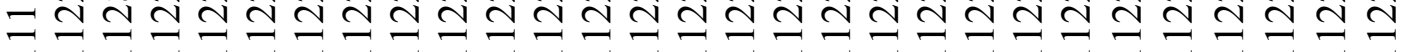
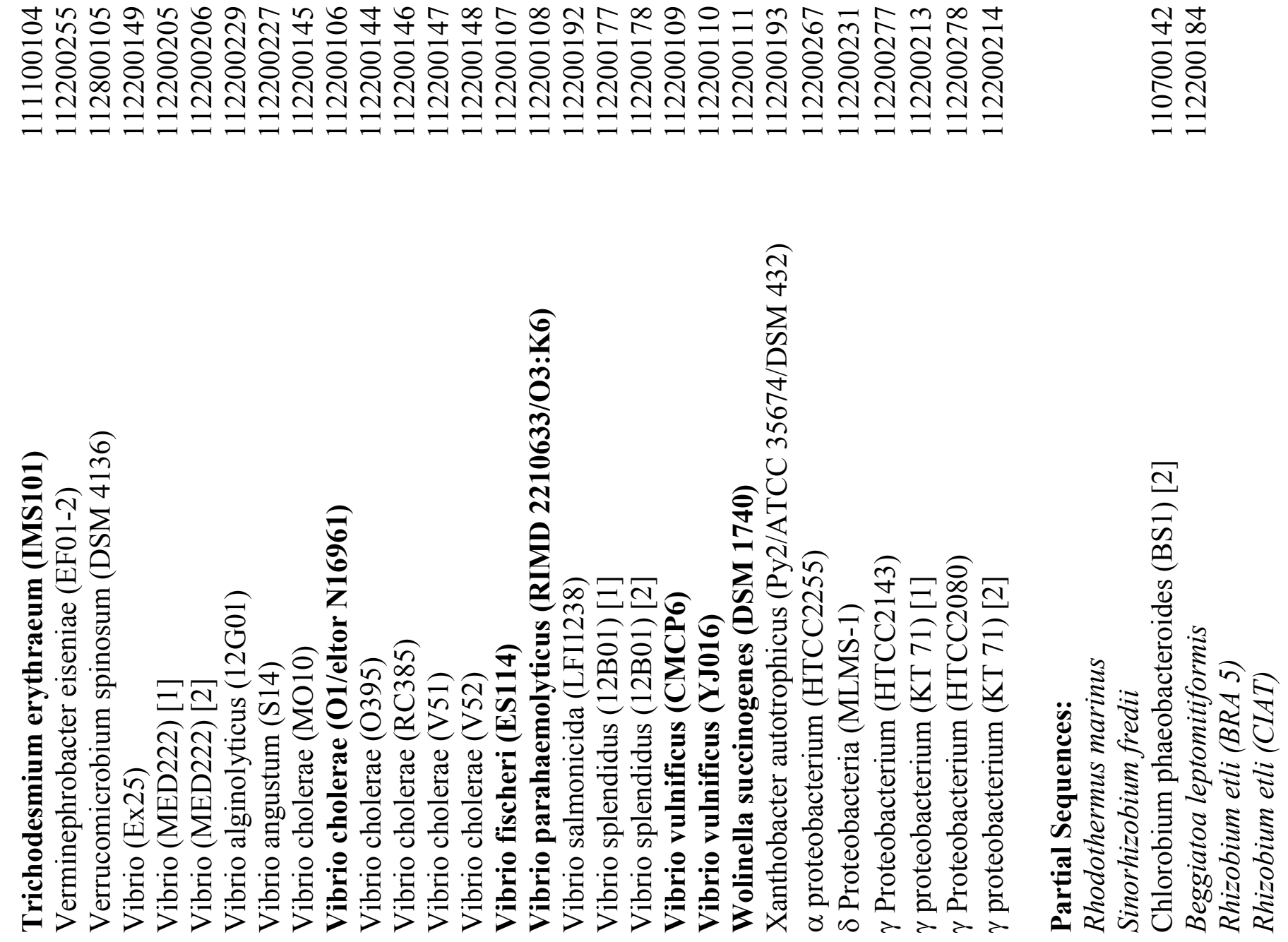


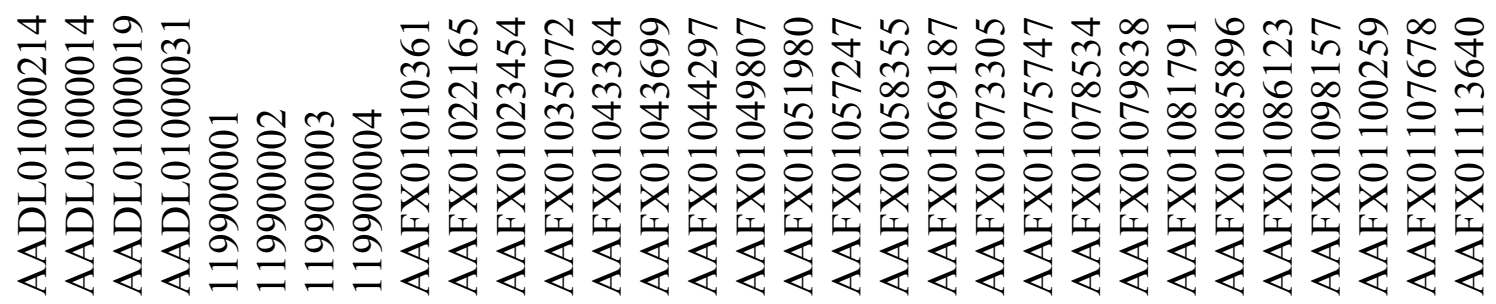

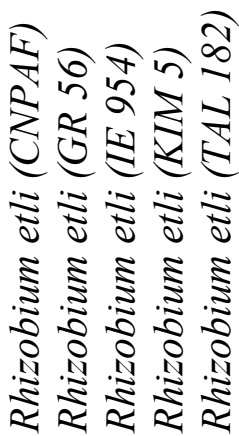

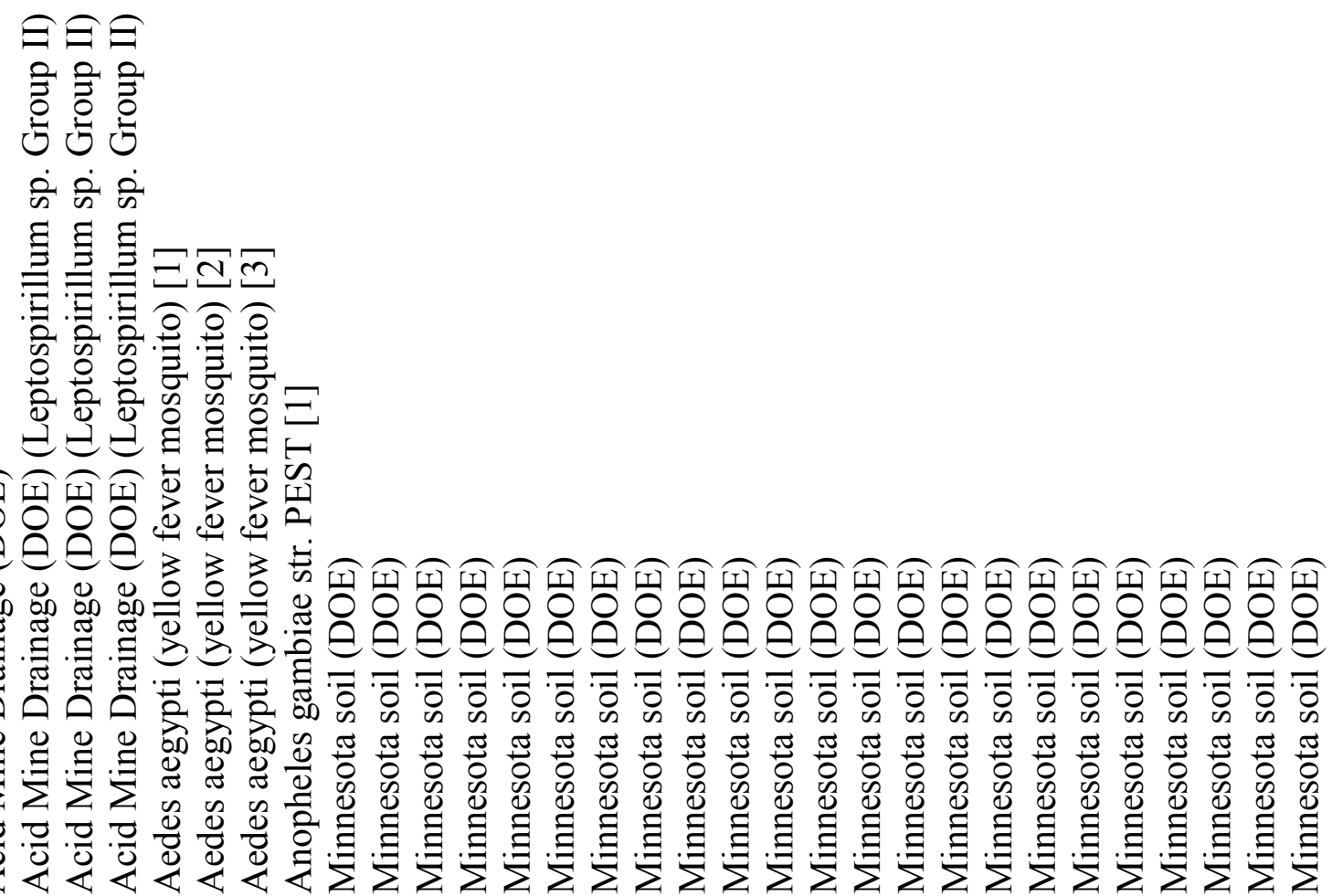



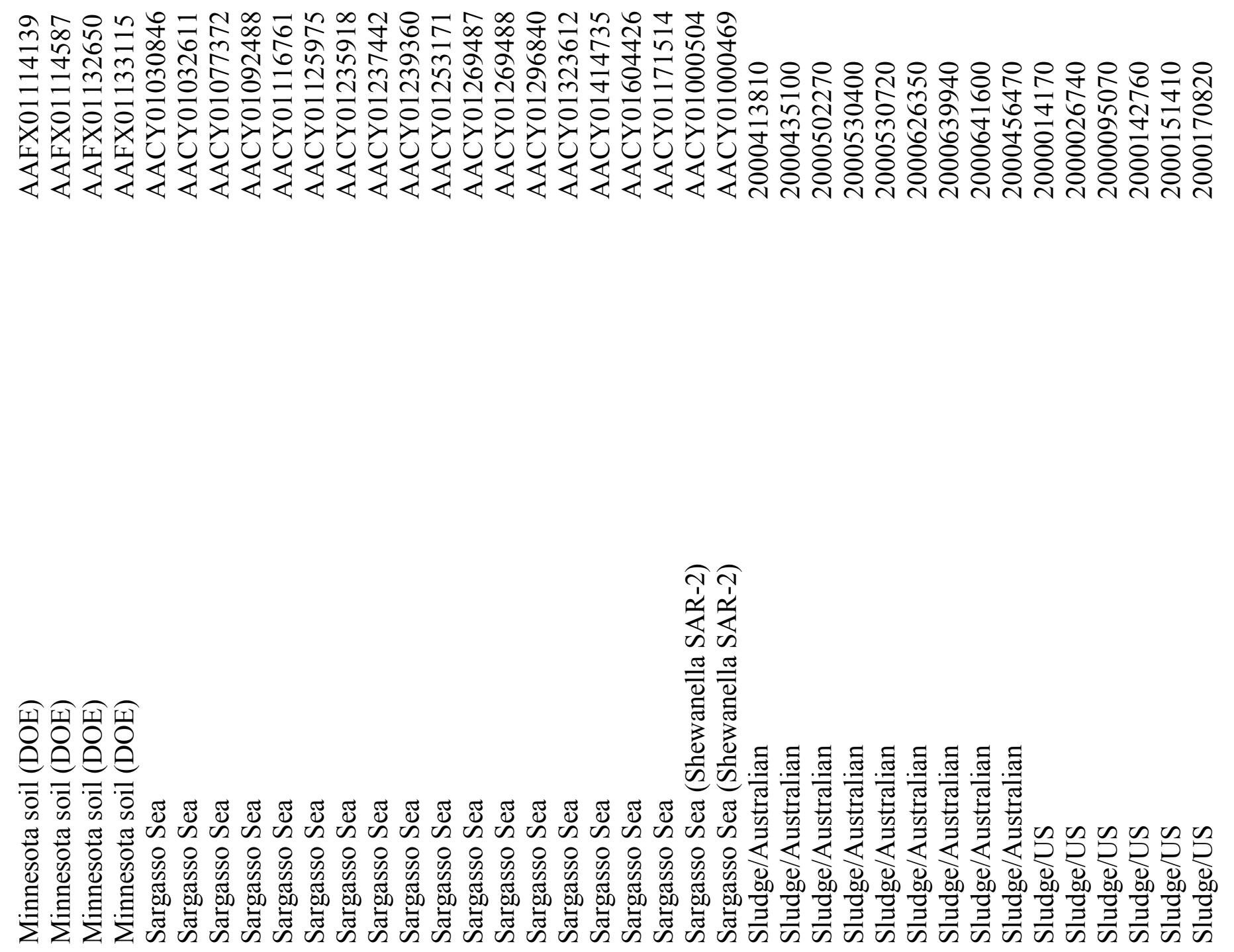


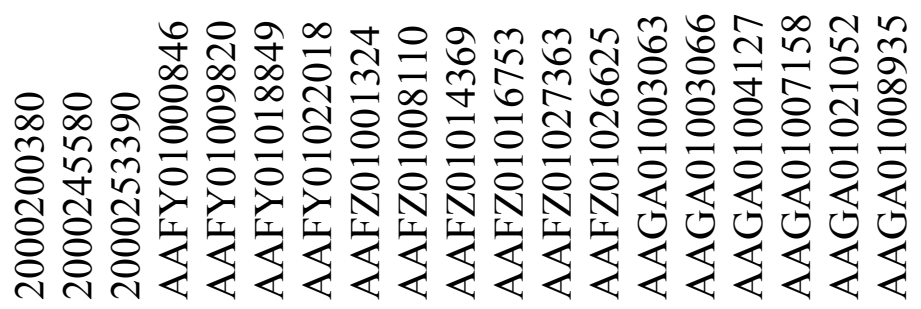

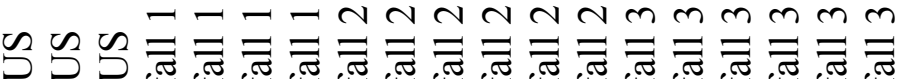
5.

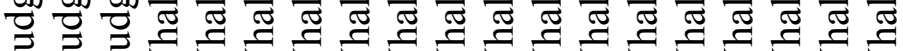

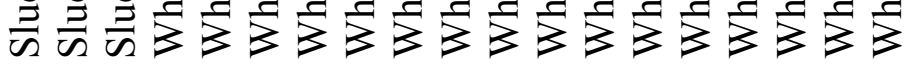

